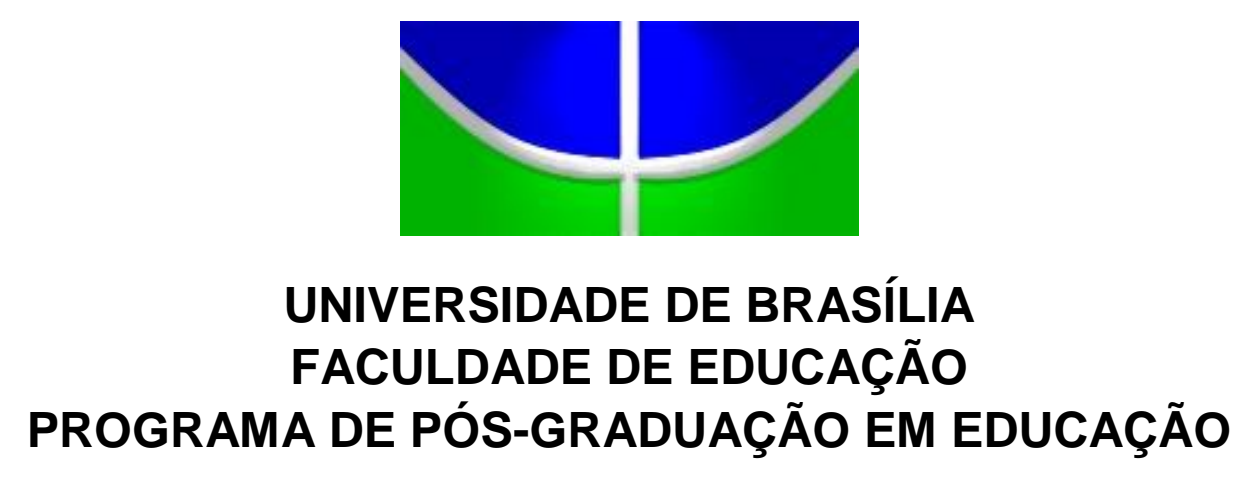

SAPATILHANDO NA BLOGOSFERA: Narrando o processo de subjetividade e pronunciamento feminino

Rita de Cácia Vieira Martins de Sousa

Brasília, DF

2016 


\section{UNIVERSIDADE DE BRASÍLIA \\ FACULDADE DE EDUCAÇÃO \\ PROGRAMA DE PÓS-GRADUAÇÃO EM EDUCAÇÃO}

Rita de Cácia Vieira Martins de Sousa

SAPATILHANDO NA BLOGOSFERA: Narrando o processo de subjetividade e pronunciamento feminino

Tese apresentada ao Programa de PósGraduação em Educação da Faculdade de Educação da Universidade de Brasília (UnB), como parte dos requisitos para a obtenção do título de Doutor em Educação e sob a orientação da Professora Dra. Teresa Cristina Siqueira Cerqueira. 


\title{
SAPATILHANDO NA BLOGOSFERA: Narrando o processo de subjetividade e pronunciamento feminino
}

\author{
Rita de Cácia Vieira Martins de Sousa
}

Tese defendida sob a avaliação da Comissão Examinadora constituída por:

Professora Dra. Teresa Cristina Siqueira Cerqueira (Presidente)

Programa de Pós-Graduação em Educação

Universidade de Brasília (UnB)

Professora Dra. Diva Maria Moraes A. Maciel (Membro Externo)

Programa de Pós-Graduação em Psicologia

Universidade de Brasília (UnB)

Professora Dra. Sinara Pollom Zardo (Membro Externo)

Programa de Pós-Graduação em Educação

Universidade Católica de Brasília (UCB)

Professora Dra. Cristina Massot Madeira Coelho (Membro)

Programa de Pós-Graduação em Educação

Universidade de Brasília (UnB)

Professora Dra. Vera Margarida Lessa Catalão (Membro)

Programa de Pós-Graduação em Educação

Universidade de Brasília (UnB)

Professor Dr. Paulo Sérgio de A. Bareicha (Membro Suplente)

Programa de Pós-Graduação em Educação

Universidade de Brasília (UnB)

Brasília (DF), 28 de março de 2016. 
50725 Sousa, Rita de Cácia Vieira Martins de

SS0725 SAPATILHANDO NA BLOGOSFERA: Narrando o processo

s de subjetividade e pronunciamento feminino / Rita de Cácia Vieira Martins de Sousa; orientador Teresa

Cristina Siqueira Cerqueira. -- Brasilia, 2016. 202 p.

Tese (Doutorado - Doutorado em Educação) -Universidade de Brasilia, 2016.

1. Subjetividade. 2. Círculos de cultura. 3. Pronunciamento feminino. 4. Hipertextualidade. I. Cerqueira, Teresa Cristina Siqueira, orient. II. Título. 


\section{DEDICATÓRIA}

À minha mãe, mulher de fala segura e vocabulário peculiar. Ao meu filho Rafael que me faz todos os dias exercitar o discurso e buscar conhecimentos sobre direitos humanos e questões de gênero. Ao meu filho Pedro que me incentiva a sempre fazer escolhas acertadas, mesmo que isso seja difícil.

Ao meu pai que me deu a vontade de nunca desistir: "ela não precisa de homens para guiá-la. Sabe se virar".

À minha orientadora que foi a bússola, a direção e meu exemplo para a toda a vida de que conseguimos produzir mesmo diante das adversidades.

À todas as mulheres que me ensinaram a pensar, agir e ser feminista na vida cotidiana e em todas as situações. 


\section{AGRADECIMENTOS}

Os quatro anos de duração dos estudos de Doutorado foram de tempestades e bonanças. E em todos esses momentos eu contei com pessoas que estiveram colaborando comigo.

Obrigada à minha banca de seleção, à minha banca de qualificação, banca examinadora e aos professores que direta ou indiretamente contribuíram com a minha formação.

À minha orientadora, amiga, parceira, cúmplice e incentivadora Teresa Cristina Siqueira Cerqueira, a grande mulher que assumiu a direção do meu trabalho, dando-me liberdade para pensar, escrever, argumentar e construir percursos.

Obrigada meus colegas de curso que escutaram meus ensaios e com os quais dividi bons momentos. GRUPPE (Grupo de Estudos e Pesquisas em Psicologia e Educação, coordenado pela professora Doutora Teresa Cristina Siqueira Cerqueira), valeu por tudo!!!

Obrigada minha amiga e irmã Norma que tanto me deu suporte e escuta na "reta final"! Obrigada mesmo. Nossas longas conversas foram meu oxigênio.

Obrigada Rafael pela leitura e escuta dos capítulos e sugestões para tornar meu texto mais claro e também pelas traduções do meu resumo. Filho, te amo!

Obrigada companheira Kátia Bordado por todas as vezes que você disse "vai estudar Rita" e que me incentivou a escrever. A escrita me salvou, tenha certeza disso!

Obrigada Joeanne Fraz pelo olhar atento na revisão das normas técnicas e pela delicadeza para me solicitar as devidas correções. 
No começo de minhas pesquisas sobre feminismo tive receio de conhecer as moças que admirava, me pareciam boas demais, politizadas demais, que pularam do ventre assim, formadas, contestadoras e seguras. Ao me aproximar o que comprovei é que feministas choram com poesia e gostam de histórias de amor, feministas sabem dar um soco e também sabem carinhar, costurar, cozinhar. Feministas se derretem ao ver filhotes de gato e adoram chocolate, feministas são livres para construir e desconstruir. Feministas também pisam na bola, podem ser insensíveis e tolher a liberdade alheia. Elas tem crise com o namorado que dá mancadas consideráveis, pode apostar. Há feminista que não consegue sair de casa sem maquiagem e feminista que gasta dinheiro com sapatos e bolsas. Desmistifique a feminista padrão que está no imaginário, não ame a liberdade de quebrar uma fôrma lustrando outra com tanto esmero.

Déborah Sá, 2012 


\section{RESUMO}

Esse é um estudo que se propôs a contribuir com a discussão sobre a produção da subjetividade feminina em hipertextos virtuais, reunidos sob a forma de diário eletrônico e como se constrói o processo interativo/educativo na relação autor/leitor nesta produção. Tivemos como objetivo geral, discutir a produção da subjetividade feminina e seu caráter interativo/educativo, em hipertextos e hipermídias virtuais, ancoradas em diário eletrônico, e em que medida esta produção colabora para o pronunciamento da cidadania da mulher. A partir desse norte centramos o estudo nos seguintes aspectos: refletir sobre as diversas linguagens midiáticas das postagens hipertextuais dos diários e os recursos discursivos empregados para favorecer o contar de si (autor) para o outro (leitor); analisar, nas narrativas confessionais postadas, os pronunciamentos da autoralleitores e sua finalidade no processo de subjetivação de ambos os polos; analisar os comentários das leitoras, tanto das postagens confessionais quanto de cunho político do diário, para entender a dimensão educativa/intersubjetiva construída nesse intercâmbio e finalmente, analisar a semiótica das camadas verbais, visuais e sonoras que constituem os hipertextos e suas possibilidades de expressão simbólica do pronunciamento da subjetividade feminina. Para sustentar esse exercício de interpretação, dialogamos com teorias e seus teóricos, em uma perspectiva de roda de conversa ou círculo de cultura, porque entendemos a construção do conhecimento enquanto diálogo entre círculos humanos e rizomáticos. Desta roda participaram Deleuze e Guattari discutindo o processo de subjetivação, Bakthin e Paulo Freire refletindo conosco sobre a dialogia, círculos de cultura e pronunciamento no ciberespaço e Levy e Santaella voltando nossas lentes para a dimensão hipertextual e simbólica das postagens do blog Sapatilhando, fenômeno sobre o qual nos debruçamos para entender seu fluxo. Cartografamos o fenômeno e nos cartografamos com ele, abrindo novos territórios, novas linhas de ruptura, revoluções moleculares que não nos levaram a conclusões, mas a expansões do movimento de leitura do mundo. Entendemos que o processo de constituição do ser humano, é uma presença no mundo, com o mundo e com os outros. Isto se dá quando trocamos vivências, relatamos nosso sentir e possibilitamos a dialogia. Com isso, instauramos um genuíno processo educativo na perspectiva freireana. Na fala cotidiana responsiva, pratica-se uma pedagogia da pergunta. Esta possibilidade se amplia com as novas tecnologias midiáticas que instauram uma estética do fluxo, em um trânsito contínuo, em um devir. Cada vez que a palavra constitui a identidade daquele que escreve, mais ele busca outras linguagens para comunicar de si, não usando as linguagens como ferramentas desprovidas de sentido e significado. Quando se age em rede, construindo rizomas, o ser humano, pode contribuir para a construção de uma cidadania onde todos usufruam, a partir do acesso aos bens culturais, de uma prática de questionar mais abertamente seu destino. Esta relação se dá porque a linguagem é uma atividade de construção de sentido e isto abre um amplo espaço para a ação educativa, onde a troca de saberes é uma construção em que o sentido das palavras é disputado, revisto e repensado.

Palavras-chave: Subjetividade. Círculos de cultura. Pronunciamento feminino. Hipertextualidade. 


\section{ABSTRACT}

This is a study that proposes to contribute with the discussion about the feminine subjectivity in virtual hypertexts, gathered in the form of electronic journals, and how the interactive/educational process is constructed in this production's author/reader relationship. We had as general objective discussing the production of feminine subjectivity and its interactive/educational character, in virtual hypertext and hypermedia, anchored in electronic journals, and in what measure this production colabora tes to the pronouncement of female citizenship. From this north we have centered the study in the following aspects: reflecting upon the diverse media languages found in the journal's hypertextual posts and the discursive resources employed to favor the telling of oneself ( author) to the other ( reader); analyzing, in the confessional narratives posted, the pronouncements of the author/readers and their purposes in the process of subjectivation of both poles; analyzing the readers comments, in both the confessional and the politically driven posts in the journal, to understand the educational/intersubjective dimension built in this interchange; and, finally, analyzing the semiotic of the verbal, visual and sound layers that compose the hypertext and their simbolic expression possibilities in the feminine subjectivity pronouncement. In order to sustain this interpretation exercise, we have established a dialog with theories and their authors, in a circle of talk/culture perspective, because we understand the construction of knowledge as a dialog between human and rhizomatic circles. Composing this circle we had Deleuze and Guattari discussing the process of subjectivation, Bakthin and Paulo Freire reflecting with us upon dialogy, culture circles and cyberspace pronouncement and Levy and Santaella turning the focus of our lenses to the simbolic and hypertextual dimension of the postings in the blog Sapatilhando, a phenomenon upon which we have laid our eyes to understand its flow. To this reading I have constructed cartographic strategies, fundamented in the studies of Deleuze and Guattari. We have mapped the phenomenon and we have been mapped by it, opening new territories, new lines of rupture, molecular revolutions that lead us not to conclusions, but to expansions in the motion of world reading. We have understood that the process of human constitution is a presence of the world, with the world and with the others. That takes place when we exchange, tell our feelings and allow dialogy. With that, we have built a genuine educational process in the Freirean perspective. In the responsive daily talk, a question pedagogy is practiced. This possibility is broadened by the new midiatic Technologies that have instaured the flux aesthetics, in a continuous flow, in a devenire. Each time that the word constitutes the identity of the one that writes, more he searches other languages to comunicate of himself, not using the languages as tools unarmed of sense and meaning. When one acts in network, building rhizomes, the human being can contribute to the construction of a citizenship of which all can benefit, of acess to cultural assets, of a practice of questioning their destiny more openly. This relationship takes place because the language is an activity defined by construction of meaning and that opens a wide space to educative action, where the exchange of knowledge is a construction in which the meaning of the words is disputed, revised and rethought. 


\section{RESUMEN}

Se trata de un estudio que tuvo como objetivo contribuir a la discusión sobre la producción de la subjetividad femenina en hipertextos virtuales, reunidos en forma de diario electrónico, y sobre cómo se construye el proceso interactivo/educativo en la relación autor/lector en esta producción. Tuvimos como objetivo principal discutir la producción de la subjetividad femenina y su naturaleza interactiva/educativa, en hipertextos e hipermedios virtuales anclados en diario electrónico, y también observar en qué medida esta producción contribuye a la enunciación de la ciudadanía de las mujeres. A partir de este norte, nos centramos en el estudio de los siguientes elementos: reflexionar acerca de los diversos lenguajes de la comunicación de mensajes hipertextuales de los diarios y los recursos discursivos empleados para fomentar el contar de sí (autor) al otro (lector); analizar, en los relatos confesionales publicados, las enunciaciones de la autora/las lectoras y su propósito en el proceso subjetivo de los dos polos ; analizar los comentarios de las lectoras, tanto en las publicaciones confesionales como en las de naturaleza política del diario, de modo a entender la dimensión educativa/intersubjetiva construida por medio de este intercambio; y, finalmente, analizar la semiótica de capas verbales, visuales y de audio que componen el hipertexto y sus posibilidades de expresión simbólica en la enunciación de la subjetividad femenina. Para apoyar este ejercicio de interpretación, dialogamos con las teorías y con los que las propusieron, en la perspectiva de la rueda de conversación o círculo de cultura, porque entendemos la construcción del conocimiento como el diálogo entre los humanos y los círculos rizomáticos. En esta rueda participaron Deleuze y Guattari con la discusión acerca del proceso de la subjetivación; Bakthin y Paulo Freire reflexionaron con nosotros sobre dialogismo, círculos de cultura y de expresión en el ciberespacio; y Levy y Santaella nos hicieron volcar nuestras lentes de dimensión hipertextual y simbólica hacia las publicaciones del blog Sapatilhandos, fenómeno sobre el que nos asomamos a fin de entender su flujo. Cartografiamos el fenómeno y nos cartografiamos con él, de modo a engendrar nuevos territorios, nuevas líneas de ruptura, revoluciones moleculares que no nos llevaron a conclusiones, sino a expansiones del movimiento de lectura de mundo. Entendemos que el proceso de constitución del ser humano es una presencia en el mundo, con el mundo y con los demás. Ello se produce cuando intercambiamos vivencias, expresamos nuestro sentir y posibilitamos la dialogía. De esa forma, establecemos un auténtico proceso educativo en la perspectiva de Freire. En el habla cotidiana sensible, se practica una pedagogía de la pregunta. Esta posibilidad se amplifica con las nuevas tecnologías mediáticas que plantean una estética del flujo, en un tráfico continuo, en un devenir. Cada vez que la palabra constituye la identidad del que escribe, más ese busca otros lenguajes para hablar de sí, sin que se utilicen los lenguajes como herramientas desprovistas de sentido y significado. Cuando se actúa en red, construyendo rizomas, el ser humano puede contribuir a la construcción de una ciudadanía donde todos disfruten, desde el acceso a los bienes culturales, de una práctica de cuestionar de forma más abierta su propio sino. Esta relación se da porque el lenguaje es una actividad de construcción de sentido y esto abre un amplio espacio para la acción educativa, donde el intercambio de saberes es una construcción en que el sentido de las palabras se disputa, se revisa y se repiensa.

Palabras clave: subjetividad. Círculos de cultura. Enunciación femenina. hipertextualidad 


\section{LISTA DE ABREVIATURAS E SIGLAS}

$\begin{array}{ll}\text { AMB } & \text { Articulação de Mulheres Brasileiras } \\ \text { ANPEd } & \text { Associação Nacional de Pesquisa em Educação } \\ \text { ANPOCS } & \text { Associação Nacional de Pós-Graduação e Pesquisa em Ciências } \\ \text { CAPES } & \text { Sociais } \\ \text { CBEs } & \text { Coordenação de Aperfeiçoamento de Pessoal de Nível Superior } \\ \text { CEAD-UnB } & \text { Conferências Brasileiras de Educação } \\ \text { CESPE } & \text { Centro de Educação a Distância da Universidade de Brasília } \\ \text { ECA } & \text { Centro de Seleção e de Promoção de Eventos } \\ \text { IPEA } & \text { Estatuto da Criança e do Adolescente } \\ \text { LDBEN } & \text { Instituto de Pesquisa Econômica Aplicada } \\ \text { MCP } & \text { Lei de Diretrizes e Bases da Educação Nacional } \\ \text { MEB } & \text { Movimento de Cultura Popular } \\ \text { MEC } & \text { Ministério da Educação } \\ \text { LOAS } & \text { Lei Orgânica de Assistência Social } \\ \text { OEA } & \text { Organização dos Estados Americanos } \\ \text { ONGs } & \text { Organizaçães Não-Governamentais } \\ \text { ONU } & \text { Organização das Naçães Unidas } \\ \text { PT } & \text { Partido dos Trabalhadores } \\ \text { PUC-SP } & \text { Pontifícia Universidade Católica de São Paulo } \\ \text { SBPC } & \text { Sociedade Brasileira para o Progresso da Ciência } \\ \text { SBS } & \text { Sociedade Brasileira de Sociologia } \\ \text { UnB } & \text { Universidade de Brasília } \\ \text { UNESCO } & \text { Organização das Nações Unidas para Educação, Ciência e } \\ & \text { Cultura }\end{array}$




\section{LISTA DE FIGURAS}

Figura 1 - BLOG Climatério etério ………...................................................19

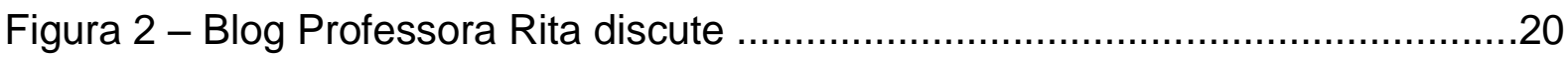

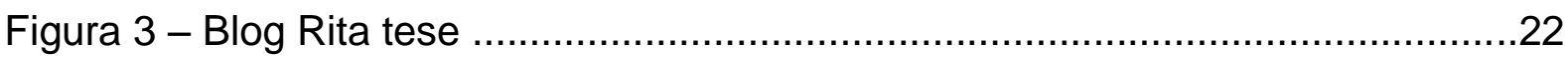

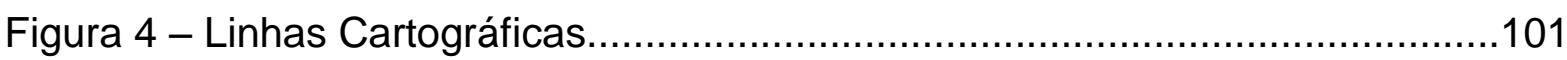

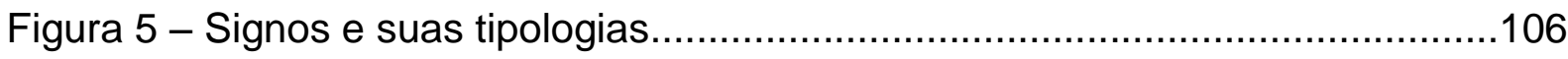

Figura 6 - Identidade visual/Banner do blog.................................................109

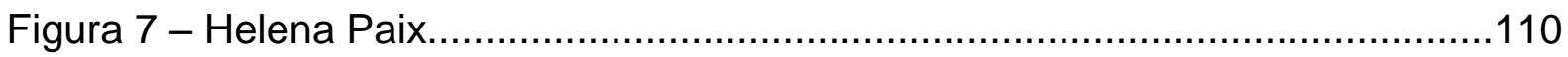

Figura 8 - Personagem e signo - Helena Paix.................................................116

Figura 9 - Carta aos pais da autora de Sapatilhando...........................................122 


\section{SUMÁRIO}

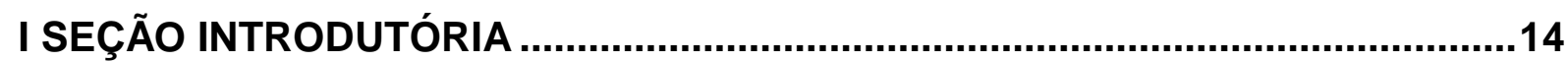

1.1 INTRODUÇÃO

II SEÇÃO TEÓRICO-METODOLÓGICA

CAPÍTULO 2.1 EDUCANDO PARA ALÉM DOS MUROS DA ESCOLA - OS MOVIMENTOS DA SOCIEDADE E SEUS MOVIMENTOS .......................................29

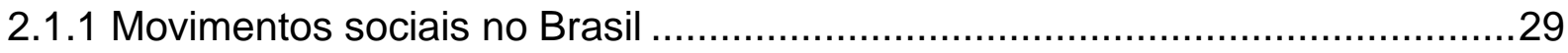

2.1.2 Movimento de mulheres no Brasil ...........................................................33

2.1.3 O movimento de mulheres como um fazer educativo ....................................39

CAPÍTULO 2.2 A TRAMA DE FIOS TEÓRICOS E OLHARES PARA TECER MEU

TAPETE

2.2.1 A teoria da subjetividade de Guattari - do sujeito e suas revoluções ...............45

2.2.1.1 A produção da subjetividade ........................................................... 48

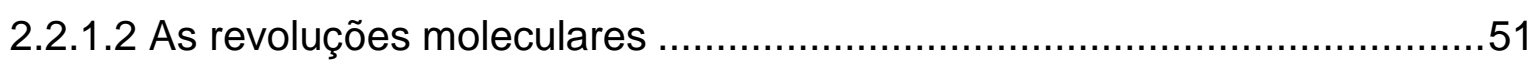

2.2.2 O Círculo de Bakhtin - a dialogia como processo educativo....................53

2.2.2.1 O Círculo bakhtiniano - a concepção de linguagem ................................54

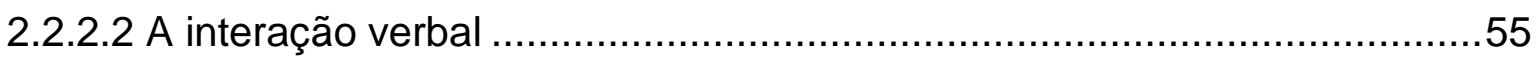

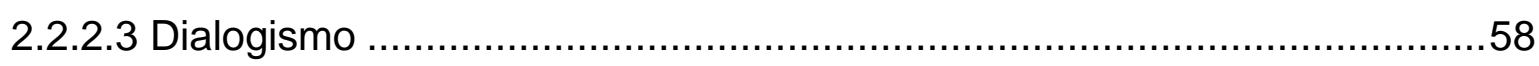

2.2.3 As teorias de Levy e Santaella - cartografando novos territórios e novas linhas 64

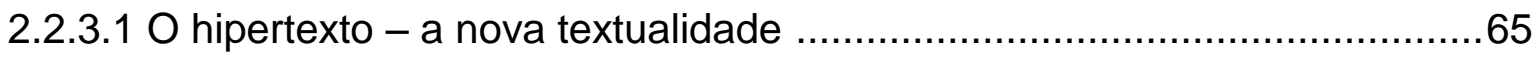

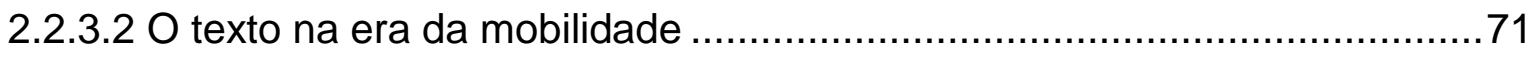

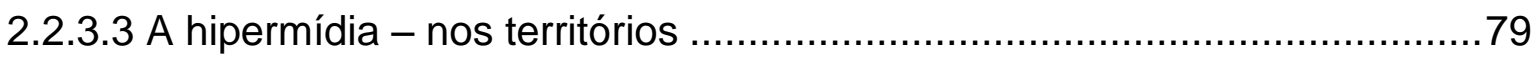

2.2.4 Blogosfera como círculo de cultura - uma leitura do pronunciamento feminino,

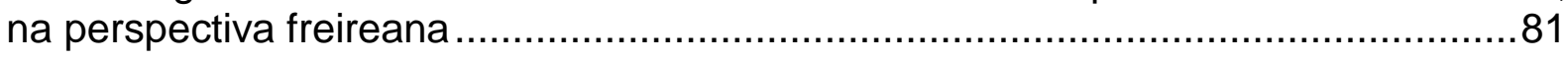

2.2.4.1 O Círculo de cultura - a educação para a liberdade ................................ 85

2.2.4.2 O pronunciamento, na perspectiva freireana ............................................ 89 
III SEÇÃO CONSTRUTIVA - INTERPRETATIVA ...............................................107

CAPÍTULO 3.1 SAPATILHANDO - A CARTOGRAFIA.....................................108

3.1.1 Helena Paix - uma subjetividade pulsante ..............................................109

3.1.2 Três platôs - três idades - o percurso da borboleta .....................................132

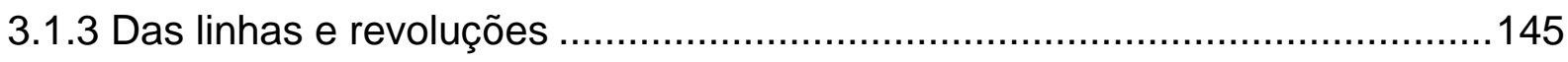

3.1.4 Sapatilhando e seus círculos em movimento .........................................155

IV CONCLUSÕES E EXPANSÃO DOS CíRCULOS ...........................................165

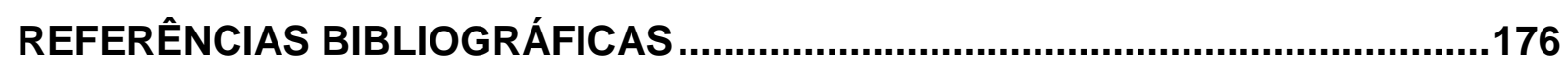

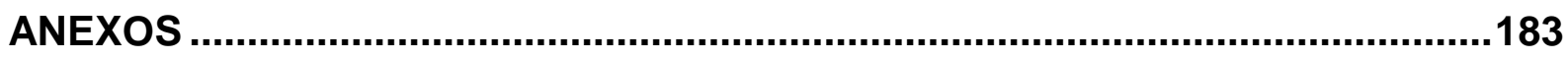


I SEÇÃO INTRODUTÓRIA 


\title{
1.1 INTRODUÇÃO
}

\begin{abstract}
Então escrever é o modo de quem tem a palavra como isca: a palavra pescando o que não é palavra. Quando essa não-palavra morde a isca, alguma coisa se escreveu. Uma vez que se pescou a entrelinha, podia-se com alívio jogar a palavra fora. Mas aí, cessa a analogia: a não-palavra ao morder a isca, incorporou-a. O que salva então é ler distraidamente.
\end{abstract}

Clarice Lispector

Cresci cercada de mulheres contadoras de histórias. Avós, tias e empregadas. Bebia cada passagem desses textos orais e com eles ergui cidades, construí estradas e cavalguei por extensos campos de areia e rodopiei com o vento. Desde muito cedo, estava selado meu destino com a linguagem. As palavras continuaram me tomando pelas mãos quando tatuadas também nas páginas dos livros.

O rodopio com o vento trouxe para minha identidade a marca ancestral da matriz africana, o ritmo da minha bisavó dançando em círculo seus sambas de roda no terreiro da fazenda, abrindo a saia nos abraçava e nos colocava ao centro. Ali aprendi que os orixás eram força e vida. Ali com ela aprendi a magia das ervas e das benzeduras das pretas-velhas, dos caboclos e o poder das novenas. Com ela e com minha avó materna soube o valor do abraço da cura, dos banhos de descarrego e das beberagens que abriam a mente para enxergar melhor o caminho. Até hoje ouço vivamente o sorriso delas quando me abraçavam e contavam histórias sem fim de tempos imemoriais, eivadas de ensinamentos ancestrais. Por conta delas, ler Guimarães Rosa era trazê-las de volta ao presente.

Nada me atraía mais na adolescência que o quartinho estreito e iluminado por uma claraboia onde uma tia idosa guardava caixas de livros antigos. Foram tardes e mais tardes de viagens por estas páginas que cheiravam a tempo vivido. Com esse contato, a oralidade (lia em voz alta para mim mesma), a escrita e a imagem se tornaram indissociáveis. Tive noção do estar no mundo quando abri obras literárias, foram inicialmente 35 Janelas para o Mundo ${ }^{1}$, depois vieram as mais

\footnotetext{
${ }^{1}$ Livro publicado em 1960 pela Editora Seleções do Readers Digest.
} 
intensas experiências de fruição. Os textos tomaram minha vida e escolhi, daí em diante, todos os caminhos onde eles estivessem presentes.

$\mathrm{Na}$ adulteza me fiz educadora, acreditando no papel político desta escolha. Sou daquelas mulheres que não dispensa uma roda de conversa, uma contação de histórias e causos, porque são desses movimentos da linguagem e do humano que o processo educativo verdadeiro se alimenta.

Sou educadora desde 1986, com graduação em Letras, Especialização em Literatura e Mestrado em Educação. Desse início até o ano de 2008, atuei em sala de aula, nas diversas modalidades de ensino oferecidas pela rede pública do Distrito Federal. Essa experiência me proporcionou ter contato com os mais variados segmentos sociais, sendo este um fator determinante de enriquecimento pessoal, matéria prima indispensável na minha identidade política e no engajamento cotidiano na luta por uma escola pública de qualidade para todos.

Concomitante a este trabalho, atuo como docente do ensino superior na modalidade presencial e na modalidade a distância, desde 1990.

Com meus alunos adolescentes, aprendentes como eu, troquei desejos, olhares, procurei respostas e aprendi a desconstruir o constituído e me fazer projeto em construção, em eterno inacabamento. Dessa prática, nasceram meus cadernos e cadernetas de notas esparsas, onde registro o que sinto e o que anseio, tanto como mulher quanto como educadora. São duas faces indissociáveis.

A atividade docente por sua vez, não me impossibilitou de vivenciar outras funções no sistema educativo local, passando pelas áreas administrativas, de assessoramento e de coordenação pedagógica. Posso hoje afirmar que conheço a rede pública de ensino do DF, tanto em uma perspectiva macro quanto micro organizacional.

Paralelo à prática docente, desenvolvi atividades de assessoria a grupos feministas e a parlamentares (Assembleia Constituinte de 1988) quando da minha passagem pelo Conselho Nacional dos Direitos da Mulher na década de 1990 e a militância propriamente dita nos dias atuais no Núcleo de Mulheres do grupo Estruturação e no Fórum de Mulheres do Distrito Federal. Com estas experiências, tomei contato com a militância feminista nas redes sociais e a partir dela, fui delegada pelo Distrito Federal na IV Conferência dos Direitos das Mulheres que 
ocorreu em Brasília (2012) e coordenei a delegação de mulheres do Distrito Federal que participou da Cúpula dos Povos no Rio de Janeiro no mesmo ano. Em 2015 fui eleita delegada pelo Distrito Federal à IV Conferência Nacional dos Direitos das Mulheres a ser realizada em março do corrente ano.

Institucionalmente atuo como representante da Secretaria de Educação no Conselho da Juventude do Distrito Federal, no Comitê contra a intolerância religiosa e na Comissão Distrital de construção da Base Nacional Comum Curricular. Funções que abracei por identidade com as temáticas e por serem espaços nos quais o diálogo e a construção coletiva são a tônica.

A militância por uma escola pública laica e de qualidade para os brasileiros e a luta pela garantia dos direitos das mulheres são fios de uma mesma trama na construção no meu percurso político, profissional e na construção da minha subjetividade. Sou mulher, mãe, feminista e educadora com a mesma intensidade, compromisso e paixão.

Desde 2004 venho também trabalhando como tutora, orientadora, autora e gestora de cursos a distância voltados para a formação de professores/servidores públicos em níveis de Extensão, Graduação e Especialização junto à Universidade de Brasília (CEAD-UnB; CESPE), à Universidade Católica Virtual de Brasília e mais recentemente na Universidade Livre Feminista, na Universidade Federal do Ceará e na Escola de Governo do Distrito Federal.

Em função desse contato constante com o ciberespaço para fins pedagógicos, trabalho nos últimos anos com ferramentas virtuais interativas, como é o caso de blogs para a elaboração de memoriais de aprendizagem e também com ambientes virtuais de aprendizagem (plataformas TelEduc e Moodle). Com estas ferramentas vi, ouvi e me deslumbrei com as trocas de experiências, de emoções e de histórias humanas ganhando novos sentidos.

Com as novas tecnologias de informação e comunicação, essas trocas se tornaram muito ricas, na dialogia dos fóruns assíncronos, na construção de textos colaborativos em wikis, em diários de bordo, portifólios eletrônicos e memoriais de formação. Era o início da exploração de hipertextos e hipermídias. Os suportes eletrônicos abrindo uma gama de possibilidades para ampliar o foco de visão do mundo e novos sentidos para o que era vivenciado. O mundo começava a ter sentido em rizomas e redes, constituindo-se em uma textualidade infinita. Textualidade que se fazia minha também. 
O ciberespaço se constituiu para mim como um universo no qual eu podia me ver e ser vista. Eu podia me identificar com uma infinidade de mulheres, de pessoas que de alguma forma sentiam a vida de modo semelhante ao meu.

Eu era naquele momento quando do contato com o blog Sapatilhando ${ }^{2}$, sobre o qual reflito neste estudo, uma mulher entrando nos 50 anos, estranhando o próprio corpo e suas emoções. Uma mulher que buscava respostas para suas inquietações e que tentava trazer à luz as sombras que a atormentavam. Era uma mulher buscando a si mesma como mãe, como ser humano feminino, questionando sua identidade de gênero, na complexidade que isto significava. Como Helena, a autora do blog, eu me debatia entre o dizer e o não dizer de mim. Como Helena, eu estava Sapatilhando uma nova coreografia, um novo ritmo.

Passei, em paralelo a essas descobertas, a pertencer a comunidades virtuais, tornei-me um texto que se constitui narrando e lendo narrativas de outros eus. De rede em rede cheguei à blogosfera - comunidade heterogênea habitada virtualmente pelos mais variados matizes. Meu olhar, entretanto, por conta das minhas configurações subjetivas, voltou-se em zoom para o matiz feminista e para a prática militante da blogagem coletiva e pontual, uma ação possível de forma rápida e em um curto espaço de tempo. O hipertexto tremulando como bandeira de luta no Portal Blogueiras Feministas. Para este grupo, blogar é sinônimo de contestação e unir forças para dar voz às minorias políticas, em uma ação de postar simultaneamente na rede suas opiniões provocando um efeito cascata que faça a discussão da defesa dos direitos das mulheres ressoar em todos os cantos do ciberespaço.

No conjunto deste portal, me ative no blog Sapatilhandoe desde 2011 venho acompanhando as postagens deste diário eletrônico, as manifestações autorais de Helena Paix e os diversos comentários das suas seguidoras. Blog autoral entre outras ferramentas da autora (Facebook, Tumblr, witter, site) para exercer sua militância político-existencial diante da discussão de gênero, em específico o tema da lesbianidade e homoafetividade.

O contato com os diários eletrônicos também repercutiu no trabalho como tutora de cursos à distância para a formação de professores, tanta na formação inicial quanto em cursos latu sensu ofertados em plataformas virtuais. Durante o

\footnotetext{
${ }^{2}$ Endereço eletrônico: http://www.sapatilhando.com.br/
} 
desenvolvimento das disciplinas para uma aproximação mais cuidadosa da teoria com a prática, com a história de cada aluno, lançou-se mão da ferramenta blog para ancorar diários de bordo do processo de construção do futuro docente ou refletir sobre a formação continuada de outros gestores.

Escrever diários (blogar) eletrônicos e trocar vivências com o suporte das novas tecnologias de informação e comunicação tornou-se algo imprescindível, tanto na minha militância feminista quanto na minha prática educativa. Dessa necessidade adveio dois blogs de minha autoria, em um deles meu perfil é de educadora e no outro o perfil é da mulher que sou, vivenciando o portal de meio século, e deste lugar falo das agruras e gostosuras do envelhecer:

Figura 1 - BLOG Climatério etéreo

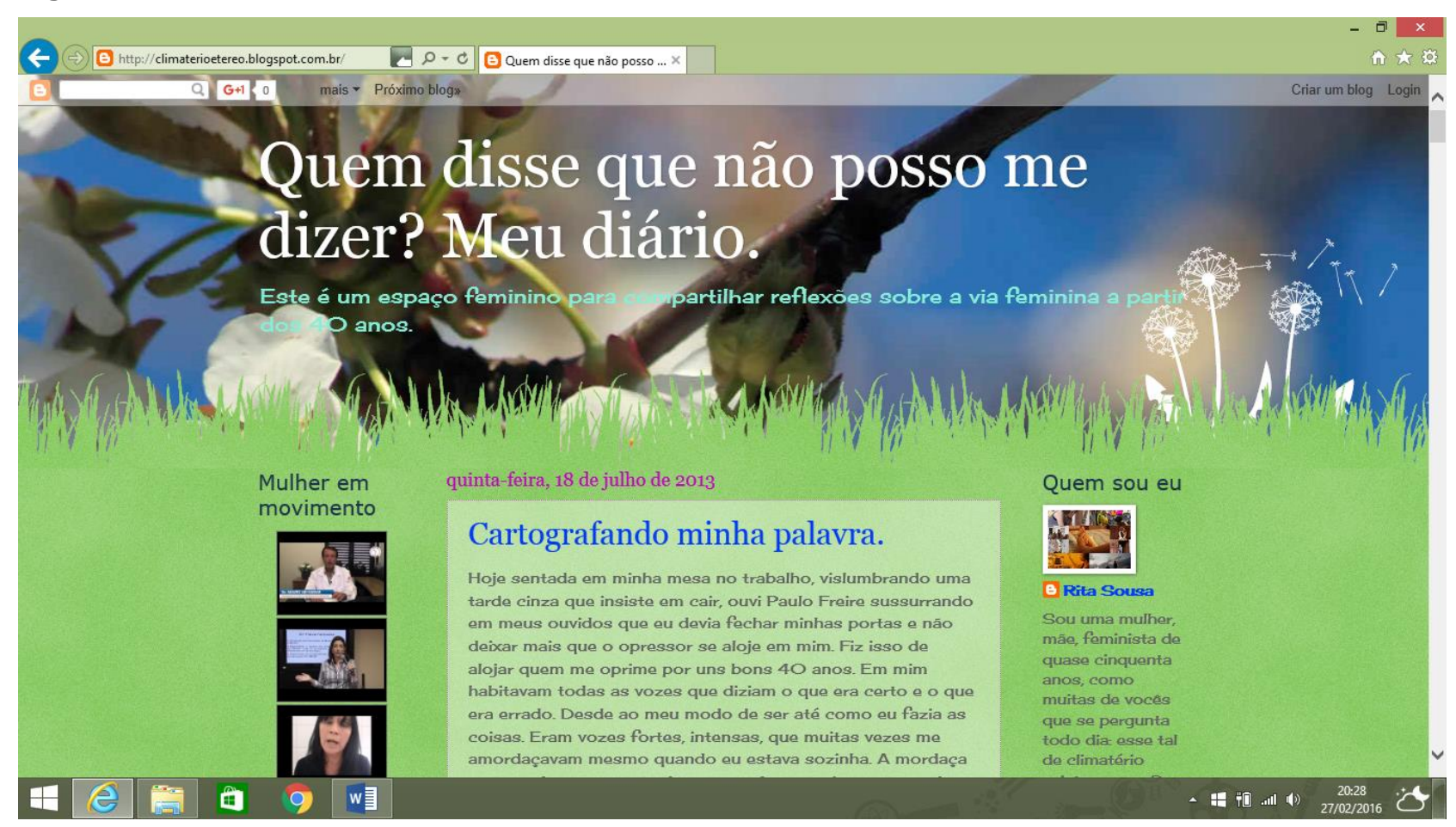

Hoje sentada em minha mesa no trabalho, vislumbrando uma tarde cinza que insiste em cair, ouvi Paulo Freire sussurrando em meus ouvidos que eu devia fechar minhas portas e não deixar mais que o opressor se aloje em mim. Fiz isso de alojar quem me oprime por uns bons 40 anos. Em mim habitavam todas as vozes que diziam o que era certo e o que era errado. Desde ao meu modo de ser até como eu fazia as coisas. Eram vozes fortes, intensas, que muitas vezes me amordaçavam mesmo quando eu estava sozinha. A mordaça era grande, a sensação de estrangulamento intensa e nada me fortalecia o bastante para resistir ou lutar contra cada uma delas. Precisei morrer por dentro, adoecer como um todo com a dor dessa pressão para poder destrancar as portas de mim e expulsá-las todas, ou quase todas. Talvez ainda uma resida aqui, me fazendo chorar e alimentar o medo 
que algumas vezes me faz retroceder ou calar. Como li em um fragmento de um texto: "Paulo Freire já não está entre nós, ou melhor, está em todos nós da rede que teceu... o pensamento, a práxis, enfim o legado de Paulo Freire, não pertence a uma pessoa ou a uma instituição. Pertence a quem precisa dele, e ele tinha consciência de que o que havia escrito pertencia àqueles por quem lutava: os oprimidos." A cada postagem que faço estou exercitando dizer a minha palavra, me dizer um pouco. (SOUSA, 2013) ${ }^{3}$

Depois de me tornar pertencente ao ciberespaço e à blogosfera, voltei então meu olhar sobre um campo novo a ser explorado, o estudo do uso das novas tecnologias e seu impacto sobre a subjetividade humana, em especial as possibilidades de uso dessas ferramentas como facilitadoras da expressão do imaginário e de construção da subjetividade.

Com a navegação diária pelo Facebook, Twitter, portais feministas, blogs autorais e no uso de ferramentas interativas como chats, listas e fóruns de discussão comecei a refletir sobre as possibilidades criativas que o mundo virtual potencializa e desenvolve e como não poderia deixar de ser, pensar em como a construção da subjetividade, a hipertextualidade e a educação podiam andar de mãos dadas, abrindo possibilidades para o ser humano no seu processo sempre em inacabamento na busca de ser sujeito.

\section{Figura 2 - Blog Professora Rita discute}

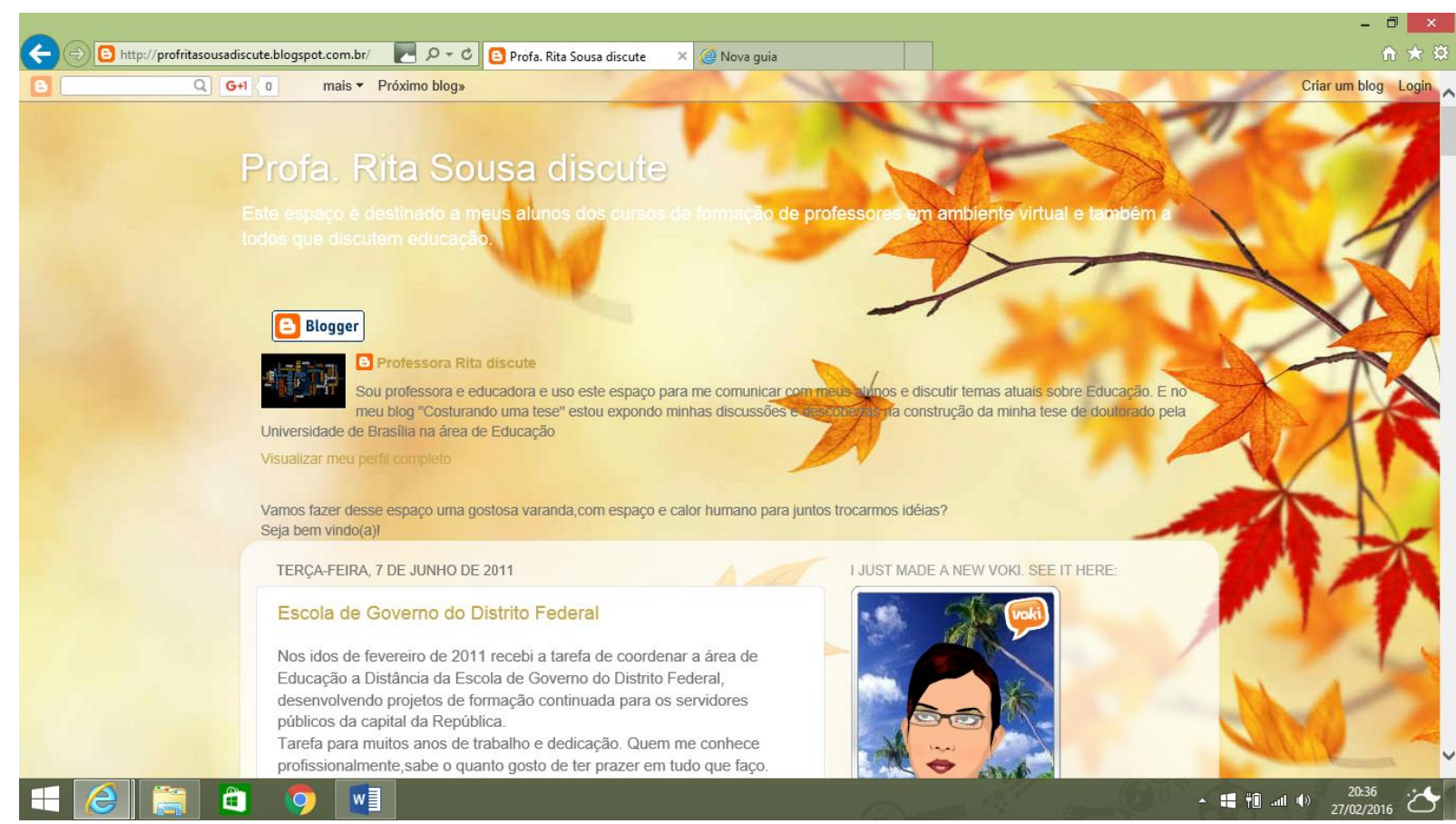

3 SOUSA, Rita. Cartografando minha palavra. 18 de julho de 2013. Disponível em: http://climaterioetereo.blogspot.com.br/2013/07/hoje-sentada-em-minha-mesa-no-trabalho.html. 
Nos idos de fevereiro de 2011 recebi a tarefa de coordenar a área de Educação a Distância da Escola de Governo do Distrito Federal, desenvolvendo projetos de formação continuada para os servidores públicos da capital da República.

Tarefa para muitos anos de trabalho e dedicação. Quem me conhece profissionalmente, sabe o quanto gosto de ter prazer em tudo que faço.

Daí nasceu o curso-piloto de formação de formadores para incentivar a docência entre os profissionais da escola. Para concretizar este deleite, abrimos um curso semipresencial para este fim.

Como atividade avaliativa do curso foi proposto o desenvolvimento de um memorial eletrônico desenvolvido no ambiente de um BLOG.

Este processo está em andamento e estamos acompanhando a construção dos memoriais dos cursistas. Eis os links para quem quiser degustar:

http://eadegov.blogspot.com

http://hermanaraab.blogspot.com

http://fatimaelice.blogspot.com

http://montew.blogspot.com

http://memorialjoanaeluciana.blogspot.com

http://magelke.blogspot.com

http://magalbuq.blogspot.com

http://gasparottosorice.blogspot.com

http://luciano-ivo.blogspot.com

http://keleejulio.blogspot.com

http://formadoresvpl.blogspot.com/

http://rodrigofenixx.blogspot.com/

http://iedaelaine.blogspot.com/

http://julianazenon.blogspot.com/ (SOUSA, 2013) ${ }^{4}$

Como resultado desses movimentos de escrita, de aprendizagem colaborativa, busquei nos estudos do Doutorado, um espaço para refletir sobre a hipertextualidade, suas características, suas peculiaridades, suas potencialidades, seu caráter educativo e identitário. E também para esse processo de construção, abri um blog, um caderno de notas e reflexões que ainda está se fazendo:

${ }^{4}$ SOUSA, Rita. Escola de Governo do Distrito Federal. 07 de junho de 2013. Disponível em: http://profritasousadiscute.blogspot.com.br/. 


\section{Figura 3 - Blog Rita tese}

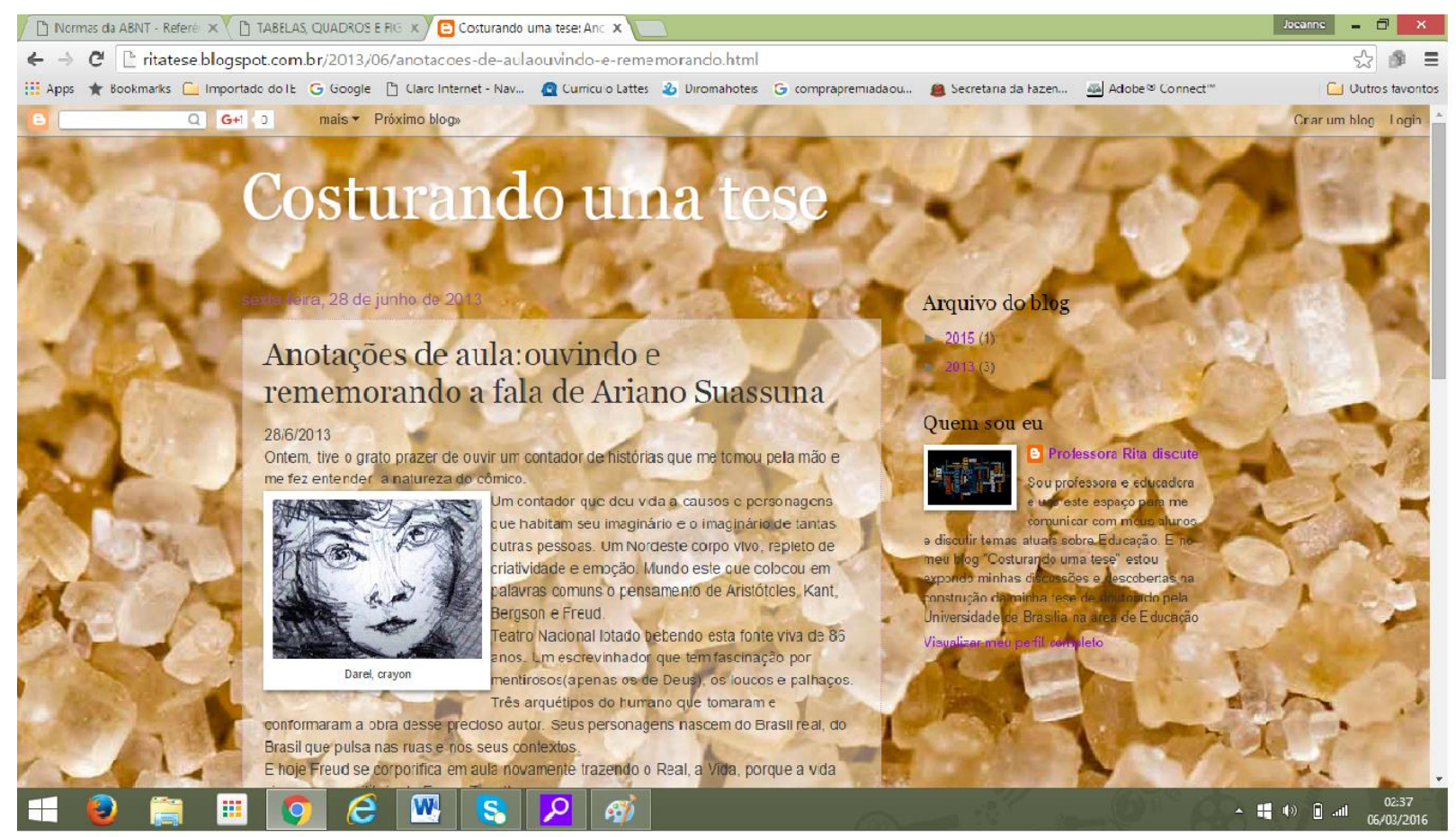

Ontem, tive o grato prazer de ouvir um contador de histórias que me tomou pela mão e me fez entender a natureza do cômico.

Um contador que deu vida a causos e personagens que habitam seu imaginário e o imaginário de tantas outras pessoas. Um Nordeste corpo vivo, repleto de criatividade e emoção. Mundo este que colocou em palavras comuns o pensamento de Aristóteles, Kant, Bergson e Freud.

Teatro Nacional lotado bebendo esta fonte viva de 86 anos. Um escrevinhador que tem fascinação por mentirosos (apenas os de Deus), os loucos e palhaços. Três arquétipos do humano que tomaram e conformaram a obra desse precioso autor. Seus personagens nascem do Brasil real, do Brasil que pulsa nas ruas e nos seus contextos.

E hoje Freud se corporifica em aula novamente trazendo o Real, a Vida, porque a vida vive-se no equilíbrio de Eros e Tanathos. Jung foi chamado para a gira da palavra conceituada e ouvimos e refletimos sobre a fábula do Cuidado. Falamos de marcas, das culpas em relação ao Sagrado e do feminino. E veio para o centro os arquétipos do imaginário coletivo. (SOUSA, 2013)

A construção da subjetividade feminina no ciberespaço, no território demarcado virtualmente como Blogosfera ${ }^{6}$, e sua dimensão educativa é, portanto, o

\footnotetext{
${ }^{5}$ SOUSA, Rita. Anotações de aula: ouvindo e rememorando a fala de Ariano Suassuna. 28 de junho de 2013. Disponível em: http://ritatese.blogspot.com.br/2013/06/anotacoes-de-aulaouvindo-erememorando.html.

${ }^{6}$ As definições de Blogosfera e Blog foram retiradas do artigo: Os novos campos da profissão da informação na contemporaneidade (16 a 22 de janeiro de 2011) de Anagéssica Fernandes Nonato de Oliveira e Edilânia Paulo dos Santos. Disponível em: http://rabci.org/rabci/sites/default/files/BLOGOSFERA\%20blog\%20como\%20fonte\%20de\%20informa
} 
tema da nossa tese. A produção de hipertextos e hipermídias autorais, ancorados em blogs, assim como a relação autor-leitor precisa ser analisada, de modo aprofundado, para entendermos como se dá esta construção de sentidos e como acontece a produção de novos processos de subjetivação em ambos os polos dessa troca dialógica. Um eu que é autor que se narra e um outro que lê e se posiciona diante desse narrar de si.

O advento da tecnologia digital e o seu intenso desenvolvimento alavancado pela criação da Internet favoreceram o surgimento de um ambiente propício à aparição de novas práticas discursivas na sociedade.

Para a clareza do nosso trabalho é preciso esclarecer que o termo "blog", como é mais conhecido pelos internautas, é uma abreviação da palavra weblog, que significa "diário de bordo", no entanto, este passou a mudar a sua finalidade, deixando de ser apenas um diário pessoal para tornar-se um meio de difusão do conhecimento; agora não mais vistos como diários pessoais, mas sim, uma rica fonte de informação. Os blogs proporcionam a quem os utiliza uma rápida fonte de pesquisa, facilitando assim, a busca por informação, sendo esta atualizada diariamente, semanalmente ou mensalmente, etc. Uma grande praticidade com relação às informações que poderão influenciar o público e propor reflexões a quem é alcançado.

Seu uso passou a crescer progressivamente, e hoje é uma ferramenta com múltiplas finalidades, sendo estas muito utilizadas em empresas, em bibliotecas, e no meio universitário. Constantemente usado como forma de propagação de informações entre os usuários da comunidade acadêmica (próprios graduandos como também professores), tornou-se principalmente um novo sistema de compartilhamento de informações. Ressalte-se que uma de suas principais funcionalidades é a facilidade com que esses blogs são criados, fazendo uso apenas de um e-mail, e a partir daí pode-se criar uma conta, fornecendo uma senha e depois é só postar as informações. Surge também como um meio de pesquisa entre os mesmos, destaca-se a capacidade que o blog possui de armazenamento de comentários feitos entre os usuários, tendo em vista o objetivo de contribuição para uma melhor interação entre autor/ leitor.

\%C3\%A7\%C3\%A30.pdf. XIV Encontro Regional de Estudantes de Biblioteconomia, Documentação, Ciência da Informação e Gestão da informação. 
A Blogosfera, por sua vez, é o termo empregado para definir o universo dos blogs, criado em 1999 por Brad L. Graham, em Dezembro de 2001 foi renomeado por Wiliam Quick (VARELLA, 2007). Há muitos "blogueiros" interligados e conectados nessa blogosfera e disponibilizando na rede informações ou notícias. Na maioria são "diários online", um espaço colaborativo, um ambiente para discutir sobre política, destacar noticia recente, colocar links ou também pode servir apenas para dizer o que se está sentido naquele momento ou o que acabou de fazer. Os blogs podem ter várias serventias, entretanto, em relação aos milhares que existem, um número menor pode ser considerado como instrumento de disseminação de informação e de conhecimentos sistematizados.

A blogosfera, portanto, é uma grande rede cercada de páginas organizadas com informações, constituindo o universo dos blogs presente na internet, que podem variar em diversificados tipos de assuntos.

Lévy (2010) corrobora com esta visão ao afirmar que a nova configuração social, cultural, econômica, política e as conexões generalizadas, provenientes dos avanços tecnológicos, colocou em xeque o esquema clássico da informação (emissor-mensagem-receptor) e, abriu espaço para a interatividade. Os sujeitos, nesse novo contexto digital, estão em contato direto com novas concepções de espaço/tempo, podendo com isso, colaborar, produzir e consumir conhecimentos.

Esta necessidade de comunicação, que é inerente à condição humana, faz com que o homem procure ilimitadamente formas de interação com o outro; buscando nesse outro o interlocutor para o entendimento da sua subjetividade. A atividade de linguagem, sendo uma capacidade cognitiva dos indivíduos, acompanha o desenvolvimento da sociedade em seus aspectos sociais, políticos e culturais, fornecendo um extrato da forma de comportamento de seus usuários. Concordamos com Bakhtin (1993), por sua vez, quando ele afirma que "[...] a palavra é capaz de registrar as fases mais íntimas, mais efêmeras das mudanças sociais" (BAKHTIN, 1993, p.65). Essa maneira de pensar gerou em nós a busca pela compreensão da inter-relação que se estabelece em torno das redes de interação social surgidas no contexto do ciberespaço.

Em função dessas mudanças, a construção da subjetividade feminina também vai passar por um processo de transformação diante das conquistas resultantes das lutas feministas no século XX e também a saída da mulher do 
privado para o espaço do mercado de trabalho e novas posturas diante da manifestação da sexualidade feminina. Esta construção fundada na linguagem, na subjetividade e no discurso, tem como eixo três fronteiras, que se apresentam como possibilidades de expressão do Ser: configurações de sentidos subjetivos, uma nova textualidade manifesta na hipertextualidade virtual e a definição de uma identidade político-social.

Todas as teorias orientadas ao desenvolvimento da subjetividade em um novo paradigma reconhecem a importância de formações não conscientes, presentes, tanto nos processos sociais como nas pessoas, assim como o lugar das emoções e do corpo nas expressões humanas. "A única finalidade aceitável das atividades humanas é a produção de uma subjetividade que enriqueça de modo contínuo sua relação com o mundo" (GUATTARI, 1992, p.33).

As teorias que estudam a subjetividade humana compreendem a sociedade organizada em complexos sistemas de natureza subjetiva que são parte da produção das pessoas, destacando outros complexos sistemas que a compõem que não são de natureza subjetiva, mas que tomam diferentes expressões subjetivas nas relações sociais e em seus processos de institucionalização.

Em direção semelhante, caminha a filosofia da linguagem de Bakthin (2009; 2010) com o entendimento de que a linguagem é movimento, que se baseia na enunciação. O diário eletrônico virtual é um texto híbrido, porque ali o autor trabalha com diferentes mídias de natureza verbal, visual e sonora. Buscando, nos diversos formatos midiáticos, reproduzir uma situação de movimento, de conversa e de dialogia. O diário não é mais o texto escrito com seus enunciados, é um texto em movimento que se abre para a hipertextualidade e sua teia de intertextualidade.

Com esse mesmo entendimento, Santaella (2007) acredita que todas as tecnologias interferem na subjetividade humana. Essa pluralidade se manifesta em três matizes que se complementam: texto, som e imagem.

Este é um quadro desafiador, um universo de possibilidades a ser estudado, com reflexos para o campo educativo. Nos propomos a contribuir com esta discussão buscando inicialmente entender: como ocorre a produção da subjetividade feminina em hipertextos virtuais, reunidos sob a forma de diário eletrônico e como se constrói o processo interativo/educativo na relação autor/leitor. 
Com estas questões norteadoras iniciais tivemos como objetivo geral, compreender a produção da subjetividade feminina e seu caráter interativo/educativo, em hipertextos e hipermídias virtuais, ancoradas em diário eletrônico, e em que medida esta produção colabora para o pronunciamento da mulher.

Procuramos a partir desse norte, centrar nosso estudo nos seguintes aspectos:

- Refletir sobre as diversas linguagens midiáticas das postagens hipertextuais dos diários e os recursos discursivos empregados para favorecer o contar de si (autor) para o outro (leitor).

- Analisar, nas narrativas confessionais postadas, os pronunciamentos da autoralleitores e sua finalidade no processo de subjetivação de ambos os polos.

- Analisar os comentários das leitoras, tanto das postagens confessionais quanto de cunho político do diário, para entender a dimensão educativa/intersubjetiva construída nesse intercâmbio.

- Analisar a semiótica das camadas verbais, visuais e sonoras que constituem os hipertextos e suas possibilidades de expressão simbólica do pronunciamento da subjetividade feminina.

Para sustentar esse exercício de interpretação sujeito/ corpus, dialogaremos com teorias e seus teóricos, em uma perspectiva de roda de conversa ou círculo de cultura, porque entendemos a construção do conhecimento enquanto diálogo entre círculos humanos e rizomáticos.

Organizamos esta tese de modo que na primeira seção do texto apresentamos nossa narração de si para deixar marcado o lugar do qual falo como cartógrafa. Na seção teórico-metodológica apresento os círculos teóricos que sustentam a leitura do fenômeno para o qual dirigi meu olhar e em que medida, esses círculos se imbricam e se comunicam, construindo também o círculo metodológico da cartografia que se desenhou diante do que foi visto e ouvido da 
realidade lida. $\mathrm{Na}$ seção interpretativa cartografamos o fenômeno e nos cartografamos com ele, abrindo novos territórios que não nos levaram a conclusões, mas a expansões do movimento de leitura do mundo e das possibilidades educativas dos processos de subjetivação humana. 
II SEÇÃO TEÓRICO-METODOLÓGICA 


\section{CAPÍTULO 2.1 EDUCANDO PARA ALÉM DOS MUROS DA ESCOLA - OS MOVIMENTOS DA SOCIEDADE E SEUS MOVIMENTOS}

A educação pode ser compreendida muito além das dimensões curriculares e do processo de ensino aprendizagem. Essa categoria mescla-se com o conceito de cultura como herança e socialização permanente de saberes, ampliando o sentido epistemológico do termo em si. Paulo Freire na sua obra Pedagogia da Autonomia (1996), por exemplo, afirma que a Educação é um processo humanizante, social, político, ético, histórico, cultural. E este processo pode acontecer a qualquer tempo e em qualquer lugar, mesmo que o espaço institucional destinado para isso, não seja a escola.

Nas últimas décadas do século $X X$ e início do século $X X I$, uma nova conjuntura dá-se no cenário educacional, trazendo para a Educação novos desafios a serem enfrentados. O grande desafio é posto para a Educação na atualidade, diante de um panorama tão diversificado e desigual e de sociedades e movimentos sociais ativos exigindo constantemente novas ações no que tange a esfera pública e privada. Mudanças profundas afetaram as configurações sócio-históricas da educação escolar.

Diante deste cenário, o conceito de Educação amplia-se. E nas palavras de Gohn (2011) não se limitando apenas aos espaços escolares formais, atrelados somente ao processo de ensino-aprendizagem de seus educandos. A Educação é chamada também a transpor os muros da escola, para os espaços da casa, do trabalho, do lazer, do associativismo e outras atividades afins. Configura-se assim um novo campo da Educação que aborda processos educativos fora das escolas ou não, em processos organizativos da sociedade civil, abrangendo organizações sociais e não governamentais, movimentos sociais estratégicos, ou processos educacionais articulados com a escola e comunidade.

\subsubsection{Movimentos Sociais no Brasil}

Em estudo encomendado pelo Grupo de Trabalho Movimentos Sociais e Educação, apresentado na 33ª Reunião Anual da Associação Nacional de Pesquisa 
em Educação - ANPEd, realizada em Caxambu (MG), de 17 a 20 de outubro de 2010, Gohn (2010), reafirma que há um caráter educativo nas práticas que se desenrolam no ato de participar, tanto para os membros da sociedade civil, como para a sociedade mais geral, e também para os órgãos públicos envolvidos quando há negociações, diálogos ou confrontos. Uma das premissas básicas a respeito dos movimentos sociais é: são fontes de inovação e matrizes geradoras de saberes. Entretanto, não se trata de um processo isolado, mas de caráter políticosocial.

A Educação não formal, segundo Gohn (2010): "[...] foi um campo de menor importância no Brasil, até os anos de 1980, tanto nas políticas públicas, quanto entre os educadores". E a esse respeito a autora ainda coloca que o caminho institucional aos processos educativos em espaços não formais foi aberto em 1996 pelo Art. 1ํ da Lei de Diretrizes e Bases da Educação Nacional - LDBEN (BRASIL, 1996), quando define educação como aquela que abrange "[...] processos formativos que se desenvolvem na vida familiar, na convivência humana, no trabalho, nas instituições de ensino e pesquisa, nos movimentos sociais e organizações da sociedade civil e nas manifestações culturais" (BRASIL, 1996; GOHN, 2011, p. 11).

Por outro lado, afirma a autora, a história da Educação no Brasil vem se constituindo como área de conhecimento e área de intervenção social, fruto da interferência significativa dos Movimentos Sociais em diferentes conjunturas sociais políticas e econômicas. O debate sobre a educação das classes populares e sua inserção nas políticas públicas está profundamente vinculado às transformações do trabalho e consequentemente à estrutura política de estado. Em estudo de Fleuri (2002) sobre os caminhos da Educação Popular e a importância dos Movimentos Sociais no Brasil, a autora destaca que:

\footnotetext{
A primeira vertente de educação popular é a que se identifica com a ampliação da educação escolar para todos os cidadãos. A expressão educação popular é usada pela primeira vez por intelectuais, militantes e educadores latino-americanos, entre fins do século passado e começo deste. Uma outra vertente significativa de educação dirigida às camadas populares é a educação de adultos (FLEURI, 2002, p. 52-53).
}

Nesse contexto histórico Gohn (2010) analisa que a educação popular ou as metodologias qualitativas nasceram às margens da sociedade, no extra muro da instituição escolar, e dos espaços de legitimação oficial da educação. Já na década 
de 60 do século $X X$, experiências de organização popular e educação comunitária faziam parte de debates, fóruns e tentativas de articulação com a educação oficial formal.

A frente deste processo, a autora aponta o educador Paulo Freire, como sendo aquele que engenhosamente abriu caminhos para a reflexão sobre o papel do conhecimento, e a responsabilidade social e política dos educadores e, sobretudo, do sentido emancipatório da educação pública. Protagonizou a ideia de sujeito que aprende e que ensina, deslocando o debate sobre o "poder e conhecimento" para "poder, conhecimento e autonomia social". Somente no final da década de oitenta do século XX que tais debates passam a fazer parte das estruturas oficiais do Estado. As políticas de educação como um direito à cidadania (UNESCO; LOAS; ECA) objetivamente estão sendo estruturadas a partir da pressão dos movimentos sociais nestas últimas décadas.

No Brasil, prossegue a autora no seu estudo, essa relação foi sendo vagarosamente construída a partir do fim dos anos 1970, quando foram criadas novas associações ou ativadas entidades científicas já existentes, a exemplo da Associação Nacional de Pós-Graduação e Pesquisa em Ciências Sociais (ANPOCS), a Associação Nacional de Pós-Graduação e Pesquisa em Educação (ANPEd), a Sociedade Brasileira para o Progresso da Ciência (SBPC), a Sociedade Brasileira de Sociologia (SBS) e as Conferências Brasileiras de Educação (CBEs), realizadas bienalmente, que passaram a debater os problemas socioeconômicos e políticos e a destacar os grupos e movimentos sociais envolvidos.

A relação movimento social e educação, segundo Gohn (2010), foi construída a partir da atuação de novos atores que entravam em cena, sujeitos de novas ações coletivas que extrapolavam o âmbito da fábrica ou os locais de trabalho, atuando como moradores das periferias da cidade, demandando ao poder público o atendimento de suas necessidades para sobreviver no mundo urbano. Os movimentos tiveram papel educativo para os sujeitos que o compunham. Já existe, segundo a autora, um acervo considerável de pesquisa sobre aquela época, várias teses, dissertações, livros e outros trabalhos acadêmicos foram produzidos.

A reflexão sobre a produção teórico-metodológica dos movimentos sociais nas últimas décadas, segundo o estudo de Gohn (2008), conta com algumas publicações no Brasil. O livro de S. Tarrow (1994), um dos marcos no debate teórico 
dos movimentos sociais, foi publicado no Brasil somente em 2009. Alain Touraine, entre os autores estrangeiros que analisam os movimentos sociais, o mais conhecido no Brasil, não teve seus primeiros livros traduzidos para o português. M. Castells, que influenciou vários estudos dos movimentos no Brasil nos anos 19701980, também não teve livros publicados na década de 1970 traduzidos no Brasil, sobretudo aqueles nos quais se discutia a análise dos movimentos sociais com novo olhar sobre a questão urbana (GOHN, 2008).

Em síntese, fecha a análise do estudo da autora, apesar do denso quadro de mobilizações e movimentos sociais no país, a partir do fim dos anos 1970, o debate e a produção teórica caminharam lentamente até os primeiros anos deste novo século, embora conte com um grande número de publicações que são registros descritivos, importantes como memórias (GOHN, 2008). No campo da educação, a defasagem é ainda maior. Na primeira década do novo milênio, o tema dos movimentos sociais tem lentamente retornado à agenda dos pesquisadores, sobretudo novos pesquisadores, pautando o debate em eventos e publicações recentes em números temáticos de revistas brasileiras.

$\mathrm{Na}$ atualidade, os principais movimentos sociais avançaram, atuando por meio de redes sociais, locais, regionais nacionais e internacionais ou transnacionais, e utilizam-se muito dos novos meios de comunicação e informação, como a internet. Exercitando com isso uma prática comunicativa que incentiva a criação e o desenvolvimento de novos saberes.

Analisando os dados atuais, Gohn (2010) afirma que os movimentos realizam diagnósticos sobre a realidade social, constroem propostas. Atuando em redes, eles constroem ações coletivas que agem como resistência à exclusão e lutam pela inclusão social. Constituem e desenvolvem o chamado empowerment de atores da sociedade civil organizada à medida que criam sujeitos sociais para essa atuação em rede. Tanto os movimentos sociais dos anos 1980 como os atuais têm construído representações simbólicas afirmativas por meio de discursos e práticas. Criam identidades para grupos antes dispersos e desorganizados. Ao realizar essas ações, a autora entende que projetam em seus participantes sentimentos de pertencimento social. Aqueles que eram excluídos passam a se sentir incluídos em algum tipo de ação de um grupo ativo. 
Segundo a autora, não são só reativos, movidos apenas pelas necessidades (fome ou qualquer forma de opressão); podem surgir e desenvolver-se também a partir de uma reflexão sobre sua própria experiência (GOHN, 2010). Na atualidade, apresentam um ideário civilizatório que coloca como horizonte a construção de uma sociedade democrática. Hoje em dia, suas ações são pela sustentabilidade, e não apenas autodesenvolvimento. Lutam contra a exclusão, por novas culturas políticas de inclusão. Lutam pelo reconhecimento da diversidade cultural.

\subsubsection{Movimento de mulheres no Brasil}

Dentre esses movimentos que refletem sobre sua experiência está o movimento de mulheres que tem se consolidado como um canal de discussão das desigualdades sociais. Segundo Lisboa (2008), nas últimas décadas, constata-se que a exclusão social e a pobreza absoluta têm aumentado no Brasil e na América Latina e o predomínio de mulheres entre os pobres é consequência do desigual acesso feminino às oportunidades econômicas e sociais $O$ ano de 2005 marca 0 décimo aniversário da Conferência Mundial de Pequim sobre as mulheres e traz foco e energia renovados aos esforços para o empoderamento das mulheres. Entre os Objetivos de Desenvolvimento do Milênio (BRASILIA, 2004), consta o objetivo de número 3 (três) que é "Promover a igualdade entre os sexos e a autonomia das mulheres".

Da mesma forma, aponta a autora, o Fórum Econômico Mundial (FEM, 2005), comprometido com a melhoria das condições do mundo, elaborou o documento "Empoderamento das Mulheres - Avaliação das Disparidades Globais de Gênero", definindo cinco dimensões importantes para o empoderamento e oportunidade das mulheres: participação econômica; oportunidade econômica; empoderamento político; conquistas educacionais; saúde e bem-estar (LISBOA, 2008).

Dentre estes campos é que se faz necessário investir no empoderamento das mulheres, destacando-se as conquistas educacionais. Sem educação de qualidade as mulheres não conseguem acesso a empregos bem remunerados do 
setor formal, nem avanços na carreira, participação e representação no governo, reconhecimento de si mesmas como sujeitos de direitos e influência política.

O movimento de mulheres, conforme afirma Lisboa(2008) tem situado o empoderamento no campo das relações de gênero e na luta contra a posição socialmente subordinada das mulheres em contextos específicos. O termo empoderamento chama a atenção para a palavra "poder" e o conceito de poder enquanto relação social. $O$ poder (na ciência política, geralmente vinculado ao Estado) pode ser fonte de opressão, autoritarismo, abuso e dominação. Na proposta do feminismo, porém, pode ser uma fonte de emancipação, uma forma de resistência.

A dimensão de poder na perspectiva feminista, assim como define a autora, é um poder que afirma, reconhece e valoriza as mulheres; é precondição para obter a igualdade entre homens e mulheres; representa um desafio às relações patriarcais, em especial dentro da família, ao poder dominante do homem e a manutenção dos seus privilégios de gênero. Implica a alteração radical dos processos e das estruturas que reproduzem a posição subalterna da mulher como gênero; significa uma mudança na dominação tradicional dos homens sobre as mulheres, garantindo-lhes a autonomia no que se refere ao controle dos seus corpos, da sua sexualidade, do seu direito de ir e vir, bem como um rechaço ao abuso físico e as violações (LISBOA, 2008).

Friedmann (1996, p. 8) citado pela autora, afirma que empoderamento "[...] é todo acréscimo de poder que, induzido ou conquistado, permite aos indivíduos ou unidades familiares aumentarem a eficácia do seu exercício de cidadania”. Ele aponta três tipos de empoderamento, importantes para as unidades domésticas: 0 social, o político e o psicológico.

Este último, como afirma Lisboa (2008), inicia-se com o despertar da consciência em relação à sua autonomia e desenvolvimento pessoal; envolve autoestima e autoconfiança; ter controle sobre a sua própria sexualidade, sobre a reprodução e sobre a sua segurança pessoal; decorre da consciência individual de força. Tanto a autonomia quanto a autoconfiança e controle sobre sua sexualidade são aspectos relevantes quando buscamos entender a organização das mulheres nos espaços comunitários virtuais. 
A luta pela garantia dos direitos fez do movimento de mulheres um corpus em movimento e capaz de expansões e retrações. A história do feminismo tem demonstrando que a discussão sobre gênero passou por diversas fases até chegar na perspectiva atual. O feminismo brasileiro também passou por esse processo.

Rago (2002) em estudo sobre a evolução do feminismo, afirma que décadas depois da incorporação dos estudos feministas e das discussões sobre a categoria do gênero nos debates acadêmicos e nas disputas políticas, é possível dizer que o momento atual das lutas e reivindicações feministas é um "pósfeminismo", entendendo o conceito não como um marco temporal, implicando um momento pré e um pós, mas a partir da instauração de novas configurações nas problematizações e nas relações que se travam no interior desse movimento, quando um determinado patamar de reconhecimento social das questões femininas foi atingido.

$\mathrm{Na}$ atualidade, afirma a autora, não apenas as mais jovens entram de outro modo no mercado de trabalho e no mundo público, isto é, com muito mais autonomia do que as mulheres com essa idade experimentaram em décadas anteriores, como também se encontram em condições de estabelecer relações de gênero bastante relaxadas e bem menos hierarquizadas, se compararmos novamente com aquelas vivenciadas pelas que tinham vinte anos na década de 1960 (RAGO, 2002).

A autora também entende que a juventude pós-feminista, em boa parte educada por pais antiautoritários, críticos das formas educacionais herdadas, sobretudo nas camadas médias e mais intelectualizadas da população, mantêm relações mais libertárias com o corpo, com o sexo, com o outro, com a natureza e com a própria vida. De certo modo, continua ela, o discurso feminista, tanto quanto o ecológico, o étnico, para não falar do anarquista e socialista em geral foi incorporado em muitas dimensões, produzindo importantes efeitos na sensibilidade e no imaginário social, claramente perceptíveis na vida cotidiana.

Nesse artigo, Rago (2002) vai mais profundamente na análise do movimento de mulheres quando afirma que há um reconhecimento social, na atualidade, de que as lutas feministas afetaram positivamente a maneira pela qual se deu a incorporação das mulheres no mundo do trabalho, num momento de ampla modernização socioeconômica no Brasil, desde os anos setenta, e que contribuíram 
para que houvesse grandes mudanças, apesar do regime ditatorial estabelecido, nos códigos morais e jurídicos, nos valores, nos comportamentos, nas relações estabelecidas consigo e com os outros, nos sistemas de representações e no modo de pensar, ainda não plenamente avaliadas. Especialmente a partir da constituição de um novo olhar sobre si e sobre o outro - e, nesse sentido, a autora aponta o surgimento de um processo de feminização cultural em construção:

[...] o mundo tem-se tornado mais feminino e feminista, libertário e solidário ou, em outras palavras, filógino, - isto é, contrário a misógino -, amigo das mulheres e do feminino, o que resulta decisivamente do aporte social e cultural das mulheres no mundo público (RAGO, 2002, p.3).

Outro aspecto levantado por Rago (2002), em seu artigo, é sobre a mudança de paradigma pelo que passou a luta feminista quando se trata da discussão do sujeito e da subjetividade. Para a autora o feminismo criou um modo específico de existência, muito mais integrado e humanizado, já que desfez oposições binárias como a que hierarquiza razão e emoção, inventou eticamente, e tem operado no sentido de renovar e reatualizar o imaginário político e cultural de nossa época.

O feminismo, afirma a autora, investiu contra o sujeito, não apenas tendo como alvo a figura do homem universal, mas visando a própria identidade da mulher. Desnaturalizando-a, mostrou o quanto a construção de um modelo feminino universalizante foi imposta historicamente pelo discurso médico vitoriano, pelo direito, pela família, pela igreja, enfim, pelo olhar masculino reforçado, principalmente nos centros urbanos, pelos estímulos da indústria de consumo.

Já são inúmeros os estudos, pesquisas, livros, publicações e revistas que
desconstroem as muitas leituras sobre o corpo e a fisiologia da mulher, seus
sentimentos, desejos e funcionamentos físicos e psíquicos, subvertendo
radicalmente a ordem masculina do mundo, especialmente ao desconectar
a associação estabelecida entre origem e finalidade, que justificava a
definição de uma suposta essência feminina a partir de sua missão para a
maternidade (RAGO, 2002, p. 7).

Rago (2009), em outro artigo, afirma que a crítica feminista foi radical ao buscar a libertação das formas de sujeição impostas às mulheres pelo patriarcalismo e pela cultura de consumo da sociedade de massas e, se num primeiro momento, o corpo foi negado ou negligenciado, como estratégia mesma dessa recusa das 
normatizações burguesas, desde os anos oitenta, no Brasil principalmente, percebese uma mutação nessas atitudes e a busca de novos lugares para o feminino. Essa busca, segundo a autora, estimula a emergência de novas formas de feminilidade, de novas concepções de sexualização, beleza e sedução.

Segundo o site da Rede Mulher e Educação ${ }^{7}$, organização não governamental feminista criada em 1980, a década de setenta constituiu um marco para o movimento de mulheres no Brasil, com suas vertentes de movimento feminista, grupos de mulheres pela redemocratização do país e pela melhoria nas condições de vida e de trabalho da população brasileira.

Em 1975, comemorou-se, em todo o planeta, o Ano Internacional da Mulher e realizou-se a I Conferência Mundial da Mulher, promovida pela Organização das Nações Unidas - ONU, instituindo-se a Década da Mulher.

Em fins dos anos setenta, portanto, e durante a década de oitenta, o movimento se amplia e se diversifica, adentrando partidos políticos, sindicatos e associações comunitárias. Com a acumulação das discussões e das lutas, o Estado Brasileiro e os governos federal e estaduais reconhecem a especificidade da condição feminina, acolhendo propostas do movimento na Constituição Federal (1988) e na elaboração de políticas públicas voltadas para o enfrentamento e superação das privações, discriminações e opressões vivenciadas pelas mulheres.

Como exemplo, o site citado, destaca a criação dos Conselhos dos Direitos da Mulher, das Delegacias Especializadas de Atendimento à Mulher, de programas específicos de Saúde integral e de prevenção e atendimento às vítimas de Violência Sexual e Doméstica.

Segundo a Articulação de Mulheres Brasileiras - $A M B^{8}$, movimento feminista que reúne mais de vinte fóruns, redes e articulações estaduais de mulheres e, através destes, articula centenas de organizações, grupos, ONGs e movimentos de mulheres em todo o território nacional, nos anos noventa, amplia-se o movimento social de mulheres e surgem inúmeras organizações nãogovernamentais (ONGs). Além de uma diversidade e pluralidade de projetos, estratégias, temáticas e formas organizacionais, constata-se a

\footnotetext{
${ }^{7}$ Disponível em: http://www.redemulher.org.br.

${ }^{8}$ Disponível em: http://pndh3.com.br/geral/articulacao-de-mulheres-brasileiras.
} 
profissionalização/especialização dessas ONGs. Também nesta década, consolidam-se novas formas de estruturação e de mobilização, embasadas na criação de redes/ articulações setoriais, regionais e nacionais, a exemplo da Articulação de Mulheres Brasileiras - AMB, da Rede Nacional Feminista de Saúde e Direitos Reprodutivos - Rede Saúde e de articulações de trabalhadoras rurais e urbanas, pesquisadoras, religiosas, negras, lésbicas, entre outras.

Paralelamente, são desencadeadas campanhas como "Mulheres Sem Medo do Poder", visando estimular e apoiar a participação política das mulheres nas eleições municipais de 1996; "Pela Vida das Mulheres", visando manter o direito ao aborto nos casos previstos no Código Penal Brasileiro (risco de vida da mãe e gravidez resultante de estupro); "Pela Regulamentação do Atendimento dos Casos de Aborto Previstos em Lei, na Rede Pública de Saúde"; e "Direitos Humanos das Mulheres", por ocasião da comemoração dos 50 anos da assinatura da Declaração Universal dos Direitos Humanos (1948), visando incorporara história das mulheres.

Nessa década, o movimento aprofunda a interlocução com o Legislativo e o Executivo - e, em menor medida, com o Judiciário -, tanto no sentido da regulamentação de dispositivos constitucionais, quanto no sentido da implementação de políticas públicas que levem em conta a situação das mulheres e perspectiva de equidade nas relações de gênero.

Segundo a Rede Mulher de Educação, as mulheres brasileiras, enquanto integrantes e representantes de organizações do movimento de mulheres, estão articuladas e sintonizadas com o movimento de mulheres internacional, particularmente o Latino-americano e do Caribe, O Movimento de Mulheres participou e contribuiu nos grandes fóruns internacionais, a exemplo das Conferências Mundiais da ONU - sobre Direitos Humanos (Viena, 1993), População e Desenvolvimento (Cairo, 1994) e Mulher, Igualdade, Desenvolvimento e Paz (Beijing, 1995) - e da Convenção Interamericana para Prevenir, Punir e Erradicar a Violência Contra a Mulher (Belém do Pará, 1994), da Organização dos Estados Americanos - OEA. 
Segundo o documento base da $4^{a}$ Conferência Nacional de Políticas para as Mulheres $^{9}$, a prática de realização de conferências nacionais foi instituída como estratégia política a partir de 1988. O governo do Partido dos Trabalhadores (PT), a partir de 2003, legitimou a realização de conferências tornando-as amplas, abrangentes e inclusivas, como parte da democracia participativa.

Em 2002, segundo o mesmo documento, organizações do movimento feminista brasileiro realizaram a Conferência Nacional de Mulheres Brasileiras. Em 2004 a Presidência da República, através da Secretaria de Políticas para Mulheres convocam a $1^{\underline{a}}$ Conferência Nacional de Políticas para as Mulheres, fortalecendo as políticas voltadas para as mulheres e descentralizando para as esferas estaduais e municipais a gestão das políticas públicas.

Com esta configuração, o movimento de mulheres possui uma metodologia própria de fazer política.

\subsubsection{O movimento de mulheres como um fazer educativo}

Para Streck (2006), a educação popular tem como uma de suas marcas acompanhar o movimento de classes, grupos e setores da sociedade que entendem que o seu lugar na história não corresponde aos níveis de dignidade a que teriam direito. Isso pode significar a reivindicação de espaço na estrutura existente, mas pode também representar o engajamento na luta por rupturas e pela busca de novas possibilidades de organização da vida comum. O elemento definidor, neste caso, não é tanto o projeto final, mas a disponibilidade para sair do lugar, o mover-se em direção a um horizonte que apenas deixa entrever sinais do que Paulo Freire em Pedagogia do Oprimido (1987) chamou de inéditos viáveis. Quer definamos a educação popular com base nos objetivos, no método, no conteúdo, no contexto ou nos sujeitos, sempre haverá dúvidas sobre o que ela é de fato.

A história da educação popular geralmente é contada a partir da década de 1960, que no Brasil coincide com uma forte mobilização popular na qual se encontrava inserida a educação, em especial a alfabetização de adultos. Para o

9 Disponível em: http://www.spm.gov.br/4a-conferencia-nacional-de-politicas-para-as-mulheres/4acnpm-texto-base-versao-integral.pdf. 
mesmo autor, a referência mais marcante desse movimento pedagógico-políticocultural é o projeto de Paulo Freire em Angicos, no Rio Grande do Norte, em 1963.

Dentre os movimentos implantados no Nordeste, todos no início da década de 1960, podem ser citados o Movimento de Cultura Popular (MCP), criado na Prefeitura de Recife; a campanha "De pé no chão também se aprende a ler", instituída pela Prefeitura de Natal (RN); e o Movimento de Educação de Base (MEB), criado pela Conferência Nacional dos Bispos do Brasil em convênio com o governo federal.

Para Carmen da Silva (2013), educadora e feminista histórica do SOS Corpo Instituto Feminista para a Democracia ${ }^{10}$ as organizações e movimentos feministas, em sua grande maioria, têm como parte substancial da sua ação cotidiana o trabalho educativo. Isso indica que educação é um elemento constitutivo fundamental da auto-organização das mulheres, mas também que as organizações que impulsionam o feminismo veem na práxis educativa uma forma de relação com as mulheres que ainda não estão participando do movimento, com outros movimentos sociais e com a sociedade como um todo.

Esta organização da sociedade civil, autônoma, sem fins lucrativos, fundada em 1981, com sede na cidade do Recife (PE), na região Nordeste do Brasil, é emblemática na formação e organização do movimento feminista brasileiro. Tem como proposta contribuir para a democratização da sociedade brasileira por meio da promoção da igualdade de gênero com justiça socioambiental. Sua ação tem como fundamento a ideia de que os movimentos de mulheres, como movimentos sociais organizados que lutam pela transformação social, são sujeitos políticos que provocam mudanças nas condições de vida das mulheres em geral. A luta contra a pobreza, o racismo e a homofobia são dimensões fundamentais do feminismo da transformação social para o enfrentamento do sistema capitalista e patriarcal, produtor de desigualdades e sofrimento humano.

Para a autora, o movimento feminista é um movimento social de mulheres por sua liberdade e autonomia e pela libertação da humanidade da opressão e exploração (SILVA, 2013). Neste sentido, o feminismo tem um caráter civilizatório, pois questiona os princípios estruturantes deste modo de civilização em curso no

${ }^{10}$ Disponível em: http://www.soscorpo.org.br/quem-somos.html. 
atual estágio da sociedade. É um movimento composto por diferentes tipos de organização - grupos populares locais, organizações profissionais da sociedade civil de caráter auto gestionário (também chamadas ONGs), grupos acadêmicos, grupos de mulheres de movimentos sociais, sindicatos e partidos - e redes nacionais voltadas para ação política que são capazes de congregar a diversidade de grupos existentes e que admitem também inserção individual.

A resistência cotidiana das mulheres às formas de dominação às quais estão submetidas é o manancial de onde o movimento feminista retira sua força.

O feminismo é um apoio à dimensão individual da emancipação, a auto constituição como sujeito de sua própria vida, e, ao mesmo tempo, um instrumento para o enfrentamento coletivo da opressão e exploração das mulheres (SILVA, 2013, p.32).

Silva (2013) avança sua discussão neste texto, afirmando que o sentido do trabalho educativo no movimento feminista é contribuir para a formação das mulheres para ação política feminista transformadora. Esta compreensão inclui a aquisição de conhecimentos já sistematizados e a perspectiva de fortalecimento do sujeito individual, e vai um pouco além: exige a geração de condições de fortalecimento do feminismo como sujeito político coletivo.

Como a autora, vemos que a partir do diálogo entre a educação realizada por grupos de mulheres feministas e a concepção pedagógica de educação popular freireana, desenvolve-se um conjunto de elementos que podem ser sistematizados para uma perspectiva educacional dialógica de fato.

Se tomarmos alguns elementos que os grupos de mulheres no Brasil têm tentado pôr em prática: a dialogicidade e o ato político-educativo de ouvir as mulheres, em uma escuta sensível e solidária, como um dos fundamentos da construção do conhecimento na prática educativa a partir das experiências cotidianas; a visão de mulheres, como sujeitos do conhecimento e da ação política transformadora de suas vidas e do mundo; o necessário impulso, para isso, da autoorganização das mulheres como movimento feminista autônomo, ou seja, constituído por mulheres e em torno da causa das mulheres; a perspectiva crítica permanente frente ao mundo, as teorias que o explicam e até mesmo frente a este próprio movimento social (SILVA, 2013). 
Na compreensão desta autora, estas premissas podem nortear a práxis educacional do movimento feminista. No interior desta práxis, estes elementos contribuem para pensar a formação como processo permanente de reflexão sobre sua própria experiência cotidiana e sobre a ação feminista coletiva.

\begin{abstract}
Ao vermos este sentido na ação educativa do movimento social feminista formar para ação política transformadora de si mesmas e do mundo reafirmamos que, entre outros elementos, esta concepção de transformação social enuncia que as mulheres devem ser ouvidas no ato educativo sobre sua experiência de ser mulher e sobre sua interpretação sobre "as mulheres". Com isso queremos contribuir para a formação da pessoa, em seu processo de crescimento próprio, e para fortalecer o pertencimento ao movimento e a sua ação política (SILVA, 2013, p.13).
\end{abstract}

Esta ação coletiva tem acontecido em vários espaços: nas ruas, nas marchas, nos meios de comunicação tradicionais e na internet. Segundo o blog do movimento feminista que se intitula Marcha Mundial das Mulheres ${ }^{11}$, em 2012, o Ciberativismo tem se mostrado como uma das mais importantes e dinâmicas ferramentas de mobilização do novo século, realizando o conceito do it yourself (faça você mesmo/a). A internet desenvolveu um meio de comunicação de difícil controle, através da qual a militância divulga suas propagandas ideológicas e políticas.

Sem a internet, segundo o site, e a interatividade democrática que a internet permite, seriam muito mais difíceis as reflexões acerca da sociedade, as ações de repúdio e as mobilizações que têm tomado cada vez mais amplitude, como A Marcha das Vadias e a Marcha das Margaridas. Nessas mobilizações, a internet tem papel fundamental.

A internet, segundo a mesma postagem da Marcha, a internet auxilia no combate ao machismo da mídia, explicitada em propagandas de televisão, sites e programas:

Nada passa batido, pois vários blogs e páginas feministas produzem e propagam um "contra conteúdo", ou um contraponto fundamental às ações machistas dos velhos conteúdos midiáticos. Toda essa movimentação só é possível a partir da internet como um espaço livre de ideias, contudo, esse espaço está ameaçado no Brasil. ${ }^{12}$

\footnotetext{
11 Endereço eletrônico: https://marchamulheres.wordpress.com/2012/11/19/feminismo-2-0-acontribuicao-do-ciberativismo-para-o-movimento-de-mulheres-e-a-importancia-do-marco-civil-dainternet/). Acessado em: 13 fev. 2016.

12 Disponível em: https://marchamulheres.wordpress.com/2012/11/19/feminismo-2-0-a-contribuicaodo-ciberativismo-para-o-movimento-de-mulheres-e-a-importancia-do-marco-civil-da-internet/).

Acessado em: 13 fev. 2016.
} 
Dessa forma temos claro que o ciberespaço deu um novo impulso aos movimentos de mulheres, e o sentimento de pertencimento dessa ferramenta tem cada vez se tornado expressivo e definitivo entre as mulheres no presente século. 


\section{CAPÍTULO 2.2 A TRAMA DE FIOS TEÓRICOS E OLHARES PARA TECER MEU TAPETE}

Com o desenho do contexto sócio-político e educativo do movimento de mulheres, mais especificamente no ciberespaço, quando se organizam em portais e se pronunciam na Blogosfera, entendemos que será necessário sustentar nossa pesquisa em quatro eixos integrados, formados por teóricos que se irmanaram em círculos, para que juntos e em dialogia pudessem construir conhecimentos que os aproximasse do humano, na sua magnitude: a Teoria da subjetividade de Guattari (1987; 1988; 1990; 1992), que em muitos momentos dialoga com Deleuze (1988; 1996; 2002), para fundamentar a discussão sobre a construção do processo de subjetivação do autor/leitor do diário eletrônico em estudo; a Teoria da Linguagem discutida pelo Círculo de Bakthin $(2003 ; 2008 ; 2009 ; 2010)$ que possibilitará a compreensão da relação de interação dialógica entre a o autor do diário e seus leitores; e, para entender e interpretar o uso da linguagem escrita, sonora e visual dos hipertextos digitais, trabalharemos teórico e metodologicamente com a cartografia deleuziana e guattariana e suas possibilidades de mapeamento da produção autoral, e deixando-nos também guiar pela bússola de Santaella (2001; 2007; 2007a; 2011) quando analisa a atualidade como era da mobilidade e linguagens líquidas, tomando como norte a aplicação de conceitos semióticos peirceanos.

Nada mais justo, uma vez que Guattari e Deleuze trabalham com formas rizomáticas e em rede para entender o estar no mundo e Pierce vê o ser humano como signo ele mesmo, cartografando infinitamente seus desejos mediante signos, ícones e símbolos que estão para além da linguagem humana.

E por fim, o pensamento freireano, também em vários momentos construído fraternalmente com outros teóricos, para refletirmos sobre a dimensão educativa e colaborativa do processo de subjetivação feminina no ciberespaço. 


\subsubsection{A teoria da subjetividade de Guattari - do sujeito e suas revoluções}

O tempo é a tardança daquilo que está por vir.

Martin Fierro

Poderíamos dizer tradicionalmente que Pierre-Félix Guattari foi um filósofo e militante revolucionário francês. Atuou com Gilles Deleuze, e juntos escreveram Anti-Édipo (1972), Capitalismo e Esquizofrenia (1996) e O que é Filosofia? (1991), entre outras obras. Mas, para o nosso trabalho é importante frisar que ele criou uma obra na qual o problema do desejo singular é inseparável do político, da indústria, da informática, das instituições. Ele coloca o problema da subjetividade no centro das questões políticas e sociais contemporâneas.

Segundo Warat (1992), em um artigo emocionado, Guattari foi um "filoesteta" apegado à criatividade e às práticas de singularidade da subjetividade individual e coletiva (entendendo ainda que seria impossível a singularidade individual fora de contextos coletivos solidários):

Um ecologista da vida cotidiana em permanente questionamento das crenças preestabelecidas, dos desejos manipulados pelas instituições, das arrogâncias dos grandes princípios, enfim, de tudo o que impossibilitasse 0 devir do desejo para a sua própria singularidade (WARAT, 1992, p.80).

Guattari foi um filósofo que tentou problematizar seu presente, e segundo o autor, ele para isso fugiu, dos claustros universitários. Sua militância foi nos meios de comunicação, para fazer a guerra e exercitar sua cólera contra sua época em praça pública, sua micropolítica se dava nas suas incursões cartográficas sobre a realidade que o circundava.

Warat(1992) descreve Deleuze como o grande parceiro de Guattari. Os teóricos escreveram a duas mãos o "Anti-Édipo" (1972), um livro que, reinterpretou o maio de 68 francês, abalou a década de 1970,

[...] denunciando presumidas insuficiências na concepção do inconsciente freudiano que não se encarrega das determinações políticas do desejo e também as limitações da teoria marxista que não levou em conta o desejo como produtor da realidade (WARAT, 1992, p. 80). 
A dupla Guattari-Deleuze e suas produções sempre causam polêmica. São bastante difundidos e aceitos entre os estudiosos da saúde mental. Os teóricos da filosofia, por outro lado, os rejeitam sem concessões, não aceitam suas estratégias de interpretação de autores como Espinoza, Nietzsche, Leibniz e outros, fazendo dessa apropriação um método para sua filosofia cartográfica.

\begin{abstract}
Uma atitude de apropriação do saber do outro feito com o propósito de desvendar os deslizes, os silêncios, as vozes silentes dos roubados. Falar o que o outro não se atreveu a dizer. Uma coisa que os funcionários da filosofia não querem entender (WARAT, 1992, p. 80).
\end{abstract}

Os textos de Guattari, segundo Warat (1992), sugerem um nome para sua postura: filoestética; uma filosofia dirigida diretamente para os não-filósofos, que unifica vida e obra, que atravessa e entrecruza os mais heterogêneos lugares (cinema, poesia, televisão, ecologia, psicanálise, rádio pirata, etc.), atendendo com isto ao anseio de transformar a vida e pensar o próprio presente:

Entrecruzamento de lugares e saberes realizado através de uma fuga das posturas cientificistas em direção a formas expressivas ético-estéticas. Uma ruptura com a filosofia mascarada e com os filósofos de ofício que fazem do ideal asséptico de sua aparência exterior um arremedo de sentido para suas vidas distantes do mundo, como diz Deleuze falando junto a Nietzsche (WARAT, 1992, p. 80-81).

Esta escolha se consolidou por entendermos que Guattari traça linhas convergentes com o pensamento bakthiniano e trabalha sob um paradigma que concebe a história do homem sobre o mundo como uma teia de relações e rizomas que se expandem e se contraem em um movimento constante e infinito de construção e reconstrução do sujeito.

O conceito produção de subjetividade de certa forma ajuda na discussão que trataremos neste estudo, quando queremos entender de que maneiras são engendradas as mais diversas formas de ver, sentir e estar no mundo e se constituir como sujeito, processo profundamente educativo, tendo como contexto o ciberespaço, as redes sociais e o uso do hipertexto e da hipermídia para dialogar com o outro e consigo mesmo.

Entendemos, assim como Guattari, a subjetividade como substancial e como produzida. Neste segundo caso, tomaremos a subjetividade como processo. $\mathrm{Na}$ descrição desse processo, o autor trabalha com os conceitos de máquina e de agenciamentos coletivos de enunciação. 
Para o autor, o agenciamento coletivo não é uma entidade individuada, nem uma entidade social predeterminada. Esses processos são duplamente descentrados. Em Cartografias do Desejo (1993; 2013), Guattari e Rolnik discorrem sobre a implicação que envolve essa produção. Por um lado, e, concomitantemente há máquinas de expressão de natureza extrapessoal, extraindividual e outras máquinas de natureza infra-humana, infra-psíquica e infrapessoal. E melhor entenderemos esse processo e podemos atuar de maneira antiagenciamento se elucidarmos como estas estâncias entram em conexão.

Para explicitar melhor esta teorização, o autor procura deixar claro que o conceito de indivíduo e subjetividade não estão associados. O primeiro é o resultado de uma produção em massa e modelada. O segundo por sua vez, não se submete a uma totalização ou redução. Para materializar melhor este pensamento, o autor toma como exemplo o modo de subjetivação do sonho, onde explode a individuação da subjetivação e toma como exemplo comparativo o ato de dirigir um carro, neste ato, o indivíduo dá espaço para uma articulação servo-mecânica com o carro, porque se torna algo quase automático e sem interferência direta da consciência. Entretanto, esta pode ser ativada rapidamente com o surgimento de sinais de perigo. Isto faz com que o indivíduo enquanto ego sempre pode estar presente. Mas quando adentramos o campo da linguagem e do desejo estamos em outro espaço:

\begin{abstract}
Mas a produção da fala, das imagens, da sensibilidade, a produção do desejo não se cola absolutamente a essa representação do indivíduo. Essa produção é adjacente a uma multiplicidade de agenciamentos sociais, a uma multiplicidade de processos de produção maquínica, as mutações do universo de valores e de universos da história (GUATTARI; ROLNIK, 2013, p.40).
\end{abstract}

Desde a concepção substancial até esta concepção "maquínica", essas transformações seguem o caminho de uma lenta e progressiva mudança de orientação no curso do pensamento filosófico ocidental: do eixo vertical (que poderíamos chamar de eixo fundacional), que estabelece bases sólidas para os sistemas filosóficos, para o eixo horizontal, ou "eixo conectivo", "rizomático", que desmonta o fundamento último das coisas e revela seu caráter fragmentário, descontínuo e acidental. 


\title{
2.2.1.1 A produção da subjetividade
}

A produção da subjetividade se situa no contexto em que a cultura de massa é entendida como elemento chave para compreender a produção da subjetividade no mundo capitalista. Essa cultura, segundo Guattari e Rolnik (1993; 2013), apresenta uma máquina abstrata que produz indivíduos submetidos a sistemas de valores hierárquicos que se apresentam de modo dissimulado e invisível. A subjetividade se produz, portanto, em um plano imanente e de modo serializado e globalizante. "[...] assim como se produz leite em forma de leite condensado, com todas as moléculas que the são próprias, injetam-se nas mães, nas crianças, como parte do processo de produção subjetiva" (GUATTARI; ROLNIK, 2013, p. 33).

Para estes autores, a forma como nos relacionamos com o mundo está sempre permeada pelos dispositivos e agenciamentos que nos atravessam, delimitando nossas "zonas existenciais" ou nossos territórios intensivos.

Entendem que a noção de subjetividade não é algo pessoal ou subjetiva do indivíduo, porque existem diferentes tipos de individuação:

\begin{abstract}
[...] uma coisa é a individuação do corpo. Outra é a multiplicidade dos agenciamentos de subjetivação: a subjetividade é essencialmente fabricada e modelada no registro social. Descartes quis colar a ideia de subjetividade consciente à ideia de indivíduo. Colar a consciência subjetiva à existência do indivíduo, e estamos nos envenenando com uma equação ao longo de toda a história da filosofia moderna. Nem por isso, deixa de ser verdade que os processos de subjetivação são fundamentalmente descentrados em relação à individuação (GUATTARI; ROLNIK, 2013, p. 40).
\end{abstract}

Em todas as ações humanas no cotidiano sempre está presente a dimensão individual, a totalidade egoica, como denomina o autor, mas esta desaparece quando outros fatores interferem, como a competência técnica ou até mesmo a postura alerta diante de situações de perigo. Para os autores, a produção da fala, das imagens, da sensibilidade, a produção do desejo não se restringe apenas ao indivíduo, mas à multiplicidade de agenciamentos sociais, a mutações de valores e históricas.

A micropolítica proposta por Guattari passa pelo questionamento da noção de indivíduo, como a referência dos processos de subjetivação. Sua definição 
de subjetivação é bem mais ampla porque considera os processos de produção social e material (GUATTARI; ROLNIK, 2013).

A subjetividade, assim como a linguagem, é essencialmente social, mas assumida e vivida, na visão do autor, por indivíduos em suas existências particulares:

\begin{abstract}
Não existe uma subjetividade do tipo "recipiente" onde se colocariam coisas essencialmente exteriores, que seriam "interiorizadas". As tais "coisas" são elementos que intervêm na própria sintagmática da subjetivação inconsciente. São exemplos de "coisas" desse tipo: um certo jeito de utilizar a linguagem, de se articular do modo de semiotização coletiva (sobretudo da mídia); uma relação com o universo das tomadas elétricas, nas quais se pode ser eletrocutado, uma relação com o universo de circulação na cidade. Todos esses são elementos constitutivos da subjetividade (GUATTARI; ROLNIK, 2013, p. 43).
\end{abstract}

O indivíduo está envolvido, portanto, por vários elementos da subjetividade. Há aqueles que são inconscientes, outros do domínio do corpo, outros do domínio dos grupos aos quais pertence socialmente. Outros no domínio da produção do poder. E por fim, o autor ainda aponta uma subjetividade mais ampla a qual ele denomina de capitalística.

Nos processos de subjetivação na perspectiva de Guattari (1993, apud ROLNIK, 2007), quando mais o ser humano se deixa roçar pelo mundo, quando se abre para encontros, afetando e se deixando afetar, vai variar de acordo com os agenciamentos que faz suas práticas afetivas, suas aventuras, seus amores e suas perdas.

Guattari (1993), entende a subjetividade como processo e como devires, porque:

Criam-se novas modalidades de subjetivação do mesmo modo que o artista plástico cria novas formas a partir da palheta que dispõe. [...] A subjetividade é o conjunto das condições que torna possível que instâncias individuais e/ou coletivas estejam em posição de emergir como território existencial auto-referencial, em adjacência ou em relação de delimitação com uma alteridade ela mesma subjetiva (GUATTARI; ROLNIK, 2013, p.19).

Esta subjetividade coletiva apontada por Guattari (GUATTARI; ROLNIK, 2013), não é a somatória de subjetividades individuais. Para o autor, o processo de singularização da subjetividade se realiza quando se aglomera, se associa e se empresta diversas dimensões. 
Pode acontecer de processos de singularização portadores de vetores de desejo encontrarem processos de individuação. Nesse caso trata-se sempre de processos de responsabilização social, de culpabilização e de entrada na lei dominante (GUATTARI; ROLNIK, 2013, p. 46).

Para Guattari (GUATTARI; ROLNIK, 2013), o processo de individuação se dá em três níveis: o biológico que envolve a sobrevivência humana, o da divisão sexual que nos distingue em termos de gênero e o nível das relações socioeconômicas, quando somos coagidos a assumir esta ou aquela classe. Para o autor o processo de subjetivação, de singularização não está ligado diretamente ao indivíduo. "A meu ver, não existe unidade evidente da pessoa: o indivíduo, o ego ou a política do ego, a política da individuação da subjetividade, são correlativos de sistemas de identificação os quais são modelizantes" (GUATTARI; ROLNIK, 2013, p.47).

A produção da subjetividade capitalística acontece de modo maquínico, desde a entrada da criança no mundo das línguas dominantes e utiliza para isso todos os modelos, tanto imaginários quanto técnicos onde ela se insere.

A subjetividade se constitui a partir de três funções principais: culpabilização, segregação e infantilização. A culpabilização, conforme Guattari (GUATTARI; ROLNIK, 2013), consiste em manter presente uma imagem referência que dá a base para os questionamentos existenciais sobre quem somos, em nome de quem ou com que autoridade opinamos. E para dar resposta a estes questionamentos o sistema só permite mediante agenciamentos coletivos.

Esses procedimentos de culpabilização são produzidos sistematicamente pelas instituições modelizantes, de formação da subjetividade de modo intrapsíquico. A segregação por sua vez, instaura sistemas de hierarquia insconsciente, sistemas de valores e disciplinarização. Guattari (GUATTARI; ROLNIK, 2013) ainda esclarece:

Tais sistemas dão uma consistência subjetiva às elites (ou pretensas elites) e abrem todo um campo de valorização social, onde os diferentes indivíduos e camadas sociais terão que se situar. Essa valorização capitalística se inscreve essencialmente não só contra os sistemas de valor de uso, como Marx descreveu, mas também contra todos os modos de valorização do desejo e todos os modos de valorização das singularidades (p. 50).

Em consonância com esta função está a infantilização quando pensam por nós, organizam por nós, tanto a vida em sociedade quanto a produção. E assim o autor a exemplifica: 
A infantilização - como a das mulheres, dos loucos, de certos setores sociais ou de qualquer comportamento dissidente - consiste em que tudo o se faz, se pensa ou se possa vir a fazer ou pensar seja mediado pelo Estado. Qualquer tipo de troca econômica, qualquer tipo de produção cultural ou social tende a passar pela mediação do Estado (GUATTARI, 2013, p. 50).

A ordem capitalística se projeta no mundo e na realidade psíquica, de modo a se inserir nas relações humanas e nas suas reproduções inconscientes. Para Guattari e Rolnik (2013), o ser humano aceita isto porque acredita que esta ordem do mundo não pode ser alterada. Qualquer tentativa de romper com o estabelecido é amplamente rechaçada:

Tudo que é do domínio da ruptura, da surpresa e da angústia, mas também do desejo, da vontade de amar e de criar, deve se encaixar de algum jeito nos registros de referências dominantes. Há sempre um arranjo que tenta prever tudo que possa ser da natureza de uma dissidência do pensamento e do desejo. Há uma tentativa de eliminar aquilo que eu chamo de processos de singularização (GUATTARI; ROLNIK, 2013, p. 52).

Na mesma obra que foi produzida em co-autoria com Rolnik, ela aponta a importância de Deleuze e Guattari na discussão do sistema capitalista porque ambos vislumbram os movimentos sociais da atualidade como pontos de ruptura que atacam a lógica do sistema. A estes pontos de ruptura eles chamam de revoluções moleculares. Estes movimentos são na verdade processos de singularização (GUATTARI; ROLNIK, 2013).

\subsubsection{As revoluções moleculares}

Os movimentos sociais tentam construir novos processos de subjetivação originais e singulares. Para os autores, Guattari e Rolnik (2013), há no planeta imensas áreas que estão em processo de reapropriação da subjetividade. Grupos que procuram operar um trabalho próprio de semiotização, de cartografia, buscando com isso, novas relações e novas alianças.

Esta reapropriação é um processo de singularização que capta os elementos da realidade e constrói outras referências, rompendo com a dependência do poder global. Com esta ruptura, os grupos em movimento tornam-se capazes de ler sua própria situação no mundo e criar a partir daí nova realidade. 
No estudo desta tese, por exemplo, no nível macro temos o movimento de mulheres e dentro desse universo, as revoluções moleculares desencadeadas, por exemplo, pelo Portal Blogueiras Feministas e em nível micro o blog Sapatilhando. A partir dessa percepção podemos detalhar, segundo Guattari (GUATTARI; ROLNIK, 2013), os níveis das revoluções moleculares: infrapessoais, pessoais, e interpessoais. Assim, podemos entender com maior clareza quando o autor conceitua esta revolução. "A revolução molecular consiste em produzir as condições não só de uma vida coletiva, mas também da encarnação da vida para si próprio, tanto no campo material quanto no campo subjetivo" (GUATTARI; ROLNIK, 2013, p. $55)$.

Há para o autor diferentes processos de singularização, porque lidamos com um devir diferencial. Devir que sinaliza uma vontade em potência. Um desejo de vida, de criatividade, de amor. Vemos, portanto, no blog Sapatilhando um vetor de singularização, como denomina Guattari (2013), porque os processos de individuação são microprocessos revolucionários que permitem ao desejo se manifestar.

Dito isto, o autor deixa claro que a maior oposição às revoluções moleculares somos nós mesmos. E afirma contundentemente:

Se levarmos isso em conta, teremos de reconhecer que o inimigo não está só nos imperialismos dominantes. Ele está também em nossos próprios aliados, em nós mesmos, nessa insistente reencarnação dos modelos dominantes, que encontramos não só nos partidos mais queridos ou nos líderes que nos defendem da melhor maneira possível, mas também em nossas próprias atitudes, nas mais diversas ocasiões (GUATTARI; ROLNIK, 2013, p. 57).

Ouvimos portanto, a fala de Guattari sobre a subjetivação no seio do sistema capitalístico e as possibilidades de contra-agenciamento e acreditamos que no e pelo discurso dialógico encontramos as ferramentas para a construção desse movimento. Daí a importância de chamarmos O Círculo Bakhtiniano para a conversa. 


\subsubsection{O Círculo de Bakhtin - a dialogia como processo educativo}

Mikhail M. Bakhtin é hoje considerado um dos principais pensadores do século XX. Conhecido como teórico da literatura, da linguagem e do discurso e, mais recentemente (em especial fora do Brasil), como filósofo, esboçou entre 1920 e 1924 uma filosofia do ato ético que dialoga com uma multiplicidade de filósofos, de Aristóteles a autores do século XX (SOBRAL, 2009). Sem dúvida, os trabalhos do Círculo se constituiu em uma revolução epistemológica sem precedentes.

Indagar-se sobre os conceitos na obra de Mikhail Bakhtin é sempre um desafio, pois sabe-se que aí está tudo em movimento permanente e não há terreno sólido para as construções formais. Mesmo porque, se há alguma coisa que caracterize o seu pensamento, essa alguma coisa é uma adesão ferrenha à filosofia do movimento. Nada é, em sua obra, definitivo, nada está estabelecido permanentemente, tudo oscila com as alterações do quadro histórico, em que as ações humanas se desenrolam. Bakhtin pretende, no fundamental, entender o exercício da linguagem humana por parte dos indivíduos. O que Saussure excluiu do estudo da linguística é exatamente o que atrai as atenções de Bakhtin. Para ele, o ser humano é a dialogia, porque estar no mundo é estar em interação:

\footnotetext{
Eu me conheço e chego a ser eu mesmo só ao me manifestar para o outro, através do outro e com a ajuda do outro. Os atos mais importantes que constituem a autoconsciência se determinam por relação a outra consciência. E todo interno não se basta por si mesmo, está voltado para o exterior, está dialogizado, cada vivência interna chega a colocar-se sobre a fronteira, se encontra com o outro, e neste intenso encontro está toda sua essência. O mesmo ser do homem tanto interior quanto exterior, representa uma comunicação profunda (BAKHTIN, 1997, apud SILVESTRI, 1993, p. 104).
}

Daí porque Bakhtin não construiu sua obra sozinho, ele trabalhou em grupo, olhando a vida real, onde de fato a linguagem acontece. Ele dialoga mais frequentemente com Volochinov, sobre os conceitos que interessam para nosso trabalho.

Brait e Campos (2009) apontam a questão das assinaturas e da composição do Círculo como algo que tem gerado muitas polêmicas, dúvidas em relação à autenticidade de conceitos genuinamente bakhtinianos, entretanto, isto 
não invalida em nada a riqueza da discussão sobre a linguagem humana desencadeada pelo Círculo.

\subsubsection{O Círculo bakhtiniano - a concepção de linguagem}

A discussão sobre a linguagem é um dos temas centrais dos estudos linguísticos. Os estudos do Círculo de Bakhtin em muito contribuíram para a inovação e criação de conceitos neste campo.

Entre os anos de 1929 a 1935 Bakhtin e Voloshinov (2009; 2010a) desenvolveram teorias acerca do dialogismo e do diálogo. Apesar de pairar sobre estas produções uma discussão sobre autoria, existe um encadeamento de ideias que ora pendem para uma perspectiva sociológica, ora pendem para teses de fenomenologia.

Vários estudiosos apontam a autoria colaborativa na produção científica do Círculo, apesar de eles, os integrantes, nunca terem se denominado como Círculo.

As obras fundantes para entendermos os conceitos que destacamos dos estudos bakhtinianos são: Marxismo e Filosofia da Linguagem (2009; 2010), A estrutura do enunciado (1981), O discurso na vida e o discurso na Arte, Para uma Filosofia do Ato (2003) e Estética da criação verbal (2010a).

Tanto Bakhtin quanto Voloshinov fazem duras críticas ao formalismo russo nesta primeira obra citada, tendência que na Teoria Literária buscava discutir a produção artística fora da vida que a produz, concebendo a língua como a palavra abstrata a ser moldada. Para Bakhtin e Voloshinov (2010) consideram a palavra um fenômeno ideológico por excelência.

Portanto, é na relação com a alteridade mediante o discurso dialógico que os sujeitos vão se constituindo socialmente. Assim, a afirmativa de Vidon (2009) de que também Bakhtin não concebe o sujeito do discurso como um ente psicológico dotado de razão e linguagem e muito menos, origem do todo enunciativo, vem corroborar com o pensamento de Voloshinov $(1981 ; 1993)$. 
É importante para a discussão dos conceitos bakhtinianos, entendermos o porquê de ele considerar o texto como objeto das Ciências Humanas. Faraco (2007), resume dos vários textos do autor, os elementos que transcrevemos a seguir:

Quanto ao objeto, o texto se define como:

A - objeto significante ou de significação, isto é, o texto significa. De um lado opõe-se, assim, "coisa" a "signo"; de outro, fica claro que as ciências humanas se preocupam com os processos de significação. Não se trata, portanto, de construir o objeto das ciências humanas a partir dos estudos linguísticos ou de pensá-lo como um sistema de signos, a exemplo da semiologia dos anos sessenta;

$B$ - produção da criação ideológica ou de uma enunciação, com tudo que está subtendido: contexto histórico, social, cultural, etc. Em outras palavras, o texto não existe fora da sociedade, só existe nela e para ela e não pode ser reduzido à sua materialidade linguística ou dissolvido nos estados psíquicos daqueles que o produzem ou o interpretam;

$\mathrm{C}$ - dialógico: já como consequência das duas características anteriores, o texto é constitutivamente dialógico; define-se pelo diálogo entre os interlocutores e pelo diálogo com outros textos, e só assim dialogicamente, constrói-se sua significação.

$D$ - único, não reproduzível: os traços mencionados fazem do texto um objeto único, não reiterável ou repetível (FARACO, 2007, p. 23).

O conjunto da obra do Círculo discute diversos conceitos que fundamentam a concepção de linguagem. Para este trabalho, deter-nos-emos apenas nos conceitos de Interação Verbal e Dialogismo, por entendermos serem estes centrais para a análise do nosso corpus de pesquisa.

\subsubsection{A interação verbal}

Para Bakhtin e Voloshinov (2009), a interação verbal é a realidade fundamental da língua, porque a linguagem, por sua natureza, comunica se dirigindo a outro. Ambos inseridos em um contexto sócio-histórico. Por ter esse entendimento, - Círculo dedicou toda sua reflexão ao projeto de construir paulatinamente uma filosofia da linguagem fundada na sua base comunicacional.

Para o Círculo, a comunicação é a realização concreta da interação verbal porque é a maneira do sujeito expressar-se na relação com um outro. Nessa relação, portanto, o eu só existe em relação ao outro e desta forma, configura-se a dinâmica da interação verbal e discursiva (BAKHTIN; VOLOSHINOV, 2009).

Dito isto, fica claro que o outro é uma categoria central e não deve ser entendido como passivo, assumindo um lugar ativo e responsivo: 
Toda compreensão da fala viva, do enunciado vivo, é de natureza ativamente responsiva (embora o grau desse ativismo seja bastante diverso); toda compreensão é prenhe de resposta, e nessa ou naquela forma a gera obrigatoriamente: o ouvinte se torna falante (BAKHTIN, 2009, p. 271).

A linguagem é, sob este ponto de vista, a expressão de um em relação ao outro, em determinado momento sócio-histórico, situado, portanto, tatuado em uma temporalidade como evento único e irrepetível.

Por isso, para Bakhtin se a concepção de linguagem é dialógica, se as ciências humanas têm método e objeto dialógicos, o homem e a vida também o são. Todorov (1981), estudioso bakhtiniano, aponta que no texto sobre a obra de Dostoiévski, o autor afirma: "[...] o ser mesmo do homem é uma comunicação profunda. Ser significa comunicar-se. [...] Viver significa participar de um diálogo, interrogar, escutar, responder, estar de acordo, discordar etc." (TODOROV, 1981, p.318).

Esta atividade pode ser entendida, a partir destas características como uma enunciação concreta que nasce, vive e morre no processo da interação social entre os participantes da enunciação:

Quando nós cortamos o enunciado do solo real que o nutre, nós perdemos a chave tanto de sua forma quanto de seu conteúdo - tudo que nos resta é um invólucro linguístico abstrato ou um esquema semântico igualmente abstrato (a banal ideia da obra, com a qual lidaram os primeiros teóricos e historiadores da literatura) - duas abstrações que são inconciliáveis entre si, porque não há base concreta para sua síntese viva (VOLOSHINOV, 1993, p. 122-123).

Os interlocutores desta enunciação concreta são reais e sóciohistoricamente situados, portanto, a linguagem trabalha com um signo de natureza ideológica, com a capacidade de refletir e refratar a realidade. Isto se dá porque

[...] ele pode distorcer essa realidade, ser-lhe fiel, ou apreendê-la de um ponto de vista específico, etc. Todo signo está sujeito aos critérios de avaliação ideológica (isto é, se verdadeiro, falso, correto, justificado, bom, etc.). (BAKHTIN; VOLOSHINOV, 2009, p. 32)

Como os participantes da comunicação viva não são passivos frente à linguagem, a fala viva e cotidiana é de natureza dinâmica e responsiva. Na realidade, todo aquele que ouve, fala e vice-versa. Nesta atividade interativa está contida a visão de mundo, a vivência, o sentir e um estar no mundo. Daí Bakhtin 
(1993) afirmar que "[...] a palavra da língua é uma palavra semialheia. Ela só se torna própria quando o falante a povoa com sua intenção, com seu acento, quando a domina através do discurso, torna-a familiar com sua orientação semântica e expressiva" (p. 100).

Neste movimento de interação social, os sujeitos constroem seus discursos por meio das próprias palavras e das palavras de outros sujeitos. Palavras estas que ganham significação no processo de seu discurso interior e na exteriorização disso, em contato com o discurso do outro, novos efeitos de sentido são gerados. Ou seja, as condições de produção do discurso são fundamentais para sua composição. Para Bakhtin, "[...] a língua vive e evolui historicamente na comunicação verbal concreta, não no sistema abstrato das formas na língua, nem no psiquismo individual dos falantes" (BAKHTIN; VOLOSHINOV, 2009, p. 214).

Esta concepção interacionista e sócio-histórica da linguagem apresentada por Bakhtin possui princípios claros: o sujeito social existe na relação situada social e historicamente com o outro na interação verbal; na unidade das diferenças entre interlocutores, nas imagens que constroem de si e as construídas socialmente e na discursividade, naquilo que se constrói mediante os gêneros do discurso.

Em outras palavras, nas situações de interação é que a palavra é selecionada, tendo em vista os interlocutores, porque é por meio dela que o discurso toma forma e a situação enunciativa se concretiza. Como explicam Bakhtin e Voloshinov (2010):

A palavra dirige-se a um interlocutor: ela é função da pessoa desse interlocutor: variará se se tratar de uma pessoa do mesmo grupo social ou não, se esta for superior ou inferior na hierarquia social, se estiver ligada ao locutor por laços sociais mais ou menos estreitos (pai, mãe, marido e etc.). (p. 112)

É nesse processo social de interação verbal, nesta sociabilidade que a palavra se significa, isto é, a palavra ganha significado no contexto de uso e deixa de ser forma para se tornar signo. Signo ideológico nos pressupostos do Círculo de Bakhtin.

Os sentidos, portanto, são construídos ou desconstruídos conforme um processo de seleção dos interlocutores, nas suas possibilidades de compreensão. Para Bakhtin e Voloshinov (2004) isto quer dizer: 
$\mathrm{Na}$ realidade toda palavra é composta de duas faces. Ela é determinada tanto pelo fato de que procede de alguém, como pelo fato de que se dirige para alguém. Ela constitui justamente o produto da interação do locutor e do ouvinte. Toda palavra serve de expressão de um em relação a um outro, isto é, em última análise, em relação à coletividade. A palavra é uma espécie de ponte lançada entre eu e os outros. Se ela se apoia em mim numa extremidade, na outra apoia-se sobre o meu interlocutor. A palavra é um território comum do locutor e do interlocutor (p. 113).

\subsubsection{Dialogismo}

Como vimos no trecho anterior, o diálogo só acontece na cumplicidade entre locutor e interlocutor, entre sujeitos. Quando esses sujeitos escolhem as palavras que vão constituir seus discursos, estas escolhas carregam valores representativos daquela situação enunciativa.

A palavra é interna e externa ao sujeito. Interna quando constitui seu mundo interior, como diria Vygotsky (1993), um microcosmo da consciência humana, orientando suas ações e constituindo sua consciência nos processos de interação.

A palavra é externa quando são confrontadas as palavras da consciência com as palavras circundantes na realidade - os signos ideológicos. Desse confronto surge a interiorização da palavra, como se retornasse nova. Desse processo nasce a interpretação do mundo pelos sujeitos.

Para Bakhtin e Voloshinov (2004), o centro organizador de toda enunciação, de toda expressão, não é interior, mas sim exterior e está situado no meio social que envolve o indivíduo. Desta maneira, pode se inferir que o homem evoluirá em direção ao seu caráter social quanto mais souber operar com a linguagem, atingindo aquilo que Vygotsky (1993) chama de funções mentais superiores.

Já que se trata de linguagem e não da língua a unidade básica do discurso é o enunciado e não o signo. O enunciado é uma unidade mais complexa que exige a presença de um enunciador, seja quem fala, seja quem escreve e um receptor, que ouve ou lê.

O discurso por sua vez, é o conjunto de enunciações concretas e tem como característica ser responsivo. Para Bakhtin (2006), o discurso só pode existir 
de fato na forma de enunciações concretas de determinados falantes, sujeitos do discurso. Assim, ele esclarece:

Os limites de cada enunciado, como unidade da comunicação discursiva, são definidos pela alternância de sujeitos do discurso, ou seja, pela alternância dos falantes. Todo enunciado - da réplica sucinta (monovocal) do diálogo cotidiano do grande romance ou tratado científico tem por assim dizer, um princípio absoluto e um fim absoluto: antes do seu início, os enunciados dos outros; depois do seu término, os enunciados responsivos de outros (ou ao menos uma compreensão ativamente responsiva silenciosa do outro ou, por último, uma ação responsiva baseada nesta compreensão). (BAKHTIN, 2006, p. 275)

Deste modo podemos entender que dialogismo é o processo que retrata a relação dos enunciados que necessariamente são respostas a enunciados anteriores e que se abrem a respostas de enunciados vindouros.

Assim, o diálogo vivo, real e humano é bem definido quando Bakhtin (2010) afirma:

O discurso vivo e corrente está imediatamente determinado pelo discursoresposta futuro: ele é que provoca esta resposta, pressente-a e baseia-se nela. Ao se constituir na atmosfera do "já dito", o discurso é orientado ao mesmo tempo para o discurso-resposta que ainda não foi dito, discurso, porém, que foi solicitado a surgir e que já era esperado (p. 89).

Para o Círculo o processo dialógico se estrutura mediante vozes e lugares do discurso. E esta estruturação se faz necessário entender, porque o material de análise desta tese é um discurso hipertextualizado e também virtualizado. Portanto, um processo enunciativo responsivo, em constante movimento, ideologicamente estruturado e que lança mão de diversas linguagens, estéticas e também é polifônico.

Nas suas primeiras reflexões sobre a linguagem, na tentativa de esboçar uma teoria do conhecimento, Bakhtin (1993) já esclarece o que ele entende por enunciação enquanto interação:

A palavra integral não conhece um determinado objeto na sua globalidade. Só pelo fato de eu ter falado dele, a minha relação para com ele deixou de ser indiferente, tornando-se interessada e ativa. Por isso, a palavra, além de designar o objeto como algo que se torna presente, através da entonação (a palavra realmente pronunciada vem obrigatoriamente associada a determinada entonação que decorre do próprio fato de ser pronunciada), exprime ainda a minha atitude valorativa em relação ao objeto, positiva ou negativa, e, com isso, o põe em movimento, fazendo dele um elemento de eventualidade viva (BAKHTIN, 1993, p. 32-33). 
Polifônico, por sua vez, porque várias vozes falam no interior de um enunciado, de um texto, ou do discurso:

\begin{abstract}
Por mais monológico que seja um enunciado (uma obra científica ou filosófica, por exemplo), por mais que se concentre em seu objeto, ele não pode deixar de ser também, em certo grau, uma resposta ao que já foi dito sobre o mesmo objeto, sobre o mesmo problema, ainda que este caráter de resposta não receba uma expressão externa bem perceptível. A resposta transparecerá nas tonalidades do sentido, da expressividade, do estilo, nos mais ínfimos matizes da composição. As tonalidades dialógicas preenchem um enunciado e devemos levá-las em conta se quisermos compreender até o fim o estilo do enunciado (BAKHTIN, 2010a, p. 317).
\end{abstract}

Todo diálogo, portanto, sempre pressupõe alguém diante de quem se dialoga ou com quem se dialoga. Não são interlocutores ou pessoas que dialogam, são seus discursos que dialogam. Nesse processo sempre construímos um enunciado, a partir de uma referência axiológica, isto é, um conjunto de valores que darão consistência ao que dizemos.

No lugar da enunciação, conforme os estudos bakhtinianos, estão presentes diversas vozes. A voz do locutor, que é o sujeito do enunciado. Há também a voz do autor, sujeito da enunciação. No lugar do destinatário, há a presença do destinatário real, aquele que lê e interpreta o texto. Há também o destinatário suposto, aquele idealizado que seria para quem se elaborou o discurso, portanto, de certa forma, ele é co-autor do texto, por consequente do enunciado e por fim o sobredestinatário, que é aquele que interpreta e reconstrói o texto no futuro, em outro contexto sócio-cultural.

A todos esses elementos Bakhtin (2010a) dá o nome de vozes, portanto, a enunciação ou o discurso obrigatoriamente é dialógico.

Segundo Marcuzzo (2008), o conceito de dialogismo em Bakhtin não significa diálogo face a face, uma vez que o interlocutor só existe enquanto discurso. Conforme esta autora, o termo diálogo/dialogismo é utilizado de três maneiras diferentes na obra de Bakhtin (apud MORSON; EMERSON, 2008): o termo pode ser considerado como a descrição da linguagem que torna todos os enunciados, por definição, dialógicos, pode ser também a expressão que define um tipo específico de enunciado, oposto àqueles de caráter monológico e também pode significar uma visão de mundo e da verdade em uma conceituação global. 
Não vamos, em nosso estudo, nos deter em analisar discursos monológicos ou dialógicos, segundo a visão da sociolinguística, mas sim usarmos essa categoria da dialogia como manifestação discursiva relacionada à atividade humana que apresenta atitudes valorativas dos participantes.

Conforme Brait (2006), ao estudar as relações dialógicas, Bakhtin cria a Metalinguística, uma ciência que engloba a Linguística porque se encarrega de fazer uma análise externa das relações geradas pela linguagem.

\begin{abstract}
O trabalho metodológico, analítico e interpretativo com textos e discursos se dá, como se pode observar nessa proposta de criaçãode uma nova disciplina, ou conjunto de disciplinas, herdando da Linguística a possibilidade de esmiuçar campos semânticos, descrever e analisar micro e macro organizações sintáticas, reconhecer, recuperar e interpretar marcas e articulações enunciativas que caracterizam o(s) discurso(os) e indiciam sua heterogeneidade constitutiva, assim como a dos sujeitos aí instalados. A partir do diálogo com o objeto de análise, chegar ao inusitado se sua forma de ser discursivamente, à sua maneira de participar ativamente de esferas de produção, circulação e recepção, encontrando sua identidade nas relações dialógicas estabelecidas com outros discursos, com outros sujeitos (BRAIT, 2006, p.58).
\end{abstract}

Nesse sentido, podemos ver o processo de leitura, também, na sua dimensão compreensiva. Para o Círculo, ler é responder, uma vez que a linguagem tem um caráter responsivo. Os atos da escrita e da leitura são atividades constitutivas da linguagem.

Como a linguagem é um processo constante e dialógico, segundo o Círculo, também podemos considerar a leitura como um processo integrante desse primeiro que envolve a construção de sentido do texto e a constituição dos sujeitos que participam das situações de interação. Foi neste entendimento que outros autores brasileiros foram estudando e aprofundando os estudos bakhtinianos.

Para Marcushi (2008), em uma perspectiva bakhtiniana, a compreensão é uma forma de agir sobre o mundo na relação com o outro dentro de uma cultura e em uma sociedade.

Por isso, também entendemos no nosso trabalho, a leitura como dialógica porque a compreensão é determinada pela situação única de uso da linguagem, daí decorre os sentidos serem únicos, porque 
preciso. Compreender sua significação numa enunciação particular (BAKHTIN; VOLOSHINOV, 2009, p.94).

Ler, portanto, é compreender e compreender uma resposta. Uma resposta feita de palavras que são nossas e podem ser de outros no futuro como foram no passado, antes de considerarmos como nossas. As situações de interação no espaço e no ciberespaço demandam múltiplos letramentos, porque são múltiplas as linguagens. Linguagens agora ancoradas em outro suporte - a internet- que deu tanto movimento à palavra que esta se tornou líquida como a nomeia Santaella (2007) em seus estudos.

Trata-se da linguagem digital, que permite a produção e a manipulação de quaisquer elementos de texto, som e imagem, incluindo uma ampla margem de possibilidades, tais como a gráfica e a animação computadorizadas, imagens digitalizadas, esculturas cibernéticas, shows de laser controlados e manipulados por computador, eventos cinéticos, telecomunicacionais e muito mais (SANTAELLA, 2007, p. 38).

O estudo da subjetividade humana com o advento das novas tecnologias digitais precisa também de outras lentes que discutam a linguagem e os novos gêneros textuais advindos deste fenômeno midiático.

Para nosso estudo é preciso entender o processo de construção do sujeito feminino, enquanto autor que lança mão da linguagem multimodal e hipertextual. Como dialoga com seu leitor, ou sobredestinatário, como entende Bakhtin(2003), ao analisar o lugar da leitura. Este leitor pode ser assim considerado, também interlocutor, porque ao comentar o hipertexto, ele também se autoriza a produzir textos, a partir das narrativas lidas. Ambos, autor e leitor, ao se colocarem em interlocução, produzem de algum modo, configurações subjetivas e novos sentidos.

Segundo Faraco et al. (1988), para os estudos textuais tornou-se fundamental a ordem interna do texto, porque ele passou a ser visto, na contemporaneidade, como uma forma atualizadora de códigos culturais que transcendem a autoria e, portanto, devem ser estudados em si, dispensando-se a necessidade de referência a quem está escrevendo. Em consequência disso, segundo Barthes (1998): "[...] vai-se também perceber o texto não como uma sequência de palavras a produzir um significado único, mas um espaço de 
dimensões múltiplas, onde se casam e se contestam escrituras variadas, das quais nenhuma é original" (p. 69).

Como se pode ver, é o próprio escrever que está sofrendo um processo de reconceitualização. A escrita está deixando de ser, um fazer individual e passa cada vez mais e em especial no ciberespaço, a ser um jogo interativo e colaborativo.

Para Faraco et al (1998), os textos são infinitamente criados pelos leitores no processo de leitura. E esse processo é sempre associativo porque na leitura associamos ao texto outras ideias, outras imagens, outros textos e outras significações.

Assim como Bakhtin, Faraco et al (1998) vê a linguagem enquanto prática discursiva:

\begin{abstract}
A dinâmica sócio-histórica das comunidades humanas, (inclusive as virtuais), cria múltiplos horizontes interpretativos da realidade, cada um constituindo uma certa posição avaliativa da realidade. [...] Essas línguas sociais (também chamadas de vozes sociais) são uma espécie de tecido em que se entrelaçam palavras e valores; são conjuntos difusos de visões de mundo (sistemas sociais de crenças) e elementos verbais (p.165).
\end{abstract}

Segundo o autor, o falante se individualiza enquanto discurso na interação viva com estas vozes sociais: "Autorar, nessa perspectiva, é orientar-se na atmosfera heteroglótica; é assumir uma posição estratégica no contexto da circulação e da guerra das vozes sociais; é explorar o potencial de tensão criativa da heteroglossiadialógica"13 (FARACO ET AL, 1998, p. 169).

Para os estudos da Teoria Literária, no século XX, ao discutir o hibridismo dos gêneros literários, em especial a forma como os textos eram percebidos pelos leitores, Jauss (1979) vai de certa forma desencadear a ampliação do conceito de texto e de leitor, abrindo com isso, os horizontes para uma nova escrita tecida em camadas que vão imbricar palavra, imagem e posteriormente som.

Ganha corpo também nesse período, os estudos linguísticos sobre o texto multimodal, aquele que não se basta em ser apenas escrita. Essa nova escrita gera também uma nova leitura.

\footnotetext{
${ }^{13} \mathrm{Em}$ Faraco et al (2007), o autor afirma que Bakhtin ocupa-se da diversidade de vozes, das línguas e dos tipos discursivos. Foram os tradutores franceses daquele autor que preferiram Heterologia ou pluridiscursidade para tratar da variação linguística.
} 
O universo digital, na contemporaneidade, integra várias linguagens. Com isso os textos ganham elementos gráficos de navegação; o sentido deixa de ser restrito ao processamento dos elementos verbais e considera todas as linguagens envolvidas no processo comunicativo.

Quando a multimodalidade se manifesta ou se concretiza no ciberespaço, ela ganha uma nova dimensão, podendo se consubstanciar em uma metáfora da mente humana. Com isso, Guattari, Bakhtin, Lévy e Santaella se aproximam naquilo que discutem sobre a subjetividade e linguagem como processos dinâmicos e relacionados.

\title{
2.2.3 As teorias de Lévy e Santaella - cartografando novos territórios e novas linhas
}

\begin{abstract}
A arca do primeiro dilúvio era única, estanque, fechada, totalizante. As arcas do segundo dilúvio dançam entre si. Trocam sinais. Fecundam-se mutuamente. Abrigam pequenas totalidades, mas sem nenhuma pretensão universal. Apenas o dilúvio é universal. Mas ele é intotalizável. É preciso imaginar um Noé modesto.
\end{abstract}

Pierre Lévy

Para debruçar-mo-nos sobre o blog Sapatilhando e entendê-lo no contexto da Blogosfera, chamamos para este estudo dois teóricos que discutem a linguagem no ciberespaço, em uma perspectiva antropológica e comunicacional, ambos também desenvolvem seus trabalhos em ambiente colaborativo com outros autores e com alunos.

Pierre Lévy especializou-se em abordagens hipertextuais quando lecionou na Universidade de Ottawa, no Canadá. Após sua graduação, preocupou-se em analisar e explicar as interações entre Internet e Sociedade. Lévy também pesquisa a inteligência coletiva focando em um contexto antropológico, e é um dos principais filósofos da mídia atualmente.

Lucia Santaella é uma das pesquisadoras brasileiras com maior reconhecimento no meio acadêmico, não só nacional como mundial. É professora titular no programa de pós-graduação em Comunicação e Semiótica e coordenadora do programa de pós-graduação em Tecnologias da Inteligência e Design Digital da 
Pontifícia Universidade Católica de São Paulo (PUC-SP). Tem mais de 20 livros publicados, mais de 200 artigos em periódicos nacionais e internacionais.

O reconhecimento acadêmico e intelectual da professora pós-doutora é inegável, principalmente na área de semiótica e comunicação. Seu último livro, Comunicação ubíqua: repercussões na cultura e na educação, lançado em 2013, traz importantes reflexões e inquietações sobre a área da educação.

Para Santaella (2003), a revolução digital não está apenas transformando os formatos de comunicação. Entre outros aspectos, seus estudos apontam para a necessidade permanente de reflexão sobre as modificações pelas quais o ser humano vem passando em contato com as tecnologias, modificações "[...] não apenas mentais, mas também corporais, moleculares" (SANTAELLA, 2003, p. 31).

\subsubsection{O hipertexto - a nova textualidade}

Quando o cientista Vannevar Bush, na década de 1940, concebeu a ideia de hipertexto, pensava na necessidade de substituir os métodos existentes de disponibilização e recuperação de informações ligadas especialmente à pesquisa acadêmica, que eram lineares, por sistemas de indexação e arquivamento que funcionassem por associação de ideias, seguindo o modelo de funcionamento da mente humana. $O$ cientista preocupava-se também com a criação de um sistema que fosse como uma máquina poética, algo que funcionasse por analogia e associação, máquinas que capturassem o brilhantismo anárquico da imaginação humana (LANDOW, 1997).

A ideia inicial de Bush foi conceituada como hipertexto 20 anos depois de seu artigo fundador, ligada à concepção de um grande sistema de textos que pudessem estar disponíveis em rede. Segundo Lawdow (1997), na década de 1960, o cientista Theodor Nelson sonhava com um sistema capaz de disponibilizar um grande número de obras literárias, com a possibilidade de interconexão entre elas.

Criou, então, o projeto denominado Xanadu para disponibilizar toda a literatura do mundo, numa rede de publicação hipertextual universal e instantânea, que funcionava como um imenso sistema de informação e arquivamento. $O$ hipertexto deveria ser um enorme arquivo virtual. Com estas proporções o projeto 
não atingiu seus objetivos, mas sem dúvida foi o início para tudo que vivenciamos hoje quando temos acesso a um número de textos e obras em formato eletrônico nunca antes pensado.

O espaço cibernético, segundo Lévy (2000), é o terreno onde está funcionando a humanidade hoje, porque nele se dão processos de interação que envolvem os planos econômico, político e científico. E com o passar do tempo também será fundamental para a Pedagogia, para a Arte e para a Estética conclui ele,

\begin{abstract}
Com o espaço cibernético, temos uma ferramenta de comunicação muito diferente da mídia clássica, porque é nesse espaço que todas as mensagens se tornam interativas, ganham uma plasticidade e tem uma possibilidade de metamorfose imediata. E aí, a partir do momento em que se tem acesso a isso, cada pessoa pode se tornar uma emissora, o que obviamente não é o caso de uma mídia como a imprensa ou a televisão. [...] O espaço cibernético introduz o terceiro tipo, com um novo tipo de interação que poderíamos chamar de Todos e Todos, que é a emergência de uma inteligência coletiva. Do interior do espaço cibernético, encontramos uma variedade de ferramentas, de dispositivos, de tecnologias intelectuais (LÉVY, 2000, p.14).
\end{abstract}

Neste espaço, segundo Lévy (2000), há um potencial de mensagens em movimento imenso e com isso, recupera-se a possibilidade de ligação com um contexto que tinha desaparecido com a escrita e com todos os suportes textuais estáticos. No espaço cibernético pode-se reencontrar uma comunicação viva da oralidade de maneira infinitamente mais ampliada e complexificada. É o caso do hipertexto e da hipermídia que coloca informação em rede. Não é mais o leitor, segundo Lévy (2000) que vai se deslocar diante do texto, mas o texto que, como em um caleidoscópio, vai se dobrar e se desdobrar diferentemente diante de cada leitor.

Tanto a escrita como a leitura vão mudar o seu papel. O próprio leitor vai participar da mensagem na medida em que ele não vai estar ligado a um aspecto. O leitor passa a participar da própria redação do texto à medida que ele não está mais na posição passiva diante de um texto estático, uma vez que ele tem diante de si não uma mensagem estática, mas um potencial de mensagem. Dessa forma, o espaço cibernético introduz a ideia de que toda leitura é uma escrita em potencial (LÉVY, 2000, p.15).

Com isso, estamos assistindo, ainda segundo o autor, uma desterritorialização dos textos, eles se tornam fluxos porque o suporte não é fixo e por estar no espaço cibernético, eles têm a possibilidade de interação como qualquer outro elemento presente. Desta forma, todos os textos fazem parte de um 
único texto infinito, um hipertexto de autoria coletiva: "É como se todas as músicas passassem a fazer parte de uma mesma polifonia virtual e potencial, como se todas as músicas fizessem parte de uma só música, também ela virtual e potencial” (LÉVY, 2000, p.15).

Além da desterritorialização dos textos, também estamos vivendo a desterritorialização da biblioteca. Segundo o autor, seria uma volta às origens, em que o portador do saber era a comunidade viva, mas agora de uma forma muito ampliada e diferenciada. É como se o coletivo fosse novamente portador de todo conhecimento. "Não se trata mais de uma enciclopédia, mas de uma espécie de plasmopédia, isto é, um espaço de saber vivo e dinâmico” (LÉVY, 2000, p. 17).

O hipertexto constitui hoje a base da Internet. Quando acessamos um site, por exemplo, escolhemos o caminho que desejamos seguir e, ao clicar o mouse em determinadas frases ou palavras, novos textos nos saltam aos olhos. Esta estrutura textual permite que o leitor, ao escolher a sequência de leituras, seja coautor do texto, porque esta forma de organização textual permite a colaboração e a construção de outros infinitos textos e a alternância nas posições de autor/leitor como no caso dos blogs.

Desde o surgimento da ideia de hipertexto, este conceito está ligado a uma nova concepção de textualidade, em que a informação é disposta em um ambiente, no qual pode ser acessada de forma não-linear. Isto implica em uma textualidade que funciona por associação, e não mais por sequências fixas previamente estabelecidas.

Portanto, estamos diante de uma relação estreita entre linguagem e memória que altera significamente a relação do ser humano com o conhecimento. Em função disso consideramos pertinente a análise que Lévy (1995) faz desta relação:

- primeiro tempo, tempo da oralidade primária, quando o coletivo humano tinha uma identidade comum. Linguagem e memória, dois aspectos de um mesmo fenômeno.

- segundo tempo, tempo da escrita, momento de semi-objetivação da lembrança. O conhecimento começa a ser, em parte, separado do sujeito que o produz. A questão da verdade se constitui como principal preocupação da ciência humana.

- terceiro tempo, tempo da informatização. Tempo do afastamento radical da memória humana. A objetivação da memória atinge tal ponto que a questão da verdade começa a deixar de ser uma questão fundamental. Com a informática, a objetivação da memória se automatiza a tal ponto, 
tornando-se tão distante do corpo do indivíduo e dos hábitos coletivos, que vale questionarmos se a própria noção de memória é ainda pertinente ( $p$. 24).

Segundo Lévy (1993), sob o ponto de vista técnico, um hipertexto é um conjunto de nós ligados por conexões. Os nós podem ser palavras, páginas, imagens, gráficos ou partes de gráficos, sequências sonoras, documentos complexos que podem eles mesmos ser hipertextos. Do ponto de vista funcional, o autor afirma que um hipertexto é um tipo de programa para a organização de conhecimentos ou dados, a aquisição de informações e a comunicação. Há portanto, uma ligação em tudo.

Seja qual for a mensagem abordada, ela se conecta a outras mensagens, a comentários em constante evolução. Um texto qualquer é talvez o fragmento ignorado do hipertexto em constante movimento, que o envolve e - conecta a outros textos, servindo de mediador ou meio a uma comunicação recíproca, interativa e ininterrupta (LÉVY, 1999, p. 118- 119).

O hipertexto, também para Lévy (1993), pode ser definido como um documento digital composto por diversos blocos de textos interconectados através de links, que possibilitam o avanço da leitura de forma aleatória.

O texto na tela, portanto, não apresenta fronteiras radicalmente visíveis, mas sim possibilidades de embaralhar, entrecruzar, reunir textos que são inscritos na mesma memória. Lévy (2003, p. 41) afirma que "[...] a tela informática é uma nova 'máquina de ler', o lugar onde uma reserva de informação possível vem se realizar por seleção, aqui e agora, para um leitor particular".

Segundo Moura e Montovani (2012), observando a história da evolução do texto, podemos constatar várias mudanças na forma do ser humano se expressar e as várias formas de ler. Estas mudanças salientam a relação entre o corpo e o texto, os possíveis usos da escrita e as categorias intelectuais que asseguram a compreensão e as transformações no modo como o homem manifesta sua subjetividade.

Segundo as autoras, no livro impresso há uma ordem sequencial a ser seguida, em um primeiro momento determinada pelo autor e também pela organização estrutural e material. Embora possa ser lido aleatoriamente, ele estará sempre confinado a uma determinada dimensão física que o delimita. Em textos digitais isso não acontece (MOURA; MONTOVANI, 2012). O espaço da informação 
não se limita, abrindo-se em ramificações que permitem diversas navegações. A estrutura do texto pode ser como um complexo modelo molecular, no qual o leitor pode intervir: "Hoje o leitor pode intervir no centro do texto, na medida em que o suporte digital permite usos, manuseios e intervenções do leitor infinitamente mais numerosos e mais livres do que qualquer uma das formas antigas do livro" (CHARTIER, 1998, p.88).

A leitura mais ágil e sem limites do hipertexto, em relação ao texto, se deve à infinidade de links disponíveis. Estes mecanismos se conectam a outros hipertextos de forma não-linear e não-sequencial. É uma coleção de informações multimodais disposta em rede para a navegação rápida e intuitiva. Entre as principais características apresentadas para o hipertexto encontram-se as seguintes, segundo Koch (2005, p.64):

1. não-linearidade (geralmente considerada a característica central)

2. volatilidade, devida à própria natureza (virtual) do suporte;

3. espacialidade topográfica, por se tratar de um espaço de escritura/leitura sem limites definidos, não hierárquico, nem tópico;

4. fragmentariedade, visto que não possui um centro regulador imanente;

5. multisemiose, por viabilizar a absorção de diferentes aportes sígnicos e sensoriais numa mesma superfície de leitura (palavras, ícones, efeitos sonoros, diagramas, tabelas tridimensionais);

6. interatividade, devido à relação contínua do leitor com múltiplos autores praticamente em superposição em tempo real;

7. interatividade, em decorrência de sua natureza intrinsecamente polifônica e intertextual;

8. descentração, em virtude de um deslocamento indefinido de tópicos, embora não se trate, é claro, de um agregado aleatório de fragmentos textuais.

No texto eletrônico nenhum estado ou versão é definitivo porque a cada leitura de quem o acessa novos caminhos podem ser trilhados e uma nova cartografia de leitura pode ser definida. Os hipertextos são obras abertas e em movimento e à medida que são compartilhadas novas postagens pelos leitores, novas leituras podem ser realizadas.

Lévy (1993) complementa as considerações de Koch (2005), quando aponta algumas características básicas ou "princípios abstratos" do texto eletrônico, que são:

Princípio de metamorfose: a rede hipertextual encontra-se em constante construção e renegociação. Sua extensão, composição e desenho estão 
sempre em mutação, conforme o trabalho dos atores envolvidos, sejam eles humanos, palavras, sons, imagens, etc.

Princípio de heterogeneidade: os nós de uma rede hipertextual são heterogêneos; podem ser compostos de imagens, sons, palavras, etc. E o processo sociotécnico colocará em jogo pessoas, grupos, artefatos, com todos os tipos de associações que pudermos imaginar entre eles.

Princípio de multiplicidade e de encaixe das escalas: o hipertexto é fractal, ou seja, qualquer nó ou conexão, quando acessado, pode revelar-se como sendo composto por toda uma rede de nós e conexões, e assim, indefinidamente.

Princípio de exterioridade: a rede não possui unidade orgânica, nem motor interno. Seu crescimento e diminuição, composição e recomposição dependem de um exterior indeterminado, como adição de novos elementos, conexões com outras redes, etc.

Princípio de topologia: no hipertexto, tudo funciona por proximidade e vizinhança. O curso dos acontecimentos é uma questão de topologia, de caminhos. A rede não está no espaço, ela é o espaço.

Princípio de mobilidade dos centros: a rede possui não um, mas diversos centros, que são perpetuamente móveis, saltando de um nó a outro, trazendo ao redor de si uma ramificação infinita de pequenas raízes, rizomas, perfazendo mapas e desenhando adiante outras paisagens (LÉVY, 1993, p. 26).

As características próprias do hipertexto e as novas relações entre autor e leitor que este sistema está introduzindo, estão transformando radicalmente a comunicação. Na Internet, centenas de histórias em ficção interativa surgem a cada dia, centenas de blogs, de sites, povoando o ciberespaço e desafiando os cibernautas a empreenderem outro tipo de leitura, que aposta nas transformações do meio digital e na mudança de sensibilidade para o texto escrito e, portanto, há que se estudar a subjetividade e as manifestações do Ser nesse espaço que se organiza em uma dinâmica própria.

Para Lévy (1993) que discute as mudanças na sociedade humana após o surgimento das novas tecnologias, o paradigma tradicional colocava o sujeito como passivo e espectador do mundo, agora o sujeito é um coletivo que busca a remoção das fronteiras e a desterritorialização do conhecimento. Este descentramento, não mais restrito a muros e poucas pessoas, e que poderia resultar em um reconhecimento e valorização desta inteligência coletiva. Trata-se de uma abordagem do conhecimento onde o sujeito não é ignorado, diferente da concepção cartesiana, onde o objeto do conhecimento está à frente do sujeito.

Quando discute uma antropologia para o ciberespaço, Lévy (1993) aponta para uma relação fundada no sujeito/objeto do conhecimento, que rompe o processo poder/conhecimento. O sujeito participa na produção de significados a partir dos 
significantes que lhe são propostos, alimentando o binômio razão/emoção e, dessa forma, transformando a cultura de sua época. O autor destaca que o sujeito é transcendental, histórico, variável e indefinido. O sujeito nesta perspectiva é uma rede complexa, na qual os nós biológicos são redefinidos e mesclados por nós técnicos, semióticos, institucionais, culturais.

\subsubsection{O texto na era da mobilidade}

Santaella (2011) no seu livro Linguagens líquidas na era da mobilidade apresenta uma longa discussão sobre a evolução histórica do livro impresso à hipermídia e como o texto se configura em ambientes virtuais hipermidiáticos.

No primeiro capítulo, a autora trabalha com o sentido comum do texto, isto é, uma cadeia relativamente coesa e coerente de signos linguísticos. Esta escolha é proposital e não desconsidera as diversas teorias sobre texto e textualidade e muito menos a semiótica que expandiu este conceito também para outras linguagens. Uma pintura, por exemplo, pode ser um texto, uma melodia pode ser um texto, enfim, 0 texto não fica reduzido apenas à produção escrita no suporte papel. "Colocar esse sentido de texto em uma perspectiva histórica desde o aparecimento do livro, seu mais leal veiculador, até o advento das tecnologias digitais e da linguagem que lhes é própria, a hipermídia" (SANTAELLA, 2011, p.285).

Para Santaella (2011), a hipermídia é uma linguagem híbrida, mestiça e complexa. Ela integra texto, imagens diversas, fixas ou em movimento, sons variados, música e ruído. E esse hibridismo não é algo que surgiu abruptamente. $\mathrm{Na}$ verdade, é o resultado de um processo evolutivo que se intensificou com o surgimento da fotografia e do jornalismo.

A era das letras se estendeu do século XV ao XIX e o divisor de águas é o livro impresso que tira das mãos de alguns poucos a capacidade de leitura e amplia esse universo para muitos e a vida social e cultural se modifica completamente. Por outro lado, as limitações de tempo e transporte faziam com que as informações caducassem com facilidade. Com o telégrafo, esse problema é superado. Nesse esteio a invenção da fotografia acontece e com ela a explosão do jornal. A conexão entre esses nós propicia um acesso mais atualizado à informação. 
Do texto monosemiótico, afirma a autora, passa-se a intersemiose do jornal. Texto e imagem se entrelaçam ressignificando o conteúdo veiculado.

Este imbricamento foi se intensificando e com isso a complementariedade entre processos sígnicos diversos se dá. Essa mistura fez com que o texto do livro também sofresse alterações na sua formatação e diagramação. Abriu-se novos espaços na mancha gráfica das páginas. Para a autora, este fenômeno não enfraqueceu a existência do livro, e nem foi uma ameaça à sua existência. Não é, segundo ela, qualquer mídia que pode substituí-lo. Isto porque o surgimento de uma nova mídia refuncionaliza o papel cultural dos meios que a precederam:

Via de regra, um período inicial de impacto é seguido por uma readaptação gradativa, até que um novo desenho de funções se instale. O que a explosão do jornal germinou foram as sementes da cultura de massas que cresceu ainda mais com o desenvolvimento do cinema, poderosa extensão da fotografia. (SANTAELLA, 2011, p.288)

Desta forma se estabelecia o primado da imagem que ocupou a cena urbana e segundo a autora, alimenta a efemeridade dos desejos de sociedades de consumo frenético como as nossas. Mas a grande revolução foi sem dúvida, a chegada dos meios eletroeletrônicos e as redes de transmissão - o rádio e a televisão. Meios estes que abriram espaço para a oralidade e seus padrões semióticos presentes nos diálogos e nas falas.

No século $X X$, vimos a exacerbação dessa era e a consolidação da convivência e da mistura da escrita com a imagem e em paralelo também crescia enormemente a produção de textos impressos, contrariando as previsões de muitos analistas da literatura.

Santaella (2011) denomina esse hibridismo, de cultura das mídias. Esta cultura fez com que o texto saísse do papel, ganhasse o vídeo nos anos 80 (século $X X)$, um formato anterior à internet que conhecemos hoje e posteriormente esse texto já hibridizado é absorvido pela hipermídia, transformando-o de sólido para líquido no extremo da mobilidade.

Os processos de comunicação gerados pelas hipermídias são novos, interativos e dialógicos. De certa forma, materializa-se com as hipermídias a oralidade e a dialogia já indicados por Bakthin (2003), quando discute o ciclo criativo 
e infinito da enunciação. Além desses elementos que se agregam, é importante frisar o fato de que a linguagem digital também transcodifica códigos, linguagens e sinais:

[...] por ter a capacidade de colocar todas as linguagens dentro de uma raiz comum, a linguagem digital permite - sua proeza maior - que essas linguagens se misturem no ato mesmo de sua formação. Criam-se, assim, sintaxes híbridas. Miscigenadas. Sons, palavras que antes só podiam coexistir, passam a se coengendrar em estruturas fluídas, cartografias líquidas para a navegação com as quais os usuários aprendem a interagir, por meio de ações participativas, como em um jogo. Esse é o princípio da hipermídia que se instala no âmago da linguagem (SANTAELLA, 2011, p.294).

Com estas mudanças profundas na linguagem, transformações acontecem na cultura, na cognição e na comunicação, alterando de fato o modo de produção do conhecimento, arte e informação geral.

Fechando o raciocínio desta descrição histórico-evolutiva, a autora define a hipermídia como um sistema alinear, reticular de conexões (links), resultante da hibridização do hipertexto com a multimídia. Este foi um processo de digitalização dos textos escritos, migrando-os para a tela dos monitores. Com este novo suporte a natureza se altera para o hipertexto, com vínculos não-lineares, realizando conexões conceituais (campo) e gerando metáforas visuais (ícones).

As conexões não são fixas, mas abertas às marcas pessoais de estilo de interação que o navegador impõe a elas. As unidades de informação podem aparecer sob a forma de textos, de imagens de qualquer espécie, fotos, desenhos, gráficos, vídeos e sons, também de várias espécies que vão da música ao ruído (SANTAELLA, 2011, p.295).

Esta dinâmica é formada por uma semiose específica resultante das diversas mídias que a constitui, portanto, a subjetividade do autor/leitor precisa ser analisada também sob esta ótica.

Para nos aproximarmos de uma leitura semiótica do hipertexto virtual, se faz necessário tomar a Teoria Semiótica de Pierce $^{14}$ e a releitura que dela faz Santaella (2007a) tendo como objeto de análise os hipertextos no ciberespaço. Este percurso teórico faz todo sentido porque as diversas mídias presentes no hipertexto e na hipermídia, objeto e sujeito do nosso estudo, são écrans simbólicos que convivem na tela do computador a cada acesso e se abrem em novos atalhos para a

\footnotetext{
${ }^{14}$ CORREIA. Claudio Manoel de Carvalho Correia. Fundamentos da Semiótica Peircena. PUC-SP. Disponível em: http://www.filologia.org.br/ixfelin/trabalhos/pdf/38.pdf. Acessado em: 07 mar. 2016.
} 
navegação. A linguagem escrita é eivada de símbolos, a imagem produz e pode ser símbolo, ícone e metáfora. Todos esses textos em conjunto atuam de forma orquestrada para trazer o movimento da fala para o espaço virtualizado.

No livro Semiótica Aplicada (2007a), Santaella nos apresenta um breve resumo dos conceitos que são relevantes no pensamento de Peirce para que possam ser aplicados metodologicamente à análise de mensagens e situações comunicativas e virtuais (PIERCE, 1995).

Este arcabouço teórico se fundamenta na Fenomenologia que investiga os modos como apreendemos as coisas que se apresentam à nossa mente e como afirma a autora, uma quase ciência que dá as bases às três ciências normativas: a estética, a ética e a lógica.

O pensamento de Peirce, um dos principais nomes da filosofia americana, possuidor de uma obra de extrema originalidade e de volume notável contribuiu significativamente para a abertura de novos caminhos ao questionar filosófico. Estudioso disciplinado, estudou com muito cuidado tudo o que se julgava importante nos métodos de investigação, aponta para uma semiótica que trata do pensamento e sua evolução e sobre as condições gerais dos signos. A Semiótica peirceana apresenta três ramos de estudo: a gramática especulativa, a lógica crítica e a metodêutica ou retórica especulativa (SANTAELLA, 2007a).

Segundo Santaella (2007a), na mesma obra, a gramática especulativa estuda todos os signos e formas de pensamento que eles possibilitam. A lógica crítica por sua vez, trata dos diferentes tipos de signos e as inferências, raciocínios e argumentos que se estruturam mediante signos e a metodêutica por fim, estuda os princípios do método científico. Os três ramos estão em uma relação de imbricamento e precisam ser considerados como um conjunto para se proceder à análise de todos os tipos de linguagens, signos, sinais e códigos.

Pierce apresenta, segundo a autora (SANTAELLA, 2007a), uma natureza triádica para o signo:

- Em si mesmo - nas suas propriedades internas, naquilo que o faz significar;

- Na sua referência - naquilo que ele indica, se refere ou representa; e 
- Nos tipos de efeitos - naquilo que é produzido nos seus receptores, nos tipos de interpretação que potencialmente desperta nos seus usuários.

Com isso, a teoria semiótica nos permite, segundo a autora, penetrar no movimento interno das mensagens, no modo como elas são engendradas e recursos nelas utilizados. Além de permitir vislumbrar as marcas históricas produzidas pelo sujeito.

Esse, portanto, é um processo teórico-metodológico e analítico que pretende dar conta de questões relativas às diferentes naturezas que as mensagens podem ter: verbal, imagética, sonora e todas as possibilidades de mescla dessas naturezas (SANTAELLA, 2007a).

Em função de ser uma teoria abstrata do campo das linguagens, a semiótica precisa lançar mão de outros aportes teóricos quando envereda por análises mais refinadas, no caso das obras de arte, do cinema e da publicidade. Ela funciona como um mapa lógico que traça as linhas dos diferentes aspectos de uma análise e não se basta em si mesma. Portanto, para a análise de hipertextos necessita-se do entendimento teórico da multimodalidade e da hipertextualidade.

Para Peirce (1995) há três elementos formais e universais em todos os fenômenos que se apresentam à percepção. Santaella (2007a), para facilitar o entendimento da teoria generaliza esses elementos em: primeiridade, secundidade e terceiridade.

A primeiridade aparece em tudo que se relaciona ao acaso, possibilidade, liberdade e sentimento. A secundidade se relaciona às ideias de dependência, dualidade, conflito, surpresa e dúvida. A terceiridade tudo aquilo que diz respeito à generalidade, continuidade, crescimento e inteligência (SANTAELLA, 2007a)

O signo de acordo com Santaella (2007a), ao sintetizar o pensamento pierciano, é qualquer coisa de qualquer espécie que representa uma outra coisa chamada de objeto do signo e que produz um efeito interpretativo em uma mente real ou potencial - interpretante do signo.

Esta compreensão da lógica triádica do signo é o que vai dar sentido as três teorias da Semiótica de Peirce que ampliam o entendimento do signo, teorias, 
segundo a autora, denominadas: da significação, da objetivação e da interpretação (PIERCE, 1995).

Com isso, temos signos formados pelas linguagens, pelas ações e reações cotidianas e até mesmo uma emoção, um sentir, podem significar, objetivar e ser interpretado. Esta visão perceiana dá as bases para uma semiótica para além da palavra porque nos permite pensar também como signos. Podemos ver esta ideia claramente esboçada quando Santaella (2007a) afirma:

É por isso que qualquer coisa pode ser analisada semioticamente, desde um suspiro, uma música, um teorema, uma partitura, um livro, publicidades impressas ou televisivas, incluindo a percepção que temos delas, na sua natureza de signos e misturas entre eles (p.11).

Segundo a autora, há três propriedades formais que possibilitam às coisas funcionarem como signos: sua qualidade em si, sua existência e seu caráter de lei.

Temos um quali-signo quando a qualidade produz uma cadeia de associações e tem o poder de sugerir o pensado ou se transformar quase no referencial. Por sua vez o signo em si - sin-signo- é a sua existência singular, sua propriedade de existir enquanto tal. Em se tratando da propriedade da Lei, deve-se pensar no caráter operativo desta. O legi-signo, portanto, é o caso singular que se conforma à generalidade da lei. A partir dessa conceituação triádica, Santaella (2007a) nos aponta de maneira sintética que se a relação que o signo tem com seu objeto se fundamentar em um quali-signo este signo passa a ser um ícone, se a relação for com seu referencial passará o signo a ser um índice e se a relação for mais profunda ainda e legislar generalizando, será um símbolo.

Estas informações ajudam a entender o círculo da interpretação de um signo, esta operação, segundo Santaella (2007a), realiza uma verdadeira radiografia ou microscopia de como acontecem os processos interpretativos. $O$ efeito que 0 signo provoca em uma mente real chama-se interpretante. Pierce, segundo a autora, apresenta três tipos básicos de interpretante, isto é, três passos para que o percurso da interpretação se realize.

O interpretante é algo mais amplo, aquém e além do intérprete. Há níveis diferentes de interpretantes. O interpretante imediato é o potencial interpretativo do signo, nível anterior ao encontro com o intérprete. O segundo nível é o interpretante 
dinâmico, isto é, o efeito que o signo produz em um intérprete. Nesse nível se instala a dimensão psicológica, porque está se falando de uma relação. Relação esta de caráter emocional, energético e lógico (SANTAELLA, 2007a).

Os ícones, segundo a semiótica peirceana, tendem a produzir este interpretante com mais intensidade. É o caso das músicas, poemas e certos filmes. Esta produção, entretanto, está presente em qualquer interpretação, mesmo que não se perceba (SANTAELLA, 2007a).

Os índices por sua vez, produzem o tipo de interpretante energético porque chamam nossa atenção, dirigem nosso foco mental. Por fim, o símbolo por produzir associações, carrega em si o potencial lógico do signo, pelos efeitos que produz na mente do intérprete.

Segundo Santaella (2007a), apenas o símbolo é triádico genuinamente: "A lei que lhe dá fundamento tem de estar internalizada na mente de quem o interpreta, sem o que o símbolo não pode significar. O hino nacional só simboliza o Brasil para quem internalizou essa convenção" (p. 27).

Há um percurso a ser seguido para a aplicação da semiótica peirceana. Esse percurso passa pelo contemplar para em seguida, discriminar e por fim generalizar. Todos esses momentos em consonância com a primeiridade, a secundidade e a terceiridade já descrita na obra.

Para Peirce, segundo a autora, esse é um exercício fenomenológico porque exige abertura espiritual para os fenômenos, deixando de lado a postura automatizada da nossa percepção. Abrir-se ao contemplar é abrir mão do julgamento e deixar acontecer a escuta sensível:

\footnotetext{
Algo similar a esse estado que temos de aprender a desenvolver quando nos colocamos diante de processos de signos que pretendemos ler semioticamente. Em um primeiro momento, pelo menos, temos de dar aos signos, o tempo que eles precisam para se mostrarem. Sem isso, estamos destinados a perder a sensibilidade para seus aspectos qualitativos, para seu caráter de quali-signo (SANTAELLA, 2007a, p.30).
}

O olhar da observação é a abertura para a percepção que nos alerta para a existência singular do fenômeno e saber distinguir os limites do contexto que o diferenciam. Com este olhar se desenvolve considerações situacionais sobre o 
universo no qual o signo se manifesta e do qual é parte. Portanto, estamos diante do sin-signo.

Por fim, teremos o olhar generalizador que procura abstrair o geral do particular. Para isso, deve-se ter em conta as singularidades, as leis e os aspectos mais abstratos do fenômeno.

Para Santaella (2007a), os quali-sin-legi-signos são aspectos inseparáveis que as coisas exibem e que permitem que os signos existam. Para Pierce o mundo apresenta coisas ou fenômenos que significam, ele não separa o signo da sua materialidade, e como ele se apresenta à nossa mente.

\begin{abstract}
Assim, as palavras que você lê agora tem o seu corpo físico no papel impresso deste livro. Imagens têm seu corpo físico em películas, papeis, telas eletrônicas etc. Sons tem seu corpo físico na vibração do ar, e assim por diante. Mesmo o pensamento mais abstrato tem uma materialidade própria na neuroanatomia do cérebro. (SANTAELLA, 2007a, p.33)
\end{abstract}

Outro ponto central na análise semiótica proposta por Santaella é ter claro a diferença entre objeto dinâmico e objeto imediato do signo. O primeiro desses objetos se refere ao como o signo se reporta àquilo que ele quer ou pode representar. Este objeto determina o signo. Mas o acesso a esta representação só ocorre se conhecermos o objeto imediato a que ele se refere internamente.

Quando o signo é interpretado está aí embutido o fundamento e sua relação com o objeto. Para esta interpretação no cotidiano usa-se a intuição, mas quando se faz sua análise, realiza-se um movimento de explicitar as relações que os signos travam com seus objetos e todos os níveis interpretativos.

Uma semiose, segundo Santaella (2007a), só pode ser estudada a partir do ponto de vista do analista. Quando a interpretação analítica se dá, ela ocorre com o suporte de ferramentas conceituais que examinam como e porque a sugestão, a referência e a significação são produzidas.

O emprego dessas ferramentas conceituais com o suporte da pesquisa de campo que avalie os efeitos de um dado processo de signos, em um determinado universo de pessoas, é o contraponto às análises individuais e singulares. 


\subsubsection{A hipermídia - novos territórios}

Tomamos como aporte teórico complementar aos estudos de Santaella, a discussão realizada por Sérgio Bairon, pesquisador do grupo da teórica, com o livro O que hipermídia, publicado em 2012. Para o autor, a hipermídia é a linguagem nãolinear que atua de forma multimidiática e tem sua origem conceitual no jogo: "No aspecto filosófico, a linguagem hipermídia, quando compreendida como um jogo, assume o princípio de que linguagem e ser são sinônimos, o que proporcional a afirmar que jogar é ser jogado" (BAIRON, 2012, p. 8).

Como hipertexto e hipermídia enquanto recurso tecnológico são assuntos que apresentam praticamente a mesma trajetória histórica, vamos dar relevância ao termo hipermídia como uma expressividade da linguagem e não o resultado de uma evolução tecnológica, porque para Bairon (2012), o caminho para nos acercarmos desse conceito é conjugar princípios teóricos para que se continue acompanhando os caminhos da comunicação digital hipermídia.

O texto hipermidiático permite ao leitor um mergulho como se adentrasse uma paisagem. Esta imersão pode acolher, segundo o autor, os desvios da nossa polifonia:

\footnotetext{
As margens digitais fazem do movimento sua ludicidade existencial e o do ícone simplesmente ícone, sem precisar descrevê-lo com significantes; ou seja, aproximam uma compreensão emocional do universo lógico. Podemos imergir, e os objetos podem emergir, graças à proximidade entre imagem $\mathrm{e}$ conceito (BAIRON, 2012, p.13).
}

$\mathrm{Na}$ leitura da letra transformamos em som toda palavra lida, na leitura digital podemos transformar em leitura o som, em imagem a leitura, em movimento a imagem, em arte a forma de pensar tradicional e vice-versa. Com isto o leitor realiza múltiplas e superlativas leituras, multiplicam os sentidos e a quantidade de informações. Este crescimento demanda também um maior número de filtros para que a comunicação aconteça.

O autor vai trazer Barthes para a conversa por diversas vezes ao longo da obra. Bairon (2012) afirma que o ideal reticular pensado por ele que afirmava ser o texto, abundantes redes atuando entre si, sem superposição ou imposição já 
sinalizava para a galáxia de significantes, de códigos com diversas vias de acesso e infinitas possibilidades de significação que a linguagem hipermidiática proporciona.

Outro aspecto importante tratado por Bairon (2012) é o enfraquecimento de um eu que tudo pode conhecer e possui todas as referências textuais, ideal tão marcante na cultura intelectual de hoje. Se tomarmos a obra de Barthes denominada O grau zero da escrita, veremos que este autor já costura uma crítica à psicologia do eu, e aponta para um eu dinâmico e construído por diversos fragmentos e no mesmo caminho está Bakthin quando discute a polifonia. Assim, se formos pensar na hipermídia como criação e autoria, veremos como se torna complexa a relação texto/autor/leitor que se mantém em constante construção.

Para Bairon (2012), hipertexto e hipermídia hoje se confundem diante da soma e de relacionar várias mídias possibilitando que as referências individuais brotem do cotidiano.

O nosso cotidiano está profundamente relacionado com a 'metodologia da
decomposição' na qual filosofia e linguagem ordinária podem se encontrar.
[...] Também na hipermídia podemos penetrar, [...] no mundo da polifonia
multimidiática, pois do cursor ao movimento da imagem, o sujeito, agora
mais subjetivo que simbólico pode fazer parte atuante do cenário (BAIRON,
2012, p.19).

Com esta afirmativa fica claro que o autor vê a hipermídia como um jogo polifônico, como um jogo de construção de mundo, porque possibilita abrir um universo de interpretação de infinitas elaborações semânticas. Jogo e linguagem estariam atuando de modo cooperativo em primeira instância e em segundo instância sendo a mesma estrutura que organiza o horizonte humano. As partidas se sucedem porque não há a última palavra, há uma circularidade da compreensão. Aqui o autor se aproxima do círculo bakthiniano, à abertura da obra, a dialogicidade que se baseia na enunciação, a um estar no mundo dialógico, da circularidade cultural:

Assim o todo nunca pode acabar-se e separar-se. Quando se realiza um todo, é em virtude de uma definição já aberta à mudança. É nesse contexto de valorização da circularidade da compreensão que Bakthin tem sido muito requisitado como parte de uma bibliografia teórica sobre linguagem e hipermídia (BAIRON, 2012, p.26).

São estes recursos hipermidiáticos que têm sido vistos e utilizados hoje pelo movimento de mulheres, como um espaço/tempo para se pronunciarem, 
aproximando-se da oralidade tão cara à formação nas rodas e círculos de conversa dos grupos organizados de mulheres dos mais diversos segmentos no Brasil e no exterior.

Vejam apenas um exemplo disso ${ }^{15}$ :

Desde junho, quando as mobilizações sociais populares atingiram um novo patamar nas ruas e nas conquistas, a CAMTRA - Casa da Mulher Trabalhadora vem se esforçando para marcar uma perspectiva feminista nesse contexto.

Estamos participando das manifestações, articulações de mulheres para as mobilizações, estimulando a visibilidade das pautas feministas nos movimentos durante os diversos momentos: transportes e serviços públicos, - Estado Laico, repressão policial, contra as políticas de segurança e mercantilização da cidade, educação, entre outras. $O$ feminismo historicamente apresenta reivindicações, a partir da perspectiva das mulheres, em relação a todas essas pautas. Queremos discutir as demandas e participações das mulheres: o que nós levamos para as manifestações, não só enquanto feministas, mas o que as mulheres levaram e vivenciaram - a violência da polícia e a ameaça de grupos misóginos, o machismo se mostrando nas manifestações, ocupações e movimentos, inclusive de esquerda, a invisibilidade das demandas das mulheres, entre outros. O que o feminismo tem a ver com isso e o que a CAMTRA, enquanto organização feminista que estimula a organização das mulheres e defende os seus direitos, propõe nessa conjuntura? Diante disso, quais são os nossos desafios?

Por isso, chamamos para a Roda de Conversa da CAMTRA: "O Olhar das Mulheres sobre as Mobilizações" para colocarmos tudo isso e mais!

ATIVIDADE AUTO-ORGANIZADA DE MULHERES!

Participe: https://www.facebook.com/events/681327688544968/?ref dashb oard filter=calendar.

Estes grupos estão reunidos em comunidades, sites, blog e outros dispositivos que formam o ciberespaço.

\subsubsection{Blogosfera como círculo de cultura - uma leitura do pronunciamento feminino na perspectiva freireana}

Todos nós educadores nos formamos mediante as bases epistemológicas que nos foram apresentadas ao longo da nossa preparação para a docência. Entretanto, parece que o contato com a Pedagogia de Paulo Freire não acontece como com outros teóricos. Nasce em nós um sentido de pertencimento a um Círculo.

\footnotetext{
${ }^{15}$ Artigo: Roda de Conversa da CAMTRA: O olhar das Mulheres sobre as Mobilizações. Disponível em: http://www.camtra.org.br/noticias/78-roda-de-conversa-da-camtra-o-olhar-das-mulheres-sobre-asmobilizacoes. Acesso em: 18 out. 2014.
} 
Um grupo de educadores das mais diversas origens que são tomados por uma paixão: a paixão de educar.

Tive o privilégio de conhecer Paulo Freire quando representante discente nos colegiados da Universidade de Brasília (UnB) e militante estudantil, nos idos de 1980. Um ser humano e educador raro, que sentava conosco e debatia com doçura as ideias mais radicais e revolucionárias. Nunca me esqueci dos seus pés, sob as grandes mesas de reunião na Reitoria da Universidade, quando os balançava, tranquilamente, no meio das discussões mais acirradas.

Tive contato com seu pensamento pedagógico das mais diversas formas, tanto como aluna de graduação, como docente do ensino superior, como pesquisadora, como militante da educação e como militante feminista. E posso assegurar que seus textos nos impulsionam para uma ação educativa transformadora, nos impulsiona para olhar o mundo de outra forma, nos provoca até que a nossa palavra se faça verbo e se pronuncie nos espaços macro e micro políticos.

Paulo Freire, segundo Cardarello (2005), foi herdeiro dos teóricos que escolheu, que o tocaram, que considerava potentes e o potencializava. Ele fez aliança com a Fenomenologia, com o Humanismo, com a Teologia da Libertação, com o Marxismo, com a Dialética Hegeliana e com o Existencialismo. Freire reinventou estas heranças, criando uma pedagogia do oprimido, uma concepção de educação problematizadora, método ou epistemologia de letrar adultos. Com isso, segundo a autora, ele alterou sentidos e os ressignificou. E para fortalecer esta potência teórica, ele também se cercou de outros autores, com os quais produziu diversos textos em parceria ou em diálogo com eles. Há sem dúvida, um Círculo Freireano que já ultrapassou as fronteiras brasileiras.

Tanto para Cardarello (2005) como para mim, Freire nos ensinou a deixar a pedagogia libertadora em movimento. Para sermos de fato herdeiras desta pedagogia, teremos sempre que ousar, colocando sentidos e sentires em movimento. Tomá-los pelas mãos e traçar novos territórios, como preconiza Guattari (1993; 2013). Vermos o já visto, como se visse pela primeira vez, contemplar o mundo em um cíclico movimento de vida e morte. 
Trazer Freire para pensar a produção autoral de um blog feminino e feminista, é concordar com Giles Deleuze quando afirma que "[...] pensar é experimentar, é problematizar [...], é emitir singularidades, é lançar os dados" (DELEUZE, 1988; p. 125).

Os dados foram lançados no tabuleiro, porque antes de qualquer coisa, estamos debruçados sobre um hipertexto eletrônico, uma das formas de linguagem líquida, como bem nomeia Santaella (2007), produzido por um sujeito que está no mundo e se subjetiva na relação consigo mesmo e com os outros. Sujeito que ousa ser livre para contar de si. Temos, portanto, a tríade da pedagogia freireana, apontada por Cardarello (2005): o sujeito, o mundo e a liberdade.

Durante o meu mestrado aprofundei meus estudos da obra freireana e pensei que ele estaria comigo em todos os momentos da minha prática pedagógica definitivamente. Mas ele foi mais além, retornou de modo amoroso durante a construção do referencial teórico desta tese. Eu fui sendo envolvida em círculos de autores, que se identificavam como autores que pensavam juntos e escreviam juntos, a dialogia perpassando tudo. Como educadora feminista e como esotérica sou influenciada pelas danças circulares sagradas, pelas rodas de leitura com as crianças, com os contadores de história, com as mandalas que resumem o mundo, com o próprio movimento circular da vida do pensamento oriental.

Com Freire aprendi que o subalterno, o oprimido e o excluído têm direito a voz e à sua história que se constrói na e pela palavra, não uma palavra qualquer, mas uma palavra pronunciada, refletida e discursiva. E foi com esta certeza que deixei de ser professora para ampliar meus horizontes e estar no mundo como educadora. Porque o sou em todos os lugares e em todos os momentos. Sou a minha práxis.

Com esse olhar assim constituído e impregnado só pude ver a blogosfera como um grande círculo humano, constituído por outros círculos concêntricos que se comunicam e se misturam em ondas e dobras e se espraiam como rizomas e ganham cada vez mais espaço.

Se os blogs autorais fomentam o diálogo e a reflexão coletiva entre os sujeitos leitores, isto favorece a externalização do conhecimento tácito em conhecimento explícito. Aqui podemos aproximar Freire de Bakthin, porque ambos 
propõem que na comunicação dialógica é que a linguagem se concretiza, torna-se extralinguística, ganha as ruas e o nosso cotidiano. Assim ele completa esta ideia:

A ideia não vive na consciência individual de um homem isolado: mantendose apenas nessa consciência, ela degenera e morre. Somente quando contrai relações dialógicas essenciais com as ideias dos outros é que a ideia começa a ter vida, isto é, formar-se, desenvolver-se, a encontrar e renovar sua expressão verbal, a gerar novas ideias. O pensamento humano só se torna autêntico, isto é, ideia, sob as condições de um contato vivo com o pensamento dos outros, materializando na voz dos outros, ou seja, na consciência dos outros expressa na palavra. É no ponto desse contato, entre vozes - consciência que nasce e vive a ideia (BAKTHIN, 2002, p.86).

Assim, a dinâmica em rede da Blogosfera tenta de alguma forma lutar contra a ausência de um projeto coletivo de sociedade, educação, cultura, desejos e utopias que silencia o que há de autoral em cada ser humano, nos espaços formais e não-formais onde a troca de experiências e vivências tem um caráter de educação para a liberdade, como tanto discutiu Paulo Freire.

Quando nos acercamos mais intimamente da obra freireana, começamos a refletir sobre nós mesmos e o nosso porquê no mundo. Esta reflexão está bem concreta na obra Educação como prática da Liberdade, na qual mergulhamos no sentido de o verbo existir, que para o autor é muito mais que uma discussão espacial:

\begin{abstract}
Existir ultrapassa viver porque é mais do que estar no mundo. É estar nele e com ele. E é essa capacidade ou possibilidade de ligação comunicativa do existente com o mundo objetivo, contida na própria etimologia da palavra que incorpora ao existir o sentido de criticidade que não há no simples viver. Transcender, discernir, dialogar são exclusividades do existir. O existir é individual, contudo, só se realiza em relação com outros existires. Em comunicação com eles (FREIRE, 2003, p. 48).
\end{abstract}

As teorias nos possibilitam a expansão do olhar, da busca e para construirmos esta reflexão sobre a Blogosfera como Círculo de cultura na sua fundamentação existencial, tomamos como referência quatro obras fundamentais de pensamento freireano: Pedagogia do Oprimido, Educação como prática da Liberdade, Pedagogia da Esperança da Autonomia. Esta escolha não nos impede, contudo, de pinçarmos reflexões de outras obras do autor para desenhar melhor a discussão apresentada neste trabalho.

Em Pedagogia do Oprimido, o autor afirma que "[...] existir humanamente, é pronunciar (grifo nosso) o mundo, é modificá-lo" (FREIRE, 1987, p.78). E neste 
movimento também se construir como sujeito e autor da própria história. Portanto, mergulhemos no entendimento do Círculo de Cultura freireano para termos a clareza da força de vida presente na Blogosfera que favorece o pronunciamento das mulheres, como cidadãs de direitos, produtoras de cultura e transformadoras do mundo.

\subsubsection{O Círculo de cultura - na perspectiva de educação para a liberdade}

Quando falamos de Círculos de Cultura, estamos logo de início pensando na realização do encontro entre pessoas ou grupos de pessoas que desenvolvem um trabalho didático-pedagógico ou a outras vivências culturais e educacionais, visando a um processo de ensino e de aprendizagem, qualquer que seja o espaço onde isso aconteça.

Isso significa que esta reflexão serve não só para a educação formal, que acontece dentro de uma escola regular, mas também para qualquer iniciativa educacional, dentro da sala de aula ou em outros espaços onde acontece o encontro entre pessoas que aprendem e que, ao fazê-lo, ensinam algo umas às outras. Um círculo no qual todas as pessoas participantes de um processo de troca de vivências podem pesquisar pensar, praticar, refletir, sentir, deliberar, ser, plantar, agir, cultivar, intervir e avaliar o seu fazer, em um movimento permanentemente dialógico. Processo de cara importância para este estudo, uma vez que o processo dialógico é para nós a via de construção do sujeito, ou seja, que ele possa dizer "sua palavra", seu ser e estar no mundo.

O conceito de dialogicidade em Freire $(1987 ; 2003)$ é a sustentação de sua visão antropológica, que produziu um pensamento eminentemente humanista e libertador. Esta é uma prática de diálogo verdadeiro, aquele que mantem viva a relação entre a ação e a reflexão. Esta prática, também de caráter dialético, é uma condição existencial do humano e, portanto, histórica, incompleta e prenhe de humanização.

Dito isto, temos claro que a base que fundamenta o Círculo de Cultura, é o diálogo. É na palavra pronunciada, que revela o mundo, que a autora e leitores do blog Sapatilhando, se fazem, ao fazer e refazer o próprio mundo quando há uma 
escrita de si, hipertextual, hipermidiática que se aproxima da oralidade, direcionada ao outro que lê e também se diz. Daí, com base em Freire e Bakhtin, vemos a presença da ação educativa.

Para este educador pernambucano, a educação é um processo de libertação. Há para ele uma dimensão política do ato pedagógico e educativo. Esta certeza é fruto da sua trajetória como educador e das escolhas que fez ao longo da vida e se percebe como ser inacabado, que construiu se próprio caminho, tecendo o hoje no ontem e o nosso futuro quando herdamos a sua fé no homem, como ser de práxis.

Nas suas obras, Freire dialoga com seus leitores e traça elos entre 0 ontem e o que está escrevendo, portanto, em mudança e reflexão. Em Pedagogia do Oprimido (1987), ele retoma a discussão da obra anterior, Educação como prática da liberdade (2003) e insere uma re-leitura do processo dialógico e leva em conta a luta das mulheres como cidadãs de direitos para a evolução do ser humano.

Desta maneira, nada mais coerente do que inserir a discussão do pronunciamento feminino como forma de pensar criticamente a estrutura social para que se possa expor a forma pela qual se constitui a sociedade e o próprio homem. Respondendo a uma interrogação que me acompanha desde os primeiros escritos deste trabalho, interrogação que li em uma grande obra sobre estudos culturais, publicada em um pequeno livro de uma indiana ${ }^{16}$ que interpelava: Pode o subalterno falar? (SPIVAK, 2010). E está interrogação ficou gravada em mim e me acompanha a cada linha desse trabalho e da minha militância como educadora e feminista. A autora defende que o silêncio da mulher na sociedade que vivemos é uma forma de resistência diante do status quo. Isto pode ser fato entre as mulheres das classes populares, mas já existem movimentos de mudança, como a formação de promotoras legais populares no Brasil, com 0 intuito de instrumentalizar juridicamente as mulheres para a defesa dos seus direitos. Para isso, agem em rede

\footnotetext{
${ }^{16}$ O sujeito subalterno na definição de Spivak (2010) é aquele pertencente "[...] às camadas mais baixas da sociedade constituídas pelos modos específicos de exclusão dos mercados, da representação política e legal,e da possibilidade de se tornarem membros plenos no estrato social dominante"(p.12). Avançando no tema, e tendo como ponto nodal a história de uma viúva, duplamente impedida de se auto-representar, primeiro por ser mulher e segundo por sua condição de viuvez, a autora sustenta que esta situação de marginalidade do subalterno é mais arduamente imposta ao gênero feminino, posto que a "[...] mulher como subalterna, não pode falar e quando tenta fazê-lo não encontra os meios para se fazer ouvir" (SPIVAK, 2010, p.15) (grifo nosso). Trecho da resenha disponível em: http://www.uft.edu.br/pgletras/revista/resenhas/resenha n.4.pdf.
} 
diversos movimentos de mulheres intelectuais para propiciar esse diálogo (SPIVAK, 2010).

Quando das ações de luta pela garantia dos direitos das mulheres no Brasil, o movimento feminista ganha as avenidas e em seu seio, marcham juntas mulheres de todas as camadas sociais, porque todas sabem que "juntas somos mais fortes", como afirma a palavra de ordem puxada pelo movimento de combate à violência contra a mulher, concretizado nas diversas Marchas das vadias que eclodiram nos últimos anos nas diversas capitais brasileiras e se espalharam como febre nas redes sociais e com isso, surgiu o fenômeno da blogagem coletiva disparada simultaneamente na Blogosfera, pela iniciativa das Blogueiras Feministas.

O Círculo de Cultura a que se refere Freire em sua obra foi uma ação concreta de alfabetização política na luta do homem para que desenvolvesse sua dialogicidade que ocorreu nos idos dos anos 60. Desta ação, fica para nós fortemente a ideia de que no círculo todos os seus participantes podem se olhar, não há a materialidade de mesas ou filas, como nas salas de aula. Como também os momentos fundamentais desta ação, quais sejam: a investigação, a tematização e a proposição diante de um processo educativo que abre a perspectiva de um fazer cultural.

E a dimensão da Cultura apreendida por nós neste trabalho, é a de que Cultura se caracteriza e se produz nas interações do homem com a realidade, recriando-a e buscando-se o movimento e seu espaço no mundo. Freire afirma e nos confirma que o homem quando no Círculo, "[...] vai dominando a realidade. Vai humanizando-a. Vai acrescentando a ela, algo que ele mesmo é fazedor. Vai temporalizando os espaços geográficos. Faz cultura" (FREIRE, 2003, p. 51).

No blog Sapatilhando se realiza este movimento quando a autora traz para suas postagens depoimentos sobre sua vivência cotidiana e compartilha com a Blogosfera. Na troca entre autora/leitores, vemos o face a face da escrita de si. E nos depoimentos das leitoras, o movimento de domínio da sua subjetividade quando no processo de identificação com a autora se dizem novamente ou compartilham a emoção de estar se vendo como se fosse a primeira vez refletida no olhar da outra que escreveu se autorizando. 
Além disso, há também a possibilidade de todos lerem todos, a escrita da autora e os comentários dos diversos leitores, de modo a todos refletirem juntos, de modo crítico, sobre a figura que os mediatiza. Com isso, cada um se descodifica, passando do abstrato para o concreto, da parte ao todo, para depois voltarem e refletirem sobre si mesmos. Isto implica que autora e leitores se reconheçam em uma situação em que não estão sós, mas se encontram com outras pessoas:

Se a descodificação for bem feita, este movimento de fluxo e refluxo, do abstrato ao concreto, que se produz na análise de uma situação codificada, conduz a substituir a abstração pela percepção crítica do concreto, que deixou já de ser uma realidade densa e impenetrável. [...] e passa a ser um desafio a que os homens (mulheres) devem responder (FREIRE, 1984, p.70).

Com este trecho do autor, procuramos descrever como funciona o trabalho de codificação e decodificação que estrutura o Círculo de Cultura quando da alfabetização de adultos, de caráter não apenas de conhecer as letras e o alfabeto, mas um trabalho de letramento e politização. Essas duas faces do trabalho de Freire na verdade buscam legitimar o elemento central do círculo, que é o tema gerador.

O tema gerador é a temática significativa para a compreensão crítica da realidade. No blog Sapatilhando, a discussão da Lesbianidade se apresenta muito mais que uma questão de gênero, porque a sua autora ou coordenadora do Círculo, com o tema discute o ser e estar no mundo, como agir dada a consciência da sua identidade, como também se posiciona diante da sociedade, da família e fundamentalmente diante de si mesma. Uma busca de significação existencial e nesse pronunciar-se está na parceria com os leitores que acessam o blog e mediante a oferta constante de canais de diálogo com a autora, há garantia da dialogicidade para que todos possam trocar vivências e experiências, como forma de criar laços de comunidade.

Entretanto, não basta estar em círculo ou debater sobre um tema para ser uma atividade praxística, faz-se necessário que os sujeitos envolvidos nesse processo tragam saberes ou convicções intersubjetivamente partilhadas nas ações circulares, optando pela capacidade coletiva de agir sem coações e de produzir consensos, em que todos desenvolvam sua vida, sua leitura e construção de mundo. Desta forma, em ações coletivas, o ser humano busca seu acabamento. É na 
dialogicidade que ele se lança ao devir, cria novos territórios, a fim de se abrir para novas cartografias, enquanto sujeito que move o mundo e se move com ele.

Assim, está a poiesis da Blogosfera quando o feminino se abre, se configura, se expõe e permite que estas ações sejam processuais e educativas, enxergando o que é individual na diversidade protagonista e autoral do ser enquanto sujeito humano coletivo, dialógico e simbólico por natureza; autorizar-se. Autorizando.

\subsubsection{O pronunciamento, na perspectiva freireana}

Na obra intitulada Dicionário Paulo Freire (STRECK; REDIN; ZITKOSKI, 2010), acercamo-nos daquilo que o autor entende por pronunciamento e para começo de conversa refletimos sobre a citação de abertura dos autores do livro:

Paulo Freire foi um semeador e cultivador de palavras. Não de quaisquer
palavras, mas de palavras "grávidas de mundo", como dizia. Palavras que
têm o dom de gerar mundos, de pronunciar novas realidades. A
intencionalidade que orientou a organização deste Dicionário Paulo
Freire foi a de apreender sua trajetória humanizadora. Ninguém terá
pretendido dizer a palavra derradeira sobre nada. No sentido de Freire,
como reafirmado várias vezes ao longo deste Dicionário, buscou-se, isso
sim, fazer um exercício do pensar certo na perspectiva de uma reflexão
rigorosa e metódica. (STRECK; REDIN; ZITKOSKI, 2010, p. 13).

Para Paulo Freire, do ponto de vista da formação, a existência humana não pode ser silenciosa, deve nutrir-se de palavras verdadeiras. Palavras estas que produzam diálogo e libertação. "O mundo pronunciado, por sua vez, se volta problematizado aos sujeitos pronunciantes, a exigir deles novo pronunciar" (FREIRE, 1987, p.78).

Com esta afirmação, nosso autor traz para a luz a práxis que seria o trabalho do homem para transformar o mundo, como um direito de todos e não de alguns. Esta palavra verdadeira, a práxis não se pronuncia sozinho, ela é dita no encontro entre os homens para dizer o mundo, portanto, atingindo a tudo que nos cerca.

O diálogo, para Freire (1987), é uma exigência existencial, um ato de criação que não pode ser manipulado por alguns em detrimento dos outros. E nesse ato se faz necessário um profundo amor aos homens e ao mundo. 
Em Pedagogia do Oprimido (1987), nosso autor, finca as bases filosóficas da educação dialógica. A educação que se baseia na palavra e no amor. Um amor que se caracteriza por ser um ato de coragem, de compromisso com os oprimidos, não importa onde eles estejam, e ter com eles também amor pela sua causa.

Além disso, é preciso ter fé nos homens, sendo este um dado a priori do diálogo. "O homem dialógico tem fé nos homens antes de encontrar-se frente a frente com eles. [...] A confiança vai fazendo os sujeitos dialógicos cada vez mais companheiros na pronúncia do mundo" (FREIRE, 1987, p. 113).

A pronúncia do mundo se dá quando ao refletir sobre sua realidade, tendo como ponto de decisão a busca de si, o ser humano impregna o mundo com sua presença criadora e através das mudanças que opera e com isso transformam sua existência em existência histórica.

Esta existência histórica, se olharmos a luta das mulheres pelo reconhecimento dos seus direitos e cidadania, exigiu delas e dos movimentos sociais por elas criados, atos-limite:

Desta forma, o próprio dos homens é estar, como consciência de si e do mundo, em relação de enfrentamento com sua realidade em que, historicamente, se dão as situações-limite. E este enfrentamento com a realidade para a superação dos obstáculos só pode ser feito historicamente, como historicamente se objetivam as situações-limite (FREIRE, 1987, p. 126).

Os atos limites necessários para superar as situações-limite é um trabalho pedagógico a partir da consciência do inacabamento humano, um atuar na busca da construção da autonomia.

Se considerarmos a autonomia como processo pedagógico e a luta das mulheres como busca de autonomia e de pronunciamento, podemos apontar para alguns princípios que Freire (1996) toma como fundamentais para aquele que ensina que é o mesmo que aprende no processo de ação-reflexão-ação.

Se o blog que analisamos é o pronunciamento de uma mulher no seu processo de subjetivação que se dá em comunhão com outras mulheres, podemos arriscar dizer que ela se subjetiva, aprende e ensina nesse processo de busca de si. 
Portanto, esta escrita de si que milita no ciberespaço, apresenta algumas exigências para ser de fato portadora de emancipação e respeito às multiplicidades humanas.

Não há transferência de conhecimento no ensinar verdadeiro, o ensinar é uma troca na qual os aprendentes tem consciência de que são inacabados, reconhecem que são condicionados pelos agenciamentos sociais. Se faz necessário também tolerância e humildade e luta em defesa dos direitos dos educandos ou aprendentes, exige também alegria e esperança e a convicção de que a mudança é possível.

Ensinar para Freire (1996) também exige a compreensão de que a educação é uma forma de intervenção sobre o mundo, que exige liberdade e saber escutar e, sobretudo um querer bem aos educandos.

Este querer bem nasce da consciência de que se é gente que se abre para o outro, entendimento que muito cedo se deu em Freire (1996):

[...] desde jovem, sempre marchei da minha casa para o espaço pedagógico
onde encontro os alunos, com quem comparto a prática educativa. Foi
sempre como prática de gente que entendi o que fazer docente. De gente
inacabada, de gente curiosa, inteligente, de gente que pode saber, que
pode por isso ignorar, de gente que, não podendo passar sem ética se
tornou contraditoriamente capaz de transgredi-la (p.164).

Este processo de pronunciamento e autonomia da mulher pode ser visto nos últimos trinta anos no movimento feminista e de mulheres brasileiras que avançou por todo o território nacional. Segundo o documento base da $4^{\underline{a}}$ Conferência Nacional de Políticas para Mulheres, produzido em junho de 2015, este movimento se constitui em uma poderosa narrativa de desconstrução das desigualdades históricas estabelecidas entre mulheres e homens. Um movimento que denunciou a invisibilidade feminina nos espaços domésticos e sua posição secundária na sociedade. "E de vitórias e derrotas chegamos ao século XXI mais velhas, mais educadas, com maior visibilidade sócio-política, mas ainda desiguais" (BRASÍLIA, 2015, p. 7).

Apesar das diferentes pautas defendidas pelos movimentos de mulheres, o documento afirma que todas foram e são responsáveis por trazer aos espaços públicos as temáticas relacionadas aos problemas que enfrentam as mulheres. 
Nesse sentido, as mulheres têm feito um movimento de pronunciamento da palavra verdadeira baseada na prática do diálogo e numa ação praxística para colocarem-se no mundo, educando e sendo educadas pela e para a sociedade, fortalecendo os laços, tanto nos espaços públicos quanto no ciberespaço, também exercendo um ciberativismo.

Do ponto de vista freireano é preciso pensar sobre nós mesmos para que encontremos na natureza humana, o núcleo fundamental onde se sustente o processo educacional de cada um de nós, homens e mulheres. Para Freire (1979), na obra Educação e Mudança, esse núcleo seria o inacabamento ou a inconclusão do ser humano. "A busca deve ser algo e deve traduzir-se em ser mais: é uma busca permanente de si mesmo. [...] Esta busca deve ser feita com outros seres que também procuram ser mais e em comunhão com outras consciências" (p.28).

Desta feita, o movimento de mulheres, nas suas mais diversas formas de mobilização e instrumentos de militância e de auto-reflexão praticam cotidianamente os pares apontados pelo autor: saber-ignorância, amor-desamor, esperançadesesperança.

Esses pares são importantes porque a educação tem caráter permanente, estamos todos nos educando. Não há para Freire (1979) educação sem amor porque o amor é uma luta contra o egoísmo. "Quem não é capaz de amar os seres inacabados não pode educar" (p. 29).

Por fim, tendo como base o inacabamento humano, esperamos porque buscamos e não há busca sem esperança. O homem é um ser de relações que está no mundo e com o mundo:

Se apenas estivesse no mundo não haveria transcendência nem se objetivaria a si mesmo. Mas como pode objetivar-se, pode também distinguir entre um eu e um não-eu. Isto o torna um ser capaz de relacionar-se; de sair de si; de projetar-se nos outros; de transcender. Pode distinguir órbitas existenciais distintas de si mesmo (FREIRE, 1979, p.30). 


\section{CAPÍTULO 2.3 O CÍRCULO METODOLÓGICO - A CARTOGRAFIA POIÉTICA}

A escolha de um caminho metodológico se cerca de diversos momentos de observação e reflexão. Estar diante do humano, do fazer humano, do pensar humano é uma posição de luz diante de um prisma, tamanha é a dinamicidade e complexidade desse ser, estar e fazer.

Buscamos uma metodologia como se buscássemos a nós mesmos, um fazer que nos identifica e dá voz. Como se quiséssemos uma lente que de fato conseguisse olhar o que queremos estudar e dessa conta do tanto que há de nós neste objeto de pesquisa e de desejo. O desejo de saber nos toma quando debruçados e abraçados nos unimos a um universo ou recorte de pesquisa.

A complexidade é uma maneira de compreender a realidade em que aspectos como a desordem, a contradição, o pluralismo, a singularidade, a diversidade, a indivisibilidade e o histórico são princípios importantes.

Tomamos como premissa, que a construção de conhecimentos margeia os vários momentos de investigação que o pesquisador desenvolve, não acontece em um momento único desse processo, mas é uma ação constante frente à multiplicidade de materiais empíricos que podem ser coletados, se caracterizando pela atividade pensante e construtiva do pesquisador. Atividade que se inicia quando se toma consciência do prisma e suas possibilidades de luz que é o humano. Muitas vezes, diante desta constatação o pesquisador se vê na necessidade de acolher mais de uma trilha neste caminho metodológico por conta da multifacetada realidade.

Temos a compreensão de que a pesquisa é um processo de comunicação, um processo dialógico, pois a maioria dos problemas sociais e humanos se expressa na comunicação direta e indireta entre as pessoas.

A pesquisa desenvolvida neste trabalho busca desenhar uma cartografia, com suas bases fundadas no Método Cartográfico de Deleuze e Guattari (1996), que não utiliza modelos estruturais prontos com questões definitivas a serem respondidas e nem apresenta caminhos anteriormente traçados. Isto, contudo, não é 
a negação de uma diretriz de percurso, mas a afirmação dos processos e devires que estruturam o campo humano e social, cenário em movimento permanente oscilando e se misturando entre caos e cosmos. "A cartografia parte do reconhecimento de que, o tempo todo, estamos em processos, em obra" (BARROS; KASTRUP, 2009, p.73).

A cartografia deleuziana ao contrário da cartografia tradicional que traça mapas, relevo e distribuição populacional, trabalha em uma perspectiva social e até mesmo psicossocial:

O termo "cartografia" utiliza especificidades da geografia para criar relações de diferença entre "territórios" e dar conta de um "espaço". Assim, "Cartografia" é um termo que faz referência à ideia de "mapa", contrapondo à topologia quantitativa, que caracteriza o terreno de forma estática e extensa, uma outra de cunho dinâmico, que procura capturar intensidades, ou seja, disponível ao registro do acompanhamento das transformações decorrias no terreno percorrido e à implicação do sujeito percebedor no mundo cartografado (FONSECA; KIRST, 2003, p.92).

Deleuze dialogou com Foucault em suas formulações teóricas, há na perspectiva de análise cartográfica a influência da arqueologia do saber e do poder, discutidas por aquele autor. Em função disso, as metáforas espaciais e temporais se fazem presentes, mas enquanto movimento e processo.

Trabalha-se nesta perspectiva com uma estratégia de análise, que acompanha e descreve, buscando capturar intensidades, transformações ocorridas no espaço percorrido.

O diagrama não é mais o arquivo, auditivo ou visual, é o mapa, a cartografia, co-extensiva a todo o campo social. É uma máquina abstrata. Definindo-se por meio de funções e matérias informes, ele ignora toda distinção de forma entre um conteúdo e uma expressão, entre uma formação discursiva e uma formação não discursiva. É uma máquina quase muda e cega, embora seja ela que faça ver e falar. Se há muitas funções e mesmo matérias diagramáticas, é porque todo diagrama é uma multiplicidade espaço-temporal. Mas, também, porque há tantos diagramas quanto campos sociais na História (DELEUZE, 1988, p.44).

Tendo esta perspectiva processual, o método cartográfico é elaborado no e a partir do plano da experiência. Experiência que desenha e modifica ao mesmo tempo dos movimentos de transformação da realidade. Rolnik (1989) já afirmava que ao transportar a cartografia para as paisagens psicossociais, estaríamos com um instrumento de análise do nascimento e desmoronamento de mundos, de afetos que 
variam de intensidade e resvalam e são possíveis de serem captados pelo corpo, mediante sua capacidade de vibrar e ser afetado.

Paisagens psicossociais também são cartografáveis. A cartografia, nesse caso, acompanha e se faz ao mesmo tempo que o desmanchamento de certos mundos - sua perda de sentido - e a formação de outros: mundos que se criam para expressar afetos contemporâneos, em relação aos quais os universos vigentes tornaram-se obsoletos. Sendo tarefa do cartógrafo dar língua para afetos que pedem passagem, dele se espera basicamente que esteja mergulhado nas intensidades de seu tempo e que, atento às linguagens que encontra, devore as que lhe parecem elementos possíveis para a composição das cartografias que se fazem necessárias. O cartógrafo é antes de tudo um antropófago (ROLNIK, 1989, p.15-16).

A Cartografia é uma atividade que pode criar novos sentidos a partir dos sentidos dados e ressignificá-los, reconhece a indissociabilidade entre o psíquico e o social. Com isso, a prática do cartógrafo se aproxima da psicologia e da micropolítica, porque reconhece com seu trabalho a dimensão de análise da subjetividade.

A Cartografia é uma proposta de subversão, um exercício concreto de liberdade rompendo com o modelo do conhecimento da árvore, optando por uma orientação rizomática que se espraia em um campo ou fenômeno na busca do transbordamento e acompanhando os movimentos de busca de si.

Deleuze (1996) nesta construção trabalha com princípios do rizoma, quando destaca que qualquer ponto do rizoma pode estar conectado a qualquer outro, formando uma rede aberta e sem um centro determinado. Com este princípio trabalha com a ideia que o processo de busca de si não parte de um ponto, pode ter mais de um centro e se inicia em qualquer momento, dependendo da intensidade.

Desenvolve também a ideia da multiplicidade recusando as supostas unidades entre sujeito e objeto:

\footnotetext{
Inexistência, pois, de unidade que sirva de pivô no objeto ou que se divida no sujeito. Inexistência de unidade ainda que fosse para abortar no objeto e para 'voltar' no sujeito. Uma multiplicidade não tem nem sujeito nem objeto, mas somente determinações, grandezas, dimensões que não podem crescer sem que mude de natureza (as leis de combinação crescem então com a multiplicidade). (DELEUZE; GUATTARI, 1995, p. 16).
}

Rompendo com a ideia de que há um sujeito que observa uma dada realidade, o fenômeno observado envolve um campo. Este campo social ou psicossocial pode ser rompido ou quebrado em algum ponto e retomar em outro, 
gerando novos territórios e novas significações. Em função disso, o olhar do cartógrafo desenha um mapa ou diagrama variável. $\mathrm{Na}$ verdade, são mapas analíticos de um olhar que vibra.

É uma forma de pensar não dicotômica que busca a exterioridade das forças que atuam na realidade onde estamos mergulhados, buscando conexões para entender o que afeta a subjetividade. Então o olhar recai sobre as forças que atuam sobre cartógrafo e a realidade no qual ele está mergulhado.

Segundo dados da Capes do Ministério da Educação, nas Ciências Humanas, a Geografia e a Educação, congregam a maior parte (pouco mais de $70 \%$ ) dos Grupos de Pesquisa que lidam com cartografia.

Nas áreas das Ciências Humanas, de Ciências da Saúde e das Ciências Sociais Aplicadas a análise das informações dos Grupos de Pesquisa aponta que em muitos casos a cartografia a que se referem é aquela da proposição filosófica de Deleuze e Guattari, que conferem ao termo o significado de esquizoanálise, ou seja, análise das linhas de fuga que promovem desmanchamentos de territórios (ROLNIK, 1989).

\begin{abstract}
O termo "cartografia" utiliza especificidades da geografia para criar relações de diferença entre "territórios" e dar conta de um "espaço". Assim, "Cartografia" é um termo que faz referência à ideia de "mapa", contrapondo à topologia quantitativa, que caracteriza o terreno de forma estática e extensa, uma outra de cunho dinâmico, que procura capturar intensidades, ou seja, disponível ao registro do acompanhamento das transformações decorrias no terreno percorrido e à implicação do sujeito percebedor no mundo cartografado. (FONSECA; KIRST, 2003, p.92).
\end{abstract}

Segundo Prado Filho e Teti (2013), a cartografia social é a que trabalha campos de conhecimento das ciências sociais e humanas e, mais que mapeamento físico, trata de movimentos, relações, jogos de poder, enfrentamentos entre forças, lutas, jogos de verdade, enunciações, modos de objetivação, de subjetivação, de estetização de si mesmo, práticas de resistência e de liberdade.

No Brasil, a partir de 2005 a Cartografia passou a ser objeto de estudo por um grupo de pesquisadores que se debruçou sobre os escritos de Deleuze e Guattari para entender as bases que fundamentavam esta estratégia de pesquisa.

Este grupo produziu no coletivo o livro Pistas do Método da Cartografia: pesquisa-intervenção e produção de subjetividade, sob a coordenação de três 
professores pesquisadores, Passos, Kastrup e Escóssia (2009). A edição que utilizamos foi a de 2015. A obra traz uma coletânea de textos de diversos autores que tentam traçar um eixo para o melhor entendimento da Cartografia, porque Deleuze e Guattari vão desenvolver em duas obras as linhas gerais que apontam a Cartografia como estratégia: O Anti-Édipo (DELEUZE; GUATTARI, 2010) e Mil platôs (DELEUZE; GUATTARI, 1996), este último onde aprofunda a ideia de rizoma.

Em O Anti-Édipo surgiu a linha de pensamento idealizada por Gilles Deleuze e Félix Guattari, no qual três temas foram discutidos: o funcionamento do insconsciente como uma usina (produzindo sentidos) e não como um teatro, a discussão do delírio como algo histórico e mundial e os fluxos como o objeto da História (codificações e sobrecodificações). Esta obra é um marco porque foi uma forma de resposta às deficiências em premissas básicas da prática analítica. Guattari questionou a obra freudiana ao longo dos seus escritos, em especial o papel autoritário do psicanalista em relação ao paciente e também o uso do Complexo de Édipo como um marco inicial para a análise do sujeito:

Escrevemos o anti-Édipo a dois. Como cada um de nós era vários, já era muita gente. Utilizamos tudo o que nos aproximava, o mais próximo e o mais distante. [...] E finalmente, porque é agradável falar como todo mundo e dizer o sol nasce, quando todo mundo sabe que essa é apenas uma maneira de falar. Não chegar ao ponto em que não se diz mais EU, mas ao ponto em que já não tem qualquer importância dizer ou não dizer EU. Não somos mais nós mesmos. Cada um reconhecerá os seus. Fomos ajudados, aspirados, multiplicados (DELEUZE, GUATTARI, 2010, p.17).

Para o que nos interessa no entendimento da Cartografia, os autores apresentam a esquizoanálise e seus princípios como o trabalho que, a grosso modo, nos esclarece a conduta do pesquisador ou cartógrafo.

Em vez de se mover na direção de modificações reducionistas que
simplificam o complexo, a esquizoanálise vai trabalhar para a
complexificação, seu enriquecimento processual, para a coerência das suas
linhas virtuais de bifurcação e diferenciação, em suma para a sua
heterogeneidade ontológica (GUATTARI, 1992, p.14)

Portanto, ao se tratar de mapear a construção da subjetividade, devemos ter o entendimento de que:

1 - Não se impede o processo que se desenvolve. 
2 - Quando acontece alguma coisa, isso prova que acontece alguma coisa: o fato em si tem significado.

3 - A melhor posição para se ouvir o inconsciente não consiste necessariamente em ficar sentado atrás de um divã.

4 - O inconsciente compromete aqueles que dele se aproximam.

5 - As coisas importantes nunca acontecem onde nós as esperamos.

6 - Há transferências entre os sujeitos desejantes e maquínicos.

7 - Nunca nada é adquirido.

8 - Toda ideia de princípio, deve ser mantida, como suspeita.

$\mathrm{Na}$ busca das pistas para entender como a Cartografia se configura, os autores tomaram como fundamento esses princípios, já considerando que todo princípio deve sempre estar sob suspeita.

A Cartografia é vista por eles como uma estratégia de pesquisaintervenção por ser aquela em que a relação com o conhecimento leva à transformação do pesquisador. $O$ trabalho desse pesquisador, ou cartógrafo, por sua vez, se dá mediante gestos fundamentais quando ele rastreia o campo, toca-o para descobrir, metaforicamente pousa e faz um reconhecimento atento de tudo que se apresenta.

Cartografar é, portanto, acompanhar o processo, realizando movimentos e funções que partam de uma referência, de uma explicitação e que a produção da subjetividade também seja uma transformação da realidade.

Guattari em 1964, propõe o conceito de transversalidade para problematizar os limites do setting clínico, definindo esse conceito como um aumento dos quanta comunicacionais intra e intergrupos em uma instituição. Fazer análise é, cada vez mais, o trabalho de desestabilização do que se apresenta tendo a unidade de uma forma ou de um campo: o instituído, o indivíduo, o social. Do uno ao coletivo, esta é a direção da análise. Direção a quê? Não ao agrupamento, ao conjunto de indivíduos, nem à unidade do diverso, mas ao coletivo como dinâmica de contágio em um plano hiperconectivo ou de máxima comunicação (PASSOS ET AL, 2015, p.26)

Nessa observação deve-se considerar que há um plano coletivo onde os objetos e os sujeitos em seus contornos coexistem. Com isso, há a dissolução do ponto de vista do observador e o objetivismo e o subjetivismo passam a ser faces da 
mesma moeda. "O trabalho de pesquisa, assim como o trabalho de intervenção socioanalítica, pressupõe uma forma de relação entre os termos que aí interagem (sujeito-objeto, analista-cliente, teoria-prática)" (PASSOS et al, 2015, p. 28).

Cartografar, nesse sentido, é habitar um território existencial, imergindo no território e nos seus signos produzindo uma política da narratividade.

Segundo Passos et al (2015), a cartografia surge como um princípio do rizoma que atesta, no pensamento, sua força performática, sua pragmática. A realidade cartografada, segundo o autor, apresenta-se como mapa móvel, de tal maneira que tudo aquilo que tem aparência de "o mesmo" não passa de um concentrado de significação, de saber e de poder, que pode por vezes ter a pretensão de ser centro de organização do rizoma. Entretanto, o rizoma não tem centro.

Para Deleuze e Guattari (1996) somos compostos por segmentos que nos constituem, por linhas que se entrelaçam, compondo territórios. Algumas destas linhas, acreditam os autores, são impostas de fora para dentro, outras nascem do acaso e muitas vezes sem uma motivação específica, outras são inventadas, sem modelos prévios. Estas são as nossas linhas de fuga que só podemos traçá-las efetivamente na vida, na experiência de estar e ser no mundo.

Tomando de Deleuze as três linhas principais, que aos se entrelaçarem desenham nossos mapas territoriais que são inomináveis, organizam-se e crescem em redes e malhas existenciais.

$\mathrm{Na}$ cartografia desta tese consideramos como linha molar, aquela que representa os conjuntos sociais e institucionais e os relacionamentos entre as pessoas, o movimento de mulheres no seio da blogosfera se organizando como sujeito social. Assim, traçamos os contornos do Portal Blogueiras Feministas que se autodefine no seu perfil virtual como "Somos Mulheres e Homens. Somos de várias partes do país, com diferentes experiências de vida. Somos feministas". E no Editorial ${ }^{17}$ assim se apresentam:

Nosso objetivo é discutir feminismo. Em suas pluralidades e particularidades. Nas suas benesses e feridas. Além disso, queremos refletir sobre questões que cercam a formação de um mundo mais justo e igualitário para TODAS as pessoas.

\footnotetext{
${ }^{17}$ Portal Blogueiras Feministas. Editorial. Disponível em: http://blogueirasfeministas.com/about/nossamemorial. Acessado em: 22 de janeiro 2016.
} 
Este é um blog político, portanto, nos reservamos ao direito de não publicar textos que sejam contrários a nossos posicionamentos. Primamos pela crítica as estruturas e instituições, não a indivíduos.

Buscamos não difundir preconceitos e buscamos utilizar os princípios da interseccionalidade em nossos textos. Nem sempre somos bem sucedidas, por isso, para que o aprendizado seja conjunto e que a mudança seja uma possibilidade de construção coletiva, preferimos que críticas sejam feitas abertamente, em público. Afinal, esse é um blog feito por muitas mãos, olhos, cérebros, dedos, pernas, ouvidos, pulmões e corações. Uma colcha de retalhos que dialoga por meio de diversas vozes, opiniões, pensamentos e personalidades.

Tudo que aqui está publicado é responsabilidade nossa, como coletivo. A proposta atual é fazer um espaço virtual mais amplo e democrático. Entendemos que mesmo buscando a pluralidade erramos em alguns momentos. Portanto, vasculhando os arquivos é possível encontrar textos com vestígios racistas, gordofóbicos, transfóbicos, classistas, capacitistas, lesbofóbicos, bifóbicos, homofóbicos, entre outros preconceitos tão arraigados em nós. Há também a questão da invisibilidade, na maioria de nossos textos damos voz a mulher branca, heterossexual, cissexual, de classe média.

Não acreditamos em estereótipos. Não acreditamos em verdades absolutas. Não acreditamos no feminismo como uma cartilha e nem como religião. Nosso feminismo é político e está constantemente em construção. Aberto para agregar ideias, valores e conceitos. Pronto para reconhecer privilégios e contradições. Disposto a questionar universalizações e essencialismos. Temos o desafio de propor, lutar e implementar mudanças sociais que construam uma sociedade melhor para TODAS as pessoas.

Como podemos notar nesta definição há uma busca de identidade que se consolida em blogs autorais que estão reunidos neste Portal. De certa forma, há nesta comunidade ou conjunto, "[...] falas e conversações, questões ou respostas, explicações ou esclarecimentos" (DELEUZE; GUATTARI, 1996, p. 70). Há uma escritura autoral para marcar e definir uma máscara, consolidada no perfil do autor e no desenho do blog de cada um deles ou delas.

A segunda linha ou linha molecular é aquela que põe as coisas em jogo de forma inquietante, interior e exterior se esparramando de forma rizomática, repleta de devires. Por essa linha o cartógrafo se aproximou das postagens do blog Sapatilhando e da sua autora, para analisar a riqueza da sua máscara e sua capacidade de se expandir formando novos territórios, fazendo vibrar outros corpos pela força da sua escrita e pela riqueza simbólica das imagens empregadas. Aqui a cartografia se deu na análise dos micromovimentos, nas relações travadas entre autora e leitores das postagens do blog autoral. Buscando perceber a imanência na sua dimensão micropolítica, nos seus pequenos pedaços que afloram ao longo dos processos de dialogia do contar do si para escutar o contar do outro. 
Esta linha molecular tem como característica, segundo Rolnik (1989), expor as pequenas fissuras, as micro-rachaduras que gradativamente se expandem, gerando novas configurações e mundos novos. Nesta linha o cartógrafo pôde capturar nos silêncios do discurso, na simbologia das imagens e dos sons, as configurações subjetivas se transformando e novas identidades emergindo.

A terceira linha, a linha de fuga ou ruptura, a qual Rolnik (1989) denomina de linha dos afetos porque ela se posiciona na tensão máxima entre os corpos, um fluxo que nasce nesta relação de um corpo com outro corpo. E destas relações novos campos sociais se configuram, aqui a cartografia se faz nas devolutivas das experiências de vida relatadas pelos leitores do blog Sapatilhando e transformadas depois de compartilharem suas histórias e suas descobertas a partir do contato com a Blogosfera, porque o blog Sapatilhando é um hipertexto, um rizoma que se liga em redes a outros blogs e a outros portais, em um infinito devir social. Veja figura abaixo:

Figura 4 - Linhas Cartográficas

- Como linha molar, aquela que representa os conjuntos sociais e institucionais e os relacionamentos entre as pessoas, o movimento de mulheres no seio da blogosfera se organizando como sujeito social.

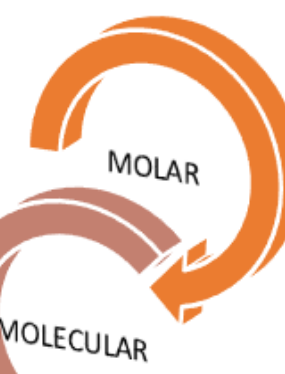

- Como linha molecular temos aquela que põe as coisas em jogo de forma inquietante,

- A linha dos afetos se posiciona na tensão máxima entre os corpos, um fluxo que nasce nesta relação de um corpo com interior e exterior se esparramando de forma rizomática, repleta de outro corpo. E destas relações novos campos sociais se configuram.

O Método Cartográfico representa o modo de composição das redes a partir destas linhas no seu emaranhado geométrico. Este se configura em um plano de imanência, que Deleuze diz ser um plano no qual "[...] estão todos os corpos, todas as almas, todos os indivíduos" (DELEUZE, 2002, p. 127). 
O plano de imanência, para o autor, é reconhecido, à medida em que, se aventura no cotidiano da vida, fundamento da análise cartográfica, o plano no qual os corpos, aqueles todos em potência que afetam e podem ser afetados, se percebem concomitantemente e compõem a realidade humana. Para Deleuze, (2002) "[...] nunca, pois, um animal, uma coisa, é separável de suas relações com o mundo: o interior é somente um exterior selecionado; o exterior, um interior projetado" (p.130).

A noção de sujeito considerada nesta tese e que embasa a Cartografia está na dimensão de corpo, que se estabelece a partir dos conceitos de longitude e latitude. Conceitos assim definidos:

Tomando emprestados termos da Idade Média, ou então, da geografia, nós o definiremos por longitude e latitude. Um corpo pode ser qualquer coisa, pode ser um animal, pode ser um corpo sonoro, pode ser uma alma ou uma ideia, pode ser um corpus linguístico, pode ser um corpo social, uma coletividade. Entendemos por longitude de um corpo qualquer conjunto das relações de velocidade e de lentidão, de repouso e de movimento, entre partículas que o compõem desse ponto de vista, isto é, entre elementos não formados. Entendemos por latitude o conjunto dos afetos que preenchem um corpo a cada momento, isto é, os estados intensivos (DELEUZE, 2002, p. 132).

Diante dos devires que constituem as subjetividades, a cartografia vai esboçando mapas. Mapas que desenhem a rede de forças à qual o objeto ou fenômeno em análise está conectado, tentando dar conta de entender suas modulações e o seu movimento permanente. Nesta construção em dobras ou camadas semióticas que constitui a realidade, que corpos subjetivos, individuais ou coletivos, estão se mutando a cada instante para o plano social.

O fenômeno cartografado nesta tese tem uma profunda implicação com a história do cartógrafo, com o seu se fazendo, enquanto aquele que escuta e que se pronuncia, que vivencia momentos de tensão, de ruptura, de continuidade e de contradições frente ao modelo teórico escolhido e em desenvolvimento. Esses conflitos proporcionam o surgimento de novas zonas de sentido, que, consequentemente, provocam avanços na construção teórico-metodológica da pesquisa e na compreensão da subjetividade dos sujeitos envolvidos no processo de pesquisa.

Sabemos que o cartógrafo está diretamente ligado à sua organização subjetiva, cada ser é único, impossibilitando a geração de um conhecimento que 
seja caracterizado como universal. Ao desenvolver um trabalho cartográfico, há uma grande responsabilidade de estar atento à própria criatividade, à flexibilidade e à capacidade de perceber-se como sujeito da pesquisa, uma vez que ele representa neste momento um núcleo gerador de pensamento que o torna inseparável daquilo que pesquisa. Tal responsabilidade está ligada ao conhecimento produzido, uma vez que se torna autor e sujeito da produção do conhecimento.

Assim, ao observar as linhas cartográficas é evidente a necessidade cada vez maior de observação do sujeito, sua filosofia pessoal e suas experiências, capazes de contribuir para um novo conhecimento de sentido subjetivo que se torna fato real sempre em devir.

Para adentrarmos nessa dimensão interpretativa a partir dos sentidos subjetivos, faz-se necessário considerar e compreender os diferentes tipos de instrumentos que podem colaborar na leitura desse processo cartografado. Optamos pela dinâmica conversacional e dialógica, para mergulharmos na visão de mundo e configurações subjetivas da autora do blog Sapatilhando cartografada neste estudo.

Partimos nesta escolha, do princípio de que a conversação desperta o sentido subjetivo do sujeito por meio da significação de sua experiência pessoal, através da sua fala reflexiva. Buscando-se com isso, o surgimento de novos processos simbólicos e afetivos. Nesta dinâmica conversacional teremos condições de alcançar a trama de sentidos subjetivos no emaranhado das linhas que desenham os territórios existentes e os novos territórios delineados.

Nos fenômenos que estudamos também há muito do que somos e do que fazemos. Nosso olhar de cartógrafo está contaminado pelas epistemologias que nos constituíram.

Para diferentes discursos e diferentes suportes textuais, inclusive a hipermídia aqui estudada, faz-se necessário trazer para o círculo metodológico, a semiótica aplicada estudada e utilizada por Santaella (2007) quando se trata de fenômenos discursivos no âmbito das linguagens líquidas.

Como já afirmamos anteriormente neste trabalho, no texto eletrônico nenhum estado ou versão é definitivo porque a cada leitura de quem o acessa novos caminhos podem ser trilhados e uma nova cartografia de leitura pode ser definida. 
Os hipertextos são obras abertas e em movimento e a medida que são compartilhadas novas postagens pelos leitores, novas leituras podem ser realizadas.

Para Bairon (2012), a hipermídia é a linguagem não-linear que atua de forma multimidiática e tem sua origem conceitual no jogo. "No aspecto filosófico, a linguagem hipermídia, quando compreendida como um jogo, assume o princípio de que linguagem e ser são sinônimos, o que é proporcional a afirmar que jogar é ser jogado" (BAIRON, 2012, p. 8).

Quando no referencial teórico do nosso trabalho apontamos a diferença entre ler um texto escrito e ler um texto digital, trazemos para análise o movimento transgressor desta produção. Segundo Bairon (2012), na leitura da letra transformamos em som toda palavra lida, na leitura digital podemos transformar em leitura o som, em imagem a leitura, em movimento a imagem, em arte a forma de pensar tradicional e vice-versa. Com isto o leitor realiza múltiplas e superlativas leituras. Atrelado a isso cresce a multiplicação de sentidos e a quantidade de informações. Este crescimento demanda também um maior número de filtros para que a comunicação aconteça.

Para a leitura do blog Sapatilhando, definimos como filtro de análise as categorias piercianas, adotadas por Santaella (2007a): a primeiridade, a secundidade e terceiridade.

A primeiridade se caracteriza por qualquer qualidade de sensação, a que não possui relação com outra coisa. É a categoria do imediato. A secundidade diz respeito às relações, ações e reações ainda em um nível de relação dialógica, independente de leis. A terceiridade por sua vez, é a interpretação dos fenômenos mediante algum princípio lógico estabelecido na razão, determinando uma regra.

O hipertexto Sapatilhando está ancorado em um blog online, composto portanto, por signos que intentam representar a subjetividade e os devires de autora e leitores, mediante o hibridismo das linguagens que o constitui. Portanto, as três categorias relatadas estão presentes.

A primeiridade presencia-se no contato imediato do usuário/leitor com a página do blog. Analisamos portanto, as impressões sensoriais advindas das cores, formas e diagramação. A secundidade faz a análise das relações que se fazem a partir das características subjetivas observadas na primeiridade. Nesta etapa já se 
inicia a interpretação dos fenômenos. Na terceiridade, o geral é que se faz presente, a cultura do leitor/usuário que está acessando o blog e a interpretação que o mesmo obtém das qualidades que observamos e sentimos das relações criadas.

O método semiótico se presta ao estudo de corpos em movimento e com ele podemos identificar características sintáticas, semânticas e pragmáticas de hipermídias digitais. Vemos esta hipermídia como signo e tendo como norte as categorias piercieanas podemos traçar os mapas estratégicos de leitura:

1. Mapa sensorial - signo como qualidade- aqui traçamos tudo que percebemos nos elementos visuais (cores e formas), verbais(tipografias) e sonoros(áudios, elementos musicais) do signo. Para este mapa traçamos as linhas interrogativas:

- Quais as qualidades que o fazem signo? O que faz este signo perceptível? O que ele intenta significar? Quais as intenções do designer e que público ele pretende atingir? Enfim, as possibilidades de significação existentes.

2. Mapa relacional - o signo como existente - Nesse momento da análise nos detemos nas conexões (possibilidades de novos mapas, hiperlinks, rizomas possíveis que favoreçam a intertextualidade no seio da Blogosfera em que o Sapatilhando está inserido. Para este mapa as linhas interrogativas são:

- Em que contexto está inserido o blog? Qual sua relação com o Portal Blogueiras Feministas? Quais as possibilidades de navegação que o Sapatilhando propicia ao leitor? Quais as outras janelas e percursos para os quais ele permite navegar? Como o leitor percebe o blog e interagem com sua interface e seus dispositivos digitais?

3. Mapa interpretativo - o signo em sua generalidade - Traçamos nesta dobra de sentido, os elementos internalizados em regras e leis. Quais as interpretações gerais encontradas? A interpretação dos leitores vem ao encontro do que idealizou a autora do blog? Há outras janelas de interpretação para esta hipermídia? 
Na obra Semiótica Aplicada apresentada por Santaella (2007a), os signos podem e devem ser estudados também, sob três aspectos que determinam sua natureza e que acompanham os níveis de percepção. $\mathrm{Na}$ apreciação objetiva os signos na hipermídia estudada, são observados como ícones, como índices ou símbolos.

Os ícones estão diretamente ligados à observação da primeiridade captada pelos nossos sentidos, nesse bojo estão as imagens, os diagramas e as metáforas. Os índices por sua vez, dão pistas sobre a realidade, nos permitindo fazer as associações e relações típicas da secundidade peirceana. Por último, temos os símbolos que são signos na sua completude, por terem sido consensualmente pactuados sobre a realidade e com o passar do tempo se cristalizam em leis. Aqui reside a riqueza da interpretação da terceiridade.

Podemos com esta explicação reafirmar que a análise semiótica é um estudo, fruto de uma percepção do pesquisador e da sua compreensão subjetiva e única.

A hipermídia analisada, neste estudo, é resultado da interação de signos comuns com um referente percebido subjetivamente por cada interpretador. Desta forma também, somos obrigados a levar em conta todas as variáveis do contexto onde foi produzida esta hipermídia, a fim de entendermos não apenas o seu desenho na tela digital, mas também os fatores que a determinam, os modos como são recebidas as postagens veiculadas, a natureza e o porquê dos efeitos de sentido que podem causar em seus receptores.

Figura 5 - Signos e suas tipologias

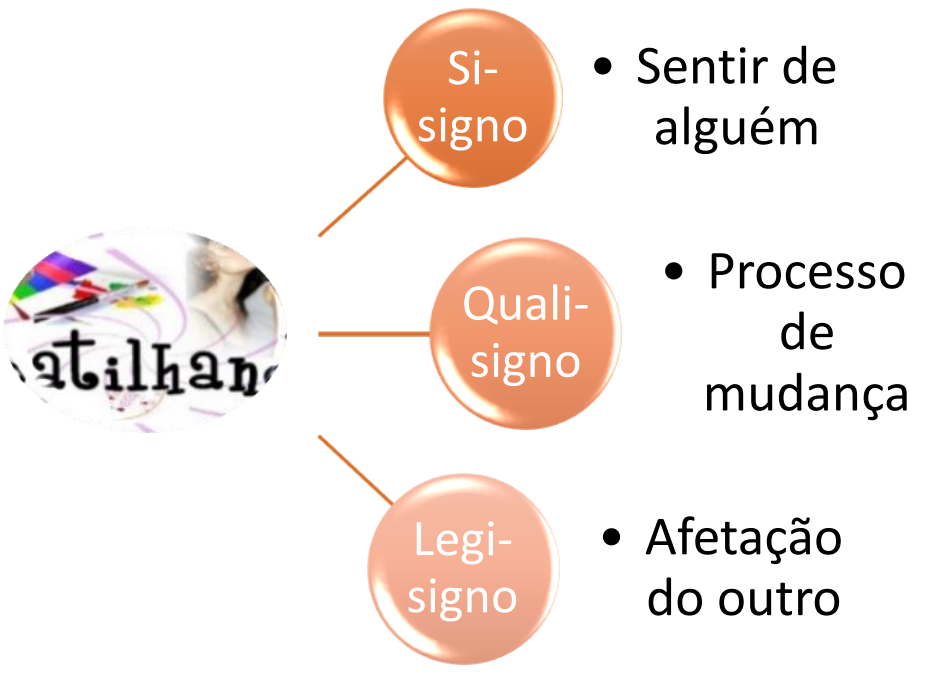


III SEÇÃO CONSTRUTIVA - INTERPRETATIVA 


\section{CAPÍTULO 3.1 SAPATILHANDO - A CARTOGRAFIA}

Toda análise de dados demanda reflexão e silêncio. Quando os dados são narrativas autorais, o sujeito cartógrafo se envolve nas linhas e delineia mapas para encontrar seu caminho, iluminado pelas indagações e pelos mergulhos subjetivos em si mesmo. É um dentro de si que se abre a um dentro de outro.

Ler uma dada realidade ou fenômeno da construção da subjetividade é um trabalho de cartografia e quando os caminhos a serem percorridos estão inscritos em paisagens psicossociais, o cartógrafo inicia sua viagem de descoberta percebendo que o real está imbricado com o social e há entre eles uma interdependência inexpugnável. Como afirma Rolnik (2007), são os movimentos do desejo, sejam eles visíveis ou invisíveis que produzem o real social:

As cartografias vão se desenhando ao mesmo tempo (e indissociavelmente) em que os territórios vão tomando corpo: um não existe sem o outro. Concluindo: a produção do desejo, produção de realidade, é ao mesmo tempo (e indissociavelmente) material, semiótica e social (p. 46).

Para a leitura do blog Sapatilhando tomei como lupa da escrita de si os estudos de Deleuze e Guattari (1996; 2010), tendo como ferramenta auxiliar de análise, os estudos de releitura da semiótica peirceana de Santaella (2001; 2007; 2007a; 2011) sobre a dimensão semiótica na produção das diversas linguagens presentes no diário eletrônico, assim desenhei as linhas molar, molecular e de fuga ou ruptura na narrativa hipertextual que ali se configurou, metaforicamente seria como os percursos de uma borboleta nos seus estágios de evolução. Em seguida, busquei fazer a leitura dos mapas e territórios definidos nesse processo de subjetivação e veio como parceiro nesta jornada os estudos bakhtinianos.

E como os territórios e mapas são percursos que se transmutam e se espraiam quando em contato com outros territórios e suas latitudes, busquei como norte o pensamento freireano naquilo que ele discute como círculo de cultura para cartografar as relações entre a autora e seus leitores. Suas aprendizagens, suas descobertas, seus significados e suas significações rizomáticas e dialógicas. Para isso, Bakhtin vem se juntar a conversa, nesse círculo de autores que se reuniram para de mãos dadas darem corpo e voz a esta tese que nasce sob o signo da 
palavra compartilhada, no processo educativo da sua autora que se educa, educando na labuta de escrever.

\subsubsection{Helena Paix - a cartografia de uma subjetivação pulsante}

Início a cartografia de Sapatilhando partindo do sujeito virtual Helena Paix que escreve, da Sapatilha personagem que se desenha e ganha voz. Sapatilhando, em gerúndio: ser que evolui em constante inacabamento.

Figura 6 - Identidade visual/Banner do blog ${ }^{18}$

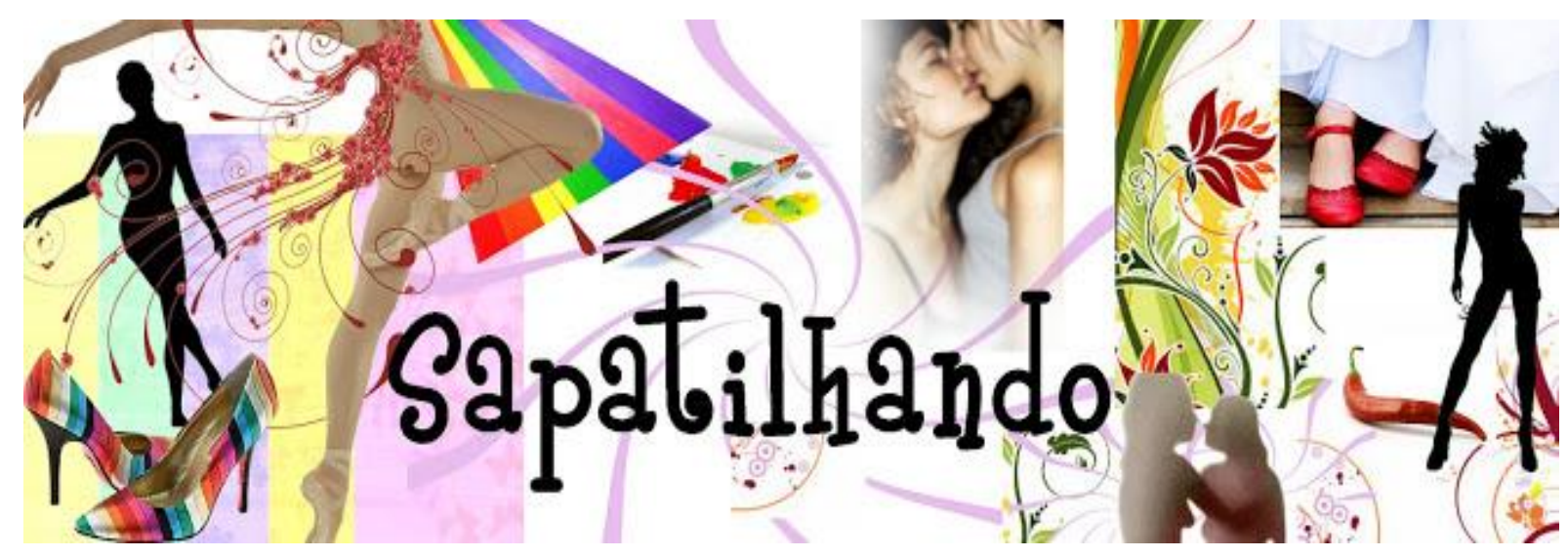

\footnotetext{
${ }^{18}$ Disponível em: http://www.sapatilhando.com.br/. Acessado em: 15 mar. 2012.
} 
Figura 7 - Helena Paix ${ }^{19}$

:::dona das sapatilhas:::

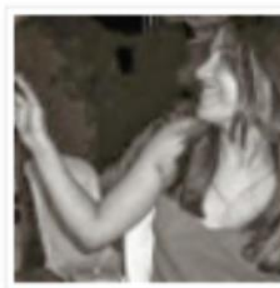

Q Helena

Eu sou um pouco de algumas coisas: um pouco escritora, um pouco tradutora, um pouco jornalista, um pouco pesquisadora, um pouco cozinheira, um pouco professora...

A sorte é, quero crer eu, que quando a gente junta um monte de poucos, até que a soma fica legal.

De toda forma sou também uma mulher que perto dos 30 anos decidiu finalmente ouvir e dançar a dança que sempre quis: uma dança de sapatilhas. $E$ o percurso desde então tem sido cheio de beleza e aprendizados! Deixo aqui os pensamentos, dúvidas, certezas, sorrisos e lágrimas desse caminho de descobertas e desafios.

Sobre a vida em geral, acredito que sempre imprimimos um pouco de quem somos em tudo o que fazemos, e realmente acho que estamos aqui para deixar que o tempo nos melhore: para deixar que ele nos mude por dentro como inevitavelmente nos transformará por fora.

|| Queridas mulheres-sapatilhas: vamos dar a mão e dançar juntas? :] Sejam todas bemvindas!

${ }^{19}$ Observamos que a denominação Helena Paix é um pseudônimo, um "perfil virtual", utilizado em redes sociais e/ou blogs. Disponível em: http://www.sapatilhando.com.br/. Acessado em: 15 mar. 2012. 
Analisamos um diário eletrônico que tem uma face inicial em 2008 e que se transmuta até 2014. Há um percurso transcorrido, mudanças registradas. Há repetições temáticas, mudanças na construção das postagens, introdução de novos elementos e recursos.

A Helena que se apresenta no perfil do blog, mostra uma construção como num vitral, pedaços de si que se iluminem em um todo:

Eu sou um pouco de algumas coisas: um pouco escritora, um pouco tradutora, um pouco jornalista, um pouco pesquisadora, um pouco cozinheira, um pouco professora...

A sorte é, quero crer eu, que quando a gente junta um monte de poucos, até que a soma fica legal.

Esta Helena vibra diante do fato de assumir a necessidade de enfrentar seus medos e se permitir dançar com suas sapatilhas, assim ela se constitui como corpo vibrátil na perspectiva de Guattari, que deseja e busca realizar e expandir seu desejo, como entende que seu percurso se dá de forma educativa. Uma Helena que prima pela presença da palavra em suas várias faces, desde aquela que escreve de modo autoral, como aquela que busca a informação, a que interpreta dados e que experimenta colocar em prática suas descobertas culinárias, quiçá recriando receitas. Nesta soma se apresentam as multiplicidades de uma subjetivação que se constitui:

As multiplicidades são a própria realidade, e não supõem nenhuma unidade, não entram em nenhuma totalidade e tampouco remetem a um sujeito. As subjetivações, as totalizações, as unificações são, ao contrário, processos que se produzem e aparecem nas multiplicidades (DELEUZE; GUATTARI, 1996, p.10).

Entre 2008 e 2009 as postagens se constituem em uma abertura para a escrita, e a autora, avisa ao leitor, que todo início é fruto de uma gestação, de um processo que vem de dentro para fora, e que realiza movimentos: 


\section{| A DESCOBERTA OU VIRANDO BORBOLETA |}

Tudo o que é grande começa devagarzinho. Pequenino, pequenino. Repetido. Timidamente você escuta uma voz lá longe... percebe algo. Esquece que percebeu. A voz teima, teima... vai crescendo teimosa: até que você começa a escutá-la.

Primeiro, como um sussurro.

E o sussurro, já sabem, acelera o coração.

Dá medo. Um medo tipo esconde-esconde: ora excitante, ora verdadeiramente assustador.

E você distrai a mente, pensa em outra coisa, se ocupa. Daqui a pouco, finge que esqueceu. Mas finge tão descaradamente que a máscara um dia cai e a voz - que nunca desistiu de sussurrar - é escutada.

E aí é como quando a gente derruba o prato de comida: um barulho horrível e uma bagunça grande acontece dentro da gente.

0 passo seguinte é perceber essa bagunça e lidar com ela.

É ter a consciência que se você deixar lá o prato quebrado e a comida no chão as coisas só irão piorar...

Dai você vai trabalhando isso na sua cabeça. Da sua forma e velocidade. E chega um dia se você for amigo verdadeiro de si mesmo - que você está pronto pra fazer essa grande faxina. Dai você respira fundo e começa a enfrentar essa coisa-enorme-e-teimosa que é "a voz lá de dentro", que é o seu sentir.

Para mim foi assim: um processo.

Foi não: está sendo.

Ainda é tudo muito novo e ao mesmo tempo é tudo muito antigo.

Antigo demais até.

Gosto de pensar que nós, seres-coloridos; nós, mulheres-sapatilhas, somos seres encantados, que passam por diferentes estágios de encantamento ao longo da vida:

II algo como:

$\sim$ temos a fase de MINHOCA:

Rastejamos de vagarzinho, olhando tudo muuuuito lentamente, nos alimentando e esperando pacientemente por uma outra vida, uma outra existência, uma versão de nós mesmas que está guardada: uma versão mágica em que olhemos para o espelho e nos reconheçamos por fora, como nos vemos por dentro. Olhamos para nosso corpo de minhoca e não gostamos: há algo errado, há algo que não bate, que não é como deveria. Esse incômodo vai crescendo até que por fim estamos prontos para entrar na fase seguinte.

$\sim$ temos a fase de casulo: 
Já percebemos que não temos vocação para minhoca. Já nos tocamos que somos diferentes. Que é hora de contar a verdade pelo menos para nós mesmas: há outra versão de nós que é muito mais bonita, porque é a nossa versão verdadeira. E aí sabe o que fazemos? Preparamos um casulo aonde possamos, pouco a pouco assumir nossa beleza. A fase do casulo é mais longa, porque é uma fase-carregador: temos que fortificar a coluna, temos que construir uma auto-base, uma auto-edificação-de-si-mesma. Temos que dar em si mesma um abraço loooongo, um abraço constante, um abraço eterno. Temos que perceber que somos fortes, que agüentamos o tranco, que somos especiais porque damos conta de sermos assim.

I a fase do casulo é a fase de construção. Ela pode ser super rápida para alguns, e muuuuito longa para outros. o mais importante é respeitar essa fase. é ela que vai the dar forças para a fase seguinte.

$\sim$ temos a fase da BORBOLETA:

A fase da borboleta acontece quando estamos prontos para deixar o casulo. Isso não significa necessariamente assumir para todos: significa assumir principalmente para você mesma. A fase borboleta é mais bela: você olha no espelho e se reconhece: você sabe da sua beleza e do seu colorido.

I como todo ser que voa, aprendemos, que nem-tudo-são-flores. Há muitas redes aí de colecionadores de borboletas: pessoas que não querem que você voe, vendavais que the arrastam de sua direção, chuvas torrenciais que ensopam suas asas, águias que tentam the capturar e the ferir.

É hora de ser forte. De ter mais do que nunca, certeza da borboleta linda que você é. Do encantado do seu colorido. Da sua capacidade de voar enfeitando o ar com rodopios.

É hora de saber por onde voar: que vôos the trarão sorrisos, que vôos the trarão dores. É hora de pousar só em árvores conhecidas. É hora de perceber que você voa porque é seu destino voar: mesmo que outros seres não entendam nada sobre vôo.

É hora de ter orgulho de ter conseguido ser quem você sempre esteve predestinado a ser: uma linda borboleta colorida.

E sabe o quê?

- 0 que é um campo de flores sem borboletas voando sobre elas?

Nós, queridas, nós somos a poesia que voa com o vento.

E essa certeza não podemos esquecer jamais.

I I I apresentando, a Sapatilha. Personagem que criei e que me acompanhará nessa dança-descoberta: 


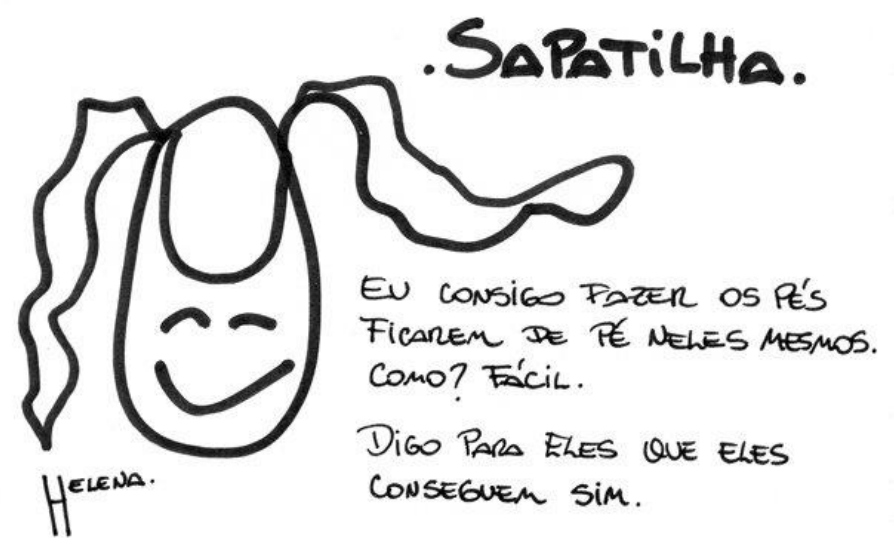

Nessas duas postagens, Helena Paix desenha seu primeiro mapa, traça uma geografia que irá se desenvolver ao longo das postagens subsequentes. Estamos diante de um cenário que irá se posicionar em três atos. Uma Helena em três fases. Um movimento e um devir que necessariamente não acontecerá de maneira estanque e subsequente, porque há movimentos de vai e vem nessa trajetória. Avanços e recuos.

Como Ronilk relendo Guattari em Cartografia Sentimental (2007), buscamos entender o processo de produção dos universos psicossociais que a autora delineia.

O corpo vibrátil de Helena aponta para a possibilidade de em um primeiro movimento, o de minhoca, no qual observa e espreita à espera de um novo momento, uma nova magia, que transforme seu ser rastejante, inseguro e incerto em algo maior e mais potente:

Rastejamos devagarzinho, olhando tudo muuuuito lentamente, nos
alimentando e esperando pacientemente por uma outra vida, uma outra
existência, uma versão de nós mesmas que está guardada: uma versão
mágica em que olhemos para o espelho e nos reconheçamos por fora,
como nos vemos por dentro. Olhamos para nosso corpo de minhoca e não
gostamos: há algo errado, há algo que não bate, que não é como deveria.
Esse incômodo vai crescendo até que por fim estamos prontos para entrar
na fase seguinte.

No momento seguinte, no movimento de casulo, Helena acredita que é o burilamento da nova pessoa que se reconhece uma zona de intensidade contínua, como integrando um plano de composição, um platô que almeja a criação de novos territórios psicossociais. 
A fase do casulo é mais longa, porque é uma fase-carregador: temos que fortificar a coluna, temos que construir uma auto-base, uma auto-edificaçãode-si-mesma. Temos que dar em si mesma um abraço loooongo, um abraço constante, um abraço eterno. Temos que perceber que somos fortes, que aguentamos o tranco, que somos especiais porque damos conta de sermos assim.

Deleuze e Guattari (1996) descrevem esse processo de modo muito claro quando afirmam:

Os princípios característicos das multiplicidades concernem a seus elementos que são singularidades; as suas relações, que são devires; os seus acontecimentos, que são hecceidades (quer dizer, individuações sem sujeito); a seus espaços-tempos, que são espaços e tempos livres; a seu modelo de realização, que é o rizoma (em oposição ao modelo de árvore); a seu plano de composição, que constitui platôs (zonas de intensidade contínua); aos vetores que as atravessam, e que constituem territórios e graus de desterritorialização (p.10-11).

$\mathrm{Na}$ fase borboleta, estamos diante de uma Helena que narra um processo de autoconhecimento, de certeza. Refere-se ao movimento de voar e faz constante referência ao vento e define as mulheres-borboletas como ela, como sendo aquelas que são a própria poesia. Esse paralelismo com a construção poética se aproxima muito da discussão que Deleuze e Guattari (1996) fazem sobre escrever, como um ato de manifestação das multiplicidades que nos habitam:

Escrever nada tem a ver com significar, mas com agrimensar, cartografar, mesmo que sejam regiões ainda por vir. [...] Escrever a n, n-1, escrever por intermédio de slogans: faça rizoma e não raiz, nunca plante! Não semeie, pique! Não seja nem uno nem múltiplo, seja multiplicidades! Faça a linha e nunca o ponto! A velocidade transforma o ponto em linha! Seja rápido, mesmo parado! Linha de chance, jogo de cintura, linha de fuga (DELEUZE; GUATTARI, 1996, p.49).

Para os autores, o rizoma se coloca como um inter-ser que é acompanhado das conjunções aditivas e, e, e. Movimentos somativos que se expandem e rompem com as perguntas fundantes da nossa cultura do de onde viemos para onde vamos. Pensam o movimento e o processo de subjetivação como uma outra maneira de viajar ou voar no dizer de Helena. O movimento parte do meio, porque é nele que a velocidade ganha força, como bem descreve Helena ao falar sobre a fase casulo. Portanto, o conceito de terminalidade e finitude não tem lugar no pensamento dos autores:

O meio não é uma média; ao contrário, é o lugar onde as coisas adquirem velocidade. Entre as coisas não designa uma correlação localizável que vai 
de uma para outra e reciprocamente, mas uma direção perpendicular, um movimento transversal que as carrega uma e outra, riacho sem início nem fim, que rói suas duas margens e adquire velocidade no meio (DELEUZE; GUATTARI, 1996, p.49).

As fases apontadas por Helena de maneira metafórica apontam para uma consciência de processo, de movimento e reconhecimento de si, movimento que se propõe no diálogo com suas leitoras potenciais.

A escrita de si apresenta então, uma finalidade de compartilhamento de experiência, concretizando o pensamento de Deleuze e Guattari (1995) quando afirmam que não existe enunciado individual, porque todo enunciado é o produto de um agenciamento maquínico, resultante de agentes coletivos, entendidos como multiplicidades:

O nome próprio não designa um indivíduo: ao contrário, quando o indivíduo se abre às multiplicidades que o atravessam lado a lado, ao fim do mais severo exercício de despersonalização, é que ele adquire seu verdadeiro nome próprio. O nome próprio é a apreensão instantânea de uma multiplicidade. $O$ nome próprio é o sujeito de um puro infinitivo compreendido como tal num campo de intensidade (DELEUZE; GUATTARI, 1996, p. 66).

Desta feita, podemos entender que o perfil Helena Paix não foi uma escolha aleatória, o nome indica o desenho de um arquétipo mitológico feminino que simboliza beleza e ao mesmo tempo capacidade de revolucionar, porque leva o povo grego a uma guerra. Paix por sua vez vem fazer o contraponto. O perfil é uma bela revolução apaziguadora. Possivelmente, uma revolução íntima que se expõe e cria uma dada realidade a partir desta exterioridade. Helena Paix é um rosto que se apresenta, é uma sapatilha personagem e signo:

Figura 8 - Personagem e signo - Helena Paix
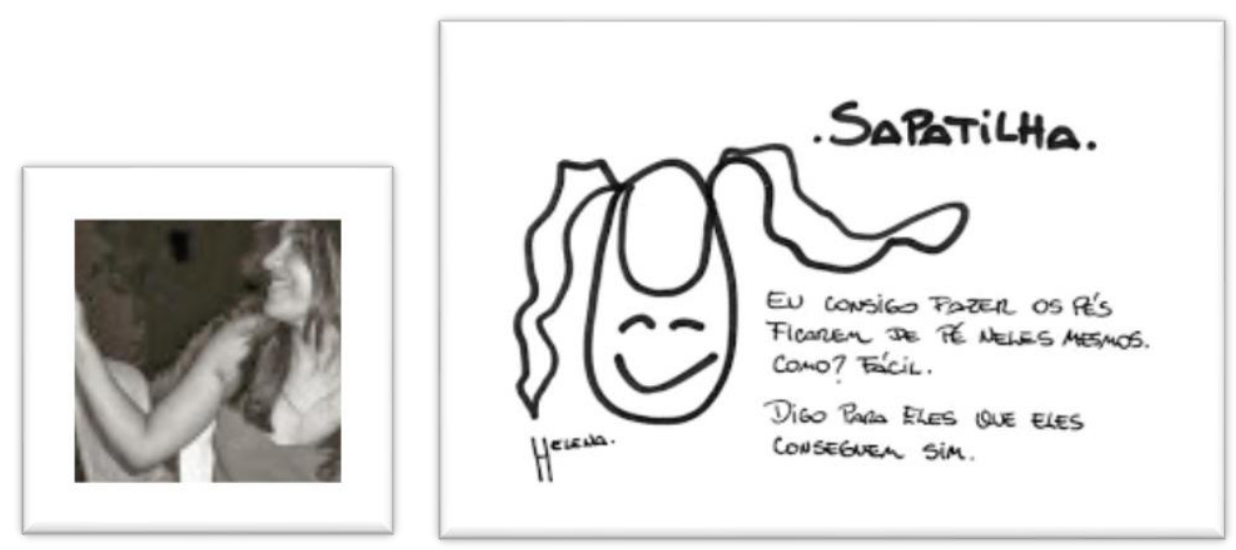
Quando Deleuze e Guattari (1996) fazem a discussão sobre o rosto e a subjetividade, vale ressaltar que o rosto não é um invólucro exterior àquele que fala:

Os rostos (perfis) não são primeiramente individuais, eles definem zonas de frequência ou de probabilidade, delimitam um campo que neutraliza antecipadamente as expressões e conexões rebeldes às significações conformes. Do mesmo modo, a forma da subjetividade, consciência ou paixão, permaneceria absolutamente vazia se os rostos não formassem lugares de ressonância que selecionam o real mental ou sentido, tornando-o antecipadamente conforme a uma realidade dominante. [...] O rosto é um mapa, mesmo se aplicado sobre um volume. [...]

É precisamente porque o rosto depende de uma máquina abstrata que ele não se contentará em recobrir a cabeça, mas afetará outras partes do corpo (DELEUZE; GUATTARI, 1996, p. 36).

A discussão proposta por Helena Paix, um perfil ou um rosto que desencadeia o relato dialógico de sua subjetivação no Blog Sapatilhando, se abre para ser exposto com o objetivo de ser desfeito e tomar nova forma, abrir-se para uma construção coletiva com outros rostos, em busca de um rosto coletivo, portanto, a-subjetivo que assuma a luta pelo direito a ser multiplicidades femininas. Assim, "[...] o rosto escava o buraco de que a subjetivação necessita para atravessar, constitui o buraco negro da subjetividade como consciência ou paixão, a câmera, o terceiro olho" (DELEUZE; GUATTARI, 1996, p. 36).

Essas multiplicidades femininas que são de Helena e de tantas outras mulheres, inclusive suas leitoras, não deixam que se passe despercebido o sentimento de medo que esta escolha, a da escrita de si, desencadeia na autora do blog. Um ano depois do blog publicado e visitado, em 2009, Helena posta mais uma declaração sobre como se sente diante da escolha que fez, a escolha de contar de si para se unir a outras tantas Helenas que estão no mundo: 


\section{Da série: Meu testemunho sobre Homossexualidade e Família}

Olá, minhas queridas e queridos!

Obrigada àqueles que deixaram recadinhos por aqui e àqueles que me escreveram emails... 0 apoio de todas(os) vocês sempre foi a razão de eu manter este blog e de escrever os textos que escrevi.

Eu não falei por aqui, mas o Sapatilhando fez um ano de vida em Outubro!!

Sim, um ano de passou desde que esta 'Helena' aqui, assustada e sozinha, fez este blog para

lidar melhor com sua homossexualidade.

Ao longo desse tempo, acabei sendo ajudada muitas vezes e as histórias de vocês se confundiam com a minha: afinal nossos conflitos são, tantas vezes, os mesmos -- da descoberta, à auto-aceitação, ao lidar com as coisas do cotidiano, do amor e, principalmente, da familia.

Como se percebe nesta postagem, Helena enumera seus conflitos e medos: a descoberta de si, a auto-aceitação, lidar com o cotidiano, o amor e destaca a família.

Esses conflitos definem muito o processo que a autora vive. Se observarmos bem, há aqui claramente os quatro perigos existenciais descritos por Deleuze e Guattari, que retomamos aqui: o Medo de perder, a Clareza, o Poder e o Grande Desgosto. Esses quatro perigos trazem em seu bojo os medos descritos pela autora do blog Sapatilhando:

Tememos, o tempo todo, perder. A segurança, a grande organização molar que nos sustenta, as arborescências onde nos agarramos, as máquinas binárias que nos dão um estatuto bem definido, as ressonâncias onde entramos, o sistema de sobrecodificação que nos domina - tudo isso nós desejamos. [...] Fugimos diante da fuga, endurecemos nossos segmentos, entregamo-nos à lógica binária, seremos tanto mais duros em tal segmento quanto terão sido duros conosco em tal outro segmento; reterritorializamonos em qualquer coisa, não conhecemos segmentaridade senão molar, tanto no nível dos grandes conjuntos aos quais pertencemos, quanto no nível dos pequenos grupos onde nos colocamos e daquilo que se passa conosco no mais íntimo ou mais privado (DELEUZE; GUATTARI, 1996, p.119). 
Esse sistema de sobrecodificação que domina a todos nós, domina Helena, mas ela luta contra ele lançando mão da palavra como arma. E esta arma possibilita que a revolução molecular se dê. E no blog Sapatilhando ela acontece na relação Helena autora com suas leitoras e leitores. São devires que se desenham, devires específicos.

O devir, segundo Deleuze e Guattari (2012) não é progredir ou regredir segundo uma série. Helena chama o devir animal-borboleta como se fizesse uma aliança e desta união ganhasse as qualidades e características do ser borboleta:

Devir é um rizoma, não uma é uma árvore classificatória nem genealógica. Devir não é certamente imitar, nem se identificar; nem regredir-progredir; nem corresponder, instaurar relações correspondentes; nem produzir, produzir uma filiação, produzir por filiação. Devir é um verbo tendo toda sua consistência; ele não se reduz, ele não nos conduz a "parecer", nem "ser", nem "equivaler", nem produzir (DELEUZE; GUATTARI, 2012, p.20).

O escrever é um devir para o autor, devir atravessado por diferentes devires, aproximando quem escreve do afeto, da capacidade de afetar e ser afetado, confirmando a vontade de ser coletivo, de ser bando, porque o eu só se reconhece como parte de algo. Helena não se conforma em ser borboleta, ela quer outras mulheres-borboleta como ela, alimentando o sentimento de coletivo, de panapaná. Um devir ancestral de se sentir pertencente a um coletivo, fonte da força e da vida:

Tudo o que está no céu e tudo o que está no inferno está dentro de você" Está tudo aqui, meninas.

Batendo dentro de mim.

Batendo dentro de vocês.

Eu teria que ter muito mais do que a pequena coluna que este blog me possibilita para conversar com vocês sobre isso. Aqui, qualquer textinho fica gigante. (ou seja, em outras palavras estou dizendo que a culpa é do blog, não minha! rs).

Mas Ihes digo no que eu creio: eu creio que a humanidade criou várias formas de assimilar o mundo, de tentar entender um pouco do que não dá para ser entendido. No meio disso tudo, coitados de nós, acabamos criando regras e normas e morais para ter menos elementos para serem entendidos.

E não previram que os seres lindos e coloridos ainda estariam ali: criando asas proibidas.

Eu tenho o mundo que eu enxergo.

$E$ eu luto por meu mundo a cada segundo que me é dado. Amo tanto a vida, amo tanto o que posso ter através da vida, que me dá calafrios saber que não tenho a certeza do próximo minuto. Por isso me 
ocupo e vivo e vivo. Com sede e segurança e certa, muito certa de mim. (Postagem de 20 fev. 2008) ${ }^{20}$

As multiplicidades de cada ser humano, segundo os autores, estão repletas de devires que de forma simbiótica reúne o devir tudo aquilo que nos une e nos constituí no universo, no âmbito animal, vegetal, do micro e macro da Natureza em sua enormidade. "Uma fibra vai de um homem a um animal, de um homem ou de um animal a moléculas, de moléculas a partículas, até o imperceptível. Toda fibra é fibra de Universo. Uma fibra de enfiada de bordas constitui uma linha de fuga ou de desterritorialização" (DELEUZE; GUATTARI, 2012, p.35).

Ao produzir o blog Sapatilhando, Helena realiza uma escrita de si, evocando a participação de outras mulheres, mulheres que também em processo de subjetivação, possam entender suas multiplicidades, porque essas são dinâmicas e seus devires se espraiam como rizomas e forma infinita. A cada postagem da autora, dezenas de respostas das leitoras recontando suas histórias e seus processos.

\begin{abstract}
Não é de se espantar, a tal ponto o devir e a multiplicidade são uma e mesma coisa. Uma multiplicidade não se define por seus elementos, nem por um centro de unificação ou de compreensão. Ela se define pelo número de suas dimensões; ela não se divide, não perde nem ganha dimensão alguma sem mudar de natureza (DELEUZE; GUATTARI, 2012, p. 34).
\end{abstract}

As relações traçadas entre a autora e as leitoras estão diretamente relacionadas com as relações que compõem cada ser humano, porque segundo os autores, essas relações correspondem às intensidades que o afetam, aumentando sua capacidade para mais ou para menos de agir, porque os afetos são devires. Assim, para Deleuze e Guattari (2012) a latitude de um corpo, os afetos de que ele é capaz dependem do grau de potência para ser afetado e afetar. "A latitude é feita de partes intensivas sob uma capacidade, como a longitude, de partes extensivas sob uma relação" (DELEUZE; GUATTARI, 2012, p. 44).

Dessa forma podemos afirmar que Helena se define pela sua latitude e longitude e não pelo fato de ter um corpo feminino apenas, um avatar feminino, mas sobretudo, pelo conjunto dos elementos materiais que the pertencem, pelas relações que trava, pela velocidade que se conecta e interage com suas leitoras, com sua escrita de si que provoca afetos e que a afeta. Este é o modo de individuação

\footnotetext{
${ }^{20}$ Publicação disponível em: http://www.sapatilhando.com.br/2008. Acessado em: 24 jun. 2014.
} 
diferente de uma pessoa, um sujeito, uma coisa ou substância. Para isto Deleuze e Guattari (2012) usam o conceito de hecceidade.

Uma estação, um inverno, um verão, uma hora, uma data, têm uma individualidade perfeita, à qual não falta nada, embora ela não se confunda com a individualidade de uma coisa ou de um sujeito. São hecceidades, no sentido de que tudo aí é relação de movimento e de repouso entre moléculas ou partículas, poder de afetar e ser afetado (DELEUZE; GUATTARI, 2012, p. 49).

Segundo os autores estas relações são hecceidades porque não são predicados, mas dimensões das multiplicidades que ocorrem em um plano que pode ser observado no tempo em suas durações: Kronos - tempo medido, Aion - tempo de longo prazo e vindouro, o tempo do devir e da anunciação e Kairós - bloco de tempo.

No plano da consistência no qual o humano se movimenta, Kronos quantifica os fatos e as ações, Kairós qualifica os acontecimentos e Aion eterniza o acontecer. Desta forma quando olhamos para a escrita de si de Helena, vemos que a autora elabora suas postagens e muitas vezes as enumera como numa sequência e também as nomeia, em outro momento ela mergulha em uma temática, como quando Sapatilhando se desdobra no ambiente virtual para o gênero epistolar, ao escrever uma longa carta aos pais, dela e todos os outros pais que se deparam com um filho ou filha discutindo sua identidade:

domingo, 29 de novembro de 2009

Da série: Meu testemunho sobre Homossexualidade e Família

Depois de chorar muito, escrevi a carta que disponibilizo abaixo (é suuuuper longa!! são OITO páginas de Word -- os textos que escrevo para cá em geral têm duas páginas). Para quem não quiser ler, peço que apenas terminem de ler essa 'introdução', pois quero fazer propaganda sobre alguns livros que são muito importantes para cada um de nós.

A carta que escrevi para eles, saibam, não foi a única. Fez parte de um processo. Depois dos absurdos que vieram do lado de lá, escrevi outra carta, muito mais enfática e imperativa, muito mais cheia de revolta pela falta de aceitação e pelas palavras e comportamentos deles.

Depois dessas cartas, depois de algumas doloridas conversas, depois de algum tempo, estamos começando a nos falar novamente. Eles são pais incríveis, que sempre me amaram e me apoiaram muito. Mas estão tendo sim muita dificuldade com tudo. E com certeza ainda temos um longo processo pela frente. Mas teimo em crer que o tempo e o amor restaurem (e até melhorem!!) o nosso relacionamento. ;] 
Figura 9 - Carta aos pais da autora de Sapatilhando (Anexo 1)

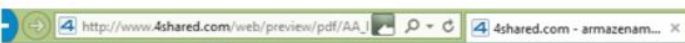
4shared F Baixar of Compartilhe tĩ Adicionar à minha conta

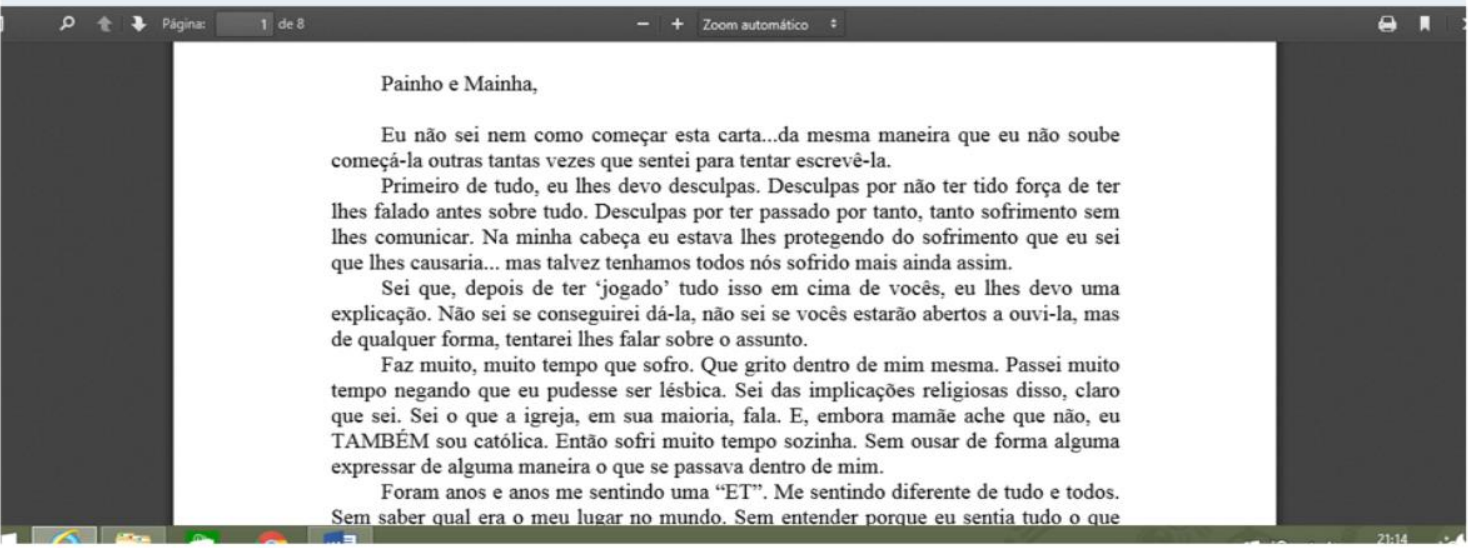

Em outro momento, a autora entende que o sagrado precisa estar envolvido na discussão da identidade, porque há outras problemáticas humanas envolvidas e ela percebe que há invocações a serem feitas, outras formas de manifestação e apoio ao processo de subjetivação das multiplicidades ${ }^{21}$ :

Hoje vamos falar sobre sonhos: sobre os teus sonhos e a importância de sonhar.

Um tema gostoso, não é mesmo?

Vamos conversar?

É só clicar no player abaixo:

Para baixar, clica AQUI.

Depois de escutar o programa, não esqueça de escutar mais uma vez a música:

Ou vai aqui.

E aqui vai mais um recadinho:

${ }^{21}$ Postagem: Quinta-feira, 1 de março de 2012. 


\section{"Que a tua religião, a tua espiritualidade, seja sinônimo de liberdade e não de culpa.}

Que a tua fé seja algo encantador, que te impulsione nẫo apenas para frente, mas para o respeito de tudo o te faz ser quem vocé é.

Deus, o teu Deus,

deve ser a Força que te liberta

e não a que te faz prisioneiro(a) de si."
- Helena Paix

HTTP://SAPATILHANDO.BLOGSPT.COM
Lembrando que

pedimos sempre

para que nos

escrevam com

sugestões, comentários, opiniões... O encontro é NOSSO. Só tem graça assim.

\section{conviteaoracao@gmail.com}

Um bjão!

Postado por Helena às $12: 25$

Deleuze e Guattari (2012) deixam claro que concordam com a escritora Virginia Woolf ao sorrir da interrogação sobre a existência de uma escrita feminina. Não há uma escrita feminina, há a necessidade de a escrita produzir um devirmulher, como átomos que se impregnariam por todo o campo social e deveriam tomar também os homens para um devir.

Partículas muito suaves, mas também duras e obstinadas, irredutíveis e indomáveis. [...] Eles devêm-mulher escrevendo. É que a questão não é, ou não é apenas, a do organismo, da história e do sujeito da enunciação que opõem o masculino e o feminino nas grandes máquinas duais. A questão é primeiro a do corpo - o corpo que nos roubam para fabricar organismos oponíveis (DELEUZE; GUATTARI, 2012, p. 72).

Portanto, a discussão levantada por Helena no blog Sapatilhando não pertence a um sexo em oposição a outro porque as ações, as idades, as ordens sociais pré-determinadas produzem um número infindável de sexos moleculares, conforme afirmam os autores, que se apresentam na linha de fuga que é a escrita de si, o dizer universal do devir-mulher e dessa escrita que atinge a todos é de onde 
vem a força para atravessar os sexos, as idades e para viver os fluxos, partículas , lentidões e velocidades da existência.

Entre 2010 e 2013 temos uma Helena que abre novos caminhos e novas escritas de si, uma Helena que ficcionaliza a sua produção textual e uma Helena orante, a que busca a religião como forma de irmanação e apaziguamento para consigo e para com as lutas nas quais ela se envolve, se identifica e também se frustra.

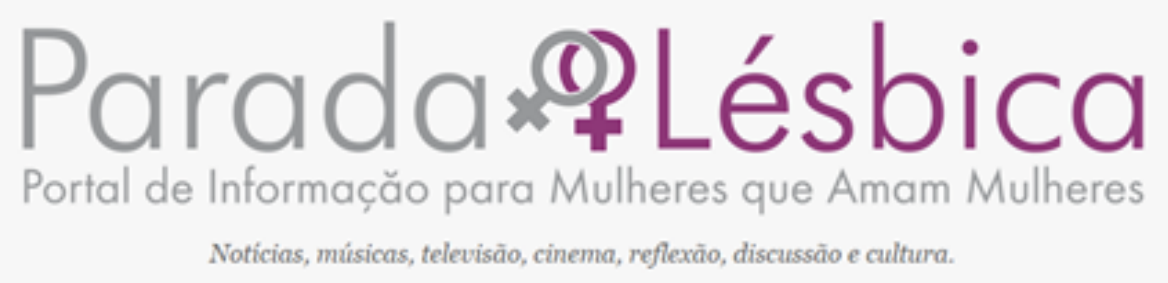

Pais que não aceitam seus filhos(as) homossexuais.

31/05/2012 by mesena Paíx

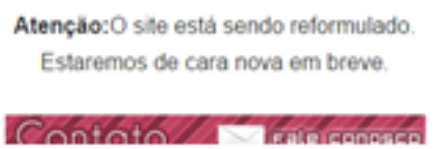

$[\cdots]$

\section{PARA PAIS E FILHAS(OS)}

Se vocês têm questöes religiosas (a maioria dos conflitos em geral nasce disso), por favor vejam o documentário "Como diz a Bíblia", no qual vários mitos a respeito da relação "homossexualidade e religião" são derrubados por líderes religiosos, pesquisadores e intelectuais renomados.

Também estão no documentário vários testemunhos de pais e filhos a respeito da não aceitação. Não há como não se transformar ao ver esses relatos - desde que vocês estejam com o coração aberto ao diálogo, claro.

Fonte: $\underline{\text { http://paradalesbica.com.br/2012/05/31/pais-que-nao-aceitam-seus-filhosas-homossexuais/ }}$

A busca da ficção pela autora do blog aponta para uma certeza pessoana de que quando buscamos a literatura como forma de manifestação é porque a vida não nos basta. Ao longo desse período de produção de postagens, vemos um 
retorno constante à mesma temática da resistência familiar a uma outra identidade que não seja aquela socialmente estabelecida. Helena produz incessantes postagens sobre o assunto, mas desabafa em alguns momentos o quanto esta é uma luta incessante:

\section{-..-> 0 texto finalmente!!!}

Tenho recebido algumas mensagens que me deixaram preocupada.

Algumas queridas que têm se sentido cansadas, sem esperanças, sem sentido de continuar a viver.

Este texto (assim como o áudio do Um Convite à Oração) é para vocês! ;]

\section{Quando nada mais vale à pena}

Existem esses tempos, sabe?

Quando o colorido perde suas cores, quando os sorrisos parecem longínquos, quando a esperança se veste de um cinza desbotado e frágil.

Parece que as forças que você um dia teve já não fazem parte de você.

Parece que o seu caminho criou tantas curvas que você só rodopia, perdida e tonta com tanta confusão.

Parece que crer não é mais possivel, que nada do bom ou do belo ainda existem num mundo tão feio e caótico.

São horas de um buraco negro profundo, onde a vida parece tão dispensável que você pensa sim em soluções mais mórbidas e definitivas.

\section{A necessidade de um recomeço é tão grande que você acha que a solução é criar um fim.}

E a verdade é que é natural passar por isso.

(muita atenção no verbo escolhido!)

A metáfora que eu gosto é a de você caminhando.

Há um longo percurso, sabe?

Você não começou sozinha. Outros te trouxeram até aqui.

Te guiaram pelo caminho.

Mas aí, olha que desgraça, você aprendeu a andar.

Aí, não teve jeito: você teve que continuar sozinha, agüentando a terrível responsabilidade de escolher as viradas e paradas do teu caminhar.

Acontece que a pegadinha é que apesar do caminho ser nosso, outras pessoas ficam gritando nas beiradas do caminho: 
"Vira ali!"

"Segue por aquela estrada!"

"Se você me ama e me respeita vai por ali!"

"Se seguir aquela outra você vai se arrepender terrivelmente!"

Coisas nos são gritadas em sons tão estridentes e brutais que nos sentimos assustadas a ponto de ouvi-las ou de não confrontá-las.

E aquele teu caminhar, que deveria ser um movimento contínuo teu, de formação e de essência, de repente se transforma numa pausa.

Entenda: qualquer caminho que não seja o TEU caminho, é uma parada.

E uma parada cansa, extenua, desgasta, não nos deixa ver a paisagem em movimento, não nos permite enxergar o que enxergaríamos se estivéssemos caminhando.

É como Clarice Lispector diz:

"Estou sendo e ao mesmo tempo me fazendo."

E se você está sendo pela voz dos outros, você também está se fazendo em algo que os outros querem.

Ouvir os sons das vozes que gritam significa apenas uma coisa: NÃO OUVIR A TUA VOZ.

A questão do cansaço é que ele não é gratuito: muito aconteceu para que ele chegasse.

E uma vez que esse tipo de cansaço chega, isso significa que você já vem escutando e seguindo outras vozes há muito tempo!

Há tanto tempo que você nem lembra direito aonde parou e para onde ia...

Há tanto tempo que você já não sabe mais qual voz escutar.

Há tanto tempo que tudo se vestiu de uma mesmice aterrorizadora e todos os lados que você olha parecem guardar a mesma mensagem: a de que não há mais caminhos a seguir.

E o que eu quero te pedir agora é algo muito grande e sério: GRITE VOCÊ!

Expulse dos teus pulmões todas as vozes do caminho!

Esvazie-se das noções dos outros!

Liberte-se da descrença e da decepção (que são sentimentos em relação aos outros também)! 
Em uma primeira instância visceral, teu mundo é composto Só POR TI.

Entende?

VOCÊ DEVE SER O CENTRO DO SEU MUNDO.

Só assim é possivel se reorientar.

Encher-se dos sonhos que um dia te habitaram.

Ver, pelos teus olhos, os detalhes do caminho, os pés que andam, o tempo que passa...

Os sorrisos, os teus sorrisos, não se perderam pelo caminho: você apenas não os

pegou.

E não os pegou porque não estava olhando o teu caminho com os teus olhos.

Sorriso é coisa pessoal: só você sabe o formato e a razão do teu.

Então entenda: não é que nada valha mais à pena.

É QUE NÃO VALE MAIS À PENA CONTINUAR CAMINHANDO COMO VOCÊ VEM FAZENDO.

Essa forma de caminhar já se mostrou inútil e cansativa e extenuante.

Sei que você acha que você nasceu uma vez e pronto.

Mas a verdade é que o útero principal é a própria vida: o túnel escuro (onde você está no momento) e que está te empurrando para a decisão de nascer através do choro.

É preciso um retorno: um retorno a você mesma.

Àquilo que você é e àquilo que te faz.

À construção básica de ti: aquilo que te edifica e que te faz perceber que teu caminho continua ali (sempre esteve), esperando que você caminhe por ele.

E isso é tudo o que você precisa fazer: continuar caminhando. Tampe os ouvidos. Tudo o que você precisa escutar é o que te bate no peito. Teus pés reaprenderão a caminhar quando o teu coração finalmente puder falar livremente.

É que o que vale à pena é tão, tão simples: é precisamente você.

Você e o caminho que é verdadeiramente teu.

ps: em decorrência do atraso do "Um Convite à Oração" da semana passada, só postaremos um novo programa na próxima quinta-feira (05/04), está bem? Eu estarei em Fortaleza nesta data, mas deixaremos gravado e o Artur e a Del publicarão aqui. ;]

Bjão, pessoalzinho querido! 
Nesta postagem Helena anuncia a publicação do seu primeiro conto. Um conto que vai ocupar um site feminista que organiza o movimento lésbico no ciberativismo, mas não abre mão da dialogicidade com suas leitoras e pede que elas opinem ao visitar o material:

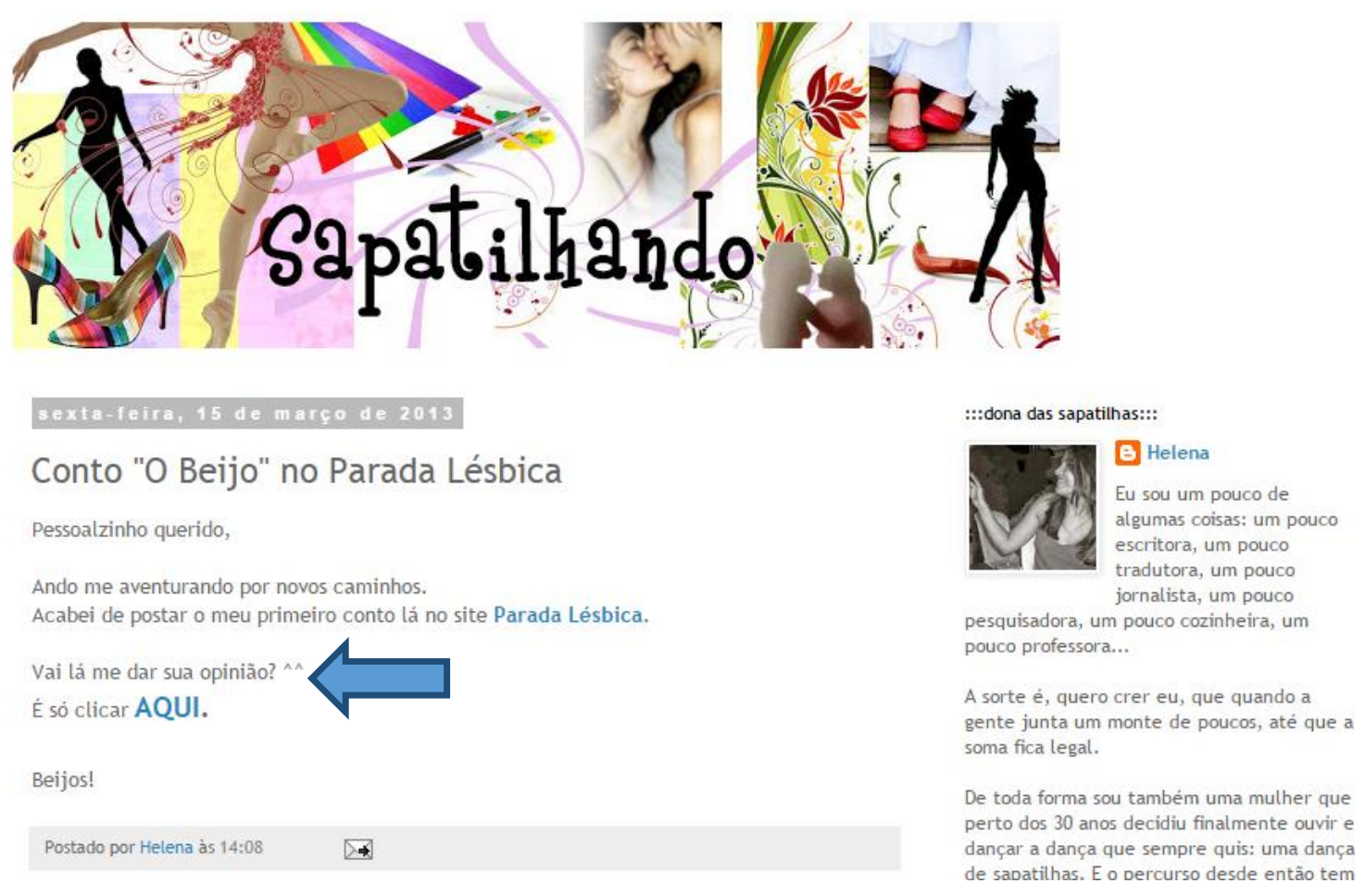

Segundo Guattari (1992), a busca da ficção é uma forma de corporificação da subjetividade. Ao criar outros personagens, o autor se projeta em devires. Na verdade, a subjetividade, segundo o autor nesta obra, é "[...] um estado nascente que não cessaremos de encontrar no sonho, no delírio, na exaltação criadora, no sentimento amoroso [...]" (GUATTARI, 1992, p. 16). Dessa forma, Helena ao ficcionalizar, ao buscar um constante contato com a própria família, com famílias que virtualmente se constituem sua rede de relações no mundo virtual, cria as condições para deixar emergir seu processo de subjetividade, processo assim definido pelo autor da seguinte forma:

[...] a definição provisória, mas englobante que eu proporia da subjetividade é: o conjunto das condições que torna possível que instâncias individuais e/ou coletivas estejam em posição de emergir como território existencial auto referencial, em adjacência ou em relação de delimitação com uma alteridade ela mesma subjetiva. Assim, em certos contextos sociais e semiológicos, a subjetividade se individua: uma pessoa, tida como responsável por si mesma, se posiciona em meio a relações de alteridade regidas por usos familiares, costumes locais, leis jurídicas. Em outras 
condições, a subjetividade se faz coletiva, o que não significa que ela se torne por isso exclusivamente social (GUATTARI, 1992, p. 20).

Como também podemos verificar no pensamento do autor, a ideia de que não podemos, na atualidade, dissociar as teorias do inconsciente das práticas psicanalíticas, psicoterapêuticas, institucionais, literárias, entre outras porque o inconsciente se tornou um "equipamento coletivo" compreendido no sentido mais amplo.

Podemos deduzir portanto, que Helena ao lançar mão de diversas linguagens e assumir diversas mídias, busca abarcar as possibilidades de manifestação do inconsciente. E diante da complexidade desse processo, hoje, segundo Guattari (2000) se faz necessário uma nova modelização da subjetividade, mediante uma cartografia demarcada pelos aspectos cognitivos, míticos, rituais entre outros, a partir da qual, Helena, por exemplo, se posiciona de modo estético quando ficcionalizar, de modo mítico e ritual quando busca no sagrado e religioso, um outra linha de fuga do processo de territorialização no qual está inserida.

As condições de produção evocadas nesse esboço de redefinição implicam, então, conjuntamente, instâncias humanas inter-subjetivas manifestadas pela linguagem e instâncias inter-subjetivas manifestadas pela linguagem e instâncias sugestivas ou identificatórias concernentes à etologia, interações institucionais de diferentes naturezas, dispositivos maquínicos, tais com aqueles que recorrem ao trabalho com computador, Universos de referências incorporais, tais como aqueles relativos à música, artes plásticas. Essa parte não-humana pré-pessoal da subjetividade é essencial, já que a partir dela que pode se desenvolver sua heterogênese (GUATTARI, 1992, p. 20).

Vemos que Helena, portanto, ao buscar a ficção e a oração, ela usa a função poética "[...] para recompor universos de subjetivação artificialmente rarefeitos e singularizados [...]", gerando, como explica o autor, catalizadores existenciais que lhe deem consistência, ao que está diante de si: ela mesma.

Desse modo, temos claro que o modo de produção de subjetividade no blog Sapatilhando é polifônico. Guattari e Bakhtin aqui conversam e aproximam conceitos, como o primeiro deixa patente na obra Caosmose (1992) ao discorrer sobre o ritornelo e a polifonia. Para tornar claro esta complexidade, o autor fala que o ritornelo ou o refrão, marca o ritmo nos territórios da subjetividade. Várias linguagens retomam sempre em uma polifonia de vozes temas que vem e vão ao longo das postagens do blog. A família, por exemplo, é um refrão constante, o amor 
entre iguais também é discutido em diversos momentos e tons diferentes. E o refrão constante ao longo de Sapatilhando sempre é a necessidade de auto-aceitação, de conquistar-se o direito de ser quem se é. São novos territórios que vão sendo marcados e novas linhas de fuga que se espraiam.

\begin{abstract}
Para ilustrar esse modo de produção de subjetividade polifônica em que um ritornelo complexo representa um papel preponderante, consideremos o exemplo da consumação televisiva. Quando olho para o aparelho de televisão, existo no cruzamento: 1 . De uma fascinação perceptiva pelo foco luminoso do aparelho que confina ao hipnotismo; 2. De uma relação de captura com o conteúdo narrativo da emissão, associada a uma vigilância lateral acerca dos acontecimentos circundantes (a água que ferve no fogo, um grito de criança, o telefone...); 3 . De um mundo de fantasmas que habitam meu devaneio... meu sentimento de identidade é assim assediado por diferentes direções. O que faz com que, apesar da diversidade dos componentes de subjetivação que me atravessam, eu conserve um sentimento relativo de unicidade? Isso se deve a essa ritornelização que me fixa diante da tela, constituída, assim, como nó existencial projetivo. Sou o que está diante de mim. [...] Como Bakhtin, diria que o ritornelo não se apoia nos elementos de formas, de matéria, de significação comum, mas no destaque de um motivo ou leitmotiv existencial se instaurando como atrator no seio do caos sensível e significacional (GUATTARI, 1992, p.28-29).
\end{abstract}

Segundo o mesmo autor, os dispositivos de produção de subjetividade podem existir em escala de megalópoles como em escala dos jogos de linguagem de um indivíduo, de modo microfísico, seja em uma atividade política, quando se instalam dispositivos que podem mudar a vida de alguém em particular ou de um grupo. Assim, podemos afirmar que Sapatilhando é um dispositivo de produção de subjetividade, quando suas postagens geram reação em quem escreve e em quem lê, além de disparar uma ação rizomática em rede no mundo virtual que resultou na criação de grupos de apoio a mulheres lésbicas, a grupo de pais de homossexuais, a convites para palestras sobre a temática de identidade de gênero para autora, de rodas de conversa provocadas por estas palestras.

\title{
PARA PAIS QUE NÃO ACEITAM A HOMOSSEXUALIDADE DE SEUS FILHOS
}

Sei que é difícil.

Que no momento que você soube da sua filha ou do seu filho o peso do mundo caiu sobre você.

Mas saiba que esse é o mesmo peso que a(o) sua(seu) filha(o) carrega todos os dias.

\section{Não se sinta julgado por não aceitar. A maioria dos pais - inclusive os que hoje aceitam - um dia sentiu tudo o que você está sentindo neste momento.}


Apenas, agora que você sabe, é hora de buscar mais do que nunca, o diálogo.

Muitos pais se distanciam dos seus filhos por conta dos vários conflitos, palavras cruéis trocadas e diferenças de entendimentos acerca da vida.

\section{É necessário que vocês se esforcem, que lutem pelo amor de vocês, pela união do seu núcleo familiar.}

Se você me permitir, gostaria de conversar um pouco mais no vídeo abaixo:

Uma ótima dica tanto para as filhas, como para os pais e mães que têm dificuldades de aceitar a homossexualidade de suas filhas, é o documentário "O Segredo dos Lírios":

OBS: Para os que acompanham o Podcast "Um Convite à Oração", já já estaremos de volta! ;] Obrigada pelas várias mensagens, emails e recadinhos de incentivo!

Eu e o Artur lemos todos e ficamos super felizes com a companhia de vocês!

Até já já! :]

JPostado por Helena às 18:01 13 comentários: Links para esta postagem $\Rightarrow$

segunda-feira, 7 de maio de 2012

De 2012 a 2014, o diário eletrônico vai para além dos textos narrativos escritos e chega aos áudios, algumas vezes de caráter religioso, os vídeos caseiros autorais e vídeos profissionais, quadrinhos de cartunistas que dialogam com as temáticas discutidas e obras literárias que são comentadas, postadas, criando uma cartografia antropofágica com o mundo que cerca a autora, sugerindo ao leitor novas cartas de navegação.

\section{quinta-feira, 15 de março de 2012}

\#6 - Podcast - Mágoas, frustrações, ressentimentos.

Hoje eu e o Artur estamos de volta com nosso encontro semanal do "Um Convite à Oração" com o tema Mágoas, frustrações e ressentimentos.

Sabe aquela dor tão grande que ainda está dentro de você?

Sabe aquelas palavras que the falaram e lhe feriram tanto! 


\section{terça-feira, 11 de fevereiro de 2014}

\section{O meu desejo para ti}

É necessário encantar-se. Por toda uma vida. Por todas as vidas que cabem dentro da vida. Por todas as lágrimas que nos lapidam. Por todos os sorrisos que nos inspiram. Por todos os aprendizados que nos formam.

Há que não amargurar-se: tarefa mais árdua que há! Já que às vezes só amarguras recebemos; mas ainda assim há que olhar para frente, seguir o passo, lutar para transformar o incômodo em mudança.

E quando não der, quando a mudança for inoperável, mudar a nós mesmos, como matéria ímpar que somos, como ponto de nossa própria vista, como fato de nossa própria vida, como fala de nossa própria voz.

Há que crer: se não nos outros, em si mesmo, em si mesma. Não se sai ileso da vida. É impossivel fazê-lo: pois somos nós mesmos criatura que se cria e desfaz-se, somos nós mesmos cirandas de um carrossel que não apenas gira, mas rodopia nossas noções, nossas (in)certezas, nossos referenciais.

Todos esses movimentos de Helena é a autora dando rodopios sobre suas sapatilhas, ousando novos passos, novos dizeres de si e criando linhas de ruptura que se intensificam e constroem novos platôs e novas formas de figurar e reterritorializar seu ser colorido.

\subsubsection{Três platôs - três idades - o percurso da borboleta}

Segundo Deleuze e Guattari (1996; 2012), o conjunto de afetos que preenche os corpos a cada momento é que define sua latitude. $O$ que geograficamente nos define sobre a Terra em relação ao eixo Norte e Sul. Então, somos quem somos dependendo do grau de afetos que nos invade e que nos faz corpos vibráteis.

Os platôs para os autores são as regiões de intensidade contínua dos afetos que se constituem das latitudes dos corpos que encontramos; os corpos podem ser corpos humanos, animais, sonoros, ideias, línguas ou uma ou várias coletividades. 
Deste ponto de vista, o blog Sapatilhando como um corpo vibrátil(ideia) e também maquínico, porque em certa medida agencia, é uma criação autoral que é produto de uma afetação da autora diante do real que a constitui, também afetou outros corpos que tiveram contato com essa escrita. Escrita que se manifestou em várias linguagens e juntos estes corpos alcançaram diversos platôs, cada um com sua intensidade a partir da sua latitude.

Sapatilhando também foi afetado pelas latitudes dos corpos vibráteis que constituem os leitores do blog, portanto uma coletividade interpretante que se deixa afetar pelo signo que é o blog. Mas que também nessa relação produz novos signos quando constroem blogs a partir da leitura deste. Uma cadeia de afetações rizomáticas sem fim.

Se pensamos em Sapatilhando na perspectiva dos platôs, vislumbramos um primeiro platô se constituindo quando da disposição da autora em se mostrar, em usar da escrita para manifestar-se, dizer de si para outrem. É um movimento inicial de demonstrar estar sendo afetada pela voz interior que a apavora. A larva da futura borboleta ganhando tônus e viço.

Sapatilhando, o blog, é em si um signo na perspectiva peirceana conforme defende Santaella (2007a), enquanto imagem que se apresenta na tela quando acessamos o seu endereço virtual e quando representa o sentir de alguém, portanto, um si-signo e quando relata um processo de mudança apresenta sua característica de quali-signo e ao tratar as temáticas que afetam diversos outros corpos maquínicos e desejantes na perspectiva de Guattari (1988), adquire sua característica de legi-signo. 


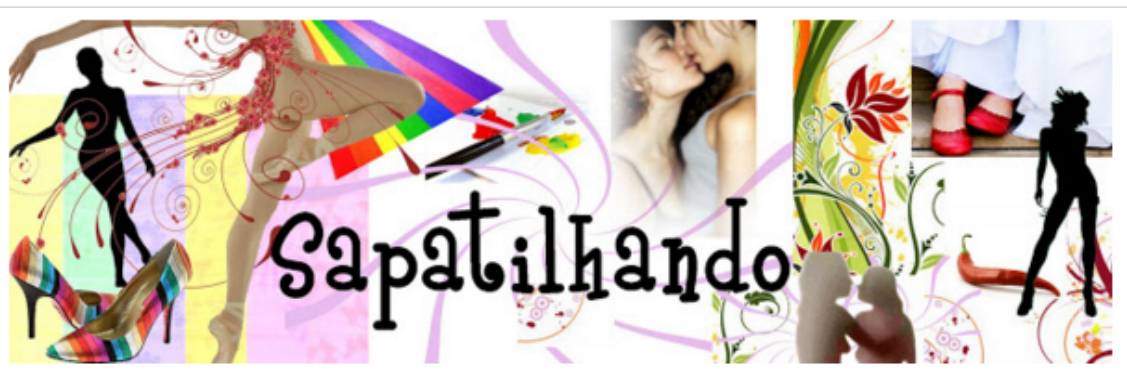

segunda-feira, 24 de marģo de 2014

Não me fale de você

"O que gosto em vocês duas é que vocês são discretas".

"Já vou avisando que NUNCA quero ver ela aqui em casa!".

"Não tenho nada contra, mas não quero ver homem beijando

homem não".

"Minha filha, quero saber do seu emprego, dos seus estudos, mas não quero saber da sua vida não".

"Desde que eu não saiba de nada, tudo bem."

Existem várias maneiras de se negar amor a uma pessoa. Mas tenho descoberto que uma das maneiras mais cruéis de fazer isso é "disfarçar" esse não-amor, de amor.

É enfeitar a não aceitação de "aceitação".

É fazer-se de nobre quando não há, de fato, nada de honrado em tal agir.

Existe uma problemática na palavra TOLERÂNCIA.

Ela é sinônima de suportar. De aceitar com indulgência: ou seja, é tachar de errado aquilo, mas em nome de uma "bondade extrema", suportar.

:::dona das sapatilhas::

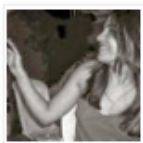

B Helena

Eu sou um pouco de algumas coisas: um pouco escritora, um pouco tradutora, um pouco jornalista, um pouco pesquisadora, um pouco cozinheira, um pouco professora...

A sorte é, quero crer eu, que quando a gente junta um monte de poucos, até que a soma fica legal.

De toda forma sou também uma mulher que perto dos 30 anos decidiu finalmente ouvir $e$ dançar a dança que sempre quis: uma dança de sapatilhas. E o percurso desde então tem sido cheio de beleza e aprendizados! Deixo aqui os pensamentos, dúvidas, certezas, sorrisos e lágrimas desse caminho de descobertas e desafios.

Sobre a vida em geral, acredito que sempre imprimimos um pouco de quem somos em tudo o que fazemos, e realmente acho que estamos aqui para deixar que o tempo nos

Não querer saber é isso: é não querer.

É não desejar o conhecimento. É não querer o envolvimento.

E como amar alguém sem envolver-se?

:: Sobre Homossexualidade e Religião :.:

http://www.rea.pt/religiao.html

Como se fragmenta uma pessoa e exige aceitar apenas pedaços dela?

Eu proponho relacionamentos reais: eu proponho só ter em minha vida íntima aqueles que me sejam íntimos.

Não quero encenações.

Não quero "fazer de conta". Quero o que é real.

Quero pessoas que, de coração, falem: QUERO SABER DE VOCÊ!

E se o real é a vontade de não saber: que não se saiba.

Que a distância de fato se faça e que somente deixemos em nossas vidas aqueles que nos querem como somos.

Você pode achar que dá para conciliar apenas metade de você mesma(a) com aqueles que só querem isso: mas a vida lhe mostrará que não dá.

À medida que você for ficando mais velho(a), seu tempo vai ficando mais precioso. E passar tempo com alguém deve ser um ato voluntário e desejado: não uma obrigação.

Quando o Natal chegar, você vai querer estar com quem esteve com você 0 ano todo. Quando os aniversários chegarem você só quererá que lhe cante "Parabéns" quem de fato Ihe parabeniza sempre por você ser quem você é.

Quando os filhos(as) vierem você só vai querer estar perto de quem ame a sua família no formato exato dela: sem vergonha, sem culpa, sem apontar dedos e temer o inferno.

Aceitar é aprovação, é concordância.

Não existe aceitação pela metade.

Não existe a infame frase: "Aceito, mas não concordo".

Não quando estamos falando de vida, de sentimentos, de famílias.

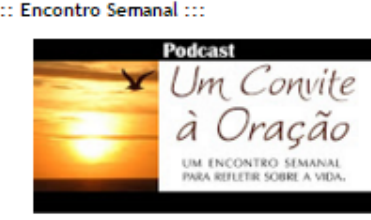

:: Brochura sobre Homossexualidade :::

SERMOS NÓS PRÓPRIQS

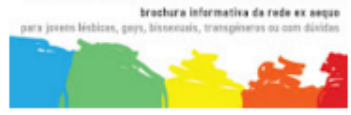

Helena Paix @helenapaix

Nem todo dia se tem forças para sonhar. Nesses dias, descanse $e$ permita-se chorar. Depois, vistase de sua teimosia: e sonhe novamente.

1:19 AM - 10 Mar 2013

a $277 \bullet 4$ 
Copiamos para o nosso texto imagens estáticas de um hipertexto que é movimento e não se deixa capturar. Desta forma aqui temos também a Primeiridade, na perspectiva da Semiótica, quando a autora se mostra disponível para construir o cenário no qual vai se desenrolar a cena do seu mostrar-se para o outro. Quando também, nós leitores, em uma primeira aproximação somos afetados pelas cores, formas, linhas, luzes, complementos e contrastes do blog enquanto ferramenta virtual de inúmeras possibilidades de leitura. No primeiro momento estamos nós e a autora diante do campo do sensível, do Mapa sensorial que se desenha.

Quando observamos as imagens que integram o Menu lateral do blog, temos a clara noção dessa fase inicial de construção que vai permanecer ao longo de toda a existência das postagens escritas.

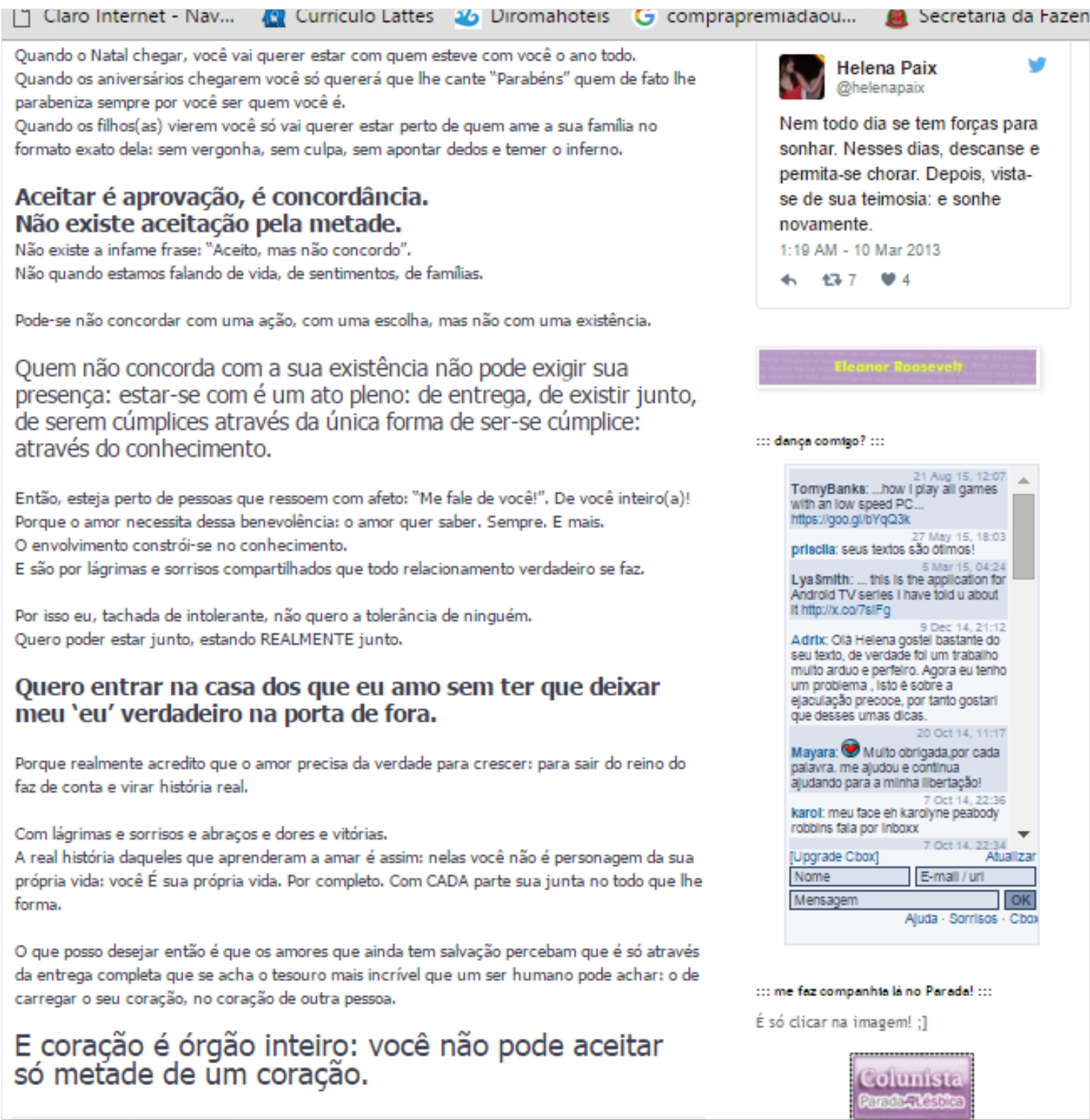


Podemos olhar a tela do Sapatilhando, como se olhássemos para uma pintura, com suas cores que saltam aos olhos, cores em detalhe, porque tudo se apresenta como uma imensidão branca, na qual dançam letras cinzas e azuis, letras de diferentes tamanhos, que podem ser assim por uma questão de instabilidade do software do blog ou porque a autora varia de acordo o tom da sua voz.

O primeiro foco de nossa atenção, enquanto leitor se volta para o centro alto da página online. O banner lá está, como um pachtwork de imagens, formas e cores.

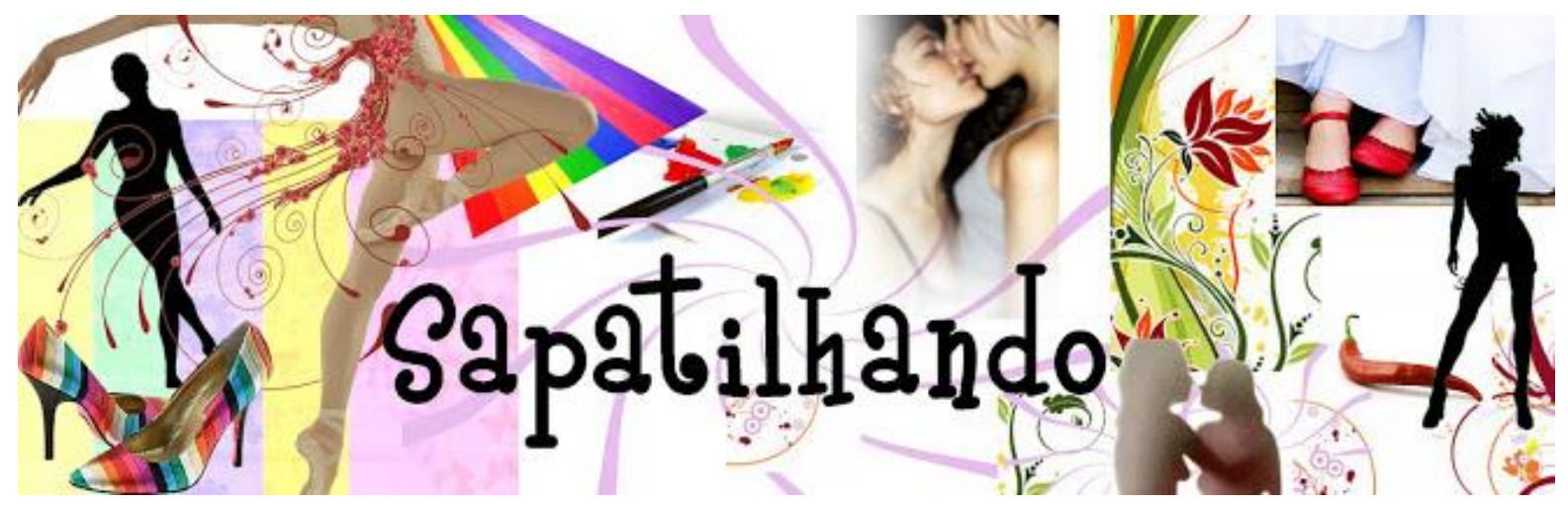

No conjunto o banner dá a ideia de movimento. Há pernas femininas sombreadas, ensaindo passos de dança, seja nas pontas, seja nos saltos, nas pontas das sapatilhas ou em sapatinhos boneca. Sapatos, pernas e movimento indiciando que as mulheres se movem, processam, experimentam e vivenciam.

Todas as figuras femininas presentes no banner são longuilíneas, pernas que se misturam com os arabescos lilases, florais e arco-iris, elementos que abusam do simbolismo feminino-feminista e também da luta dos movimentos que discutem gênero.

No banner de abertura a marca do feminino é muito forte, inclusive porque há vultos de mulheres, imagens de mulheres que se acariciam, se beijam. E desse conjunto surgem pincéis que distribuem pingos de tinta do arco-iris por toda a extensão dessa imagem de recortes.

A tela online não usa das noções de perspectiva e profundidade, deixando o todo do banner envolto em uma atmosfera de leveza e sonho, uma 
esconder-se e mostrar-se como de fato ocorre no processo de subjetivação que vai se discorrer ao longo das postagens do blog.

O banner é a porta de entrada do universo Sapatilhando, o frontispício de um portal. Somado a ele temos a coluna lateral, o menu lateral direito que ancora uma série de imagens fixas e ícones de acesso que constroem ou são links pelos quais a borboleta, a guerreira Helena Paix (a guerreira da paz), exercita sua comunicação com outras instituições e se debruça para realizar a escuta online dos seus leitores.

No início da coluna está uma foto de um busto lateralizado de Helena Paix, uma foto que mostra uma mulher, que pode ser qualquer mulher de cabelos longos, porque pouco nos oferece dos detalhes da face. Na foto está o título "a dona das sapatilhas".

:::dona das sapatilhas:::

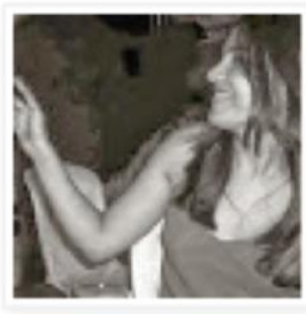

Q Helena

Eu sou um pouco de algumas coisas: um pouco

escritora, um pouco

tradutora, um pouco

jornalista, um pouco

pesquisadora, um pouco cozinheira, um

pouco professora...

Em seguida, este menu oferece um banner pequeno em forma de convite para momentos de oração semanal.

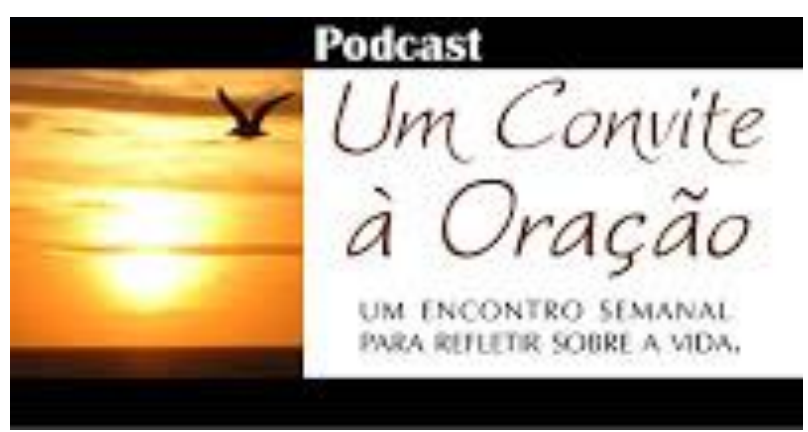


A marca do terceiro platô está aí inserida, mas não temos noção de quando ocorreu sua introdução porque a página, na visão do leitor, não nos permite saber a data da inserção desse ícone. Aí também se configura a Secundidade, quando a autora indica as portas de saída e entrada de novos territórios e constrói o Mapa relacional no qual o blog se constitui como rizoma e se insere na blogosfera, no ciberespaço e no mundo real ao se relacionar inclusive com outros campos do conhecimento humano. A intertextualidade se fazendo, o hipertexto exercendo suas potencialidades.

Vislumbramos uma série de banners/links de redes sociais como site, Facebook e Twitter que indica ao leitor que a guerreira está presente também em outros ambientes do mundo virtual. Com qual face? Com qual avatar? Sempre Helena.

::: me faz companhia lá no Parada! :::

É só clicar na imagem! ;]

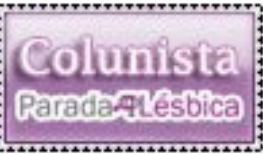

:::pra conversar::

- email(prefiro!): helenapaix@gmail.com

- MSN: adoradomar@hotmail.com

::: Me adiciona lá no Face! ::: facebook

:::iorgut dançarino:::

- Helena-Cantarolando-Assobios

::: Pois então....Aderi à moda! Agora tenho twitter!! ::: 


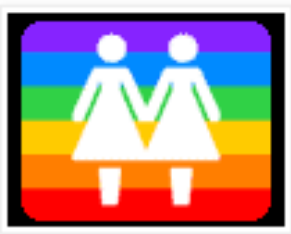

Em seguida a esses links, a autora posta de maneira fixa imagens com características de cartão-postal, de selo, de marca para assinalar a questão homoafetiva, ícone de casais de mulheres, uma trilogia de fotos que traça uma comparação entre as formas de expressão da afetividade humana: homem/mulher, homem/homem e mulher/mulher e entre elas alterna frases que indicam a igualdade entre as três situações.

\section{Para mim, isso:}

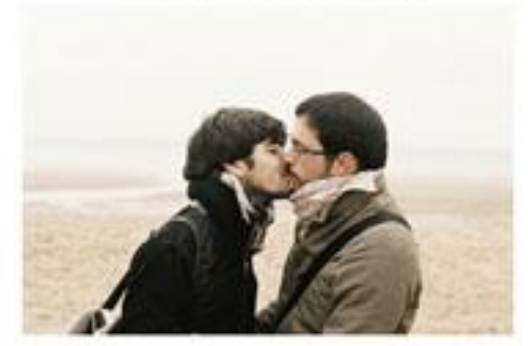

$$
\text { e tão fofo quanto isso: }
$$

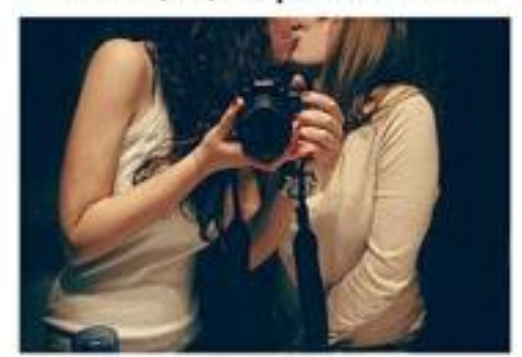

$e$ isso:

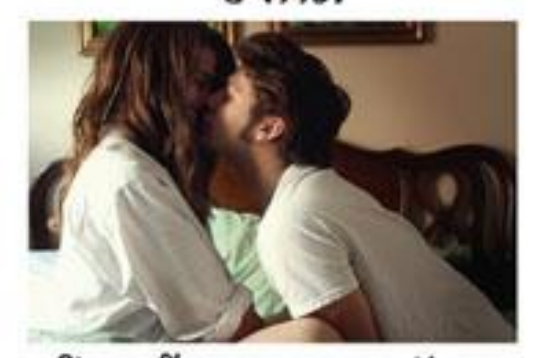

$$
\begin{aligned}
& \text { Oiga não ao preconceito. } \\
& \text { Oiga Sim ao amor. }
\end{aligned}
$$

Há links de livros online que tratam da discussão da homoafetividade. 


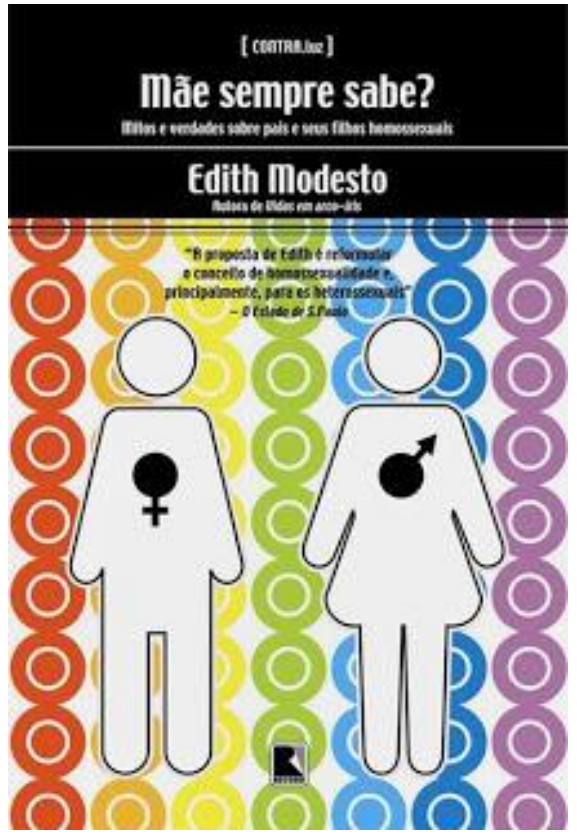

Há links de blogs que são indicados como parceiros de caminhada e processo, há indicações de leituras de escritores com os quais a autora do blog dialoga, há gravações de áudio e vídeos nos quais a autora se pronuncia e leva os leitores a visitarem canais de rádio e de internet, como o youtube.

Poucos vivem para aprender a ser quem deveriam.

Muitos vivem para ser aquilo que thes queriam.

Há que encantar-se por seus próprios olhos.

Só assim nasce-se para si mesmo.

E pode-se, então, crescer.

Postado por Helena às 22:58 Um comentário: Links para esta postagem

\section{domingo, 15 de setembrode 2013}

\section{Grávida de si mesma}

Somos feitas de dilemas. Somos várias perguntas. Somos algumas respostas. Somos ansiedade e medo. Somos muita busca, muita procura, muito desejo de soluções.

Mas as soluções não são mágicas. Nunca são.

Podemos pedir opiniões, podemos até escutar essas opiniões, podemos pedir que outros decidam por nós, mas a grande e cruel verdade é que no fim a ação da escolha é sua e de mais ninguém.

Se você enfrentou ou não o que deveria ser enfrentado. Se foi desta vez ou não. Se a tua vida está sendo de fato tua. Se teus passos estão sendo de fato teus. Se a voz que te bate no peito está sendo verdadeiramente ouvida ou não.
BLOCAR SÓ SE FOR COM LIBERDADE!

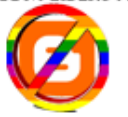

::pra sapatilhar::

- Calcinhas no Box

- Concertina

- Contra o Coro dos Contentes

- Coração Vulgar

- Delirium

- Dra. Gô

- Ela é meu pecado

- Elas e Elas Filmes

- Fancha Laranja

- Fazendo Manha

- Flôr de Azeviche

- Incompletudes

- Longe do Armário

- Lésbica Simples

- Manual d@ Cafajeste

- Meninas Super Sapatosas

- Mãe, eu sou lésbica

- Na Ponta dos Dedos

- Nascidos do Mar

- Não memórias de uma lésbica

- Petit Subervision 
Há o mundo dos quadrinhos que é trazido em tirinhas de cartunistas reconhecidos e personagens que tem relação direta com a questão da identidade humana, do ser e estar no mundo.

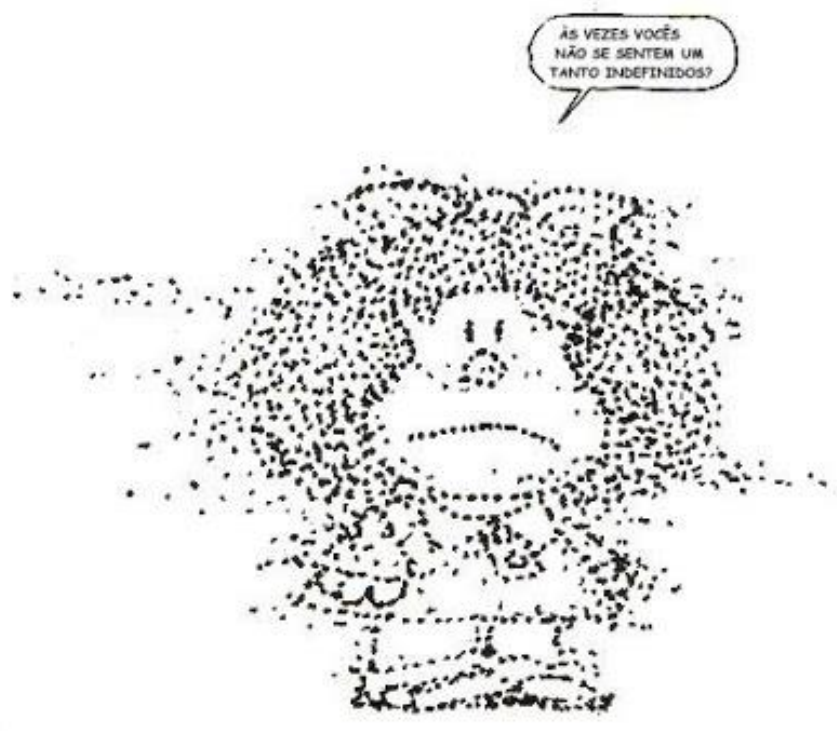

Constatamos dessa maneira que o blog Sapatilhando é um hipertexto na sua espacialidade topográfica quando se caracteriza como um espaço de escrita e leitura não hierárquico que não apresenta um centro regulador.

Sapatilhando na sua multisemiose possibilita a absorção de diferentes aportes sígnicos e sensoriais em uma mesma superfície de leitura, são palavras, sons e seus efeitos e imagens diagramáticas.

Além de propiciar a interatividade entre múltiplos autores em superposição e em tempo real, em função da sua natureza polifônica e intertextual. Helena a autora do blog, escreve, Helena lê, Helena é lida, Helena sugere autores, cita autores e obras e Helena aponta outros links e blogs e sites em uma cadeia sem fim.

Sapatilhando como hipertexto atende ao princípio da metamorfose apontado por Lévy (1993) quando encontra-se em constante construção e renegociação. Sua extensão, composição e desenho sempre em mutação, conforme a interação dos atores envolvidos. Um verdadeiro trabalho coletivo. 
Um trabalho coletivo fractal no qual qualquer nó ou conexão, quando acessado pode dar a chave para uma ou várias redes de nós e conexões de modo infinito.

Como hipertexto, Sapatilhando não apresenta uma unidade orgânica, nem um motor interno, tudo depende de um exterior indeterminado como bem aponta Lévy (1993). O blog cresce ou diminui, se compõe ou recompõe com a adição de novos elementos e conexões com outras redes. E estas redes por sua vez, não estão no espaço, elas são o espaço como define o autor.

O segundo platô se delineia quando Sapatilhando depois do primeiro ano de existência passa a explorar mais sua face militante, uma Helena que se identifica com a guerreira, com a mulher dona de si que se sente forte para dizer às outras que não desistam. A autora se revigora na coragem de exteriorizar seus afetos, quando se sente à vontade para dialogar com suas leitoras e trocar com elas, cada vez mais sua intimidade e seus medos. Só sorri na cara do medo quem já convive com ele.

Em 2009 e 2010 nos deparamos com elementos da Terceiridade com postagens nas quais a autora ousa falar por si própria, opinar sobre várias temáticas, fazer política a favor de minorias, falar enquanto lésbica, usando o eu como pessoa do discurso que se propaga não apenas no espaço virtual, mas que já ganha os encontros de mulheres, os ciclos de palestras, rodas de conversa e outros espaços, nos quais Helena Paix assume ser uma guerreira que fala de si para fortalecer outras vozes na busca de sua subjetivação. Com esses movimentos de expansão de sua autora, Sapatilhando constrói o Mapa Interpretativo, permite abertamente ser visto, ouvido e materializado, abrindo-se como obra coletiva. 


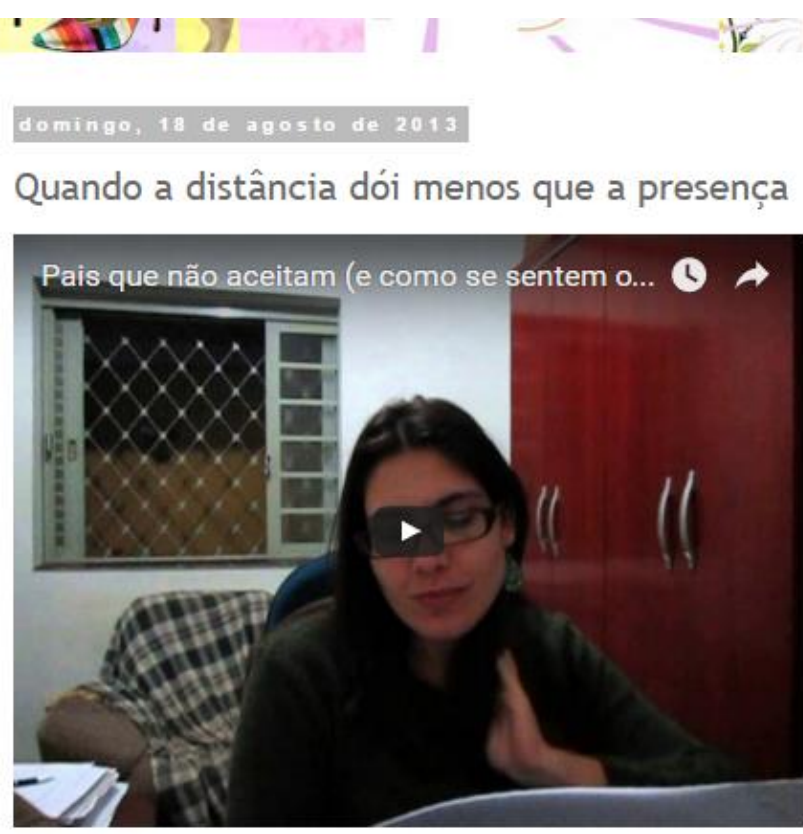

IEXTO:

Eu sei que preciso escrever sobre isso. Sei que a única maneira de transformar tudo o que estou sentindo em algo bom, será conseguir tirar algum sentido, alguma lição, alguma coisa boa de tudo isso.

Sei tambèm que são muitos os que precisam escutar algo, um cafuné que seja, uma luz no fim do túnel tão longo e solitário no qual se encontram.

Mas como tirar sentido do fato de pais não aceitarem seus filhos? :-dona das sapatilhas::

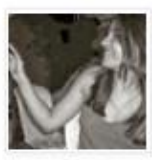

B Helena

Eu sou um pouco de algumas coisas: um pouco escritora, um pouco tradutora, um pouco jornalista, um pouco pesquisadora, um pouco cozinheira, um pouco professora...

A sorte é, quero crer eu, que quando a gente junta um monte de poucos, até que a soma fica legal.

De toda forma sou também uma muther que perto dos 30 anos decidiu finalmente ouvir e dançar a dança que sempre quis: uma dança de sapatithas. E o percurso desde então tem sido cheio de beleza e aprendizados! Deixo aqui os pensamentos, dúvidas, certezas, sorrisos e lágrimas desse caminho de descobertas e desafios.

Sobre a vida em geral, acredito que sempre imprimimos um pouco de quem somos em tudo o que fazemos, e realmente acho que estamos aqui para deixar que o tempo nos melhore: para deixar que ele nos mude por dentro como inevitavelmente nos transformará por fora.

II Queridas mutheres-sapatithas: vamos dar a mão e dançar juntas? :] Sejam todas bemvindas!

Visualizar meu perfil completo

O terceiro platô não menos intenso, mas constituído de modo diferenciado, anuncia quando a autora, nas postagens de 2011 a 2014 muda o eixo da sua latitude para duas direções, uma Helena que abre espaço para seus leitores também escreverem e os incentiva a publicar e com isso dá origem a um blog coletivo, onde há autoras e não mais Helena. $\mathrm{E}$ a outro caminho se delineia quando ela toma para si o trabalho com os pais de filhos homossexuais e com eles atua em uma militância de apoio a outros jovens que se descobrem e sofrem com isso. 
terga-feira, 22 de novembro de 2011

Homossexualidade e Auto-estima

Enfim, de volta!

E com conversa 'ao vivo' :)

Há muito tempo tenho esse projeto em mente, com o intuito de sairmos do impessoal e realmente podermos conversar "cara a cara". Uma coisa ou outra sempre me faziam adiar o projeto, mas agora é tempo de colocar tudo o que eu puder em prática!

Então... bem-vindas(os) ao primeiro VLog do Sapatilhando/Parada Lésbica!! Prazer, Helena Paix! :]

» A temática do vídeo é uma que é, ao meu ver, de extrema importância para a nossa vivência enquanto homossexuais: Homossexualidade e Auto-Estima.

E aí, topa conversarmos um pouco sobre isso?

Então vamos lá!

É só clicar no vídeo!

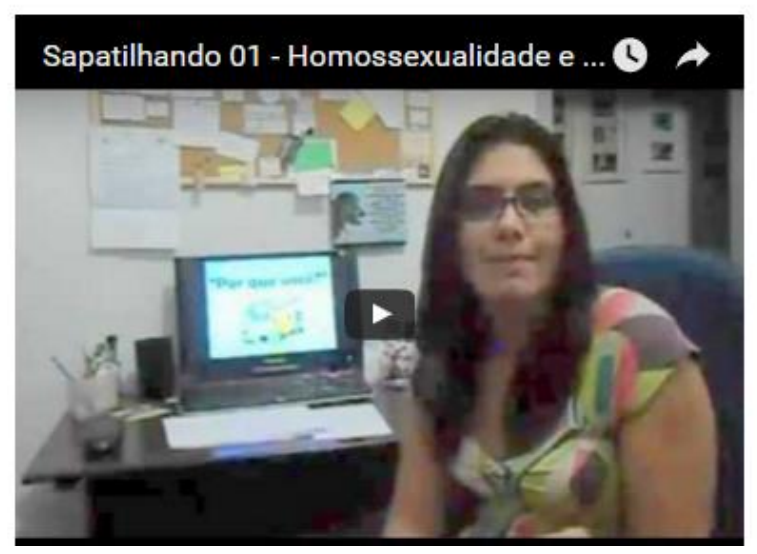

::-dona das sapatilhas:::

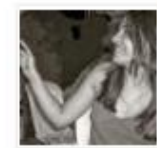

B Helena

Eu sou um pouco de algumas coisas: um pouco escritora, um pouco tradutora, um pouco jornalista, um pouco pesquisadora, um pouco cozinheira, um pouco professora...

A sorte é, quero crer eu, que quando a gente junta um monte de poucos, até que a soma fica legal.

De toda forma sou também uma mulher que perto dos 30 anos decidiu finalmente ouvir e dançar a dança que sempre quis: uma dança de sapatilhas. E o percurso desde então tem sido cheio de beleza e aprendizados! Deixo aqui os pensamentos, dúvidas, certezas, sorrisos e lágrimas desse caminho de descobertas e desafios.

Sobre a vida em geral, acredito que sempre imprimimos um pouco de quem somos em tudo o que fazemos, e realmente acho que estamos aqui para deixar que o tempo nos methore: para deixar que ele nos mude por dentro como inevitavelmente nos transformará por fora.

II Queridas mulheres-sapatithas: vamos dar a mão e dançar juntas? :] Sejam todas bemvindas!

Visualizar meu perfil completo

Nesse platô, a autora pede licença aos leitores de Sapatilhando para orar. Sim, orar e utilizar do áudio para fazer isso. Ela produz uma série de gravações, diria radiofônicas, nas quais ora pela dor que o processo de subjetivação produz.

Nesse platô, a intensidade dos afetos se torna tão marcante que a borboleta rompe o casulo e deixa a postura de uma voz falando e se espelhando em outras vocês, quando afirmava que "eu sou você, por isso sei o que está sentindo agora" para uma Helena que se permite sair do virtual, em um voar com rota definida, com casa, mas que se permite deixar de postar, o que faz em 2014 com apenas duas postagens, e continua seu percurso de outra forma, em outras redes e outros rizomas. O blog foi encerrado? Não, creio que não, apenas corre em outra direção.

Em contato com Helena por email e acompanhando-a no Facebook, soube da oficialização da sua união com sua companheira e a adoção por elas de 
duas meninas. O que vem a partir disso? Vida, mapas, linhas e territórios, no fluxo ininterrupto dos devires.

Desde o seu processo de transformação há uma marca constante nas postagens realizadas. Existe a coluna à direita da tela na qual imagens são repetidas e recorrentes. Espaços que delimitam também o conteúdo ideológico da autora e suas frentes de luta com o mundo que a cerca e suas lutas interiores.

Os platôs e os mapas encontrados pelo cartógrafo, percebidos e sentidos trazem em si as suas próprias buscas, suas leituras de mundo. Tendo como norte o princípio da cartografia, Sapatilhando permite entradas múltiplas, porque pode ser acessado de diversos pontos, podendo também remeter a quaisquer outros pontos do seu território. O rizoma, na perspectiva deleuziana, possui sempre regiões insuspeitas, que se pauta por uma lógica do devir, da exploração e da descoberta de novas facetas.

Segundo Santaella (2001), sem dúvida a hipermídia, a exemplo do blog Sapatilhando, não é apenas um novo meio de transmissão de conteúdos, é muito mais complexo que isso, é uma linguagem em busca de si mesma.

Essa busca depende, segundo a autora, de hiper-sintaxes que consigam dar novas funções às linguagens criando uma nova trama multidimensional:

Brotando da convergência fenomenológica de todas as linguagens, a hipermídia significa uma síntese inaudita das matrizes da linguagem e pensamento sonoro, visual e verbal com todos os seus desdobramentos e misturas possíveis [...]. Ao escolher um percurso, entre muitas possibilidades, o leitor estabelece sua coparticipação na produção das mensagens. (SANTAELLA, 2001, p.392)

As tramas construídas com esses diversos recursos concretizam as revoluções sapatilhas de Helena, lança-a para outros espaços e com ela vão também suas leitoras, em um mapeamento pessoal, cada uma traçando seu percurso no hipertexto Sapatilhando.

\subsubsection{Das linhas e das revoluções}

Deleuze e Guattari (2010) entendem a concepção de sujeito e de subjetividade como processos inacabados, dando relevância ao conceito de desejo, 
dando-Ihe um estatuto diferente daquele que é apresentado na abordagem psicanalítica freudiana. Para ambos o desejo não significa falta ou carência, porque a ele nada falta, ele é excesso, transbordamento e sempre está buscando novas conexões.

Nesses processos inacabados estão em constante tensão a linhas molar e a linha molecular que constituem a paisagem subjetiva, a primeira expressando os grandes agenciamentos sociais e a segunda compreendendo as formações íntimas desterritorializantes:

Toda sociedade, mas também todo indivíduo, são, pois, atravessados pelas duas segmentaridades ao mesmo tempo: uma molar e outra molecular. [...] se são inseparáveis, é porque coexistem, passam uma para a outra, segundo diferentes figuras como nos primitivos ou em nós - mas sempre uma pressupondo a outra. Em suma, tudo é político, mas toda política é ao mesmo tempo macropolítica e micropolítica (DELEUZE; GUATTARI, 1996, p.90).

Os movimentos sociais, assim como as instituições são atravessadas por forças de produção e reprodução, moleculares e molares. Neles, travam-se lutas permanentes entre os processos instituídos e considerados naturais, que buscam estabilizar o processo vital através de estratégias de normalização, de formas hegemônicas que almejam a conservação do poder e os processos instituintes, as forças de invenção de alteridade que afirmam as potências do viver. Portanto, o movimento de mulheres vibra e atua na tensão entre estas linhas.

Para nossa cartografia consideramos como linha molar, aquela que representa os conjuntos sociais e institucionais e os relacionamentos em rede que se formam e se conformam no ciberespaço, tendo como foco o movimento feminista e de mulheres no seio da blogosfera se organizando como sujeito social que busca romper com uma formação social onde o poder é masculino, regulador e hierárquico e que se quer como referente universal.

Esses movimentos de ruptura com o padrão hegemônico ampliaram a participação das mulheres representadas pela atuação das organizações feministas e de mulheres, dos conselhos dos direitos da mulher, das conferências de políticas para mulheres, ouvidorias e a isso se acrescentam as plataformas digitais e redes sociais. As mulheres-borboletas, como bem denomina Helena Paix, estão voando e alterando os fluxos e as tensões em diversos espaços sociais. 
Segundo o texto base da $4^{\text {a }}$ Conferência Nacional de Políticas para Mulheres de 2015, elaborado pela Secretaria de Políticas para Mulheres da Presidência da República e Conselho Nacional dos Direitos da Mulher, a segunda onda da presença e atuação marcante dos movimentos feminista e de mulheres ressurge em 1970, quando as mulheres lutaram pela restauração da democracia e contra o processo histórico de exclusão feminina e pela inclusão de seus direitos humanos na sociedade brasileira (BRASÍLIA, 2015).

Nos anos 90 do século XX a luta política das mulheres continua avançando com a realização de conferências internacionais que marcaram 0 reconhecimento definitivo do papel das mulheres no processo de desenvolvimento no Brasil e no mundo. No final desta década, recomendações propostas pela pressão do movimento feminista e de mulheres foram incorporadas de certa forma à agenda da política nacional, forçando a institucionalização de políticas públicas voltadas para as mulheres.

Segundo o mesmo documento, nos últimos trinta anos o movimento feminista e de mulheres brasileiras avançou por todo o território nacional e se constitui como uma poderosa narrativa de desconstrução das desigualdades históricas estabelecidas entre homens e mulheres:

[...] a força das mulheres se expressa nos movimentos sociais, associações de bairros ou grupos de mães e comunitários, sindicatos, associações classistas e em inúmeras redes feministas. Esta variedade da representação política das mulheres espelha a pluralidade da população brasileira feminina composta de mulheres negras, brancas, das diversas etnias nacionais, lésbicas, travestis e transexuais que anseiam construir um Brasil igual para todas e todos (BRASíLIA, 2015, p.07).

$\mathrm{Na}$ construção desse país sem desigualdades, não se pode ignorar o fenômeno do ativismo feminista no ciberespaço e esta tem sido uma prática eminentemente formada pelas jovens mulheres revitalizando o campo e incluindo outras, independente da geração na militância. Suas propostas de "[...] novas formas de comunicação e ação política a partir do uso das novas tecnologias reivindicando a presença das mulheres também no ciberespaço" (MACHADO, 2010, p. 237) representam uma fatia representativa de mulheres que fazem das suas narrativas, bandeiras fincadas pela construção de suas identidades.

Apesar de haver divergências de reivindicações entre os movimentos feministas e de mulheres, todas contribuem de uma forma ou de outra para trazer 
aos espaços públicos as temáticas relacionadas às problemáticas que nos envolvem:

[...] direito da mulher à sua autonomia e à integridade de seu corpo, pelo direito a prática legal do aborto e demais direitos reprodutivos, direito à proteção contra a violência doméstica, o assédio sexual e o estupro e o direito ao trabalho remunerado com proteção social e políticas de apoio ao trabalho reprodutivo (BRASÍLIA, 2015, p.09)

O blog Sapatilhando, portanto, ao pertencer a um segmento que atua no ciberespaço, ligado em rede a um portal que se denomina Blogueiras Feministas, está inserido neste ativismo como linha molecular que apresenta uma proposta de discussão e apoio às manifestações da construção da identidade de mulheres e das suas multiplicidades.

O Portal Blogueiras Feministas ${ }^{22}$ deixa claro no seu editorial qual sua proposta no ciberespaço:

\begin{abstract}
Nosso objetivo é discutir feminismo. Em suas pluralidades e particularidades. Nas suas benesses e feridas. Além disso, queremos refletir sobre questões que cercam a formação de um mundo mais justo e igualitário para TODAS as pessoas. Este é um blog político, portanto, nos reservamos ao direito de não publicar textos que sejam contrários a nossos posicionamentos. Primamos pela crítica as estruturas e instituições, não a indivíduos. Buscamos não difundir preconceitos e buscamos utilizar os princípios da interseccionalidade em nossos textos. Nem sempre somos bem-sucedidas, por isso, para que o aprendizado seja conjunto e que a mudança seja uma possibilidade de construção coletiva, preferimos que críticas sejam feitas abertamente, em público. Afinal, esse é um blog feito por muitas mãos, olhos, cérebros, dedos, pernas, ouvidos, pulmões e corações. Uma colcha de retalhos que dialoga por meio de diversas vozes, opiniões, pensamentos e personalidades. Tudo que aqui está publicado é responsabilidade nossa, como coletivo. [...] Não acreditamos em estereótipos. Não acreditamos em verdades absolutas. Não acreditamos no feminismo como uma cartilha e nem como religião. Nosso feminismo é político e está constantemente em construção. Aberto para agregar ideias, valores e conceitos. Pronto para reconhecer privilégios e contradições. Disposto a questionar universalizações e essencialismos. Temos o desafio de propor, lutar e implementar mudanças sociais que construam uma sociedade melhor para TODAS as pessoas.
\end{abstract}

Ao integrarem-se nas várias possibilidades de participação no feminismo através da rede, as mulheres desenvolvem uma apropriação simbólica acerca de quem são, identificando-se e sentindo-se parte dos mais diversos grupos geracionais, de uma concepção de mundo. O desafio que se coloca para o ativismo

\footnotetext{
${ }^{22}$ Portal Blogueiras Feministas. Editorial. Disponível em: http://blogueirasfeministas.com/about/nossamemorial. Acessado em: 25 mar. 2015.
} 
é saber "[...] usar o ciberespaço não apenas como uma ferramenta imediata de capacitação para suas necessidades estratégicas, mas para abrir seu potencial para outras" (HARCOUT, 2005, s/p).

Para Deleuze e Guattari (1996), há um perigo implícito em cada linha, em cada segmentaridade que é reconhecido pelos trajetos de suas misturas e distinções. Esse perigo torna-se explícito no sistema atual capitalista, no bojo do qual se debatem os movimentos sociais, que se apropriam intencionalmente das forças moleculares, das linhas de fuga emergentes gerando subjetividades moleculares para uma humanidade molar.

Para nos acercarmos da linha molecular que Helena traça com Sapatilhando, fizemos a leitura das postagens autorais do blog Sapatilhando para entender como as linguagens põem em jogo os novos territórios da subjetividade daquela que se narra e com esta narrativa permite que outros corpos vibrem e se manifestem simbolicamente, porque para Helena ${ }^{23}$ : "Vital é ouvir a própria voz. Proclamar a própria liberdade. Caminhar com os próprios passos. O resto são coisas dos outros, não suas (5:56 PM - 13 Mar 2013)".

Ao fazermos incursões nas postagens de 2009 a 2014, encontramos as temáticas abordadas, o mapa por onde se estende a linha de fuga ou ruptura que tensionada faz nascer o fluxo entre os corpos que vão configurar novos campos sociais e sobretudo, o processo de subjetivação vivenciado pela autora, que vai se caracterizar por fases e escolhas.

De 2008 a 2012 as postagens foram intensas, chegando a 108 no total. Nos anos seguintes a produção se reduz a 9 no total, coincidindo com o período que se dedica a outros espaços nas redes sociais, como grupos de apoio a pais e produção do blog coletivo com as leitoras de Sapatilhando. Em 2015 o blog permanece no ar, mas sem nenhuma postagem expressa e a autora não declara um encerramento, deixando o diário como em suspenso.

Isto acontece porque Sapatilhando se amplia, de blog, passa a ser uma comunidade no Facebook, na qual são postadas as hipermídias e os recursos do blog de maneira ampliada. Sem, contudo, perder a identidade original:

\footnotetext{
23 Disponível em: http://www.sapatilhando.com.br/2013/08/quando-distancia-doi-menos-quepresenca.html. Acessado em: 25 mar. 2015.
} 


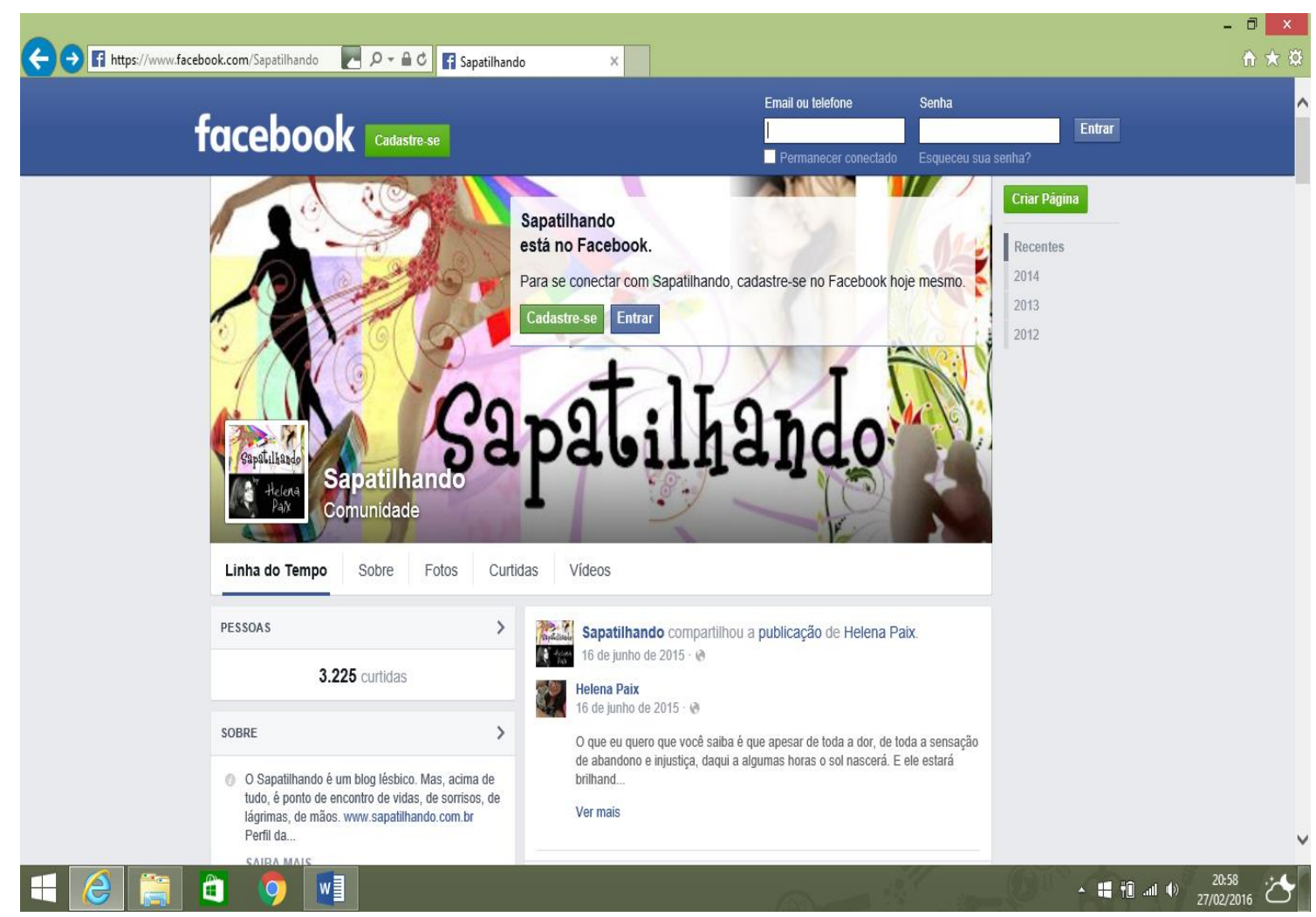

No blog quando observamos que as temáticas abordadas por palavraschave em formato de link, acessam rapidamente as referidas postagens, as quais Helena denomina de Ritmo das Canções, vemos claramente que a auto-ajuda, o compartilhar experiência é onde se dá a maior produção da autora, seguida pelo tema do despertar, do acordar para a vida e para o amor:

acorda-amor (19), amizade (11), amor (12), aniversário (1), autoajuda (25), beijo (1), beleza (2), bíblia (1), caminho (1), confissão (2)conversa ( 13)

conversa som (3)cupido (1)desabafo (2) descoberta (7)direitos (2)dor (3) dúvida (6)ela me ama? (1)escolha (2)esperança (1)fidelidade (3)histórias (1) Homossexualidade

Deus (1)igualdade (1)itália (1)leskut (1)limite (3)livro (1)

livro homossexualidade família (1)mulher (1)mãe (1)Natal (1)notícia (2)novidades (2)onde-andaráminha-cabeça (3)orgasmo (1)paciência-meu-pai (7)Padre

Fábio (1)pais (1)paixão (3)Para você (1)poesia (2)por que se é homossexual (1)preconceito (2)recomeço (2) Religião (1)

sair do armário (2) sexo (5) sofrimento (1) sorrisos (2) Sou lésbica? (1)tempero (1)

tempo (1) tirinhas (3) união (1)vida (50) vício (1)

Com isso, temos claro que o desejo, desejo no entendimento de Guattari se constitui em uma micropolítica na qual o ser humano se caracteriza como 
desejante que lida durante toda a vida com três medos fundantes: o medo de morrer (ontológico), o medo de fracassar (existencial) e de enlouquecer (psicológico).

Para lidar com esses medos, o ser humano lança mão de estratégias, no entendimento de Rolnik (2007), que assumem diferentes destinos, cenários e estilos: "Aqui reside toda a riqueza do desejo. Toda a sua generosa fartura. O desejo é criação do mundo" (p.56).

Nesse movimento de criar um mundo, criar sua própria revolução e linha de fuga e ruptura, Helena conclama todas as mulheres-borboleta como ela a se irmanarem em um movimento de escrever juntas, criar uma nova face coletiva, um escrever a muitas mãos, porque assim, todas teriam voz. Não seria apenas a história de uma mulher-borboleta, seriam todas no coletivo se contando. Foi assim que a Helena convocou a todas em 2010 para escreverem juntas, porque ali não eram apenas lésbicas buscando se manifestar, porque elas eram muito mais complexas do que a lesbianidade, eram mulheres:

\section{terça-feira, 13 de abril de $2010^{24}$}

Eu, você e NOSSAS várias histórias!

Então, quando você diz que é lésbica, pelo amor de Deus, isso não te define! Isso é só mais um aspecto ao teu respeito! Não sejamos nós também reféns da rotulação única que tentam nos impor!

A escritora nigeriana Chimamanda Adichie fala do que ela chama de o perigo da "única história". E ela diz:

"É assim que se cria uma única história: mostre um povo como uma coisa, apenas como uma coisa, repetidamente, e será o que eles se tornarão."

Nós, homossexuais, sabemos que aos olhos gerais dos preconceituosos somos seres pecaminosos, somos a escória, somos os lascivos, somos os desequilibrados, somos os que pecam contra a carne e contra o espírito e até, veja bem, contra a biologia. Essa é a "única história" contada a nosso respeito.

Mas nós, que estamos dentro dessa gigantesca variedade que é a população homossexual, nós precisamos ter plena consciência de que essa "única história" NÃO É a NOSSA história !Não é a sua história!

Eu sei muito bem quais são as tuas lágrimas, dores e medos. $E$ por isso mesmo sei que isso não é tudo o que te compõe: você também é formada de sorrisos e alegrias e sonhos e momentos de paz. E a escritora Chimamanda Adichie complementa:

"Todas essas histórias me fazem quem eu sou. Mas me focar apenas nas histórias negativas é superficializar minha experiência e negligenciar as muitas outras histórias que me formam".

\footnotetext{
24. Portal Blogueiras Feministas. Editorial. Disponível em:
} http://blogueirasfeministas.com/about/nossa-memorial. Acessado em: 22 mar. 2015. 


\section{FOLHA DE S.PAULO}

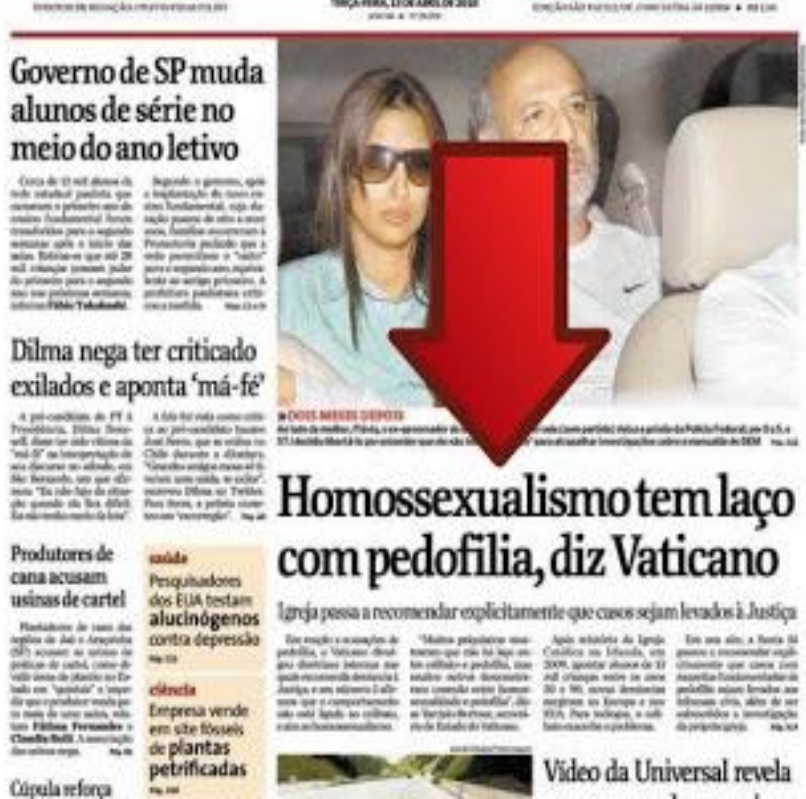

Eu quero que você não esqueça que precisamos ser lembradas sempre!

Precisamos nos lembrar de tudo o que nos compõe: precisamos lembrar que somos absolutamente normais e múltiplas e lindas e cheias de tantas e tantas histórias!

Escreve a tua história! Ela precisa ser ouvida por outros que precisam saber que os sorrisos estão aí, as vitórias estão aí, apenas na próxima hora, no próximo amanhecer, em algum lugar do futuro, apenas aguardando a hora de chegar.

Criei um novo blog, mas esse novo blog não é meu e não serei eu quem escreverei nele: será VOCÉ. Quando esses sorrisos surgirem, quando esse sentimento de paz te invadir, sempre que você se sentir vencendo seus desafios, escreva.

Esse novo blog será um Mural aonde todas nós poderemos ir para nos alimentar das várias histórias felizes e de superação e de força e de alegria que temos em nosso meio lésbico e homossexual.

Eis o NOSSO novo blog:

http://nossasvariashistorias.blogspot.com/

Enfeitarei o layout dele à medida que as histórias forem chegando!

Muitas de nós precisam saber que há MUITOS, MUITOS sorrisos em aceitar quem nós somos! Em SER quem nós somos! E precisamos sempre nos lembrar disso.

Por favor, contribuam! Façamos disso um movimento nosso! Um local aonde podemos achar nossos sorrisos e nossas várias histórias.

Os emails com as histórias ou reflexões devem ser enviados para:

nossasvariashistorias@gmail.com 
Com esta convocação Helena cria um blog no qual vários depoimentos são postados e o layout deixa claro esta construção coletiva:

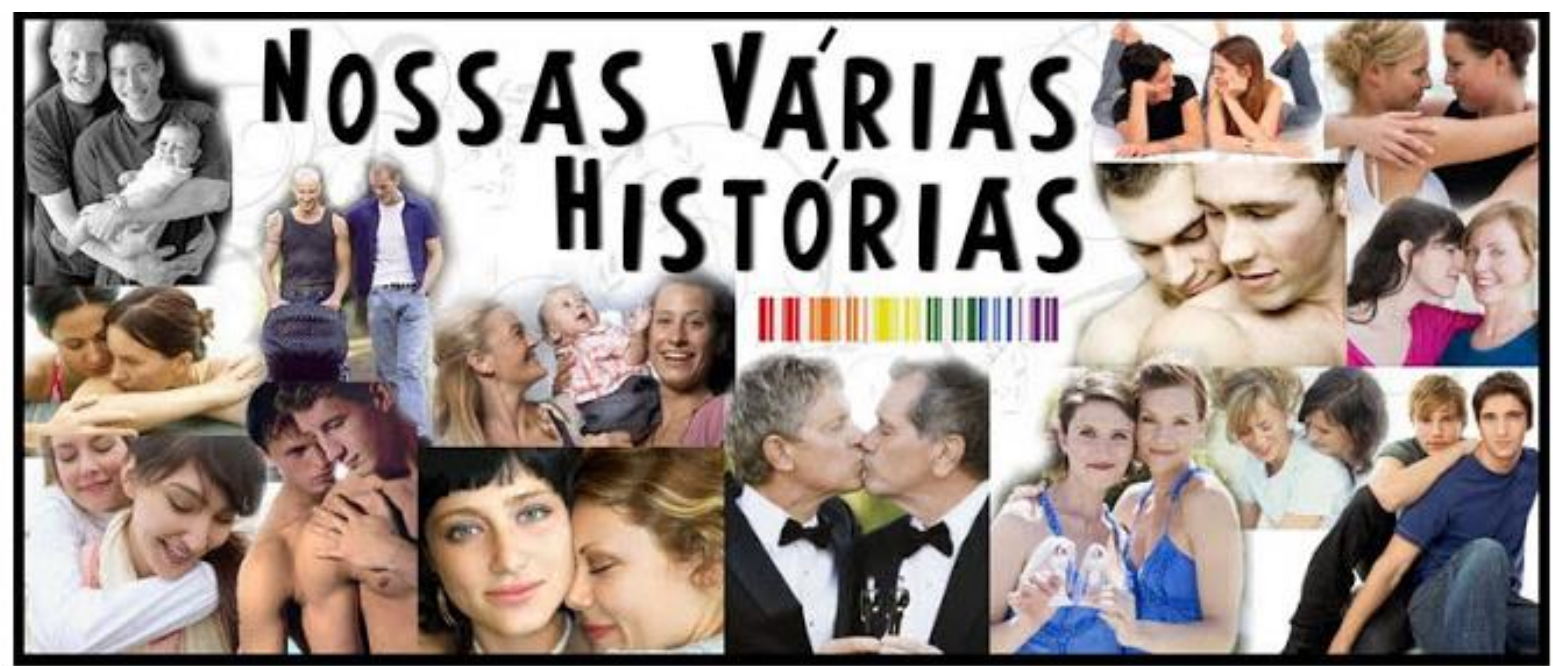

QUINTA-FEIRA, 22 DE SETEMBRO DE 2011

Toda lágrima foi válida!

ESTE BLog NÃo TEM

Minha história - Espero que seja exemplo, para que vocês nunca desistam dos seus sonhos.

UM ÚNICO AUTOR

Tem uma frase que diz mais ou menos assim:

"Não é digno de saborear o mel, quem tem medo das picadas das abelhas."

Olá meu nome é Vanessa tenho 29 anos.

Sempre namorei muito...homens é claro. Tive meu primeiro namorado com apenas 14 anos. Ficamos juntos por $5 \mathrm{e}$ t....man.....nn filhn maravilhnsa me hnie tem 11 anns. Atracão

ELE FOI CRIADo PARA SER DE TODOS OS OUE VIVEM E LUTAM E SONHAM EM PROL DE UM MUNDO MAIS TOLERANTE

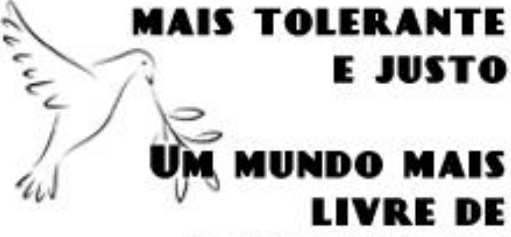
PRECONCEITOS

Uma construção coletiva que deixa de ser apenas de mulheres-borboleta, mas um devir-mulher que atinge a todos. Vemos isso no mosaico de fotos do template de abertura. Novas configurações familiares, abraços e afagos entre iguais. As postagens se caracterizam nesse espaço por depoimentos sobre a vida de cada um que ali se expressa.

O devir-mulher traz a possibilidade de produzir novas subjetividades, escapar das formas de existir oferecidas pelo capitalismo, da moral cristã e do pensamento globalizante e massificador. O devir-mulher portanto, é a linha de fuga que se traça para além de todas as identidades. A mulher pede reconhecimento, ela 
pede poder, pede direitos. Todo ser humano precisa passar pelo devir-mulher apreendendo através dos fluxos e dos movimentos como se dispor de um modo novo no mundo. Com isso, fazer os seus fluxos entrarem em ressonância com os da mulher para que algo novo possa emergir. Não ser engolido pelas representações, não ficar preso em uma identidade. Cada mulher-borboleta pode criar-se no encontro com o coletivo, sem pensar em uma identidade, isto é devir-mulher. $O$ desejo é produção, como faz Helena ao criar novos territórios, espaços que permitem novos rizomas, ligações infinitas que podemos constatar nos comentários dos leitores desse blog coletivo. Helena escreveu, provocou a escrita de outras mulheres e mais outras mulheres comentam e se veem nas histórias contadas e sentem a necessidade de ter voz e se unir em coletivo, e cada uma de sua forma questionam a identidade que a sociedade considera como a norma:

\section{8 de setembro de 2010 08:52}

Blogger B. Nobre disse...

Olá, minha história é exatamente como a sua, vivo em conflitos comigo mesma, pois amo uma mulher que inclusive é a minha ex namorada, mas não deu certo pq tive medo do mundo e do preconceito, mas ela eu sei, que é capaz de tudo pra ficar comigo! Hoje estou namorando um garoto parecido com o que vc namorou, nao existe prisões e ciumes doentios, ele é carinhoso e gentil, ele sabe que gosto da minha ex namorada e se dispôs a me ajudar esquecer esse amor e faz de tudo pra isso... finjo não sentir dor, finjo não pensar nela porque ele não merece sofrer, mas em boa parte dos meus dias é ela que me consome, é ela que me faz chorar por estar distante. Gosto dele demais, e quando ele envolve os seus braços em mim me sinto como vc se sentiu, me sinto protegida e pensando que gosto mesmo de homem, é até engraçado, porque quando vejo minha ex e quando conversamos eu penso que não conseguirei ficar longe dela nunca. Olha, já disse pra algumas pessoas que é ruim ser bissexual, porque quando estou com um homem sinto falta de uma mulher e quando estou com uma mulher eu sinto falta de um homem (isso quando o relacionamento é sério). Não dá pra viver bem assim, nunca! Muitos Beijos e adorei muito sua história.

26 de setembro de 2010 17:17

Anônimo disse...

nunca me identifiquei tanto com uma história. por muito tempo me exigi uma posição, um veredicto, pra me sentir confortável, talvez também para dar conforto aos outros. sou hétero ou sou gay? sou bi? hm chegamos a mesma conclusão: uma definição, que não nos contem, nos priva a liberdade de sentir. sigo feliz sendo apenas eu mesma e amando :) 
Helena ergueu sua voz, saiu do casulo e quando borboleta não voou sozinha, traçou uma linha de fuga que se tornou roteiro e mapa para o fluxo contínuo de outras mulheres como ela, como nós, multiplicidades que não se encaixam em modelos, que se territorializam e desterritorializam em um movimento sem fim. Com isso, estas mulheres ultrapassam um limiar, atingindo um continuum de intensidades que não valem mais do que por elas mesmas, encontrando um mundo de intensidades rizomáticas, onde todas as formas se desfazem em proveito de uma matéria não formada de fluxos desterritorializados (DELEUZE; GUATARI, 1996, p. 20).

\subsubsection{Sapatilhando e seus círculos em movimento}

Desse emaranhado geométrico de linhas temos o modo de composição das redes que define o plano de imanência, no qual repousa a aventura cotidiana da vida, onde todos são afetados por todos em graus de latitude e longitude.

Esse emaranhado geométrico é o mostrar-se de um sujeito que busca sua liberdade ao se biografar. Para Fiori (FREIRE, 1987, p. 10), no entendimento de Freire quando o alfabetizando conta de si, ele se autoriza:

Talvez seja este o sentido mais exato da alfabetização: aprender a escrever a sua vida, como autor e como testemunha de sua história, isto é, biografarse, existenciar-se, historicizar-se. Ao objetivar seu mundo, o alfabetizando nele reencontra-se com os outros e nos outros, companheiros de seu pequeno "círculo de cultura". Encontram-se e reencontram-se todos no mesmo mundo comum e, da coincidência das intenções que o objetivam, ex-surge a comunicação, o diálogo que criticiza e promove os participantes do círculo. Assim, juntos, re-criam criticamente o seu mundo: o que antes os absorvia, agora podem ver ao revés. No círculo de cultura, a rigor, não se ensina, aprende-se em "reciprocidade de consciências".

Segundo Freire (1987) para compreender o mundo, ter consciência dele, o homem precisa indagar-se, com isso o ser humano desperta potencialidades e mobiliza sua capacidade de optar, de decidir, de escolher. Desta forma, exerce sua liberdade de escolha e nesta ação que desenvolve não muda apenas o mundo, muda sua posição diante do mundo. Por isso, Freire deu tanta ênfase ao diálogo que deve ser direito de todos e ao movimento que o constitui (ação- reflexão-ação) que ao objetivar-se em diálogo comprometido dos sujeitos, nomeia e reflete sua práxis. 
Ao criar em torno de si uma comunidade de leitores, Helena, a autora do blog dialoga com eles e na reciprocidade dessa relação fortalece o círculo de cultura Sapatilhando, que em si já é a representação de uma palavra geradora, porque metaforiza o movimento e as piruetas dos processos de descoberta de si. Mulheres juntas construindo um universo de palavras que a presentificam e as transformam em sujeitos da própria história mediante a palavra que as hominiza.

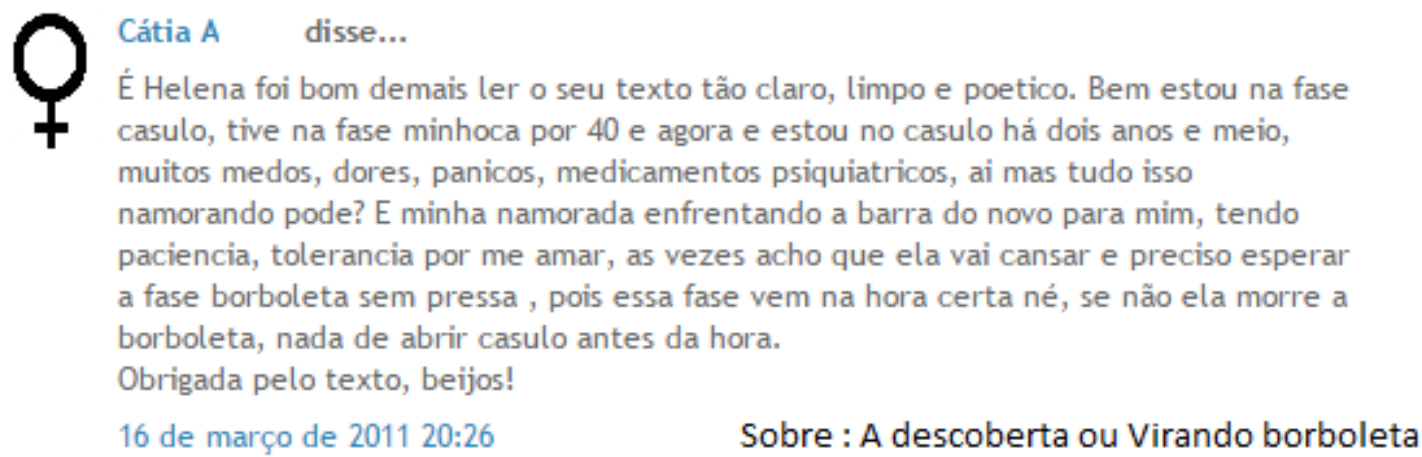

Ao identificar-se com Helena, a leitora assume as fases do processo de subjetividade para si, nomeia seu processo como se fosse a autora, marca o tempo de cada fase, a primeira de minhoca dura 40 anos e de casulo dois anos e meio.

Desta forma o diálogo assume um caráter de chamamento a favor da valorização da palavra e da escuta dos participantes do processo. Helena ao escrever de si age como um elemento provocador da ação pelas palavras que transformadas pela criticidade dialética e dialógica das suas leitoras, tornam-se palavra-ação, atividade humana de significação e transformação do mundo. Nesse sentido, o diálogo como palavra-ação além de fazer a crítica em forma de discurso se compromete concretamente com aquilo que denuncia e/ou anuncia. A leitora anuncia na sua postagem que se reconhece mulher-borboleta e que precisa saber a hora certa de assumir sua fase de ser alado que se transformará e ganhará outros espaços. Ela adverte também que não está sozinha neste processo, há uma outra que a apoia e dá energia. Mulher como ela, que se dispôs a dar suporte ao processo da outra, como um círculo que agrega outros círculos.

A leitora reafirma com isso que precisamos do outro para nos reconhecermos como humanos. Ela precisa de Helena para se identificar, precisa da namorada para se apoiar, porque "É na prática de experimentarmos as diferenças 
existentes que nos descobrimos como eus e tus. A rigor, é sempre o outro, enquanto tu, que me constitui como eu, na medida em que eu, como tu do outro, o constituo como eu" (FREIRE, 2000, p.96). No mesmo círculo teórico, também Bakhtin (2004), reconhece a influência que o outro exerce sobre o eu quando afirma que o eu é formado por palavras do outro que são incorporadas, assumidas e modificadas pelo eu.

Nesta relação com o outro, constroem-se reflexões mais profundas como da leitora Flávia:

\footnotetext{
Flávia disse...

Durante muito tempo eu tive problemas com essa coisa de rótulos. Um, porque achavam que eu era inteligente demais pra ser bonita. Dois, porque em outra fase achavam que eu era bonita demais para ser inteligente. Três, porque no início da minha adolescência achavam que eu era moleque demais para ser hetero. Quatro, porque numa fase mais tardia achavam que eu era feminina demais para ser levada a sério por mulheres. E esses, como tantos outros rótulos, só pararam de me incomodar quando entendi que, mais do que não pertencerem a mim, eu é que não pertencia a nenhum deles. E hoje eu me assumo como sou, nem tão bonita nem tão feia, nem tão inteligente nem tão rasa, nem tão uma coisa nem tão outra, mas eu, e como eu não há ninguém. Essa é a beleza.
}

Beijos!

16 de dezembro de 2008 00:23

Sobre: Nomes, sobrenomes e lesberdade

Esta mulher-borboleta que questiona os rótulos e perfis construídos socialmente, porque há consciência por parte dela da sua perenidade e mutação. Sentimento que Freire assim expressa: "Gosto de ser gente porque a História em que me faço com os outros e de cuja feitura tomo parte é um tempo de possibilidades e não de determinismo. Daí que insista tanto na problematização do futuro e recuse sua inexorabilidade" (FREIRE,1996, p.22).

Flavia tem consciência da sua inconclusão, do seu inacabamento, mas vê nele também sua razão der bela, por ser única, confirmando as multiplicidades na visão de Guattari e o ser processo que Freire aponta:

Inconclusos somos nós, mulheres e homens, mas inconclusos são também as jaboticabeiras que enchem, na safra, o meu quintal de pássaros cantadores, inconclusos são estes pássaros como inconcluso é Eico, meu pastor alemão, que me saúda contente no começo das manhãs (FREIRE, 1996, p.23). 
Lorena outra leitora, por sua vez, de modo coloquial enfatiza que a autora do blog escreveu tendo em vista suas expectativas e mais que isso personifica 0 texto por si só, alegando que ele pode ler a leitora: "[...] é bom e ruim chegar num texto e sentir que ele ti lê":

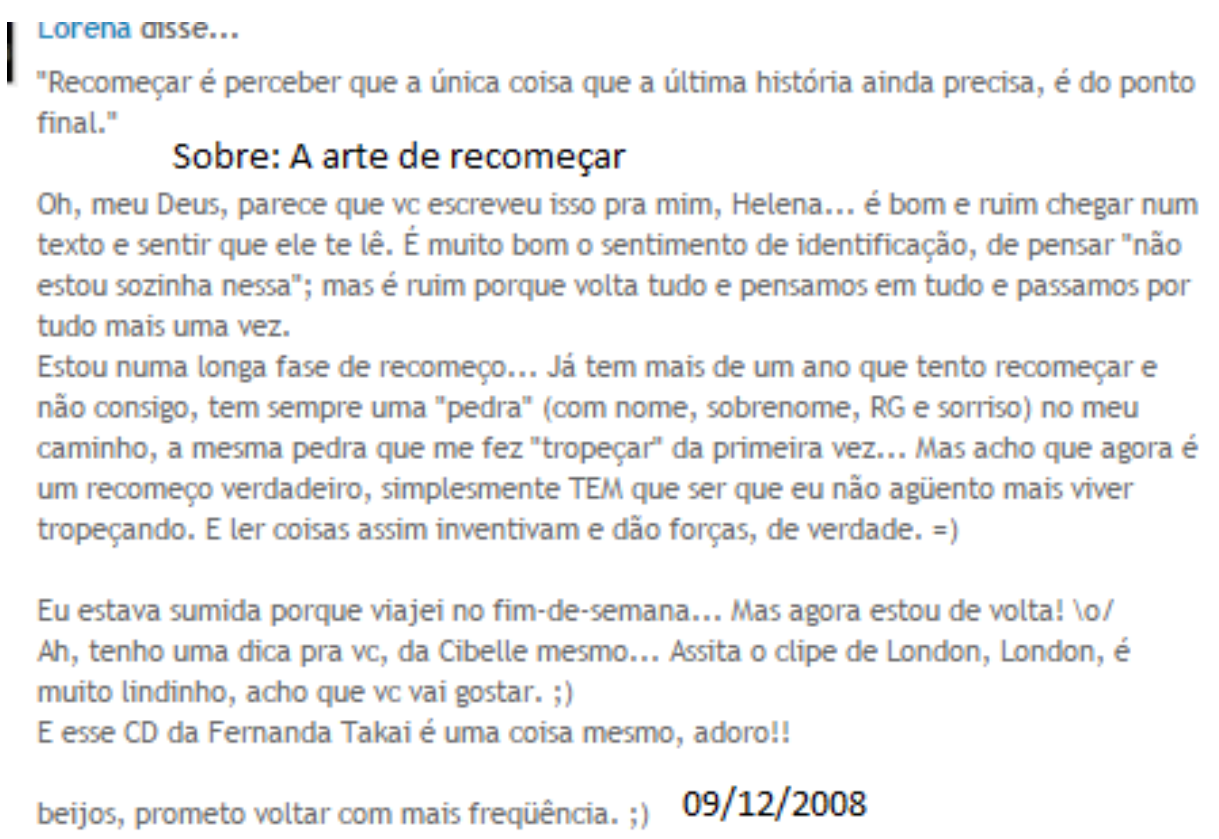

Com este comentário, a leitora dá ênfase ao diálogo que se realiza em uma triangulação entre autora/leitora/texto levando ao máximo a circularidade que a palavra transformadora realiza. Como Fiori, tão bem sintetiza ao falar do pensamento freireano no prefácio da obra Pedagogia do Oprimido (FREIRE, 1987, p. 21):

Palavra que diz e transforma o mundo.

A palavra viva é diálogo existencial. Expressa e elabora o mundo, em comunicação e colaboração. O diálogo autêntico - reconhecimento do outro e reconhecimento de si, no outro - é decisão e compromisso de colaborar na construção do mundo comum. Não há consciências vazias; por isto os homens não se humanizam, senão humanizando o mundo.

O movimento dialogal entre Helena, a autora e suas leitoras é uma via de mão dupla, as segundas postam no blog Sapatilhando e Helena visita-as em seus blogs, comentando as postagens daquelas e fortalecendo as linhas de fuga e ruptura que cada uma ao seu modo e no seu ritmo construíram. 
Com isso se formam círculos dentro de círculos que permitem fluxos constantes e cadeias rizomáticas criando uma cultura própria, uma comunidade com suas regras e seus vocabulários.

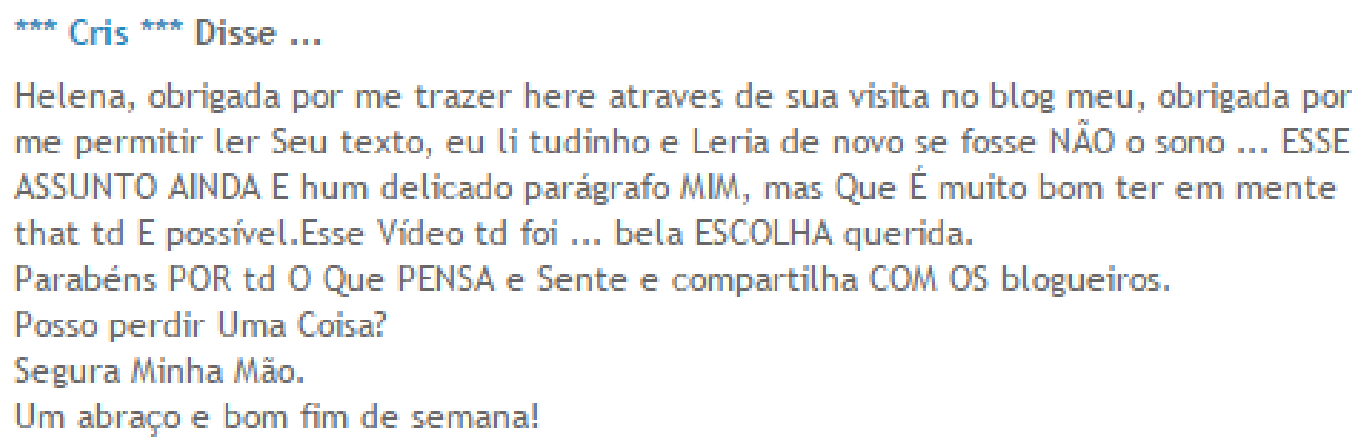

Comunidade que cria uma intimidade tão profunda que possibilita uma construção coletiva de texto e de histórias. E desta forma desenvolvem uma consciência de mundo, da necessidade do outro para se constituir, assim relembramos o trecho de Pedagogia do Oprimido (2014) quando Freire relata um episódio com um camponês no Chile que afirma não existir o mundo sem o homem, porque o homem é o único capaz de usando da palavra nomear o que vê, e o que sua consciência considera:

Na verdade, não há eu que se constitua sem um não-eu. Por sua vez, o
não-eu constituinte do eu se constitui na constituição do eu constituído.
Desta forma, o mundo constituinte da consciência se torna mundo da
consciência, um percebido objetivo seu, ao qual se intenciona. Daí a
afirmação de Sartre, anteriormente citada: "consciência e mundo se dão ao
mesmo tempo". Na medida em que os homens, simultaneamente refletindo
sobre si e sobre o mundo, vão aumentando o campo de sua percepção, vão
também dirigindo sua "mirada" a "percebidos" que, até então, ainda que
presentes ao que Husserl chama de "visões de fundo", não se destacavam,
"não estavam postos por si". Desta forma, nas suas "visões de fundo", vão
destacando percebidos e voltando sua reflexão sobre eles (FREIRE, 1987,
p. 68).

A autora do blog Sapatilhando não apenas nomeia o mundo, mas também o colore e convida outras mulheres para o processo. Helena quando se dirige às leitoras, por meio dessa relação, interage com o outro, atua sobre ele, leva-o a aceitar o dito e a realizar o que se propõe. Esta dimensão constitutiva da língua se faz presente na construção e nos efeitos de sentido do discurso, na compreensão ativa e responsiva, como numa réplica, suscitando sempre uma reação, uma 
resposta do interlocutor. Nessa relação contínua, Helena, nossa autora, leva em conta como se assimilam as palavras alheias, como são criadas constitutivamente as respostas contextuais e como as práticas sociais influenciam os modos de interação com seus leitores.

Desse modo, podemos afirmar que a interação verbal envolve dois ou mais sujeitos, que interagem por perguntas e respostas, mesmo sem a presença do outro, pois a pergunta ou a resposta podem ser constituídas por um só, ou seja, o diálogo de um sujeito consigo mesmo, já que o eu não existe sem o outro, nem o outro sem o eu, tanto que o silêncio também vincula uma enunciação, como bem esclareceu Bakthin:

A enunciação enquanto tal é um produto da interação social, quer se trate de um ato de fala determinado pela situação imediata ou pelo contexto mais amplo que constitui o conjunto das condições da vida de uma determinada comunidade linguística (BAKHTIN, 2002, p. 121).

Esta interação se explicita de forma clara na postagem de Helena quando crê estar se autobiografando:

\section{As incríveis mulheres-maravilha e as cores que elas têm para colorir o mundo /}

Este será um post longo. Sim, eu sei o que você está pensando: Helena, todos os seus posts são longos!

Eu sei. Eu sei... Mas este será maior ainda. Oo Sorry...

$E$ que hoje eu estou me sentindo auto-biográfica. : $P$

$E$ porque uma visitante querida do blog me perguntou sobre a minha história e eu achei por bem juntar uma coisa à outra (coisa que gosto muito de fazer) e vir pensar por aqui - com nós todas pensando juntas, o pensamento fica melhor, não é? ;] Peço que, se você se cansar, você mesma 'quebre' este post em dois: e volte mais tarde para ler o resto, tá? Foi mal... estou mesmo com vontade de conversar...

(Postagem de dezembro de 2008)

Esta vontade de conversar de Helena tem a força do círculo de cultura que se forma, pensar sozinha não possibilita para a narradora um pensar melhor, um pensar que possibilite o diálogo na perspectiva freireana:

O diálogo fenomeniza e historiciza a essencial intersubjetividade humana; ele é relacional e; nele, ninguém tem iniciativa absoluta. Os dialogantes "admiram" um mesmo mundo; afastam-se dele e com ele coincidem; nele põem-se e opõem-se. Vimos que, assim, a consciência se existência e busca perfazer-se (FREIRE, 1987, p. 79). 
Quando Helena se propõe a pensar no espaço virtual para estar junto e pensar junto com suas leitoras, ela tem claro que a consciência do mundo, busca-se ela a si mesma num mundo que é comum; porque é comum esse mundo, buscar-se a si mesma é comunicar-se com o outro. $O$ isolamento não personaliza porque não socializa. Intersubjetivando-se mais, mais densidade subjetiva ganha o sujeito (FREIRE, 1987).

Ainda na mesma postagem Helena afirma:

Eu sou a única mulher entre dois homens. Um mais velho e outro mais novo. Pois é, eu sou a equilibrada e conciliadora filha-do-meio. :P

Se meus pais sabem de minha orientação sexual?

Não. Não sabem.

Meus pais são dois dos seres humanos mais lindos que conheço. São super-pais. Uma coisa linda de se ver! São pessoas boas, corretas, deliciosas mesmo. Sou incrivelmente sortuda de ter sido amada sempre. Sempre. Já nasci em meio ao amor. E sei o valor disso.

Acontece que eles não podiam ser perfeitos, não é? :P

Ninguém é!

Então eles realmente não entendem, criticam e não aceitam homossexuais. Para piorar um bocadinho as coisas, ainda são extremamente católicos, 0 que coloca o homossexualismo como um dos piores 'pecados' que possam existir.

Se isso me machuca?

Um dia já me machucou sim. Hoje vejo que é exatamente a questão que nós, seres coloridos, pedimos sempre: que o diferente seja respeitado.

Para Freire e Fiori (FREIRE, 1987), a palavra, como comportamento humano, significante do mundo, não designa apenas as coisas, transforma -as; não é só pensamento, é "práxis". Práxis que para Helena, nossa narradora, precisa ser gestada considerando a beleza e a forma de ser do outro com quem ela vive e se comunica. Os pais são lindos como ela diz, veem o mundo de outra forma, mas nem por isso, deixam de ser respeitados naquilo que pensam porque é esse movimento de respeito que ela anseia enquanto diferente deles.

Assim como Freire, Helena, a autora do blog, acredita que a palavra é viva, é diálogo existencial, e por ela expressar e elaborar o mundo, há um compromisso do blog Sapatilhando em construir um mundo em comum com suas leitoras, daí o bloco ou espaço virtual, que foi intitulado "Dança comigo", ser um texto vivo que se atualiza em tempo real, perguntas que chegam de modo incessante, em um movimento frenético de palavras se sobrepõem na tela: 


\section{:: dança comigo? :::}

LyaSmith: ... this is the application for Android TV series I have told $u$ about it http://x.co/7siFg

9 Dec 14, 20:12

Adrix: Olá Helena gostei bastante do seu texto, de verdade foi um trabalho muito arduo e perfeiro. Agora eu tenho um problema, isto é sobre a ejaculação precoce, por tanto gostari que desses umas dicas.

20 Oct 14, 10:17

Mayara: Muito obrigada,por cada palavra. me ajudou e continua ajudando para a minha libertação!

7 Oct 14, 21:36

karol: meu face eh karolyne peabody robbins fala por inboxx

7 Oct 14, 21:34

karol: Oi helena gostei muito do

O movimento do círculo Sapatilhando vai além dos limites do blog, Helena, conclama suas leitoras para estar com ela, em outras redes, outros sites, tecendo outros textos. Textos que podem assumir outros formatos. No site Parada Lésbica o convite é para parceria, companhia, no Facebook é um movimento de adição, soma à uma comunidade, no Twitter é para trilhar novos caminhos. Em suma, são círculos dentro de círculos em movimento de pedra jogada na água que se reproduz em espirais:

::: me faz companhia lá no Parada! :::

É só clicar na imagem! ;]

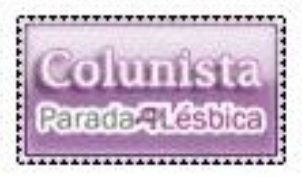

:::pra conversar:::

- email(prefiro!): helenapaix@gmail.com

- MSN: adoradomar@hotmail.com

::: Me adiciona lá no Face! :::

\section{facebook.}




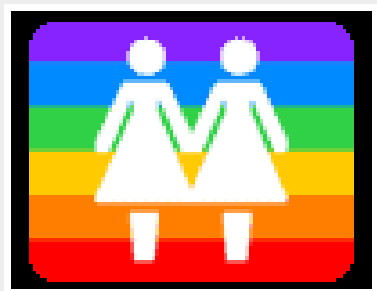

Helena entretanto não pára nos círculos de leitoras apenas, Helena busca aglutinar-se também em um rede que apoia, uma rede que sustenta e que se solidariza com outros movimentos. Movimentos religiosos, grupos de pais de homossexuais, grupos de jovens LGBT, porque como o bloco se nomeia, e nele também visualizamos que há seguidores do blog que além de ler, interagir, também seguem, em um movimento de construção de uma comunidade que sapatilha, que circula, que se movimenta e que se constrói como rizoma, como círculo, como rede, como corpo que vibra, porque o desejo está em tudo e a todos afeta e agencia em maior ou menor grau:

:::Amar a Deus é justamente saber reconhecê-lo nos vários tipos de amor::

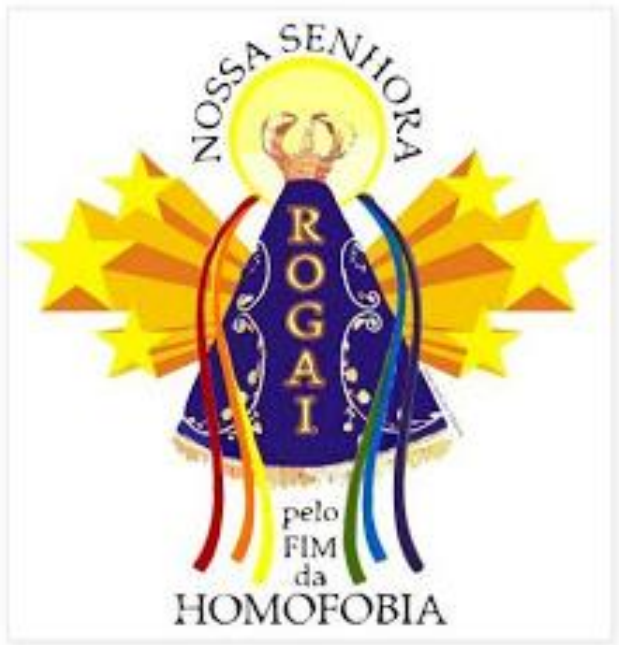

:Associação de Jovens LGBTS:

rede ex aequo 

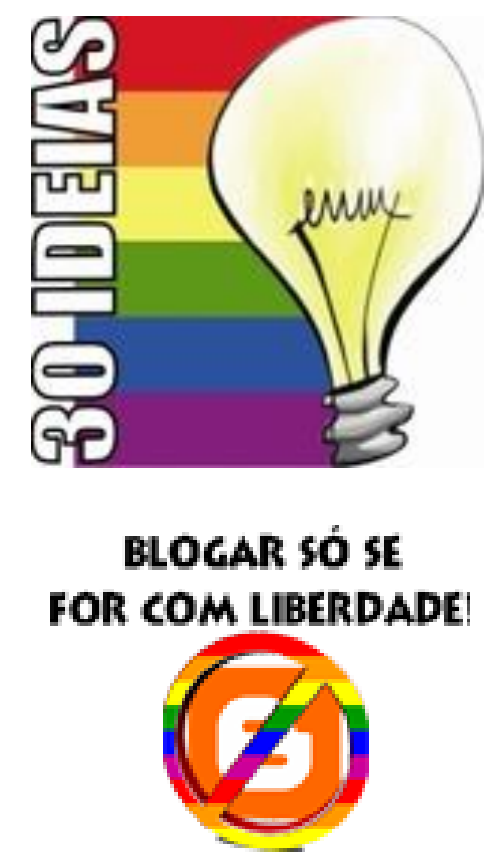

:::quem dá as mãos:::

Membros (546) Mais » Aqui o próprio ambiente registra o número de seguidores do blog Sapatilhando.

Um hipertexto, como é de sua natureza permite que façamos novas leituras a cada novo acesso, novas portas se abrem a cada clique, mas para que possamos ter um panorama da leitura que fizermos buscamos conclusões e expansões, sempre em movimento de recomeço. 


\section{CONCLUSÕES E EXPANSÃO DE NOVOS CÍRCULOS}

Cartografar é um movimento de expansão no qual a cartógrafa, porque é do lugar do feminino que me pronuncio e que me autorizo, se territorializa e se desterritorializa. Como corpo vibro e sou afetada por todo o percurso de construção da pesquisa que é busca de si no outro e no fenômeno para o qual voltei meu olhar e minha emoção.

O texto humano para o qual meu desejo de busca se voltou, trazia em si muito daquilo que eu, cartógrafa, via em mim mesma, na minha escrita e nos meus processos de subjetivação. Sapatilhando era o movimento que eu realizava quando via na minha história a história de todas as mulheres-borboleta apontadas por Helena. Elas estavam nela e nela estava eu.

A escolha do círculo como imagem que perpassa toda a construção dessa tese não foi uma escolha aleatória, foi uma escolha proposital. Esta escolha se baseia em imagens da infância que trabalha com a ideia de contar histórias em círculo e a partir deles se descobrir no mundo como construtor da sua própria história.

Esta imagem também se liga à ancestralidade das danças rituais tribais nas quais as mulheres em torno do fogo cantavam e entoavam suas evocações aos espíritos que traziam o esclarecimento. Não há bruxas sem círculos. Não há religiosidade de matriz africana sem giras e rodas. Não há educação sem círculos de cultura e troca de saberes. Acredito que um educador age e se constitui nos movimentos da linguagem e do humano que o processo educativo verdadeiro se alimenta.

Helena, a autora, a mulher, a militante, a educadora em última instância, colocou em ato aquilo que Freire aponta como o ensinar e aprender. Há nela a vocação ontológica de ser mais como bem descreve o autor em Pedagogia da Autonomia.

A autora de Sapatilhando, mais do que um ser no mundo, como defende Freire sobre o ser humano e seu processo de constituição, tornou-se uma presença no mundo, com o mundo e com os outros: 
Presença que, reconhecendo a outra presença como um "não-eu", se reconhece como "si própria". Presença que se pensa a si mesma, que se sabe presença, que intervém, que transforma, que fala do que faz, mas também do que sonha, que constata, compara, avalia, valora, que decide, que rompe (FREIRE, 1996, p. 20).

E na troca de vivências, no relato do seu sentir e ao se abrir para a possibilidade da dialogia com suas leitoras, se instaura um genuíno processo educativo, no qual Helena, na perspectiva freireana, se forma e re-forma ao formar e quem é formado forma-se e forma ao ser formado.

Igual processo se instaurou em mim nessa tese, no contato com os círculos teóricos que deram sustentação à sua leitura de Sapatilhando, quando como educadora vislumbrei na linguagem, a possibilidade e o caminho para construção da subjetividade de Helena e da minha própria.

No diálogo com o pensamento bakthiniano, percebi que a escrita de si realizada por Helena, e a escrita da tese se fundam no conhecimento de si, porque para este autor, eu chego a ser eu mesma só quando me manifesto para um outro, através de um outro e com a ajuda de um outro. Cada vivência minha, cada vivência de Helena e de suas leitoras, não se bastam por si mesmas, estão voltadas para um exterior, está dialogizado e nesse intenso encontro está a razão de ser das subjetividades humanas e suas multiplicidades, naquilo que podemos considerar como vida cotidiana de natureza movente e responsiva.

A fala cotidiana é responsiva, se faz numa pedagogia da pergunta. A cartografia é um indagar sobre e um indagar-se de si diante de um dado fenômeno que evoca e chama à reflexão. Nesta atividade está contida a visão de mundo, a vivência, o sentir e o estar no mundo da cartógrafa.

Para a leitura de Sapatilhando, usei uma lente minha, filtrada pela lente de autores, usei uma palavra minha, mas como entende Bakhtin, uma palavra semialheia, até que na tese ela foi povoada com a minha intencionalidade e minha expressividade.

Nesse movimento de interação social entre eu-cartógrafa, Helena e suas postagens, as leitoras e seus comentários, gerou-se novos efeitos de sentido, tornando-se círculos dentro de círculos que se conectam e dão novos movimentos de entendimento de si e do mundo. 
Esta construção de si tendo em vista a parceria com outro ou outros é amplamente vivenciado por Paulo Freire ao longo da sua produção acadêmica e autoral. Pedagogia da Pergunta, escrito com Faundez, é claramente uma obra dialogal, uma construção com um outro que não impede que haja uma identidade dele enquanto autor em outras obras. O fazer junto, o escrever junto e na troca, é uma marca da educação que se quer humana, amorosa e eivada de humanidade:

Agora, convencidos da validade de fazermos juntos um livro dialógico [...], estamos aqui em torno de uma mesa para "conversar" um livro. E ao fazêlo, estamos aceitando, responsavelmente, nos expor a uma experiência significativa: a de um trabalho em comunhão. [...] Concordo com você (Faundez falando) nesta análise, sobretudo no que você verifica a respeito da ruptura da acomodação intelectual, ou seja, esta tentativa de fazer com que o trabalho intelectual seja um trabalho coletivo (FREIRE; FAUNDEZ, 1985, p.06)

Esse fazer coletivo foi favorecido no blog Sapatilhando pelas linguagens midiáticas empregadas pela autora, suas postagens trabalharam intensamente os recursos que o hipertexto adota, e deles usando com liberdade. Com isso, se transforma no seu próprio editor, não há censura e cria quantos links quiser para tornar seu texto um rizoma infinito.

Helena, a autora, usa e abusa de diversas fontes de letras, de tamanhos ou corpos para dar concretude à sua fala que evoca. Lança mão da primeira pessoa na maioria das suas postagens, de modo coloquial, e utiliza recursos de linguagem para aproximar o leitor até fisicamente de si, como se falasse ao seu ouvido. Com isso, o blog se transforma em um espaço de intimidade no qual mulheres-borboletas se comunicam e dialogam, chamando para si o discurso do reconhecimento de umas nas outras.

Esta possibilidade se dá porque as novas tecnologias midiáticas instauram uma estética do fluxo, em um trânsito contínuo, em um devir:

Em alguns casos, a ideia é fazer desaparecerem as interfaces externas, permitindo um acoplamento mais simbiótico entre os elementos biológicos e os digitais. [...]. É a incorporação da ideia de relação, isto é, de um fluxo de comunicação e informação que se estabelece entre os agentes que compõem a obra, como é o caso dos trabalhos colaborativos (SANTAELLA, 2007, p.29).

O desenvolvimento desse tipo de espaço comunicacional como no caso de Sapatilhando, é um bom exemplo de como desenvolver a autoria, favorecer uma 
escrita significativa e responsiva diante do mundo no qual está inserido o ser humano, e a cada vez que a palavra constitui a identidade daquele que escreve, mais ele vai em busca de outras linguagens para comunicar de si, e não apenas usar as linguagens como ferramentas desprovidas de sentido e significado. Helena escreve, Helena fala e grava sua fala, Helena filma sua intervenção diante das realidades cotidianas que a tocam e tudo isso se registra no blog. Sapatilhando é um registro dinâmico do afeto e da vibração de Helena e suas leitoras. Daí tantos links de outros blogs serem disponibilizados, tantos links de vídeos que possuem intertextualidade com a realidade que ela está vivendo.

Ao mesmo tempo que fala de si, Helena se torna um observatório do mundo e dá acesso para que outros possam acessar tantas informações forem necessárias para que também se fortaleçam e possam dizer de si.

Essa é uma roda de conversa, um círculo de cultura, uma gira, um ritual no qual as mulheres se irmanam para se fortalecerem diante da sociedade que cria moldes fixos para tentar enquadrar as multiplicidades humanas:

O ser humano contemporâneo é fundamentalmente desterritorializado. Com isso quero dizer que seus territórios etológicos originários - corpo, clã, aldeia, culto, corporação - não estão mais dispostos em um ponto preciso da terra, mas se incrustam, no essencial, em universos incorporais. A subjetividade entrou no reino de um nomadismo generalizado (GUATTARI, 1992, p. 169).

Para o autor, os jovens mesmo em posse dos mais modernos recursos tecnológicos, ouvindo em seus aparelhos eletrônicos os mais variados sons e imagens, de tempos até imemoriais, não tem mais de fato suas terras natais como um lugar determinado. Tudo circula e tudo flui, mas este lugar de origem, de natalidade está perdido. Mas há possibilidades de superação disso quando buscamos construir juntos alternativas:

As terras natais estão definitivamente perdidas. Mas o que podem esperar é reconstituir uma relação particular com o cosmos e com a vida, é se recompor com sua singularidade individual e coletiva. A vida de cada um é única. O nascimento, a morte, o desejo, o amor, a relação com o tempo, com os elementos, com as formas vivas e com as formas inanimadas são, para um olhar depurado, novos, inesperados, miraculosos (GUATTARI, 1992, p. 171).

A medida que a blogosfera se torna um território, e nele se criam comunidades virtuais e diários eletrônicos, cria-se um mundo, com suas regras, seus 
acordos, suas relações e inter-relações. O blog Sapatilhando é um nó rizomático que compõe esse tecido. Tecido vivo que tem sua semiose construída na interpenetração das linguagens que o compõe.

Isto se dá porque a espécie humana desenvolveu complexos sistemas de representação da realidade. Segundo Santaella (2007), para realizar nossas ações no mundo, desenvolvemos sistemas representacionais simbólicos que utilizam uma invenção visiográfica que se constitui de imagens e textos que passam a compor o registro construído e mantido por gerações sucessivas.

Quando Helena, constrói Sapatilhando, ela realiza esse movimento de busca de processos de subjetivação e simbolização que possam propiciar a construção da sua identidade a partir das suas multiplicidades.

Esta ação de Helena, a autora de contar de si é uma revolução molecular para a qual podemos olhar e dela perceber em ato o E-ducere, trazendo-a para fora de si mesma, para que compreenda e dê a compreender que ela e as outras são mais que elas mesmas.

Além de sermos seres biológicos, demonstra a autora, somos membros de uma coletividade que precisa dar-se conta do poder que possui. Este é um movimento de concretizar o homo que se define pelos laços que tece com os demais.

Quando pensamos em agir em rede, construir rizomas, estamos apontando para a certeza de que o ser humano pode contribuir para a construção de uma cidadania onde todos possam usufruir a partir do acesso aos bens culturais, de uma prática de questionar mais abertamente seu destino. E nesse movimento, nenhum pode ficar de fora da rede humana, permitindo a todos que sejam eles mesmos com relação ao olhar dos outros. Esta relação se dá porque a linguagem é uma atividade de construção de sentido e isto abre um amplo espaço para a ação educativa, onde cada troca de saberes é uma construção em que o sentido das palavras é disputado, revisto e repensado.

No blog Sapatilhando favoreceu-se a construção de saber, a mudança de status, de todos aqueles que ali estavam se educando em círculo. Todos passaram à posição de autores ou coautores de seus saberes. 
Tanto Freire quanto Bakthin reforçam a ideia de que a língua só tem sentido quando ela coloca os seres humanos em interação, negociando sentidos a partir de uma situação de construção de saber, retrabalhado e reinterrogado pela e na linguagem.

A cartógrafa a partir das reflexões provocadas pelo processo de subjetivação de Helena e suas leitoras, traz também para o círculo sua vivência de educadora atuando na rede pública de ensino, tanto na docência quanto na gestão central do sistema, contribuindo com diversos processos de construção de propostas e projetos que buscam um novo fazer educativo.

Portanto, não pode deixar de ver as experiências desenvolvidas na construção dos currículos escolares como narrativas, da organização do tempo e dos espaços escolares e não escolares que tem nos ciclos e nas trilhas de aprendizagem um caminho que concebe a educação como processo inacabado.

Esse movimento tem acontecido desde a formação escolar na Educação Infantil, Ensino Fundamental, Ensino Médio, na Educação de Jovens e Adultos e na Educação Popular e nos Movimentos Sociais. Os seres humanos em seus processos de construção de sentidos estão em fluxo, e aprendem buscando relações de troca de saberes que privilegiam o diálogo e o contar de si.

Sem dúvida, esses movimentos de E-ducere ganham características próprias dependendo dos espaços e contextos onde acontecem. Não podemos negar que ainda se constituem como revoluções moleculares, na visão deleuziana. Entretanto, ligações rizomáticas cada vez mais intensas têm levado estas experiências a se concretizarem como políticas públicas em algumas redes de ensino brasileiras, como no Distrito Federal, Porto Alegre (RS), Recife (PE) e já ressoam fortemente na discussão da Base Nacional Comum Curricular e quiçá na construção de novas propostas de organização do Ensino Médio na perspectiva de Ciclo e Percurso de Aprendizagem, Formação Inicial de Professores para os anos iniciais de escolarização baseada na pedagogia de projetos e na intervenção.

Estas iniciativas também se dão em sistemas de ensino de outros países como no caso da Finlândia, da Austrália, da França, exemplos que tem sido fonte de estudo para os educadores brasileiros que discutem a escola e seus percursos. 
O Ministério da Educação (MEC) vive esse momento atualmente, quando abre em consulta pública online e em rodas de conversa, seminários e debates a construção do documento preliminar da Base Nacional Comum Curricular a ser apresentado ao Conselho Nacional de Educação, sendo este um movimento que aciona dispositivos de fala e reconstrução, territorializando e reterritorializando um pensar sobre a formação humana, ouvindo várias vozes e vários círculos.

Movimento esse que permitiu que dentro dele nascesse também outra revolução molecular como foi o documento construído a várias mãos apresentado nacionalmente por outro grupo governamental como contraponto a este do MEC, por ser este grupo aquele que concebeu o Programa Pátria Educadora do governo federal.

Nestas vivências de construção coletiva tem sido a tônica no Brasil atual, as conferências públicas que se organizam metodologicamente em grupos de trabalho e rodas de conversa para construir propostas que irão definir políticas públicas para os mais diversos segmentos sociais. Em todas elas, das quais a cartógrafa tem participado como militante feminista, educadora na posição de coordenadora de grupos, como delegada, como observadora, pode-se perceber que em funções e situações diversas, fica patente que a linguagem, a fala, a postura dialógica e responsiva definem e identificam o lugar e a importância das relações com o outro no processo de subjetivação do ser humano e seu lugar no mundo, no círculo a que pertence, no círculo para o qual se volta e quer pertencer e nas escolhas que faz quando se entende como ser humano constituído de multiplicidades que se constroem e desconstroem quando se abre para o trabalho no coletivo e com o coletivo.

E para exemplificar a importância da palavra na construção da subjetividade feminina e na construção dos movimentos de mulheres, com os quais a educação tem muito a aprender, transcrevo a fala de uma feminista e educadora, Tatiana Lionço, durante uma roda de conversa do Fórum de Mulheres do Distrito Federal em fevereiro de 2016 do qual faço parte desde 2010, que compartilhei em rede e online pelo Instagram:

Toda luta feminista é uma luta pela palavra. Ninguém tem o direito de dizer por mim qual a minha luta política. Como nós podemos manter nossos espaços identitários recusando a forma de ser de outra feminista? É possível manter a minha luta sem recusar a luta de outras mulheres. Posso 
ser feminista por ser mulher, independente dos lugares sociais aos quais pertencemos. Devemos nos interessar pela luta das outras mulheres (LIONCO, 2016).

Compartilhar, atuar em rede, potencializar nossas forças, unidade nas diferenças são alguns dos termos que fazem parte do vocabulário do movimento de mulheres, que tem várias faces, várias tendências, várias organizações, várias divisões, enfim, multiplicidades, inacabamentos que se espraiam de modo rizomático, seja no ciberespaço, seja no chão da escola, no chão das praças, nas marchas, nas conferências e em todos os mais diversos lugares de aprendizagem e ação de mudança, porque os territórios e os mapas se renovam e se modificam no fluxo contínuo da vida.

Podemos constatar esses movimentos na atualidade quando as mulheres no ano de 2015 desencadeiam campanhas contra o silenciamento no que diz respeito à cultura machista, as opressões sociais e a misoginia nas redes sociais e nos espaços públicos.

O pronunciamento feminino ganhou forças com a sanção da Lei contra o Feminicídio que tornou crime hediondo o assassinato de mulheres apenas por serem mulheres. Com isso, os meios de comunicação de massa deram bastante destaque em reportagens televisivas, na internet e em reportagens impressas sobre o movimento que denominaram de Primavera das Mulheres ou Primavera Feminista.

Um movimento que tem várias feições e foi puxado por diversas bandeiras de luta e bandeiras partidárias. $E$ todas as ações e manifestações das mulheres ganharam capa nos principais veículos de comunicação.

Foram manifestações de mulheres que ganharam as ruas de norte a sul do país contra o autor da PL 5069/2013, o deputado Eduardo Cunha. Segundo um dos movimentos que lideraram estas ações houve uma expressiva mobilização:

Foi uma primeira rodada expressiva de mais de 30 manifestações em vários cantos do país que colocou na ordem do dia um calendário de mobilizações do movimento feminista, com um novo round de atos programado para acontecer nas próximas semanas pelas diversas regiões do país (matéria publicada pelo grupo Juntas no segundo semestre de 2015) ${ }^{25}$

25 JUNTAS: a primavera feminista. Disponível em: http://esquerdasocialista.com.br/juntas-aprimavera-feminista/. Acessado em: 10 fev. 2016. 
Todo esse movimento se inicia com o aumento das tarifas de ônibus que foi o estopim que represava diversas demandas reprimidas da população brasileira. Nesse processo, a participação das mulheres foi maciça. Houve um protagonismo das mulheres jovens que desde 2014 já se organizavam, inclusive em torno da campanha para presidência da república de uma candidata que se apresentava como feminista, discutindo durante a campanha temas caros ao feminismo como o aborto, a homofobia, transfobia e violência contra mulher.

Segundo o grupo Juntas, que busca teorizar sobre a conjuntura nacional, o cenário de crise que atravessa o país impactou a vida dos trabalhadores e pesquisas lançadas em 2016 pelos órgãos oficiais, mostram como as mulheres são especialmente afetadas.

As mulheres sofrem com a maior rotatividade no mercado de trabalho, com a desigualdade salarial entre homens e mulheres, com a ocupação de cargos mais precarizados, com a dupla ou tripla jornada, que conta com o trabalho doméstico.

O impacto sobre a população do agravamento da crise econômica é sentido fortemente pelas mulheres, junto aos cortes na Educação, na Saúde, o fechamento da Secretaria de Políticas para as Mulheres e a diminuição do repasse para combater a violência contra a mulher.

E todo esse processo obteve resposta por parte do ciberativismo das mulheres, mulheres que necessariamente não pertencem a grupos organizados de mulheres, mas que tomaram iniciativas e disseminaram nas redes suas estratégias de mobilização.

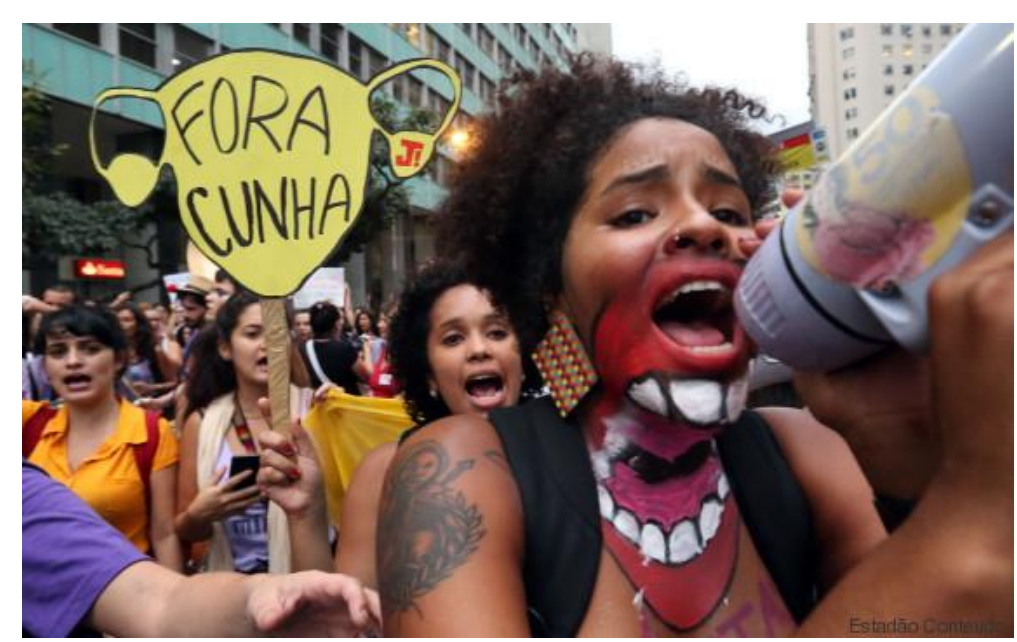

Fonte: http://esquerdasocialista.com.br/juntas-a-primavera-feminista/ 
Entre elas está o uso de hashtags, um mecanismo de indexação que possibilita agrupar postagens ou informações por palavras-chave, o que facilita a localização muito rapidamente nos mecanismos de busca da internet. São termos relevantes antecedidos do símbolo tipográfico da cerquilha (\#).

As hashtags "meu amigo secreto", "não poetize o machismo", "agora é que são elas", "chega de fiu fiu" e "meu primeiro assedio" são alguns dos exemplos de campanhas nas redes sociais que levaram milhares de mulheres a contarem sobre o machismo que sofreram e sofrem, como na fala de duas militantes:

1) Dos atos das Mulheres contra Cunha, o que ficou pra mim foi o som: milhares de mulheres. A coisa mais forte. Mais potente que eu já ouvi. Da onda de relatos do \#meuprimeiroassedio, também. Vozes femininas caladas se pronunciado, contando segredos. (Fonte: Brasil de Fato, por Norma

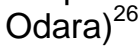

2) Acredito que toda e qualquer inciativa que permita que as mulheres se sintam seguras para falar, expor, desvendar seus medos, dores e violências significa a construção de mais um degrau para a uma sociedade onde as relações sejam sustentáveis e saudáveis. Não é saudável sentir medo de falar, de caminhar após as $22 \mathrm{~h}$ da noite, de usar o transporte público, carregar culpas e culpas nas costas que nem são nossas. E a partir da fala, da expressão, seja nós em um texto, em uma fotografia, em uma tela de pintura ou num desabafo de três linhas no Facebook, começamos a construir novas formas de valorizar nossas histórias e como as traçaremos daqui em diante.

Se traçarmos um paralelismo, as hashtags são uma forma de aglutinar pessoas e ações a partir de uma palavra geradora, como nos círculos de cultura freireanos. As mulheres de forma autônoma se organizam para que muitas façam seu pronunciamento em torno de temas relevantes sobre os quais todas se identifiquem, façam parte do seu cotidiano e propiciem um dizer de si que repercuta de forma intensa na sociedade. Revelando desta forma, uma micropolítica que o movimento de mulheres aprendeu a fazer a partir de uma construção coletiva.

Pensando nesse movimento, nós educadores precisamos rever nossas relações nas situações educativas, a construção das possibilidades de mecanismos didático-pedagógicos que possibilitem a autoria, o pronunciamento e a discussão da identidade humana na perspectiva de multiplicidades que vibram e desejam. 0 desejo precisa retomar seu lugar para que as aprendizagens façam sentido, signifiquem e sejam propulsoras de mudanças. Para isso, mais pesquisadores

${ }^{26}$ Disponível em: https://observatoriosc.wordpress.com/2016/01/06/2015-a-primavera-das-mulheresque-floresceu/. Acessado em: 22 fev. 2015. 
precisam se debruçar sobre as tecnologias que facilitam e promovem a interação, o universo dos hipertextos hoje tão dominado por profissionais que entendem de informação e transmissão de dados, mas que não trabalham com as possibilidades educacionais de ferramentas que permitem a autoria, a criação e escrita de si. 


\section{REFERÊNCIAS BIBLIOGRÁFICAS}

BAIRON, Sérgio. Hipermídia. São Paulo: Global, 2012.

BAKHTIN, Mikhail M. Questões de Literatura e Estética: a teoria do romance. São Paulo: Hucitec/UNESP, 1993.

BAKHTIN, Mikhail M. Estética da criação verbal. São Paulo: Martins Fontes, 2003. Problemas da poética de Dostoiévski. 2. ed. Rio de Janeiro: Forense, 1997.

BAKHTIN, Mikhail M.; VOLOSHINOV, Valentin. N. Marxismo e Filosofia da Linguagem: problemas fundamentais do método sociológico nas ciências da linguagem. 11. ed. São Paulo: Hucitec, 2010.

A interação verbal. In: BAKHTIN, Mikhail M.; VOLOSHINOV, Valentin. N. Marxismo e Filosofia da Linguagem. Trad. Michel Lahud e Yara Frateschi Veira. 10. ed. São Paulo, Hucitec, 2009.

BAKHTIN, Mikhail M. Problemas da poética de Dostoiévski. Trad. Paulo Bezerra. 4. ed. Rio de Janeiro: Forense Universitária, 2008.

BAKHTIN, Mikhail M. Marxismo e filosofia da linguagem. São Paulo: Hucitec. 2010.

Estética da criação verbal. São Paulo: Martins Fontes, 2010a.

BAKHTINE, MiKhaïl. Pour une philosophie de l'acte. Trad. Ghislaine Capogna Bardet. Lausanne, Editions l'Age d'Homme, 2003a.

BARTHES, Roland. 0 grau zero da escritura. 3. ed. Trad. Heloysa de Lima Dantas, Anne Arnichand e Álvaro Lorencini. São Paulo: Cultrix, 1986.

Perspectiva, 1988.

O prazer do texto. Trad. de J. Guinsburg. São Paulo: Editora

BRAIT, Beth (Org). Bakhtin e o Círculo. São Paulo: Contexto, 2009.

. Bakhtin: Dialogismo e Polifonia. São Paulo: Contexto, 2009.

BRAIT, Beth. Análise e teoria do discurso. In: Brait, Beth (Org.). Bakhtin: outros conceitos-chave. São Paulo: Contexto. 2006.

BRASIL, Ministério da Educação. Lei no 9.394/1996: Lei de Diretrizes e Bases da Educação Nacional. 20 de dezembro de 1996. Disponível em:

http://www.planalto.gov.br/ccivil 03/leis/L9394.htm. Acessado em: 06 mar. 2016. 
BRASÍLIA. Instituto de Pesquisa Econômica Aplicada. Objetivos de

Desenvolvimento do Milênio - Relatório nacional de acompanhamento. Brasília, DF: Ipea, 2004.

Secretaria de Políticas para as Mulheres Presidência da República.

Texto-base. 4ª Conferência Nacional de Política para as Mulheres. Junho de 2015. Disponível em:

http://webcache.googleusercontent.com/search?q=cache:agmo3xUeuOYJ:www.spm gov.br/4a-conferencia-nacional-de-politicas-para-as-mulheres/4a-cnpm-texto-baseversao-integral.doc+\&cd=1\&hl=pt-BR\&ct=clnk\&gl=br. Acessado em: 07 mar. 2016.

CARDARELLO, Carla Giovanna Lamas. Pedagogia Freireana: liberdade e ensaio. 2005. 165 folhas. Tese (Doutorado) - Universidade Federal do Rio Grande do Sul, Porto Alegre (RS), 2005.

CHARTIER, Roger. A aventura do livro: do leitor ao navegador. Trad. Reginaldo Carmello Corrêa de Moraes. São Paulo: UNESP/Imprensa Oficial SP, 1998.

CORREIA. Claudio Manoel de Carvalho Correia. Fundamentos da Semiótica Peircena. PUC-SP. Disponível em:

http://www.filologia.org.br/ixfelin/trabalhos/pdf/38.pdf. Acessado em: 07 mar. 2016.

DELEUZE, Gilles. Foucault. São Paulo: Brasiliense, 1988.

Espinosa: filosofia da prática. São Paulo: Escuta, 2002.

DELEUZE, Gilles; GUATTARI, Félix. Mil Platôs. Capitalismo e esquizofrenia. V.3 Trad. Aurélio Guerra Neto e Celia Pinto Costa. Rio de Janeiro: Ed. 34, 1996.

de Janeiro: Ed 34, 2012.

Mil Platôs. Capitalismo e esquizofrenia. V. 4. Trad. Suely Rolnik. Rio . O Anti-Édipo: capitalismo e esquizofrenia. V. 1. Trad. de Luiz B. L. Orlandi. São Paulo: Ed. 34, 2010.

FARACO, Carlos Alberto. Uma introdução a Bakhtin. Curitiba, PR: Hatier, 1988.

Por uma pedagogia da variação linguística. In: CORREA, Djane A. (Org.). A relevância social da Linguística: linguagem, teoria e ensino. São Paulo, Parábola Editorial; Ponta Grossa (PR), UEPG, 2007.

FEM - FÓRUM ECONÔMICO MUNDIAL. Empoderamento de mulheres: avaliação das disparidades globais de gênero. Trad./Ed. José Humberto Fagundes. Genebra, 2005.

FLEURI, R. M. A Questão do Conhecimento na Educação Popular. Ijuí, RS: Ed. UNIJUÍ, 2002.

FONSECA, Tania Mara Galli; KIRST, Patrícia Gomes. Cartografia e devires: a construção do presente. Porto Alegre, RS: UFRGS, 2003. 
FREIRE, Paulo. Educação e mudança. Rio de Janeiro: Paz e Terra, 1979.

. Conscientização: teoria e prática da libertação - uma introdução ao pensamento de Paulo Freire. 3 ed. São Paulo: Moraes, 1984.

. Pedagogia do oprimido. 27. ed. Rio de Janeiro: Paz e Terra, 1987.

. Pedagogia da esperança: um reencontro com a pedagogia do oprimido. 4. ed. Rio de Janeiro: Paz e Terra, 1992.

Pedagogia da Autonomia: saberes necessários à prática educativa. São Paulo: Paz e Terra, 1996. Olho d'Água, 2000.

Professora sim, tia não: cartas a quem ousa ensinar. 10 ed. São Paulo: 2003.

. Educação como prática da liberdade. 10. ed. Rio de Janeiro: Paz e Terra,

FREIRE, Paulo; FAUNDEZ, ANTONIO. Por uma Pedagogia da Pergunta. Rio de Janeiro: Paz e Terra, 1985 (Coleção Educação e Comunicação; v. 15).

FRIEDMANN, John. Empowerment - uma política de desenvolvimento alternativo. Celta: Oeiras, 1996.

GOHN, Maria da Glória. Novas teorias dos movimentos sociais. São Paulo: Loyola, 2008.

. Reivindicações populares urbanas. São Paulo: Cortez, 1982.

. Educação não-formal e o educador social. Revista de Ciências da Educação, Americana (SP), n. 19, p. 121-140, 2. sem. 2008.

. Movimentos Sociais e Redes de Mobilizações no Brasil contemporâneo. 1. ed. Petrópolis, RJ: Vozes, 2009.

Educação Não formal e o educador social: atuação no desenvolvimento de projetos sociais. 1. ed. São Paulo: Cortez, 2010.

. Educação não-formal e cultura política: impactos sobre o associativo do terceiro setor. 2 ed. São Paulo: Cortez, 2011.

GUATTARI, Félix. Revolução Molecular: pulsações políticas do desejo. São Paulo: Brasiliense, 1987.

Papirus, 1988.

O inconsciente maquínico: ensaios de esquizoanálise. Campinas, SP:

As três ecologias. Campinas, SP: Papirus, 1990. 
Caosmose: um novo paradigma estético. Trad. Ana Lúcia de Oliveira e Lúcia Cláudia Leão. Rio de Janeiro: Ed. 34, 1992.

GUATTARI, Félix; ROLNIK, Suely. Micropolítica: cartografias do desejo. Petrópolis, RJ: Vozes, 2013.

HARCOURT, Wendy. Cyberspace as a networking tool for feminists. Labrysestudos feministas. 2005, janeiro/julho. Disponível em:

http://www.labrys.net.br/labrys7/cyber/wendy.htm. Acessado em: 08 mar. 2016.

HERNÁNDEZ, José. O gaúcho Martín Fierro. A volta de Martín Fierro. Trad. de Ciro Correia França. Curitiba, PR: Travessa dos Editores, 2013

JAUSS, Hans Robert. O prazer estético e as Experiências Fundamentais da Poiesis, Aesthesis e Katharsis. In: LIMA, Luis (Org.). A literatura e o leitor - textos de Estética da Recepção. Rio de Janeiro: Paz e Terra, 1979.

KASTRUP, Virginia; BARROS, R. B. Movimentos-funções do dispositivo na prática da cartografia. In: PASSOS, Eduardo; KASTRUP, Virginia; ESCOSSIA, L. (Orgs.). Pistas do método da cartografia: pesquisa-intervenção e produção de subjetividade. Porto Alegre, RS: Sulina, 2009. p. 76-91.

KINCHELOE, Joe L. Introduction: the power of the Bricolage: expanding research methods.In: KINCHELOE, Joe L.; BERRY, Kathleen S. Rigour and complexity in educational research: conceptualizing the bricolage. London, Open University Press, 2004.

KINCHELOE, Joe; BERRY, Kathleen S. Pesquisa em educação: conceituando a bricolagem. Porto Alegre, RS: Artmed, 2007.

$\mathrm{KOCH}$, Ingedore G. V.. Introdução à linguística textual. São Paulo: Martins Fontes, 2005.

. Linguagem e interação. São Paulo: Contexto, 1992.

LANDOW, George. Teorías del Hipertexto. Madrid, España: Paidos, 1997.

LÉVY. Pierre. Cibercultura. São Paulo: Editora 34, 1999.

As tecnologias da inteligência. Rio de Janeiro: Editora 34, 1993.

As árvores de conhecimentos. São Paulo: Escuta, 1995

A inteligência coletiva: por uma antropologia do ciberespaço. 3. ed. São Paulo: Loyola, 2000.

O Futuro da internet: em direção a uma ciberdemocracia planetária. São

Paulo: Paulus, 2003/2010. 
LISBOA, Teresa K. O empoderamento como estratégia de inclusão das mulheres nas políticas sociais. Fazendo Gênero 8 - Corpo, Violência e Poder. Universidade Federal de Santa Catarina. Florianópolis (SC), 2008.

LISPECTOR, Clarice. Água viva. 10. ed. Rio de Janeiro: Nova Fronteira, 1980.

MACHADO, Glaucio José Couri (Org.). Educação e ciberespaço: estudos, propostas e desafios. Aracaju, SE: Virtus, 2010.

MARCUSCHI, Luiz Antônio. Produção textual, análise de gêneros e compreensão. 3. ed. São Paulo: Parábola Editorial, 2008.

MANTOVANI, Camila Maciel Campolina Alves Mantovani; MOURA, Maria Aparecida. Informação, interação e mobilidade. Inf. Inf., Londrina (PR), v. 17, n. 2, p. 55 - 76, maio/ago. 2012. Disponível em:

http://www.uel.br/revistas/uel/index.php/informacao/article/view/13764/pdf.

Acessado em: 08 mar. 2016.

MARCUZZO, Patrícia. Diálogo inconcluso: os conceitos de dialogismo e polifonia na obra de Mikhail Bakhtin. Cadernos do IL, Porto Alegre (RS), n. - 36, junho de 2008. Disponível em: http://www.seer.ufrgs.br/cadernosdois. Acessado: 22 ago. 2014.

MORSON, Gary Saul; EMERSON, Caryl. Mikhail Bakhtin: criação de uma prosaística. Trad. Antonio de Pádua Danesi. São Paulo: Editora da Universidade de São Paulo (USP), 2008.

OBJETIVOS DE DESENVOLVIMENTO DO MILÊNIO. Relatório Nacional de Acompanhamento. Brasília, DF: IPEA, 2004.

PASSOS, Eduardo; KASTRUP, Virgínia; ESCÓSSIA, Liliana (Orgs.). Pistas do método da cartografia: Pesquisa-intervenção e produção de subjetividade. Porto Alegre, RS: Sulina, 2015.

PIERCE, Charles Sanders. Semiótica. 2. Ed. São Paulo: Perspectiva, 1995.

PRADO FILHO, Kleber; TETI, Marcela Montalvão. A Cartografia como método para as ciências sociais e humanas. Barbarói, Santa Cruz do Sul (RS), n.38, p., jan./jun. 2013.

RAGO, Margareth. Feminizar é preciso. Por uma cultura filógina. Revista do SEADE, São Paulo, 2002.

. Essas mulheres: práticas feministas em novos modos de subjetivação. Dossiê Gênero organizado por Elisabeth J. Rago, 2009.

ROLNIK, Suely. Cartografia sentimental: transformações contemporâneas do desejo. Porto Alegre, RS: Sulina. Ed. UFRGS, 2007. 
SÁ, Déborah. A Feminista Perfeita. Aquela Deborah. 29 de ago. 2012. Disponível em: https://aqueladeborah.wordpress.com/2012/08/29/a-feminista-perfeita/. Acessado em: 14 jan. 2015.

SANTAELLA, Lucia. Matrizes da linguagem e do pensamento: sonora, visual, verbal. São Paulo: lluminuras, 2001.

Da cultura das mídias à cibercultura: o advento do pós-

moderno. Revista Famecos, Porto Alegre (RS), dez. 2003, p. 23-32.

Linguagens Líquidas na Era da Mobilidade. São Paulo: Paulus,

2007.

Semiótica Aplicada. São Paulo: Thomson Learning, 2007a.

Percepção: fenomenologia, ecologia, semiótica. São Paulo: Cengage,

2011.

SILVA, Carmen. O desafio das publicações feministas. Estudos Feministas, Florianópolis, 21(2): 625-635, maio-agosto/2013.

SILVESTRI, A.; BLANCK, G. Bajtín y Vigotski: la organización semiótica de la conciencia. Barcelona, España: Anthropos, 1993.

SOBRAL, Adail. Dialogismo e interação. In: SOBRAL, A. Do dialogismo ao gênero - as bases do pensamento do círculo de Bakhtin. Campinas, SP: Mercado de Letras, 2009.

SPIVAK, Gayatri C. Pode o subalterno falar? 1. ed. Trad. Sandra Regina Goulart Almeida, Marcos Pereira Feitosa e André Pereira. Belo Horizonte, MG: Editora da UFMG, 2010.

STRECK, Danilo R. Práticas educativas e movimentos sociais na América Latina: aprender nas fronteiras. Série-Estudos. Periódico do Mestrado em Educação da UCDB. Campo Grande, MS: Universidade Católica Dom Bosco, p. 99-112, jul./dez. 2006.

STRECK, Danilo R.; REDIN, Euclides; ZITKOSKI, Jaime José (Orgs.). Dicionário Paulo Freire. 2. ed. rev. e ampl. Belo Horizonte, MG: Autêntica Editora, 2010.

TARROW, Sidney. Power in Movement: Social Movements, Collective Action and Politics. Cambridge, Cambridge University Press, 1994.

TODOROV, Tzevan. Mikhail Bakhtine: le principe dialogique suivi de Écrits du cercle de Bakhtine, Paris: Seuil, 1981.

VIDON, Luciana Novaes. Subjetividade e dessubjetivação em textos dissertativosargumentativos. IN: VIDON, L. N.; LINS, M. da P. P. (Orgs.). Da análise descritiva aos estudos sobre texto e discurso: a linguística no Espírito Santo. Vitória, ES: PPGEL/UFES, 2009. 
VIGOTSKY, Lev Semenovich. Pensamento e linguagem. 3. ed. São Paulo: Martins Fontes, 2005.

VOLOSHINOV, V. N. La construcción de la enunciación. In: SILVESTRI, A.; BLANCK, G. Bajtín y Vigotski: la organización semiótica de la conciencia. Barcelona, España: Anthropos, 1993. Le struture de l'énoncé [A estrutura do enunciado]. Trad. para uso didático de Ana Vaz. In: TODOROV, T. Mikhail Bakhtine: le principe dialogique suivi de Écrits du cercle de Bakhtine, Paris: Seuil, 1981.

VOLOSHINOV, V. N.; BAKHTIN, M. M. O discurso na vida e o discurso na arte. Sobre poética sociológica. Trad. Carlos Alberto Faraco e Cristovão Tezza, para fins didáticos. s/d.

WARAT, Luis Alberto. Vida e obra de Felix Guattari. É difícil dizer adeus: do antiédipo à ecosofia. Revista Sequência, V. 13, n. 25, Curso de Pós Graduação em Direito - UFSC, Dezembro de 1992, p. 79-83. 
ANEXOS 


\section{Anexo 1 - Carta aos pais da autora de Sapatilhando}

Painho e Mainha,

Eu não sei nem como começar esta carta...da mesma maneira que eu não soube começá-la outras tantas vezes que sentei para tentar escrevê-la.

Primeiro de tudo, eu lhes devo desculpas. Desculpas por não ter tido força de ter lhes falado antes sobre tudo. Desculpas por ter passado por tanto, tanto sofrimento sem Ihes comunicar.

Na minha cabeça eu estava lhes protegendo do sofrimento que eu sei que lhes causaria... mas talvez tenhamos todos nós sofrido mais ainda assim. Sei que, depois de ter 'jogado' tudo isso em cima de vocês, eu lhes devo uma explicação. Não sei se conseguirei dá-la, não sei se vocês estarão abertos a ouvi-la, mas de qualquer forma, tentarei Ihes falar sobre o assunto.

Faz muito, muito tempo que sofro. Que grito dentro de mim mesma. Passei muito tempo negando que eu pudesse ser lésbica. Sei das implicações religiosas disso, claro que sei. Sei o que a igreja, em sua maioria, fala. E, embora mamãe ache que não, eu TAMBÉM sou católica. Então sofri muito tempo sozinha. Sem ousar de forma alguma expressar de alguma maneira o que se passava dentro de mim.

Foram anos e anos me sentindo uma "ET". Me sentindo diferente de tudo e todos. Sem saber qual era o meu lugar no mundo. Sem entender porque eu sentia tudo o que sentia. Tentei namorar garotos. Tentei gostar deles. Tentei até me imaginar ao lado de um para o resto da vida - razão pela qual eu disse "sim" ao (nome do noivo). Mas não dava. Não importava o que eu fizesse, ou o quanto o cara fizesse por mim, eu sentia que não estava feliz. Que não era aquilo que eu queria, que não era quem eu era.

No entanto, sempre que o pensamento chegava na minha cabeça, tímido, assustado, eu o repelia o mais forte que eu podia. Eu sei de quem eu sou filha, eu sei como pensam meus pais. E, acima de tudo, eu não me imaginava jamais lhes trazendo tanta dor e sofrimento. Por muito tempo neguei qualquer pensamento meu, por muito tempo fui uma pessoa assexuada até, por medo de ferir vocês, por medo de perder vocês dois.

Quando eu e o (nome do noivo) terminamos, eu sabia que eu poderia tê-lo de volta. Eu sabia que tudo o que eu precisava fazer era pedir desculpas para ele. Eu sabia que ele era incrivelmente apaixonado por mim. Mas eu não podia fazer isso. Eu sabia que se eu voltasse para ele, eu só iria trazer desgraça para a minha vida e para a dele, porque eu já sabia quem eu era. Eu já sabia o que eu queria e, por mais assustador que fosse, eu sabia que não podia mais mentir para mim.

Então fiz um pacto comigo mesma. 'Casei comigo mesma'. Decidi que seria sozinha. Que se eu não podia ficar com mulheres, já que isso partiria vocês dois no meio, já que isso lhes traria tanta dor e desgosto e vergonha, eu decidi que então iria construir a minha vida só. Não seria uma vida tão ruim: eu teria meus títulos de mestre e doutora, eu teria minhas aulas, meus alunos e, um dia, livros e filhos adotivos ou não. Tinha sido essa a minha decisão.

Mas eu não consegui mantê-la. Não dá para descrever aqui para vocês, agora, tão longe já de tudo o que passei, o tanto de conflitos que vivi. O tanto de lágrimas que chorei escondida. As vezes que achei que seria melhor deixar de existir a ser 
fonte de tanto desgosto e vergonha para vocês. Mas tudo isso não estava dando certo; eu não queria me matar. Eu queria viver. Eu amo estar viva. Eu amo a vida.

Mas eu não estava vivendo. Eu tinha pausado a minha vida por medo de seguir adiante. Por medo do sofrimento que eu iria lhes causar. Mas eu estava extremamente infeliz! Eu não via muito sentido nas coisas, não se eu sequer podia olhar no espelho e saber que eu estava sendo verdadeira comigo mesma.

Aí entrei no mestrado em Psicologia. Tudo veio como um turbilhão em mim. Entender mais sobre a Psicologia, conhecer casos como o meu, conversar com Psicólogos... foi um período de transformação interna gigantesco!!

Vocês não têm noção disso, eu sei. Eu nunca dividi isso com vocês. E sei que isso não foi a maneira ideal... mas eu temia exatamente o que aconteceu hoje. $\mathrm{E}$, embora a verdade já esteja prevalecendo, o temor de perder vocês ainda continua...

Mas toda essa minha luta interna por que passei está registrada na minha dissertação de mestrado. Da dedicatória a vocês:

$\mathrm{Na}$ disciplina de Estética, ainda na graduação de Jornalismo, o Prof. Dr. (nome do professor) pediu um dia que nós, seus alunos, trouxéssemos para a aula algo que fosse para nós uma representação da beleza.

Eu levei uma foto dos meus pais.

Agora, já no mestrado em Psicologia, é mais uma vez a imagem deles que me vem à mente quando penso em beleza.

Dedico este estudo a essa beleza que eles despertam em meus olhos.

A meus pais: esses dois seres de tantas palavras, de tantos silêncios e de tantos momentos. A esses dois seres que são para mim, lugar. Pausa. Referência. Origem. Lar.

A eles, que têm que lidar sempre com o que eu sou e com o que eu deixo de ser. Que amam tão generosamente que sonham para mim sonhos que sequer são meus. Que se entregam a tal ponto que sequer sabem direito onde eles terminam e onde eu começo. Que querem tanto cuidar que teimam em fazer de meus espaços, seus espaços.

A meus pais: por toda a graciosidade e encantadora confusão que seu amor gigante me traz.

A eles o meu amor mais fiel e a minha gratidão por representarem tudo o que representam.

Às conclusões que dei à minha pesquisa:

Pergunto-me se encontrar o seu 'canto no mundo' na verdade é encontrar não o canto que the deixe ser a versão mais forte de si; mas sim um canto que lhe deixe ser a versão mais frágil de si. Concluo então que um lar é na verdade uma casa-caracol: um lugar que abrace o seu corpo no formato mais mole e vulnerável que ele possa ter.

$\mathrm{E}$, ao concluir isso, eu tive a certeza de que tinha que ir embora de (nome da minha cidade natal). Me desculpem, em momento algum quis isso como uma forma de descontar algo em vocês, ou de puni-los por algo ou de Ihes trair. Eu quis Ihes proteger. Eu sabia que eu não podia forçar vocês a me entender, a me aceitar, então o caminho que via à minha frente era o de construir o meu próprio lar, aonde eu pudesse ser quem eu sou, aonde eu tivesse a liberdade de não me sentir tão condenada por estar sendo eu mesma. 
Esta história está toda fragmentada, eu sei, mas minha cabeça está estourando, meu coração está em pedaços, e só de imaginar o tanto que vocês estão sofrendo agora, por minha causa, eu fico sem terra nos pés.

Mas se vocês um dia lerem a minha dissertação de mestrado, vocês vão ver muitos desses meus conflitos e sofrimentos lá registrados. No meio do mestrado, eu ainda lutava muito com tudo isso que estava acontecendo dentro de mim. Foi aí que veio a certeza incontestável: eu me apaixonei por uma colega da especialização. Vocês não chegaram a conhecê-la, mas você, mãe, já ouviu sobre ela. Era a (nome da amiga), que trabalhava na Folha de São Paulo. Não posso lhes descrever o que eu sofri. Eu não tinha mesmo mais como esconder isso tudo de mim mesma, eu não tinha mais como mentir, eu não conseguia enterrar dentro de mim o que eu sentia por ela. E era algo que eu nunca, nunca havia sentido antes. Eu nunca fui atrás de namorado algum! Todos eles que vieram até mim! $E$ eu namores com eles mas nunca dei valor a nenhum! $\mathrm{E}$ todos eles eram homens bem legais! Eram bons seres humanos! Eu não tenho trauma nenhum de homem! Apenas nunca os quis. Nunca fiz questão deles. Mas quando eu conheci a (nome da amiga), tudo fez sentido e foi maravilhoso e horrendo ao mesmo tempo! Eu nunca senti tanto medo na minha vida! (A não ser quando, depois, eu vim para São Paulo). E eu sabia que estava sozinha. $O$ que quer que eu sentisse, o que quer que doesse, eu não podia conversar com ninguém! Foi num desses dias que você, mãe, me pediu para eu lhe deixar no grupo de oração e eu fui chorando... Você me pediu para que eu conversasse com você, para que eu lhe falasse o que quer que estivesse me afligindo... mas como? Como eu poderia falar? Eu sabia que seria como lhe tacar uma facada no peito! Então, mais uma vez me calei...

Algum tempo depois disso, quando a situação estava insuportável, até porque a (nome da amiga) nunca ficou sabendo do que eu sentia por ela, já que ela morava com o namorado e era apaixonada por ele, surgiu a oportunidade de viajar para a Itália - o meu trabalho havia sido aceito no congresso e vocês, como vocês sempre fizeram, toparam o sacrifício (grande, eu sei!) de pagar pela minha viagem. Eu juro, se eu não tivesse viajado nessa época, eu teria enlouquecido!! Eu estava sofrendo muito por tudo o que eu sentia pela (nome da amiga). Viajei.

Nessa viagem, visitei muitas igrejas. Pedi muito a Deus que me ajudasse. Eu já vinha lendo muito sobre Deus, sobre Teologia, sobre Fé para conseguir lidar com o que quer que Deus pensasse sobre mim. Chorei muito para Ele. Conversei muito com Ele. E, aos poucos, Ele foi me dando Sua Paz. Ele foi me falando da Sua Misericórdia. Ele foi me dizendo sobre a Sua Benevolência. Ele me explicou muito sobre a diferença do amor Dele e do amor dos homens. E ele me disse de várias formas - em sonhos, em passagens, em textos, em anjos que Ele colocou no meu caminho... - que ele era meu Pai, e que ele me amava exatamente como eu sou. Essa certeza me fortaleceu e, acreditem, eu tive a Deus e tenho a Deus ao meu lado sempre.

Ao longo da viagem à Itália, eu consegui alguma paz. Eu decidi que iria seguir adiante com a minha vida, iria atrás da minha felicidade, iria me aceitar como eu sou e fazer as pazes comigo mesma.

Assim que cheguei, fiz um blog (que é uma espécie de página na internet aonde podemos colocar textos, imagens etc). O dia está lá marcado: 27 de outubro de 2008. Já que não tinha com quem conversar, comecei a escrever textos nesse blog sobre um pseudônimo que escolhi. Por eu escrever relativamente bem, logo eu (ou a "Helena", apelido que me dei) fiquei relativamente famosa na internet. Muitas 
meninas vieram receber forças no que eu escrevia para dar força a mim. Lá eu depositava meus sofrimentos e reflexões e elas se identificavam com isso. Ao me ajudar, acabei ajudando muitas outras. Nesse um ano de blog, o resultado é um livro que estou escrevendo sobre Homossexualidade e Família. E só não fui adiante com muitas outras coisas mais, porque vocês ainda não sabiam de mim.

Quando minha mãe viajou para a Itália, um nó se formou em mim. Cada vez que eu lhe via, mãe, seguindo não a parte mais humana da igreja, mas seguindo a parte mais extrema da igreja, eu me sentia mais e mais lhe perdendo. Eu sabia que mais e mais você iria me condenar, iria me sentenciar ao inferno, mesmo que em todos os outros aspectos da minha vida eu fosse uma pessoa exemplar.

Quando você chegou de viagem, meu pai estava tão feliz!! Queria que fôssemos todos nós lhe pegar no aeroporto! $\mathrm{E}$, por mais que eu quisesse, por mais saudades que eu tinha sentido de você, eu não consegui ir. Inventei uma desculpa para o papai e, ao prantos, escrevi a carta abaixo (por favor não tenha raiva, a escrevi no meio do meu desespero):

\section{SEXTA-FEIRA, 7 DE NOVEMBRO DE 2008}

\section{| carta à mãe |}

Minha mãe, daqui a pouco irei Ihe buscar no aeroporto.

Foi uma viagem linda a que você fez, eu sei.

Ouvir sua voz no telefone contando do presente que estava sendo essa viagem foi absolutamente delicioso.

E eu fico aqui a pensar em você. Você super mãe. Você mulher que abriu mão de tanto para ser filha, irmã, profissional, esposa e mãe. E eu tenho orgulho de você.

Confesso que durante muito tempo eu me perguntei, como única filha mulher da sua prole, porque eu não podia conversar com você sobre dúvidas do meu corpo que mudava, ou do que eu sentia, ou sobre o que eu começava a querer sentir...

Mas o tempo foi passando e eu fui percebendo que dentro da sua noção de religiosidade, certas coisas não podem ser discutidas. Não cabem à relação de pai e filho, de mãe e filha. Sexo não é algo que se discuta. Mulher tem que ser séria. Tem que cuidar da sua imagem, da sua moral...

$\mathrm{E}$ eu, sempre muito reflexiva, acabei tirando minhas próprias conclusões sobre muita coisa. Acabei criando 'coro grosso' e enfrentando o mundo de peito aberto.

Acabei colocando saltos altos, resgatando todos os príncipes que surgiram no meu caminho, agarrando-os pela cintura e pulando em cima do cavalo branco sem sequer me despentear.

No meio do caminho, nos anos que vão passando, eu passei muito tempo conversando comigo mesma, lendo livros, assistindo e dando aulas, aprendendo culturas e idiomas e sendo aluna de todos os que eu reconhecesse como professor.

No meio de tantos diálogos, como não poderia deixar de ser, eu acabei escutando a mim mesma.

E decidi usar meu 'coro grosso' para me respeitar, para assumir a alma que eu carrego no corpo, para gostar de minha própria beleza.

Você não sabe disso.

Sua princesa jamais poderia gostar de mulheres.

Esse seria o pecado máximo. A ironia máxima. 
E eu confesso que, no meio de todo o caos e angústia, ainda consigo rir da ironia que é tudo: Sua filha perfeita carrega o que seria, para você, a pior imperfeição.

Desculpe... Choro.

Choro porque the amo.

E sei da dor que tudo lhe causaria.

E choro porque tantos já sabem e você não.

Você não sabe quem é sua filha. Se eu fosse mãe, essa para mim seria a pior tristeza.

E é louco para mim o fato de que eu falo para um auditório de duzentas pessoas sem nem suar a camisa, e dou aula para cinqüenta alunos, e enfrento uma entrevista de trabalho conseguindo manter a pose de que sou a melhor candidata possível a ser escolhida e abro minha boca para apresentar trabalhos em inglês, e trabalho de intérprete... e-não-consigoenfrentar-você.

Você, tão pequenina diante de mim com seus um metro e sessenta de altura.

E quando saímos juntas e você me apresenta para suas amigas, eu vejo no seu rosto a felicidade e o orgulho diante do "Mas como sua filha é bonita! E doce!".

E eu olho para você com pena, com pena de você se contentar com tão pouco.

E cá estou eu. À beira dos meus trinta anos, alguns anos vividos no estrangeiro, com especialização e mestrado nas costas, quase a sair de casa definitivamente, e ainda sinto-me uma covarde.

Covarde por não conseguir testar o seu amor incondicional de mãe.

E não é medo de você não me aceitar como eu sou.

É medo da dor que the trarei. Medo de desconstruir seu mundo.

Medo de matar sua filha perfeita.

E então tenho raiva de mim.

Por não tentar lhe transformar. Por não tentar abrir seus olhos.

Por não tentar fazê-la ver que o mundo é tão mais do que o que a sua religião prega.

Deus é incrível, mãe.

Eu sei. Converso com Ele. Estudo sobre Ele.

Leio muitos livros. Dialogo com pessoas que escreveram sobre essências.

Algo muito além da casca que é o corpo de cada um de nós.

E tenho certo despeito, como filha Dele, de ver você e seus religiosos $O$ espremerem para que Ele caiba em sua interpretação humana.

Ele não cabe no que vocês entendem. E Ele não cabe no que vocês não entendem.

Ele é maior que tudo. E por isso, com o aval Dele eu sequer me preocupo. É Ele quem ainda me faz cafuné e me carrega nos braços. E Ele sorri doce para mim dizendo: "Perdoa. Eles não sabem o que fazem".

E eu perdôo, claro.

Acho que na dor a gente aprende a perdoar.

Até para que a dor seja aliviada.

Mas às vezes eu penso, mãe: se eu morrer amanhã, você não terá conhecido o melhor de mim.

Você me acha forte, mãe? Realmente sou. Você não sabe nem a metade.

Você não sabe de tantas alegrias e tristezas que eu já tive.

Você não sabe do tanto que eu já tive que enfrentar sozinha.

Você não sabe que naquele dia eu gritava em prantos por dentro enquanto ia Ihe deixar no seu grupo de oração. E o quanto eu lhe precisava. 
Você me acha bonita, mãe? Sou mesmo.

Mas vou além dessa beleza que um dia sumirá.

A minha beleza é de alma, é de espírito. É de saber ver além de nomes inventados por nós: "homem" e "mulher" são substantivos, mãe. Ninguém ama substantivo. O que se ama é o que não-tem-nome. $E$ eu me sinto superior por conseguir amar o que não tem nome. Porque sei que posso ver, enquanto tantos são míopes e cegos.

E eu sei que chegará o dia em que eu terei que olhar nos seus olhos e the dizer: Mãe, eu preciso que você me ame além do que o que você acha certo. Eu sou sua filha, e eu mereço isso.

Até lá, mãe, desculpe, mas eu lhe dou apenas metade de mim.

E você é minha mãe, e não merece isso.

Sobre ser quem eu sou, como eu sou, acreditem, eu não tenho culpa! Vocês não têm culpa! Cada vez mais está provado que é uma característica biológica! Como é ser alto ou baixo! Se eu tivesse opção, se isso fosse uma escolha, por que eu iria escolhê-la!! É um caminho sofrido demais! Para mim e para vocês!! Não, eu não tenho culpa. Mas hoje sei que é quem eu sou e já fiz as minhas pazes com isso. Só espero que o tempo faça o mesmo com vocês, porque eu não sei se quero estar em um mundo em que eu não possa ter vocês perto de mim.

$E$ se isso foi tão difícil para mim, se eu nunca tive a coragem de lhes contar, foi por medo de perder vocês dois.

Sei que estou colocando o peso do mundo inteiro nas suas costas, eu sei. Carrego esse peso já há muito tempo. Mas, pelo menos agora vocês sabem de mim. E agora vocês podem tentar me amar por quem eu sou de verdade, não por quem vocês acham que sou.

Entendo que vocês talvez precisem de um tempo, que vocês talvez queiram distância de mim por enquanto... Não tem problema. Eu já estava me preparando para isso. Enquanto não pudermos estar próximos novamente, vou me alimentando das tantas e tantas e incontáveis demonstrações de amor que vocês já me deram! Não pensem que não sei. Eu sei o tanto de sacrifícios que vocês já fizeram por mim! Eu sei dos tantos e tantos momentos em que eu me senti tão amada e protegida por ter vocês dois como meus pais!

Me desculpem estar Ihes causando tanta dor e decepção!! Isso era a última coisa que eu queria!!

Eu sei que vocês se sentem traídos porque eu contei para outras pessoas antes de vocês, mas por favor não se sintam! Essas pessoas foram anjos que me ajudaram tantas vezes! Me acolheram e me deram colo e me disseram a frase que eu mais precisava ouvir: "Que tudo daria certo no final." Essas pessoas me abraçaram nas tantas vezes em que eu precisei de um abraço.

Lembra que você um dia, mãe, brigou comigo porque eu cheguei em casa falando coisas boas da (nome da mãe da amiga), a mãe da (nome da amiga)? Mas eu cheguei assim, mãe, porque a (nome da amiga) também é lésbica e a mãe dela, depois de passar por um período de dor, aceitou a filha dela. A (nome da mãe da amiga) me disse: "Helena, não vou dizer que não foi difícil. Foi. A gente tem filho e tem mil planos pra eles. Aí eles vão ficando grandes e, claro, eles mesmos fazem seus planos e a gente sente uma porrada atrás da outra. No começo pensei na minha família, no que iam dizer, na sociedade.. foi uma guerra aqui em casa. Chamei ela de sem-vergonha, de desajuizada, de ridícula...disse que não era mais minha filha. E fomos nos distanciando cada vez mais. Ela chegava em casa e ia 
direto para o quarto dela. Eu estava perdendo a minha filha e não sabia mais o que fazer. Até que um dia a ouvi chorando no quarto. Aos prantos. Aí me toquei de qual era a promessa que eu tinha feito para ela quando ela nasceu: a de que iria estar sempre do lado dela, a de que tentaria sempre protegê-la, a de que sempre Ihe ofereceria o meu colo. Foi aí que entrei no quarto dela e a abracei. E passamos muito tempo assim. Depois disso, passei a ler mais sobre a homossexualidade, entendi que não é doença ou escolha. Resgatei minha filha para mim. Percebi que o mundo, por ser tão preconceituoso e limitado, vai Ihe machucar demais já. $E$ eu jamais seria uma dessas pessoas. Quando apedrejarem a minha filha, eu estarei aqui, protegendo-a, não ajudando os que estão atirando pedras."

E eu voltei para casa naquele dia querendo apenas deitar no colo de vocês dois, como fiz tantas vezes quando era pequena. Mas não tive coragem.

Tive duas namoradas aí em (nome da minha cidade natal). Vocês não as conheceram. Foram mulheres que conheci na internet. Uma delas meio doidinha, a outra uma pessoa de um coração lindo. Mas eu não sentia amor por elas, eu queria apenas consolidar minhas certezas. $\mathrm{E}$ com certeza tive mais certeza do que nunca de quem eu sou. A ida para São Paulo soava como um grito de liberdade, finalmente poderia ser eu mesma.

Pouco antes de vir para São Paulo conheci a (nome da minha esposa). Sim, estamos juntas. Me perdoem por tanta porrada de uma vez só. Mas eu não tinha como contar para vocês. Tentei várias vezes. Quando tudo deu errado em São Paulo, fiz o que o meu coração mandava e vim para (nome da cidade em que moro hoje). Sei que vocês não conhecem a (nome da minha esposa), e isso é uma preocupação a mais para vocês, mas ela é feminina como eu, ela tem uma ótima cabeça sobre os ombros e um coração lindo. Tem me dado muita força ao longo desses meses. Os pais dela sabem de mim e me aceitam como parte da família. Sabem dela também e lidam bem com isso. A avó dela também sabe e nunca me tratou mal por isso, quando ela dá alguma alfinetada é por ciúme da (nome da minha esposa). Por saber que a (nome da minha esposa) me ama tanto e o quão importante eu sou para ela.

Quando fui para (nome da minha cidade natal) em Julho, eu quis mais do que nunca contar para vocês. Acabar com essa farsa. Eu estava muito mal - tanto que isso estava estampado na minha pele. Foram muitas e muitas as vezes - para não dizer todas - em que depois da gente se falar no telefone eu ficava mal, eu chorava. A cada "Nós também te amamos" de vocês eu pensava "Será que me amariam se soubessem quem eu sou?". Aí em (nome da minha cidade natal) tudo piorou. A felicidade de ver vocês, de estar perto de vocês se misturava à angústia de não estar sendo verdadeira. E a cada abraço que dávamos eu tinha vontade de chorar, achando que eu não estaria sendo abraçada se vocês soubessem de mim. E eu ia contar, mas aí, quando fomos para aquele sushi e aqueles homens se comportaram de forma tão inadequada, e quando chegamos em casa vocês dois comentaram que absurdo que era, eu desisti. Chorei até dormir naquele dia.

E quando chegou o dia de ir embora, eu lhes dei tchau sabendo que talvez a próxima vez que eu viesse a (nome da minha cidade natal) eu não seriam bem vinda. Chorei a viagem toda. Graças a Deus ele colocou a (nome da minha esposa) na minha vida! Senão nem sei o que eu teria feito de tão "abandonada" que estava me sentindo quando cheguei. 
Minhas amigas - (nomes das minhas amigas) - me deram muita força em todos esses meses. Sei que sequer dei a vocês dois a chance de estarem ao meu lado, mas é que o medo de perder vocês era maior do que tudo.

Me desculpem.

Entendo o desgosto que acabei de me tornar para vocês. Sei que vocês desconstruíram a imagem que tinham de mim. Sei que estão sem chão nos pés no momento. E juro que entenderei se não for possível vocês me aceitarem. Sofrerei muito, demais. Mas entenderei porque sei que não é fácil. Eu fui muito, muito amada por vocês sempre. Amada por uma vida inteira.

Apenas saibam o quanto eu amo vocês. $O$ quanto eu preciso de vocês. $O$ quanto vocês são importantes para mim. E o quanto eu quero vocês ao meu lado.

Eu sou a filha de vocês - nada vai mudar nunca isso. E eu continuo sendo a mesma pessoa, com as mesmas morais e ideologias. Com a mesma seriedade e meiguice. Sou a mesma - tanto que vocês convivem com isso há mais de dois anos sem saber. Apenas hoje sou uma pessoa feliz. $E$ isso se vê até no meu corpo, na minha personalidade, no meu bem-estar. E, acreditem, estou mais próxima de Deus do que nunca! Sem Ele eu não seria nada! Sem Ele eu já teria ido embora desse mundo que entende tão pouco sobre tudo! Sem Ele nada faria sentido! Até porque Ele está em tudo e eu consigo reconhecer isso: da rosa amarela, ao canto do pássaro à mudança no coração das pessoas.

Eu amo muito vocês, painho e mainha.

E me perdoem por ser justamente eu a destruir o mundo de vocês.

Isso me corrói por dentro. vocês.

Só Deus é testemunha de como estou aqui sofrendo a dor gigante que infligi a

Saibam que respeitarei qualquer decisão que tomem. E, por favor, não me mandem mais dinheiro. Não quero que, ainda por cima, vocês tenham que fazer isso. Há muito já queria ter Ihe livrado dessa responsabilidade, mas não tinha argumentos para fazê-lo. Não se preocupem, eu me viro. 


\section{Anexo 2 - Contando como andam os estudos do Sapatilhando (E-mail)}

\section{Contando como andam os estudos do Sapatilhando}

7 mensagens

Rita Sousa <ritasousa122@gmail.com> 4 de maio de 2014 20:57

Para: Helena Paix <helenapaix@gmail.com>

Olá Helena,

entre espaços e tempos se produzem as certezas e inseguranças de quem tenta cartografar um narrar de si como o seu.

Estou desde 2012 no firme propósito de cartografar seu trabalho no blog Sapatilhando. Creio que em junho qualifico o projeto de tese. Digo creio porque estou mergulhada em leituras e mais leituras que me possibilitem entender o dadas com Guattari, Bakhtin e mais alguns iluminados para dar conta da riqueza desta produção.

Sei que estou longe das redes faz um tempinho, porque precisei ficar atenta e inquieta para este estudo.

Espero que no momento certo, eu possa ouvir a autora desse trabalho. Uma escuta sensível e que continue me transformando como assim o fez desde o primeiro momento que tive contato com a dona das sapatilhas.

um abraço carinhoso

\section{Sempre grata}

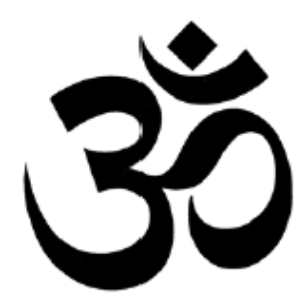

MSc Rita de Cácia V M de Sousa

Doutoranda em Educação pela Universidade de BrasíliaUnB

Coordenadora de Educação a Distância da EGOV/DF

Pesquisadora do CNPQ/ GRUPPEUnB

Docente Universitária 
Contatos: $85532124 / 33440091$

Helena <helenapaix@gmail.com> 26 de junho de 2014 00:09

Para: Rita Sousa <ritasousa122@gmail.com>

Oi, Rita! Que bom ouvir de você!

Desculpe a demora, só vi seu email agora! Eu e minha esposa adotamos duas crianças e com a chegada dos filhos tenho andado afastada também!

Mas, como já te disse antes, pode contar comigo!

Bjos,

Helena.

| Nós nos tornamos mais autênticos quanto mais nos parecemos com o que sonhamos que somos |

Almodóvar

07/03/2016

Gmail - Contando como andam os estudos do Sapatilhando

https://mail.google.com/mail/u/0/?ui=2\&ik=05c19f7fd0\&view=pt\&q=helenapaix\%40gmail.com\&qs=true \&search=query\&th $=1$

$\sim$ http://sapatilhando.blogspot.com/

[Texto das mensagens anteriores oculto]

Rita Sousa <ritasousa122@gmail.com> 20 de setembro de 2014 19:51

Para: Helena <helenapaix@gmail.com>, Teresa Cristina Cerqueira

Cco: Katia bordado <katiabordado50@gmail.com>

Olá Helena,

sou como as estações, rsrsrs faço contato de seis em seis meses, mais ou menos.

Kkk

Acho que agora a filha nasce: a tese. Estou com data prevista para outubro para qualificar a minha proposta de tese.

Estou fechando o referencial teórico e já desenhei a metodologia. Tem muito de mim nas escolhas. Assim que eu revisar a primeira versão com as correções da minha orientadora, te encaminho uma cópia para você ter a noção de como vou ler o seu blog e você como autora.

Já separei postagens do blog de 2008 até agora, buscando sempre aqueles nas quais você recebe comentários e compartilha vivências. Até tenho curiosidade de saber se você tem leitores assíduos e nomeados que de alguma forma fazem o blog 
ser escrito a muitas mãos. Caso haja me indique onde localizo estas postagens comentadas ou até mesmo se consigo contato com uma ou duas destas pessoas que são mais constantes contigo.

Se tudo correr como imagino, eu teria de dezembro a fevereiro para ouvir você, a autora. E se fosse possível um momento presencial com você para desenvolver uma conversa informal, sem caráter de entrevista, porque optei pela dinâmica da conversação para ouvi-la porque a subjetividade flui com mais liberdade.

Assim, gostaria de saber se é possível nesses meses que indiquei, você ter disponibilidade de agenda para esta conversa. Me desloco sem problemas maiores para sua cidade, e levarei comigo uma carta da minha orientadora e da universidade formalizando esse contato, como parte da minha pesquisa de doutorado. Sou aluna do programa de doutorado da Faculdade de Educação da Universidade de Brasília. Minha orientadora professora Doutora Teresa Cristina Siqueira Cerqueira que atua na linha de pesquisa sobre Subjetividade.

Desde já, gostaria de saber qual a forma de registro que a deixa mais à vontade? gravação em áudio, vídeo ou manuscrever a fala?

Assim dito, aguardo uma posição sua e copio para minha orientadora que nos lê em cópia.

Obrigada e felicidades nesta caminhada materna. Sou mãe de dois rapazes e sei que os anos iniciais são trabalhosos, mas imperdíveis.

Abraço carinhoso em você, em Del e nas crianças.

Rita

\section{Sempre grata}

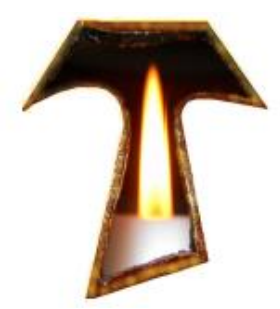

\section{Professora Rita de Cácia V M de Sousa \\ Contatos: 85532124 /33440091}

[Texto das mensagens anteriores oculto]

Rita Sousa <ritasousa122@gmail.com> 11 de novembro de 2014 12:34

Para: Helena Paix <helenapaix@gmail.com> 
reenviando

\section{Sempre grata}

07/03/2016 Gmail - Contando como andam os estudos do Sapatilhando

https://mail.google.com/mail/u/0/?ui=2\&ik=05c19f7fd0\&view=pt\&q=helenapaix\%40gmail.com $\& q s=$ true $\&$ search=query $\&$ th $=14 \ldots 3 / 4$

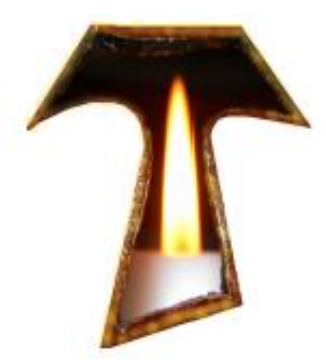

Professora Rita de Cácia V M de Sousa

Contatos: $85532124 / 33440091$

Mensagem encaminhada

De: Rita Sousa <ritasousa122@gmail.com>

Data: 20 de setembro de 2014 19:51

Assunto: Re: Contando como andam os estudos do Sapatilhando

Para: Helena <helenapaix@gmail.com>, Teresa Cristina Cerqueira

<teresacristinasc@gmail.com>

[Texto das mensagens anteriores oculto]

Helena <helenapaix@gmail.com> 14 de maio de 2015 09:59

Para: Rita Sousa <ritasousa122@gmail.com>

Bom dia, Rita.

Passei meses sem entrar neste email.

Logo, só vi seus emails hoje.

Espero que tenha corrido tudo bem.

Já finalizou?

Abs,

Lana/Helena.

| Nós nos tornamos mais autênticos quanto mais nos parecemos com o que sonhamos que somos | 
Almodóvar

http://sapatilhando.blogspot.com/

[Texto das mensagens anteriores oculto]

Rita Sousa <ritasousa122@gmail.com> 14 de maio de 2015 21:25

Para: Helena <helenapaix@gmail.com>

Olá Helena,

finalizo em dezembro. Mas já qualifiquei como pretendia. Agora estou na fase de construir a análise. Mas bons ventos a trouxeram. A minha banca gostou do trabalho e me orientou a trabalhar seu blog e seu avatar. Se é que posso caracterizar Helena desta forma. Portanto, não houve necessidade de entrevistar a pessoa real, a autora do material. Seu texto já se diz.

Obrigada pelo contato e assim que fechar e defender te envio uma cópia.

\section{Sempre grata}

\section{Professora Rita de Cácia V M de Sousa}

\section{Contatos: 85532124}

\section{/39013279}

"Aprendizagem não é uma reprodução objetiva de conteúdos dados É uma produção subjetiva que tem a marca do sujeito que aprende" (Rey, 2009)

https://mail.google.com/mail/u/0/?ui=2\&ik=05c19f7fd0\&view=pt\&q=helenapaix $\% 40 \mathrm{~g}$ mail.com\&qs=true \&search=query\&th $=14 \ldots 4 / 4$

07/03/2016 Gmail - Contando como andam os estudos do Sapatilhando

É uma produção subjetiva que tem a marca do sujeito que aprende" (Rey,2009)

[Texto das mensagens anteriores oculto]

Helena <helenapaix@gmail.com> 15 de maio de 2015 10:59

Para: Rita Sousa <ritasousa122@gmail.com>

Ô, Rita! Fico feliz! Estava preocupada de ter lhe prejudicado de alguma maneira!

Então fico aqui na torcida! E por favor não deixe de me enviar uma cópia mesmo, tá?

Meu outro email para caso você precise: Imanobrega@gmail.com 
Um abraço,

Lana.

| Nós nos tornamos mais autênticos quanto mais nos parecemos com o que sonhamos que somos |

Almodóvar

$\sim$ http://sapatilhando.blogspot.com/

[Texto das mensagens anteriores oculto] 


\section{Anexo 3 - Estudando sua obra (E-mail)}

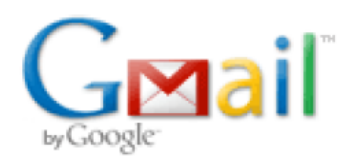

Rita Sousa <ritasousa122@gmail.com>

\section{Estudando sua obra}

3 mensagens

rita sousa <ritasousa122@gmail.com>

Para: helenapaix@gmail.com

\section{Oi Helena!}

Eu sou a Rita, mulher, mãe, amante e amada. Conheci seu site e o blog Sapatilhando. Sou professora e mestre em educação pela Universidade de Brasília e no momento estou participando do processo de seleção para o programa de doutorado da mesma universidade.

Pretendo me doutorar em Teoria Literária e para isso quero estudar sua obra digital, numa perspectiva feminina, feminista e literária. Sua narrativa tem uma ar de conversa, um toque de engajamento e uma poeticidade profunda.

Sua obra é pública, mas o processo de produção é particular. Assim, gostaria de saber da sua disponibilidade para alguns contatos com você para travarmos um diálogo sobre sua obra.

Segue meu currículo simplificado para que me conheça um pouco e também o link de um blog que estou ensaiando escrever com reflexões pessoais e outro voltado para meu trabalho como professora.

climaterioetereo.blogspot.com e profritadiscute.blogspot.com

Ora iê iê ô !

Exeu, Epá Babá, Axé!

Paz e Bem!

Rita de Cácia V. M. de Sousa

Fone: (61) 85532124

\section{CURRÍCULO SIMPLIFICADO RITA 2011.docx}

64K 
Helena <helenapaix@gmail.com>6 de julho de 2011 11:27

Para: rita sousa <ritasousa122@gmail.com>

Oi, Rita, tudo bem?

No momento estou em Buenos Aires visitando alguns amigos, mas me coloco a sua disposição para o que necessitar.

Por curiosidade: você já conversou com algum orientador no Doutorado que pretende? Interesso-me muito pelo mundo acadêmico, então, peço que, se possível, me mantenha informada do seu estudo, está bem?

Fico muito feliz de meus escritos terem gerado esse interesse em você.

Como o querido poeta Manoel de Barros diria: "A importância de uma coisa deve ser medida pelo encantamento que essa coisa produz em nós."

E esse encantamento com certeza é maior legado que alguém pode desejar.

No que eu puder ajudar, esteja certa de contar comigo.

Um grande abraço,

Helena.

| Nós nos tornamos mais autênticos quanto mais nos parecemos com o que sonhamos que somos |

Almodóvar

$\sim$ http://sapatilhando.blogspot.com/ 


\section{Anexo 4 - Sapatilhando e seus arquivos (E-Mail)}

\section{Sapatilhando e seus arquivos}

2 mensagens

rita sousa <ritasousa122@gmail.com>

Para: Adora do Mar <helenapaix@gmail.com>

16 de outubro de 2012 09:16

Oi Helena!

estou me organizando na coleta do material para minha tese de doutorado. O seu blog Sapatilhando é um dos três blogs que vou trabalhar e analisar na dimensão educativa e dialógica. Você teria como me ceder os arquivos das postagens? Um backup para que eu possa salvar em pdf e fazer a leitura do material?

"O que ocorrer com a Terra, recairá sobre os filhos da Terra.

Há uma ligação em tudo."

Portanto: "Os animais existem por suas próprias razões. Eles não foram feitos para humanos, assim como negros não foram feitos para brancos ou mulheres para os homens." (Alice Walker)

Paz e Bem!

Rita de Cácia V. M. de Sousa

Fone: (61) 85532124

Helena <helenapaix@gmail.com> 16 de outubro de 2012 13:36

Para: rita sousa <ritasousa122@gmail.com>

Oi, Rita, tudo bem?

Posso fazer isso sim. Só preciso de um tempinho porque já passei por três computares diferentes e o material, desde o começo do blog, está em backups diferentes. 
Além disso, neste momento, estou longe de casa: estou em Fortaleza, na casa dos meus pais, por conta de uma cirurgia cardíaca a que meu pai se submeterá.

Para quando você precisa?

É desde o começo do blog? Em 2008?

Os comentários não seriam importantes/relevantes para analisar a dimensão educativa e dialógica?

Porque se forem, acho que seria melhor ir em cada uma das postagens e imprimi-las com os comentários, não?

Bom, me diga, tá?

Estou à disposição.

Beijo,

Helena.

| Nós nos tornamos mais autênticos quanto mais nos parecemos com o que sonhamos que somos |

Almodóvar

http://sapatilhando.blogspot.com/

[Texto das mensagens anteriores oculto] 